\author{
UNIVERSIDADE DE SÃO PAULO \\ ESCOLA DE ENGENHARIA DE SÃO CARLOS
}

Fernanda Rodrigues Pinheiro

Avaliação dos efeitos tóxicos do tratamento de efluente doméstico por reator de leito fluidificado enriquecido com o anti-inflamatório diclofenaco em invertebrados aquáticos

São Carlos 

Fernanda Rodrigues Pinheiro

\title{
Avaliação dos efeitos tóxicos do tratamento de efluente doméstico por reator de leito fluidificado enriquecido com o anti-inflamatório diclofenaco em invertebrados aquáticos
}

Dissertação apresentada à Escola de Engenharia de São Carlos da Universidade de São Paulo, para obtenção do título de Mestre em Ciências - Programa de Pós-Graduação em Hidráulica e Saneamento.

Área de concentração: Hidráulica e Saneamento

Orientador: Prof. Dr. Juliano José Corbi

\section{VERSÃO CORRIGIDA}

\author{
São Carlos
}


AUTORIZO A REPRODUÇÃO TOTAL OU PARCIAL DESTE TRABALHO POR QUALQUER MEIO CONVENCIONAL OU ELETRONNICO, PARA FINS DE ESTUDO E PESQUISA, DESDE QUE CITADA A FONTE.

Ficha catalográfica elaborada pela Biblioteca Prof. Dr. Sérgio Rodrigues Fontes da EESC/USP com os dados inseridos pelo(a) autor(a).

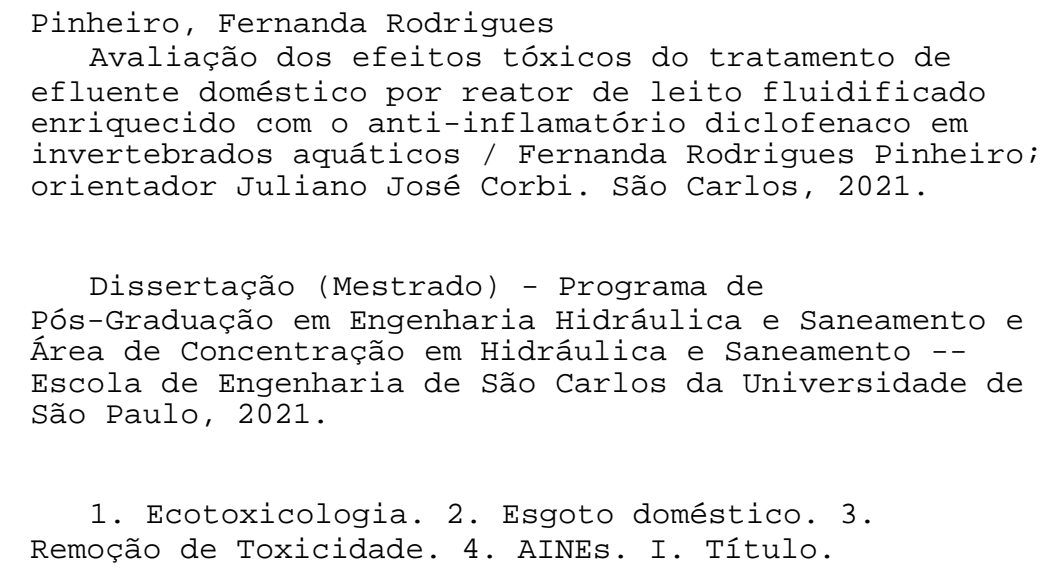

Eduardo Graziosi Silva - CRB - 8/8907 


\section{FOLHA DE JULGAMENTO}

Candidata: Engenheira FERNANDA RODRIGUES PINHEIRO.

Título da dissertação: "Avaliação dos efeitos tóxicos do tratamento de efluente doméstico por reator de leito fluidificado enriquecido com o anti-inflamatório diclofenaco em invertebrados aquáticos".

Data da defesa: 13/09/2021.

Comissão Julgadora

Prof. Associado Juliano José Corbi

(Orientador)

(Escola de Engenharia de São Carlos/EESC-USP)

Prof. Dr. Leonardo Rios

(Universidade de Araraquara/UNIARA)

Profa. Dra. Odete Rocha

(Universidade Federal de São Carlos/UFSCar)

Coordenador do Programa de Pós-Graduação em Engenharia Hidráulica e Saneamento:

Prof. Dr. Luiz Antonio Daniel

Presidente da Comissão de Pós-Graduação:

Prof. Titular Murilo Araujo Romero

\section{Resultado}

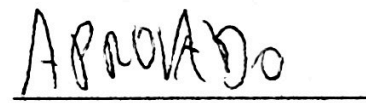





\section{AGRADECIMENTOS}

A Deus, pelo cuidado, providência e condução de cada momento, sempre surpreendendo e dispondo de graças maiores que o merecimento, através da intercessão de Nossa Senhora.

Ao meu esposo, Lucas Silva, e à minha querida irmã, Nathalia Pinheiro, família que não só me apoiou mas também trabalhou junto à mim na concnlusão e processamento desse documento, jamais esquecerei essa oferta de vida. Aos meus pais, Fátima e Adnilson, pelo apoio, amor incondicional, abnegações e sacríficios de tantos anos, para que eu tivesse condições e oportunidade de avançar na formação acadêmica, e chegasse à conclusão do curso de mestrado. Aos meus padrinhos, madrinhas, tios e familiares em geral por acreditarem em mim mais do que eu mesma.

Aos meus 9 companheiros Leaaenses desta batalha acadêmica que, em todos os momentos, me emprestaram disposição, ombro, dados, conselhos e experiência para lidar com os percalços da pesquisa. Agradeço, em especial, à Aline e Tallyson que montaram testes comigo, por disporem de seu tempo e paciência, sem vocês essa pesquisa jamais seria viável.

Ao meu orientador, professor Juliano Corbi, pelo conselho, suporte, paciência e dedicação ao longo desses dois anos de pesquisa - sua confiança, parceria e acolhimento foram fundamentais para o bom andamento de todo o curso. Agradeço também à parceria com a professora Maria Bernadete e a doutoranda Luciana Pirete, por compartilharem conhecimento, direcionamentos e me permitirem aprender um pouco mais sobre o universo dos reatores de tratamento de esgoto.

A todos os meus caros amigos, penso que se listasse cada um dos queridíssimos que fazem a minha vida mais leve, feliz e amável não caberiam em uma página, por isso, de maneira geral agradeço a todos que fazem parte dessa família, a minha estadia em São Carlos foi com certeza mais feliz por causa de todos vocês, que Deus os guardem e lhe recompensem pela dedicação e lealdade. À todos que de alguma forma colaboraram para que eu crescesse como profissional e principalmente como pessoa, obrigada por terem cruzado o meu caminho e me feito um ser humano melhor.

A USP, EESC e SHS pela oportunidade de crescer e contribuir com a comunidade acadêmica, e pelo apoio financeiro e confiança da FAPESP e CAPES. 

"Por vezes sentimos que aquilo que fazemos não é senão uma gota de água no mar. Mas o mar seria menor se lhe faltasse uma gota" Santa Teresa de Calcutá 



\section{RESUMO}

PINHEIRO, F. R. Avaliação dos efeitos tóxicos do tratamento de efluente doméstico por reator de leito fluidificado enriquecido com o anti-inflamatório diclofenaco em invertebrados aquáticos. 2021. 147p. Dissertação

(Mestrado) - Escola de Engenharia de São Carlos, Universidade de São Paulo, São Carlos, 2021.

A avaliação da toxicidade de efluentes é um relevante indicador da qualidade de tratamento de esgotos domésticos. O esgoto gerado nos centros urbanos é fonte de concentrada contaminação ambiental e veículo de substâncias utilizadas ou metabolizada pelo ser humano, entre elas, o anti-inflamatório Diclofenaco (DCF). Nesse trabalho, bioensaios foram aplicados na avaliação da eficiência do tratamento de efluentes domésticos por Reator Anaeróbio de Leito Fluidificado, bem como na investigação da toxicidade do DCF. Os invertebrados aquáticos Chironomus sancticaroli, Allonais inaequalis, Pristina longiseta e Ceriodaphnia silvestrii foram submetidos à amostras de afluente e efluente de diferentes configurações de operação do reator, em gradientes de diluições (de 100\% a $0,1 \%$ ), para avaliação do efeito agudo nos quatro organismos e crônico para o inseto C. sancticaroli. Os mesmos bioensaios foram realizados com o DCF em concentrações ambientais e extrapoladas $(100 \mathrm{mg} / \mathrm{L}$ a $100 \mu \mathrm{g} / \mathrm{L})$. A maior redução de toxicidade para $A$. inaequalis e P. longiseta foi observada na Fase I (13,00 e 8,33\%, respectivamente). Já para C. sancticaroli e C. silvestrii a maior redução da toxicidade ocorreu na Fase II e Fase III (19,46 e 22,91\%, respectivamente). Em exposições crônicas, o aumento proporcional de afluente e efluente induziu maiores danos ao desenvolvimento larval e deformidades no mentos de C. sancticaroli. O DCF apresentou toxicidade $\left(\mathrm{CE}_{50} \mathrm{e}^{\mathrm{CL}} \mathrm{L}_{50}\right)$ para $C$. sancticaroli, A. inaequalis, P. longiseta e C. silvestrii em escala de $\mathrm{mg} / \mathrm{L}(1,35 ; 68,41 ; 47,49 ; 26,43$, respectivamente). Em exposição subletal ao DCF, o C. sancticaroli sofreu alterações no comprimento larval e na formação dentária, com o aumento da concentração. Por meio dos resultados é possível perceber melhor qualidade de tratamentos para maiores TDHs e probabilidade de maior fonte de toxicidade atuante no sedimento da amostra. Os efeitos deletérios observados no ensaio com o diclofenaco, confirmam a necessidade de mapeamento desse fármaco bem como o desenvolvimento de tecnologias que o remova dos efluentes.

Palavras-chave: Ecotoxicologia. Esgoto doméstico. Remoção de Toxicidade. AINEs. 



\section{ABSTRACT}

PINHEIRO, F. R. Evaluation of the toxic effects of the treatment of domestic effluent by a fluidized bed reactor enriched with the anti-inflammatory diclofenac in aquatic macroinvertebrates. 2021. 147p. Dissertação (Mestrado) - Escola de Engenharia de São Carlos, Universidade de São Paulo, São Carlos, 2021.

The evaluation of the toxicity of effluents is an important indicator of the quality of treatment of domestic sewage. Effluents generated in urban centers is a source of concentrated environmental contamination and a vehicle for substances used or metabolized by humans, including the anti-inflammatory drug Diclofenac (DCF). In this work, the evaluation of the efficiency of the treatment of domestic effluents by Anaerobic Fluidized Bed Reactor, as well as the investigation of the toxicity of DCF alone, was carried out through bioassays. The aquatic invertebrates Chironomus sancticaroli, Allonais inaequalis, Pristina longiseta and Ceriodaphnia silvestrii were submitted to influent and effluent samples of different reactor operation configurations, in dilution gradients (from 100\% to 0.1\%), to evaluate the acute effect. in the four organisms and chronic for the insect $C$. sancticaroli. The same bioassays were performed with DCF at ambient and extrapolated concentrations $(100 \mathrm{mg} / \mathrm{L}$ to $100 \mu \mathrm{g} / \mathrm{L})$. The greatest reduction in toxicity for A. inaequalis and P. longiseta was observed in Phase I (13.00 and 8.33\%, respectively). As for C. sancticaroli and $C$. silvestrii, the greatest reduction in toxicity occurred in Phase II and Phase III (19.46 and $22.91 \%$, respectively). In chronic exposures, the proportional increase in influent and effluent induced greater damage to larval development and deformities in the chin of C. sancticaroli. DCF showed toxicity $\left(\mathrm{EC}_{50}\right.$ and $\left.\mathrm{LC}_{50}\right)$ for C. sancticaroli, A. inaequalis, P. longiseta and C. silvestrii in $\mathrm{mg} / \mathrm{L}$ scale $(1.35 ; 68.41 ; 47.49 ; 26.43$, respectively). In sublethal exposure to DCF, C. sancticaroli underwent changes in larval length and tooth formation, with increasing concentration. The results indicate better quality of treatments for higher TDHs and the probability of a greater source of toxicity acting on the sample's sediment. The deleterious effects observed in the trial with diclofenac confirm the need for mapping this drug as well as the development of technologies to remove it from effluents.

Keywords: Sewage ecotoxicology. Toxicity Removal. NSAIDs. 



\section{LISTA DE FIGURAS}

Figura 1 - Representação microscópica de C. silvestrii . . . . . . . . . . . . . . 32

Figura 2 - Registro microscópico da espécie Allonais inaequalis a)Visão geral de um indivíduo; b) prostomium; c) cerdas dorsais. . . . . . . . . . . . 34

Figura 3 - Registro microscópico da espécie Pristina longiseta a)Visão deral do indivíduo; b) Cerdas ventrais; c) cerdas aciculares unicúspides e cerdas capilares serrilhadas . . . . . . . . . . . . . . . . 35

Figura 4 - Ciclo de vida de Chironomus sancticaroli . . . . . . . . . . 36

Figura 5 - Representação molecular do Diclofenaco a) Estrutura química em 2D b) Estrutura em 3D . . . . . . . . . . . . . . . . . . . . . 4 47

Figura 6 - Cultivos mantidos no Laboratório de Ecologia de Ambientes Aquáticos; a) Chironomus sancticaroli; b) Allonais inaequalis; c) Ceriodaphnia silvestrii; d) Pristina longiseta . . . . . . . . . . . . . . . 56

Figura 7 - Esquema de montagem de teste de toxicidade aguda . . . . . . . . 59

Figura 8 - Testes de toxicidadde aguda realizados com os organismos-teste a) Chironomus sancticaroli; b) Pristina longiseta; c) Allonais inaequalis; d) Ceriodaphnia silvestrii. . . . . . . . . . . . . . . . . . . . . 60

Figura 9 - Teste de toxicidadde crônica utilizando o inseto aquático Chironomus sancticaroli . . . . . . . . . . . . . . . . . . . 61

Figura 10 - Ferramentas e registros obtidos por meio do teste de toxicidadde crônica realizado utilizando o inseto aquático Chironomus sancticaroli; a) larvas coletadas para a medição de comprimento; b) cápsula cefálica observada em microscópio e c) Microscópio utilizado com câmera conectada a computador ........................ 62

Figura 11 - Deformidades mais comuns encontradas no mentos de lavas de Chironomus sancticaroli; a) configuração normal; b) Vão de Köehn; c) dentes extras; d) ausência de dente; e) Sem dentes e f) dentes desgastados . . 63

Figura 12 - Desenho esquemático do RALF e pontos de coleta . . . . . . . . . . . . 64

Figura 13 - Registro fotográfico do RALF instalado na estação de tratamento . . . 65

Figura 14 - Exemplar de diluições aplicadas para a) afluente ao reator e b)efluente do reator . . . . . . . . . . . . . . . . . 66 66

Figura 15 - Resumo esquemático da abordagem metodológica utilizando amostras do RALF . . . . . . . . . . . . . . . . . . . . . 67

Figura 16 - Frasco usado para armazenamento da solução de diclofenaco . . . . . . 68

Figura 17 - Registro da configuração de teste de toxicidade crônica utilizando o diclofenaco . . . . . . . . . . . . . . . . . . 69

Figura 18 - Resumo esquemático da abordagem metodológica utilizando o diclofenaco 69 
Figura 19 - Resultado do teste de sensibilidade utilizando os organismo a) C. sancticaroli $(\mathrm{KCl})$; b) A. inaequalis $(\mathrm{KCl})$; c) C. silvestrii $(\mathrm{NaCl})$ e d) $P$. longiseta $(\mathrm{KCl}) \ldots \ldots \ldots \ldots 71$

Figura 20 - Resultado do teste toxicidade aguda utilizando A. inaequalis para a) o afluente ao reator e b) o efluente ao reator . . . . . . . . . . . 75

Figura 21 - Registro do comportamento de proteção apresentado por Allonais inaequalis em exposição a amostras do RALF. a) Aderência próxima ao espelho d'água e b) aderência acima do nível da água . . . . . . . . . 76

Figura 22 - Resultado do teste toxicidade aguda utilizando P. longiseta para a) o afluente ao reator e b) o efluente ao reator . . . . . . . . . . . 79

Figura 23 - Resultado do teste toxicidade aguda utilizando C. sancticaroli para a) o afluente ao reator e b) o efluente ao reator . . . . . . . . . . . . 81

Figura 24 - Registro do comportamento de proteção apresentado pelo inseto Chironomus sancticaroli em exposição a amostras do RALF. a) Criação de envoltório na superfície da água e b) criação de envoltório no sedimento 82

Figura 25 - Resultado do teste toxicidade aguda utilizando C. silvestrii para a) o afluente ao reator e b) o efluente ao reator . . . . . . . . . . . 84

Figura 26 - Curva de distribuição das espécies expoxtas a a) afluente da FI; b) efluente da FI; c) afluente da FII; d) efluente da FII; e) afluente FIII e f) efluente da FIII.

Figura 27 - Porcentagem de sobrevivência de larvas do inseto C. sancticroli submetidos a amostras do RALF após 10 dias de exposição . . . . . . . . . . 91

Figura 28 - Comprimento corporal das larvas do inseto C. sancticroli submetidos a amostras do RALF após 10 dias de exposição . . . . . . . . . . . . . 92

Figura 29 - Registro da morfologia bucal de exemplares de C. sancticaroli de cada tratamento do afluente do RALF . . . . . . . . . . . . . . . . . . 94

Figura 30 - Registro da morfologia bucal de exemplares de C. sancticaroli de cada tratamento do efluente do RALF . . . . . . . . . . . . . . . 95

Figura 31 - Número de deformidades bucais identificadas nas larvas de C. sancticaroli de cada tratamento do efluente do RALF . . . . . . . . . . . 96

Figura 32 - Deformidades identificadas em larvas submetidas a afluente e efluente do RALF. a) vão de Köehn; b) dentes faltando; c) dentes sobrando e d) dente desgastado . . . . . . . . . . . . . . . . . . . . . . 97

Figura 33 - Resultado do teste toxicidade aguda do diclofenaco utilizando os organismo a) P. longiseta e b)A. inaequalis . . . . . . . . . . . . . . 98

Figura 34 - Resultado do teste toxicidade aguda do diclofenaco utilizando C. silvestrii 100

Figura 35 - Resultado do teste toxicidade aguda do diclofenaco utilizando o inseto C. sancticaroli . . . . . . . . . . . . . . . . . . . . 102 
Figura 36 - Curva de discribuição da sensibilidade das espécies aquáticas à exposição

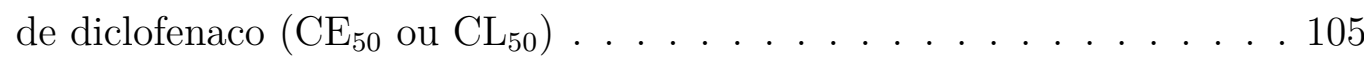

Figura 37 - Porcentagem de sobrevivência de larvas do inseto C. sancticroli submetidos ao diclofenaco após 10 dias de exposição) . . . . . . . . . . . . 106

Figura 38 - Comprimento corporal das larvas do inseto C. sancticroli submetidos ao diclofenaco após 11 dias de exposição . . . . . . . . . . . . . . . 107

Figura 39 - Registro da morfologia bucal de exemplares de C. sancticaroli de cada tratamento da exposição ao diclofenaco . . . . . . . . . . . . . . . . . 109

Figura 40 - Número de deformidades bucais identificadas nas larvas de $C$. sancticaroli em cada tratamento utilizando o diclofenaco . . . . . . . . . . . . 110

Figura 41 - Deformidades identificadas em larvas submetidas ao diclofenaco.a) vão de Köehn; b) dentes faltando; c) dentes sobrando e d) dente desgastado 111

Figura 42 - Parâmetros físico-químicos F1 . . . . . . . . . . . . . . . . . 139

Figura 43 - Parâmetros físico-químicos F2 . . . . . . . . . . . . . . . . . . 141

Figura 44 - Parâmetros físico-químicos F3 . . . . . . . . . . . . . . . . . . . 143

Figura 45 - Parâmetros físico-químicos F1 . . . . . . . . . . . . . . . . . . 145

Figura 46 - Parâmetros físico-químicos DCF . . . . . . . . . . . . . . 147 



\section{LISTA DE TABELAS}

Tabela 1 - Aplicações de bioensaios em amostras de efluentes . . . . . . . . . . . . 41

Tabela 2 - Grupos e fármacos com maior concentração nos corpos hídricos . . . . 44

Tabela 3 - Concentração máxima do diclofenaco encontrada em corpos hídricos . . 47

Tabela 4 - Toxicidade aguda do diclofenaco aos organismos aquáticos (CL50 e CE50) 49

Tabela 5 - Toxicidade crônica do diclofenaco aos organismos aquáticos . . . . . . 51

Tabela 6 - Condições de cultivo mantidas no Laboratório de Ecologia de Ambientes Aquáticos . . . . . . . . . . . . . . . . . . 5 55

Tabela 7 - Composição e parâmetros utilizados para a realização dos testes de sensibilidade . . . . . . . . . . . . . . . . 57

Tabela 8 - Composição e parâmetros utilizados para a realização dos testes de toxicidade aguda . . . . . . . . . . . . . . . . . . . . 58

Tabela 9 - Composição e parâmetros utilizados para a realização dos testes de toxicidade crônica. . . . . . . . . . . . . . . . . . . . . . 61

Tabela 10 - Operação e configuração do RALF . . . . . . . . . . . . . . . . . 64

Tabela 11 - Frações de afluente e efluente aplicadas nos testes . . . . . . . . . . . . 65

Tabela 12 - Gradiente de concentrações aplicados para os testes de toxicidade aguda utilizadno o diclofenaco . . . . . . . . . . . . . . . . . . 68

Tabela 13 - Parâmetros medidos para amostras de afluente e efluente de cada fase . 73

Tabela 14 - Parâmetros medidos ao início dos bioensaios para cada fase de operação do reator . . . . . . . . . . . . . . . . . . . 74

Tabela 15 - Faixa de valores dos parâmetros medidos para as concentrações de diclofenaco . . . . . . . . . . . . . . . . . . . . 74

Tabela 16 - Faixa de valores dos parâmetros medidos para os bioensaios utilizando os organismos bentônicos em amostras do RALF . . . . . . . . . . . . 77

Tabela 17 - Valores dos $\mathrm{CL}_{50}$ para A. inaequalis submetido a amostras do RALF e os valores de Remoção de Toxicidade (RT) dado em pontos percentuais

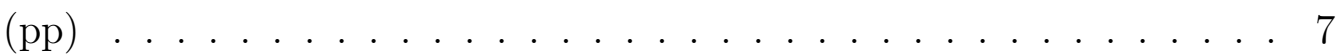

Tabela 18 - Valores dos $\mathrm{CL}_{50}$ para P. longiseta submetido a amostras do RALF e os valores de Remoção de Toxicidade (RT) expressos em pontos percentuais

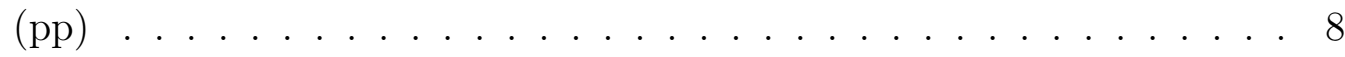

Tabela 19 - Valores dos CL $_{50}$ para C. sancticaroli submetido a amostras do RALF e os valores de Remoção de Toxicidade (RT) dado em pontos percentuais

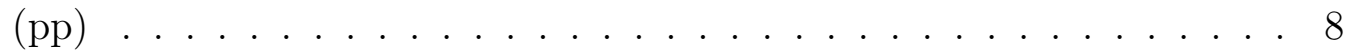

Tabela 20 - Faixa de valores dos parâmetros medidos para os bioensaios utilizando Ceriodaphnia silvestrii em amostras do RALF . . . . . . . . . . . . . . 85 
Tabela 21 - Valores dos $\mathrm{CE}_{50}$ para $C$. silvestrii submetida a amostras do RALF e os valores de Remoção de Toxicidade (RT) dado em pontos percentuais (pp) . . . . . . . . . . . . . . . . . 86

Tabela 22 - Proporção ou fração de efluente permitido em corpos receptores de Águas Doces classes 2 e 3 com base nos ensaios de toxiciade aguda . . 90

Tabela 23 - Faixa de valores dos parâmetros medidos para os bioensaios utilizando os organismos A. inaequalis e P. longiseta em exposição ao DCF .. . 99

Tabela 24 - Faixa de valores dos parâmetros medidos para os bioensaios utilizando a C. silvestrii em exposição ao DCF . . . . . . . . . . . . . . . . . . . 101

Tabela 25 - Faixa de valores dos parâmetros do teste utilizando o inseto C. sancticaroli em exposição ao DCF . . . . . . . . . . . . . . . . . . . . 103 


\section{LISTA DE ABREVIATURAS E SIGLAS}

\begin{tabular}{ll} 
ABNT & Associação Brasileira de Normas Técnicas \\
LEAA & Laboratório de Ecologia de Ambientes Aquáticos \\
CONAMA & Conselho Nacional do Meio Ambiente \\
RALF & Reator de Leito Fluidificado \\
USP & Universidade de São Paulo \\
LPB & Laboratório de Processos Biológicos \\
DCF & Diclofenaco \\
USEPA & United States Environmental Protection Agency \\
WET & Whole Effluent Toxicity \\
TIE & Toxicity Identification Evaluation \\
ETE & Estação de Tratamento de Esgoto \\
CEx & Concentração de Efeito em x\% dos organismos \\
CLx & Concentração Letal a x\% dos organismos \\
CEO & Concentração de Efeito Observado \\
CENO & Concentração de Efeito Não Observado \\
CAPES & Coordenação de Aperfeiçoamento de Pessoal de Nível Superior \\
CECR & Concentração do Efluente no Corpo Receptor \\
\hline &
\end{tabular}



SUMÁRIO

INTRODUÇÃo $\ldots \ldots \ldots \ldots \ldots \ldots \ldots$

HIPÓTESE E OBJETIVOS . . . . . . . . . . . . . . . 27

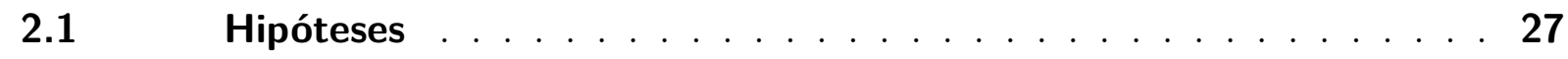

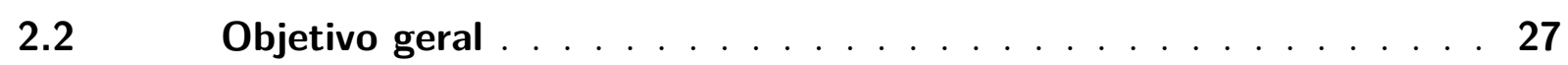

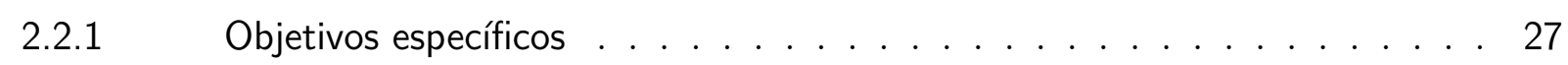

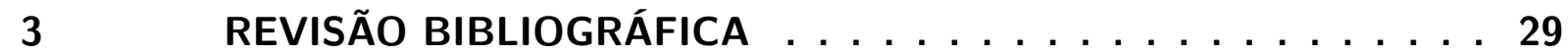

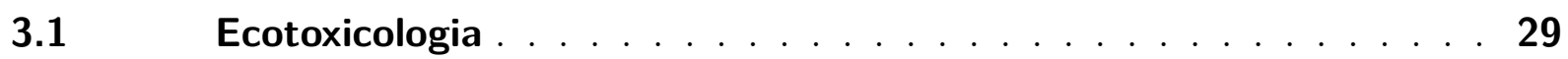

3.1.1 Fundamentos da ecotoxicologia aquática . . . . . . . . . . . . . . 29

3.1.2 Seleção de organismos-teste . . . . . . . . . . . . . . . 30

3.1.3 Representantes locais da biota aquática . . . . . . . . . . . . . . 31

3.1.3.1 Ceriodaphnia silvestrii . . . . . . . . . . . . . . . 31

3.1.3.2 Allonais inaequalis e Pristina longiseta . . . . . . . . . . . . . . 33

3.1.3.3 Chironomus sancticaroli . . . . . . . . . . . . . . . . . . . 34

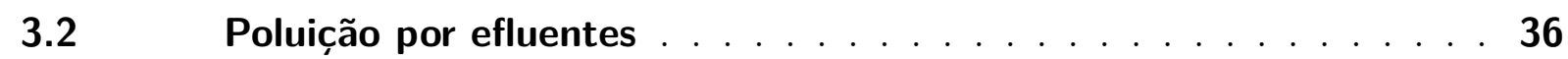

3.2.1 Efluentes e sua dispersão . . . . . . . . . . . . . . . . 36

3.2.2 Tecnologias de tratamento de efluentes e seus enfoques . . . . . . . . . 37

3.2.3 Normas sobre a toxicidade de efluentes . . . . . . . . . . . . . . 38

3.2.4 Aplicação dos testes de toxicidade dos efluentes . . . . . . . . . . . . 40

$3.3 \quad$ Emergência de fármacos no meio ambiente . . . . . . . . . 43

3.3.1 Fármacos e sua dispersão no meio ambiente . . . . . . . . . . . 43

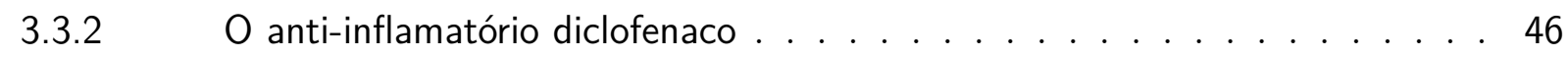

3.3.3 Toxicidade do Diclofenaco . . . . . . . . . . . . . . . . . . . . . 49

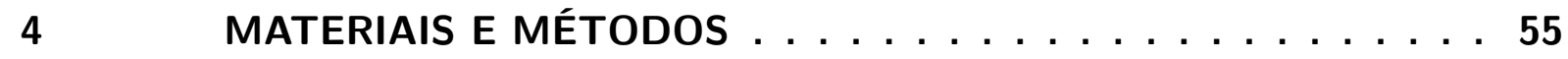

$4.1 \quad$ Cultivo e manutenção das espécies . . . . . . . . . . . 55

$4.2 \quad$ Testes de sensibilidade . . . . . . . . . . . . . 57

$4.3 \quad$ Testes de toxicidade aguda . . . . . . . . . . . 58

$4.4 \quad$ Testes de toxicidade crônica $\ldots \ldots \ldots \ldots \ldots$

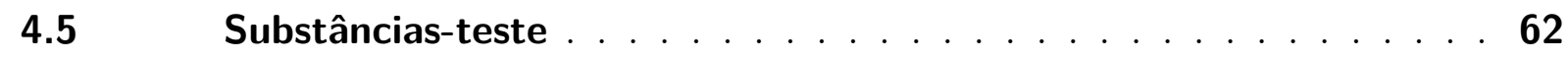

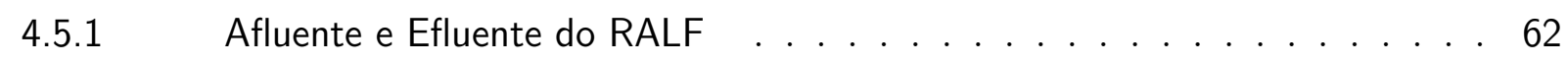

4.5.2 Diclofenaco de Potássio . . . . . . . . . . . . . . . 67

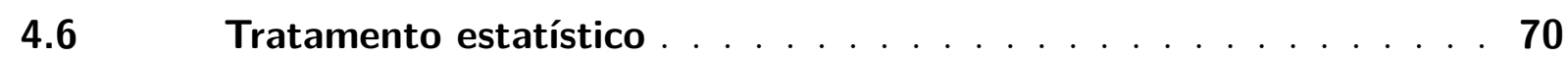

5 RESULTADOS E DISCUSSÕES $\ldots \ldots \ldots \ldots \ldots \ldots$

$5.1 \quad$ Teste de sensibilidade $\ldots \ldots \ldots \ldots \ldots \ldots \ldots$ 
$5.2 \quad$ Características dos Contaminante-alvo . . . . . . . . . . 72

5.2.1 Afluente e efluente do RALF . . . . . . . . . . . . . . . . 72

$5.2 .2 \quad$ Diclofenaco . . . . . . . . . . . . . . . . . . . 74

$5.3 \quad$ Teste de toxicidade aguda das amostras do RALF . . . . . . . . . 75

5.3.1 Allonais inaequalis . . . . . . . . . . . . . . . 75

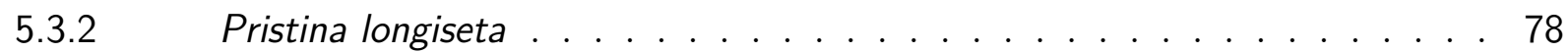

5.3.3 Chironomus sancticaroli . . . . . . . . . . . . . . . . . 80

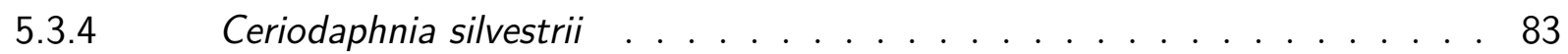

5.3.5 Comparação entre espécies . . . . . . . . . . . . . . . . . . . 86

$5.4 \quad$ Teste de toxicidade crônica das amostras do RALF . . . . . . . . . . 91

5.4.1 Sobrevivência . . . . . . . . . . . . . . . . . . 91

5.4.2 Comprimento larval . . . . . . . . . . . . . . . 92

$5.4 .3 \quad$ Deformidades bucais . . . . . . . . . . . . . . . . 93

5.5 Toxicidade Aguda do Diclofenaco . . . . . . . . . . . . . . 97

5.5.1 Toxicidade para o Allonais inaequalis e a Pristina longiseta . . . . . . . . . 97

5.5.2 Toxicidade para Ceriodaphnia silvestrii . . . . . . . . . . . . . . 100

5.5.3 Toxicidade para Chironomus sancticaroli . . . . . . . . . . . . . . . . 102

$5.5 .4 \quad$ Comparação entre espécies . . . . . . . . . . . . . . . . . 103

5.6 Toxicidade crônica do Diclofenaco (Chironomus sancticaroli) . . . . 106

$5.6 .1 \quad$ Sobrevivência . . . . . . . . . . . . . . . . . . . 106

5.6.2 Comprimento larval . . . . . . . . . . . . . . . . . . 107

$5.6 .3 \quad$ Deformidades bucais . . . . . . . . . . . . . . . 108

$5.7 \quad$ Considerações finais . . . . . . . . . . . . . . . . 111

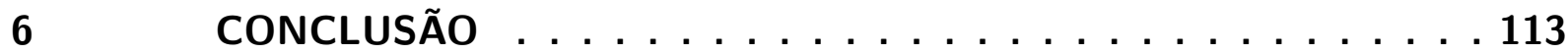

REFERÊNCIAS . . . . . . . . . . . . . . 115

APÊNDICES

APÊNDICE A - PARÂMETROS FÍSICO-QUÍMICOS FASE 1 - TESTE AGUDO . . . . . . . . . . . . . 139

APÊNDICE B - PARÂMETROS FÍSICO-QUÍMICOS FASE 2 - TESTE AGUDO ..................... 141

APÊNDICE C - PARÂMETROS FÍSICO-QUÍMICOS FASE 3 - TESTE AGUDO . . . . . . . . . . . . . . 143 
APÊNDICE D - PARÂMETROS FÍSICO-QUÍMICOS FASE 1 - TESTE

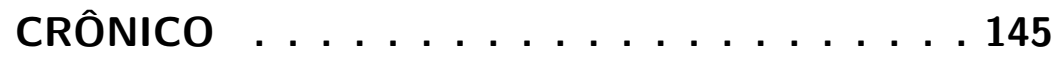

APÊNDICE E - PARÂMETROS FÍSICO-QUÍMICOS TESTES UTI-

LIZANDO O DICLOFENACO . . . . . . . 147 



\section{INTRODUÇÃO}

O crescente consumo hídrico nas diversas atividades humanas, gera alteração nas características físicas, químicas e biológicas da água, tornando-a foco concentrado de contaminação, potencial veículo de transmissão de doenças (MARA, 2013) e forte agente tóxico para a biota aquática (MAGDEBURG; STALTER; OEHLMANN, 2012; SILVA et al., 2021a). Ainda que as técnicas de tratamento de efluentes estejam em constante progresso, o efluente descartado pelas estações de tratamento de esgotos pode permanecer com características tóxicas à comunidade aquática (MARZIO et al., 2005; RA et al., 2008; MAGDEBURG et al., 2014). Longe de ser uma perturbação de repercussão apenas local, devido ao reuso indireto do esgoto e à processos de bioacumulação e biomagnificação, os compostos recalcitrantes dos efluentes domésticos continuam disponíveis para a contaminação humana e ambiental (CREWS; GORE, 2011).

Os fármacos, amplamente detectados em águas residuárias (COUTO; LANGE; AMARAL, 2019), são potenciais agentes tóxicos do meio aquático devido à sua concepção ser desenvolvida para alcançar alta eficiência em pequenas doses (SANTOS et al., 2010). Dentre os fármacos presentes no esgoto doméstico o diclofenaco (DCF), um anti-inflamatório não esteroidais (AINE`s), é largamente prescrito por médicos e ministrado em hospitais, chegando a apresentar concentrações de $836 \mu \mathrm{g} / \mathrm{L}$ em efluentes (ASHFAQ et al., 2017) e $116 \mu \mathrm{g} / \mathrm{L}$ em águas superficiais (HANIF et al., 2020). Os efeitos deletérios do DCF à biota aquática são conhecidos internacionalmente no meio científico (LONAPPAN et al., 2016; OLIVEIRA et al., 2018; MATEJCZYK et al., 2020), o conhecimento da repercussão dessa toxicidade nos corpos hídricos tropicais e em escala local é importante no estabelecimento de limites aceitáveis em cada região e estimular tecnologias de tratamento que reduzam essas concentrações.

Novas tecnologias de tratamento vêm sendo estudadas com a finalidade de tornar possível a eficiência de tratamento a substâncias específicas, como os fármacos e outras substâncias recalcitrantes (RODRIGUEZ-NARVAEZ et al., 2017). Nesse contexto, o reator de leito fluidificado é uma alternativa tecnológica de remoção de compostos persistentes (CRUZ-MORATÓ et al., 2013; ANDRADE et al., 2017), alternando-se tempos de detenção hidráulico, substratos e composições que melhor se adequem aos objetivos do tratamento. Um importante parâmetro a ser considerado na seleção das melhores configurações de tratamento é a toxicidade final do efluente, uma vez que a remoção de determinados compostos possa exigir a adição de métodos ou substâncias que tornem o efluente ainda mais tóxico (KLAMERTH et al., 2010; RIZZO, 2011; MAGDEBURG et al., 2014), não justificando a alternativa selecionada.

Os organismos utilizados em testes ecotoxicológicos são dos mais variados habitats 
e níveis tróficos, como plantas, algas, vertebrados e invertebrados (BERTHET, 2015). O grupo dos invertebrados aquáticos se caracterizam por uma ampla biodiversidade e variabilidade taxonômica, possuem papel fundamental no equilíbrio da cadeia trófica e são de conhecido acervo científico sobre seu comportamento, fisiologia e variação genética (CHAUMOT et al., 2014), tornando-os organismos de boa representatividade na avaliação de impactos à biota. Considerando-se a climatografia típica da região de São Carlos (SP) e a importante função ecológica dos invertebrados, quatro espécies foram selecionadas como organismos-teste na avaliação de impactos de efluentes do RALF nos corpos receptores e da presença do fármaco diclofenaco em concentrações letais e subletais. Os resultados visam promover conhecimento sobre a eficiência na remoção de agentes tóxicos através do RALF e a importância da remoção de substâncias, como o DCF, para a mitigação de impactos ambientais.

Esta pesquisa contribui para o desenvolvimento do Projeto Temático FAPESP $n^{\circ}$ 2015/06246-7, “Aplicação do Conceito de Biorrefinaria a Estações de Tratamento Biológico de Águas Residuárias: O Controle da Poluição Ambiental Aliado à Recuperação de Matéria e Energia", desenvolvido em parceria com Laboratório de Processos Biológicos (LPB) da Escola de Engenharia de São Carlos (EESC) e o Laboratório de Ecologia e Ambientes Aquáticos (LEAA) da mesma escola, afim de gerar equilíbrio entre seleção de alternativas de tratamento de esgoto e melhoria da qualidade de vida de e organismos aquáticos. 


\section{HIPÓTESE E OBJETIVOS}

\subsection{Hipóteses}

- Hipótese 1: O Reator Leito Fluidificado (RALF), em escala piloto, possibilita diferentes eficiências na redução de toxicidade à biota aquática, com relação aos efluentes domésticos, para cada configuração de teste aplicada;

- Hipótese 2: O anti-inflamatório Diclofenaco (DCF) apresenta efeito adverso à biota aquática em concentrações encontradas no meio ambiente.

\subsection{Objetivo geral}

Avaliar a toxicidade aguda e crônica do afluente e efluente do RALF utilizando quatro invertebrados aquáticos, em diversas fases de operação do reator, e realizar esses mesmos ensaios utilizando o fármaco Diclofenaco isoladamente.

\subsubsection{Objetivos específicos}

- Avaliar os potenciais danos à sobrevivência dos invertebrados aquáticos Chironomus sancticaroli, Allonais inaequalis, Pristina longiseta e Ceriodaphnia silvestrii em diferentes fases e diluições de afluente e efluente do RALF, em curto período de exposição;

- Identificar concentrações letais do fármaco Diclofenaco de Potássio nos invertebrados aquáticos Chironomus sancticaroli, Allonais inaequalis, Pristina longiseta e Ceriodaphnia silvestrii, em curto período de exposição;

- Avaliar potenciais modificações no comprimento larval e deformidades bucais das larvas do inseto Chironomus sancticaroli quando expostas ao efluente e afluente do RALF, em diferentes diluições de uma fase, em longo período de exposição;

- Avaliar potenciais modificações no comprimento larval e deformidades bucais das larvas do inseto Chironomus sancticaroli quando expostas a diferentes gradientes de concentração de Diclofenaco, em longo período de exposição. 



\section{REVISÃO BIBLIOGRÁFICA}

\subsection{Ecotoxicologia}

A ecotoxicologia é a ciência desenvolvida para compreender os efeitos dos agentes naturais e antrópicos nas comunidades e seus representantes (NEWMAN, 2019; ZHOU et al., 2018). É cientificamente reconhecido que as respostas biológicas são melhores ferramentas para prever o comportamento dos estressores em relação aos ecossistemas, aliadas a análises físicas e químicas (ZAGHLOUL et al., 2020).

A ecotoxicologia tem raiz na toxicologia, seus primeiros registros documentados em 1816 quando pesquisou-se os efeitos adversos de substâncias tóxicas em insetos aquáticos (JR; JR, 1993). O termo ecotoxicolgia foi oficialmente registrado em 1969 pelo toxicologista René Truhaut (TRUHAUT, 1977) como o estudo dos efeitos de substâncias, naturais ou sintéticas, em organismos vivos de diversos níveis tróficos, desde então ela vem ganhando reconhecimento no meio científico como uma importante ferramenta de biomonitoramento da qualidade do meio ambiente de estudo (AMIARD-TRIQUET; AMIARD; MOUNEYRAC, 2015; HÄDER, 2018).

\subsubsection{Fundamentos da ecotoxicologia aquática}

Na ecotoxicologia aquática são estudadas as iterações entre o meio aquoso ou seu sedimento e os organismos desse habitat, uma vez compreendido que os ecossistemas aquáticos são os principais pontos de destinação de contaminação antropogênica (AMIARDTRIQUET; AMIARD; MOUNEYRAC, 2015). Costa et al. (2008) afirma que as análises químicas em corpos hídricos são importantes na identificação e quantificação das substâncias tóxicas enquanto os testes de toxicidade são importantes na avaliação do efeito dessas substâncias em sistemas biológicos. A ecotoxicologia aquática, portanto, surge como um novo parâmetro de avaliação da qualidade das águas, sendo inserido como exigência ambiental de órgãos internacionais e nacionais e permitindo inferências sobre impactos ecossitêmicos (MAGALHÃES; FILHO et al., 2008).

A ecotoxicologia estuda um apanhado de respostas de níveis moleculares e genéticas a comunitárias e até ecossistêmicas através de diferentes metodologias, a fim de compreender as reações específicas dos organismos à agentes tóxicos ou as alterações no contexto de todo o habitat (FATH, 2018). Ao longo dos últimos anos de atuação, essa ciência avançou na investigação de respostas biológicas cada vez mais detalhadas, sendo a mortalidade a resposta base para a verificação de efeitos extremos de agentes tóxicos em curtos períodos de exposição para a população de uma espécie e um resultado muito utilizado no Brasil (KRULL; BARROS, 2012) . As respostas obtidas em ensaios com populações podem ser 
de curta ou longa duração.

A partir das observações de curta duração, avalia-se a letalidade dos agentes tóxicos sendo possível calcular as concentrações ou proporções de substâncias que causam a morte ou imobilidade a $50 \%$ da população submetida a teste $\left(\mathrm{CE}_{50}\right.$ ou $\left.\mathrm{CL}_{50}\right)$, bem como a Concentração de Efeito Não Observado (CENO), que corresponde a maior concentração avaliada no estudo que não apresenta nenhum efeito deletério ao organismo exposto ou ainda a Concentração de Efeito Observado (CEO), que seria a menor concentração na qual algum efeito deletério foi identificado (ZAGATTO; BERTOLETTI et al., 2008). As respostas obtidas em ensaios de longa duração com populações são mais variadas, podendo ser repostas de alteração na reprodução, no comportamento, mutações, deformidades, atraso ou aceleração nos processos biológicos entre outros (ROSENBAUM, 2015). Os tipos de respostas dependem da espécie submetida a teste, por isso, um maior número de espécie de diferentes habitats e níveis tróficos dão informação mais completa sobre os efeitos das substâncias para a biota aquática.

\subsubsection{Seleção de organismos-teste}

Os organismos aquáticos utilizados em testes ecotoxicológicos são dos mais variados habitats e níveis tróficos, como plantas, algas, invertebrados e vertebrados (BERTHET, 2015). A seleção do organismo a ser avaliado precisa levar em consideração a sua relevância ecológica e/ou sua correspondência com a específica hipótese levantada, a metodologia aplicada deve apresentar a forma de cultivo, a fonte de captura dos indivíduos além dos detalhes observados principalmente no tratamento controle (HANSON et al., 2017).

O grupo dos invertebrados aquáticos se caracterizam por uma ampla biodiversidade, grande variabilidade taxonômica, possuem papel fundamental no equilíbrio da cadeia trófica e são de conhecido acervo científico sobre seu comportamento, fisiologia e variação genética (CHAUMOT et al., 2014). O largo uso desse grupo como organismo-teste em bioensaios é fundamentado na sua abrangente distribuição ao redor do mundo, sensibilidade à poluentes, custo-benefício de manutenção e cultivo acessíveis e alta taxa de reprodução (CATTANEO et al., 2009), ademais, para a aplicação desses organismos em testes de toxicidade no Brasil não é exigida aprovação do comitê de ética (OLIVEIRA; GOLDIM, 2014), o que facilita sua utilização no país.

Dependendo da função do organismo no meio aquático, esse organismo pode ser mais ou menos sensível a determinado contaminante presente no meio aquático (CASTILLO; VILA; NEILD, 2000; BARAN; TARNAWSKI, 2015). Para organismos filtrantes (p.e. Daphnia magna, Ceriodaphnia silvestrii, etc.), normalmente substâncias voláteis, sólidos suspensos e outros contaminantes em maior concentração na coluna d'água são mais tóxicos e, se presentes na composição do efluente, podem elevar a toxicidade da amostra total (HYNE R. V., 1993; CHERRY et al., 2005; ZOCCHI; SOMMARUGA, 2019). Já 
organismos de habitat bentônicos (p.e. Chironomus spp., Pristina longiseta, etc.) costumam ser mais sensíveis a substâncias de maior densidade que água e sólidos sedimentáveis, como é o caso de alguns dos metais pesados e do lodo gerado em processos de tratamento e decantados no sedimento (ANTUNES et al., 2007; SIZMUR et al., 2019; STEYN et al., 2019). Devido a essas diferentes respostas, mesmo de organismos do mesmo nível trófico, é importante para a avaliação mais detalhada de toxicidade de substâncias com mais de uma espécie de hábitos diferentes.

\subsubsection{Representantes locais da biota aquática}

Além das vantagens no uso de invertebrados aquáticos em bioensaios supracitadas, a seleção de espécies para testes deve levar e consideração a ocorrência local do agente tóxico estudado. Diferentes climatologias, pressões atmosféricas e regime pluviométrico podem alterar a diversidade da cadeia trófica nos diversos biomas ao redor do mundo (HELMUTH et al., 2010; IBANEZ et al., 2018; GILLESPIE; RODERICK, 2014), selecionar uma espécie que seja naturalmente presente na região estudada subsidia uma análise real dos riscos da persistência de contaminantes nos corpos receptores locais. Entre as culturas mantidas no Laboratório de Ecologia de Ambientes Aquáticos (LEAA) da Escola de Engenharia de São Carlos (EESC-USP), estão quatro invertebrados representantes da biota aquática São Carlense, são eles o microcrustáceo Ceriodaphnia silvestrii, os Oligoquetos Allonais inaequalis e Pristina longiseta e o inseto Chironomus sancticroli. Algumas características e aplicações na ecotoxicologia são abordadas nos tópicos subsequentes.

\subsubsection{Ceriodaphnia silvestrii}

Os microscrustáceos aquáticos são o grupo de organismos-teste mais antigos e amplamente utilizados em ensaios ecotoxicológicos ao redor do mundo (MOUNT; NORBERG, 1984) e demonstram alta sensibilidade a agentes tóxicos (GUTIERREZ; GAGNETEN; PAGGI, 2012; SILVA et al., 2020a). Ceriodaphnia silvestrii (Daday, 1902) é um microcrustáceo representante dos ecossistemas de água doce brasileiros, padronizado para testes de toxicidade crônica pela Associação Brasileira de Normas Técnicas (ABNT - ASSOCIAÇÃO BRASILEIRA DE NORMAS TÉCNICAS, 2016), o que o coloca como organismo-teste muito utilizado no Brasil e indicado para a avaliação de impactos ambientais em alguns órgãos ambientais do estado de São Paulo (BERTOLETTI, 2008).

A espécie C. silvestrii foi primeiramente descrita pelo pesquisador Daday em 1902, é uma espécie de fácil diferenciação entre as demais espécies da mesma família devido a estrutura cervical acentuada, olhos ocupando quase toda a parte anterior da cabeça e uma garra com um pecten (FONSECA; ROCHA, 2004), um exemplar apresentado por Abreu et al. (2010) pode ser observado na Figura 1.

Ceriodaphnia silvestrii apresenta larga distribuição geográfica ao longo da América 
Figura 1 - Representação microscópica de C. silvestrii
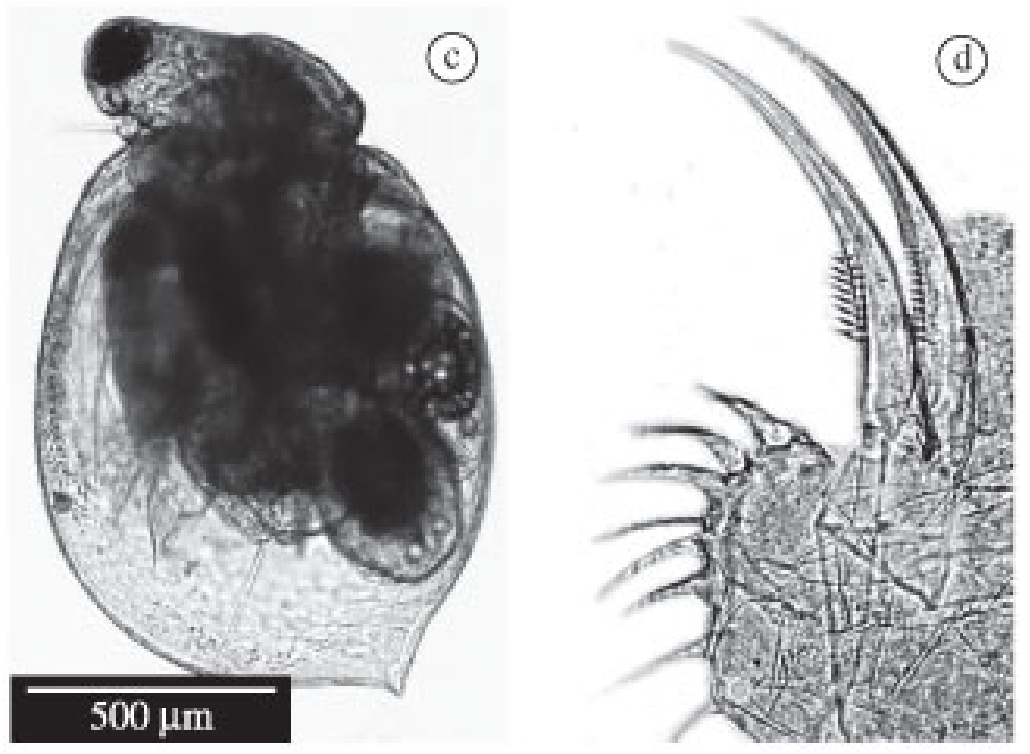

Fonte: Abreu et al. (2010)

do Sul, encontrada facilmente em ambientes com maior concentração de matéria orgânica, grande abundância, facilidade no cultivo, curto ciclo de vida, em torno de 29 dias, e rápida e numerosa reprodução assexuada, formando clones com baixa diferenciação genética (FONSECA; ROCHA, 2004) que são dependentes de fatores como a disponibilidade de alimento e parâmetros físico-químicos do ambiente (ROSE; WARNE; LIM, 2000). As duas últimas características conferem a esse organismo a possibilidade de obtenção de respostas em testes de toxicidade crônica em menor tempo, se comparado a outros indivíduos da família Daphnidae, como a cladocera Daphnia magna (BRENNAN et al., 2006; ABNT ASSOCIAÇÃO BRASILEIRA DE NORMAS TÉCNICAS, 2017)).

Nos últimos anos, algumas pesquisas vem utilizando $C$ silvestrii em ensaios de toxicidade aguda, aplicando-se os mesmos princípios do teste com outras cladóceras e observaram boa sensibilidade do organismo à contaminação aquática (MOREIRA et al., 2014; MANSANO et al., 2018a; SILVA et al., 2020b). Essa sensibilidade pode estar relacionada ao hábito alimentar de filtração da água, que expõe esse organismo à contaminação de partículas em suspensão e outras susbtâncias mais presentes na coluna d'água, como já exposto em tópicos anteriores (subseção 3.1.2). Enquanto consumidor primário, os organimos planctônicos como a cladocera $C$. silvestrii tem papel estratégico na ciclagem de nutrientes, bem como em processos de bioconcentração e biomagnificação de contaminantes para organismos de níveis tróficos superiores (TAO et al., 2017), por esta razão o estudo dos efeitos da poluição antrópica nesse grupo é de importância vital na previsão do impacto da persistência de substâncias tóxicas no meio aquático. 


\subsubsection{Allonais inaequalis e Pristina longiseta}

As oligoquetas aquáticas são organismos de abundante presença nos ambientes lênticos e lóticos, são comumente encontradas associadas a raízes e folhas de plantas quáticas, sedimento e locais de maior disponibilidade de alimento (ALVES; GORNI, 2007; GORNI; ALVES, 2008). A família dos Naididae, no qual ambos os vermes Allonais inaequalis (Stephenson, 1911) e Pristina longiseta (Ehrenberg, 1828) estão inseridos, são diferenciados dos demais grupos dos oligochaeta, pela vida mais ativa, vivendo numa região superficial do sedimento, com alguns representantes de natação livre na coluna d'água, todos os organismos posuem mecanismos de reprodução assexuada por fissão partaômica, e em alguns casos, reprodução sexuada com órgãos reprodutores em regiões mais anteriores do seu comprimento se comparado a outras famílias (ERSÉUS, 2005).

A. inaequalis é uma das espécies de Naididae que possuem mecanismos de natação bem desenvolvido (FELIPE et al., 2020), o que permite maior abrangência na captura de alimeto, propagação no ambiente, e contato com partículas e iterações biológicas do habitat bentônico e da coluna d'água. Os organismos dessa espécie são hermafroditas, possuem tamanhos que variam de 3 a $9 \mathrm{~mm}$ (37 a 85 segmentos), sem pigmentação em seu tecido externo e nem olhos (ERSÉUS, 2005; CORBI; GORNI; CORREA, 2015), o registro fotgráfico da espécie foi fieta por (CORBI; GORNI; CORREA, 2015) pode ser observado na Figura 2.

Pristina longiseta é uma espécie da família Naididae que quase não possui natação livre, sendo registrada predominantemente no habitat bentônico (CASTRO et al., 2020). O comprimento dos idivíduos dessa espécie variam de 2 a 4 mm (ZATTARA; BELY, 2011), sendo portanto menores que a espécie $A$. Inaequalis, associadas a essa característica, a menor movimentação natacional, a pigmentação avermelhada no tecido externo, mais evidente nos organismos com mais idade (ÖZPOLAT et al., 2016), marcam a diferença entre as duas espécies em observações com microscópio estereoscópio. Essa espécie possui reprodução sexuada e assexuada, por fissão, o que é mais comum no cultivo laboratorial de populações de Pristina longiseta (ÖZPOLAT et al., 2016). O registro do organismo geral é apresentado na Figura 3.

A aplicação da espécie $A$. Inaequalis em ensaios ecotoxicológicos do meio líquido vem ganhando mais ressonância no Brasil nos últimos anos em especial, pela contribuição do Laboratório de Ecologia de Ambientes Aquáticos (LEAA) e parceiros (CORBI; GORNI; CORREA, 2015; ROCHA et al., 2018; CASTRO et al., 2020). O utilização de P. Longiseta como organismo-teste na ecotoxicologia aquática foi sugerido por Smith et al. (1991) primeiramente, e recentemente atualizado em estudos realizados no LEAA, apresentando satisfatória sensibilidade a susbtâncias de referência utilizadas internacionalmente (CASTRO et al., 2020). Esses macroinvertebrados são importantes bioindicadores de efeitos adversos a agentes tóxicos, por sua posição na cadeia trófica, sensibilidade a contaminan- 
Figura 2 - Registro microscópico da espécie Allonais inaequalis a)Visão geral de um indivíduo; b) prostomium; c) cerdas dorsais.

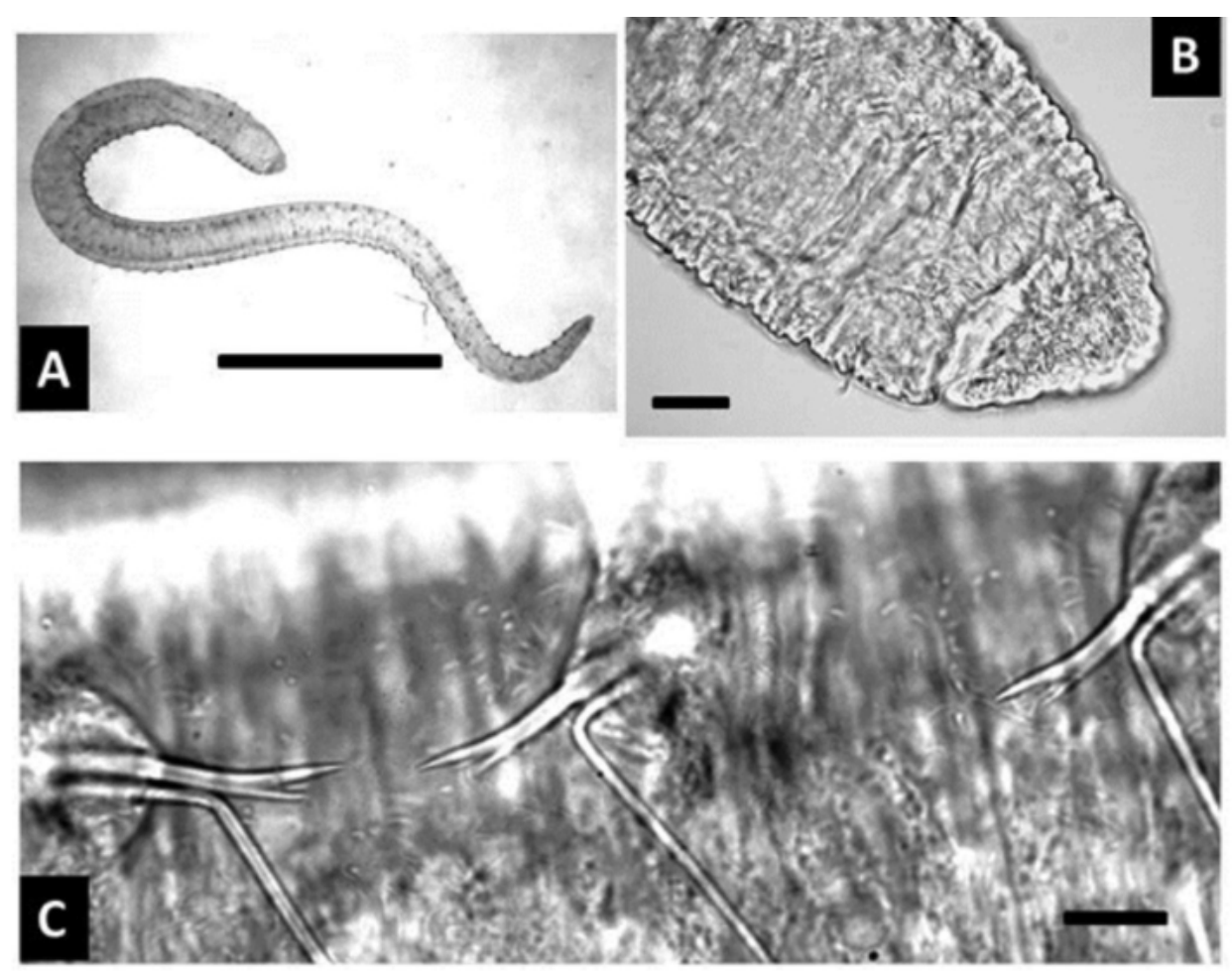

Fonte: Corbi, Gorni e Correa (2015)

tes específicos e certa tolerância à poluição, até por serem comumente encontrados em ambientes eutrofizados (CASTRO et al., 2020; FELIPE et al., 2020).

\subsubsection{Chironomus sancticaroli}

A família Chironomidae é a mais comum habitante dos ambientes aquáticos de água doce, sendo encontrada em todos os continentes do mundo, de regiões de clima quente a regiões glaciais (FERRINGTON, 2007). As larvas de Chironomidae se alimentam de matéria orgânica, bactérias e outras partículas em suspensão disponíveis ao seu entorno (BEGHELLI et al., 2018; TRIVINHO-STRIXINO, 2011). Segundo Porinchu e MacDonald (2003), esse grupo de insetos possui posição chave na cadeia trófica das comunidades (entre produtores primários e consumidores secundários) e sua cápsula cefálica composta de quitina permite boa preservação morfológica e facilidade de detecção nos sedimentos.

O inseto Chironomus sancticaroli (Strixino e Strixino,1981) tem ciclo de vida holometábolo, passando por fase ogívera, larval e de pupa, em meio aquático, e posterior emergência de adultos alados, que se reproduzem e ovopositam na água, fechando seu ciclo (TRIVINHO-STRIXINO, 1980), conforme ilustrado na Figura 4. Larvas de Chironomussp. são comumente observadas de ambientes eutróficos a ambientes oligotróficos, sendo re- 
Figura 3 - Registro microscópico da espécie Pristina longiseta a)Visão deral do indivíduo; b) Cerdas ventrais; c) cerdas aciculares unicúspides e cerdas capilares serrilhadas

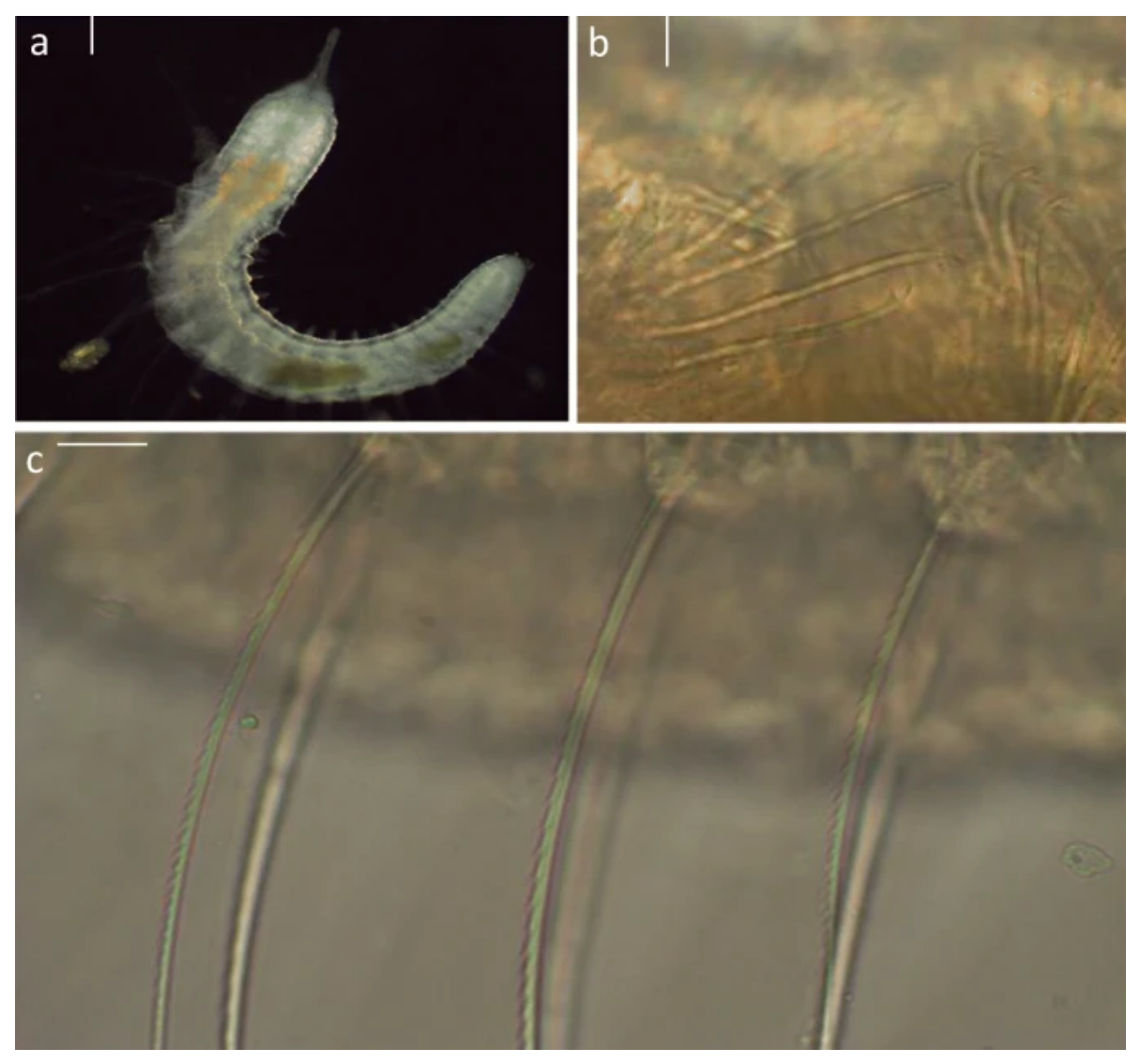

Fonte: Castro et al. (2020)

portada sua presença em estações de tratamento de esgoto (QUINTANA et al., 2018) e corpos receptores impactados por efluentes domésticos (POSSETTI, 2015) demonstrando sua resistência a impactos ambientais.

O invertebrado bentônico de água doce $C$. sancticaroli vem sendo utilizado amplamente como organismo-teste em ensaios ecotoxicológicos nos últimos anos (MORAIS et al., 2014; RICHARDI et al., 2015; PALACIO-CORTÉS et al., 2017; BERNEGOSSI et al., 2019; PINTO et al., 2021b; ALBUQUERQUE et al., 2021). A seleção desse organismo se justifica, entre outras razões, pela sensibilidade e número de respostas expressas ao ser exposto a contaminantes ou amostras ambientais, como perda de variabilidade genética (COLOMBO-CORBI et al., 2017), alteração na atividade enzimática (REBECHIBAGGIO et al., 2016) ou redução da fecundidade potencial medida pelo comprimento das asas (TRIVINHO-STRIXINO, 1980), além de outras variáveis observadas comumente em organismos dessa família (YOUBI et al., 2020). 
Figura 4 - Ciclo de vida de Chironomus sancticaroli

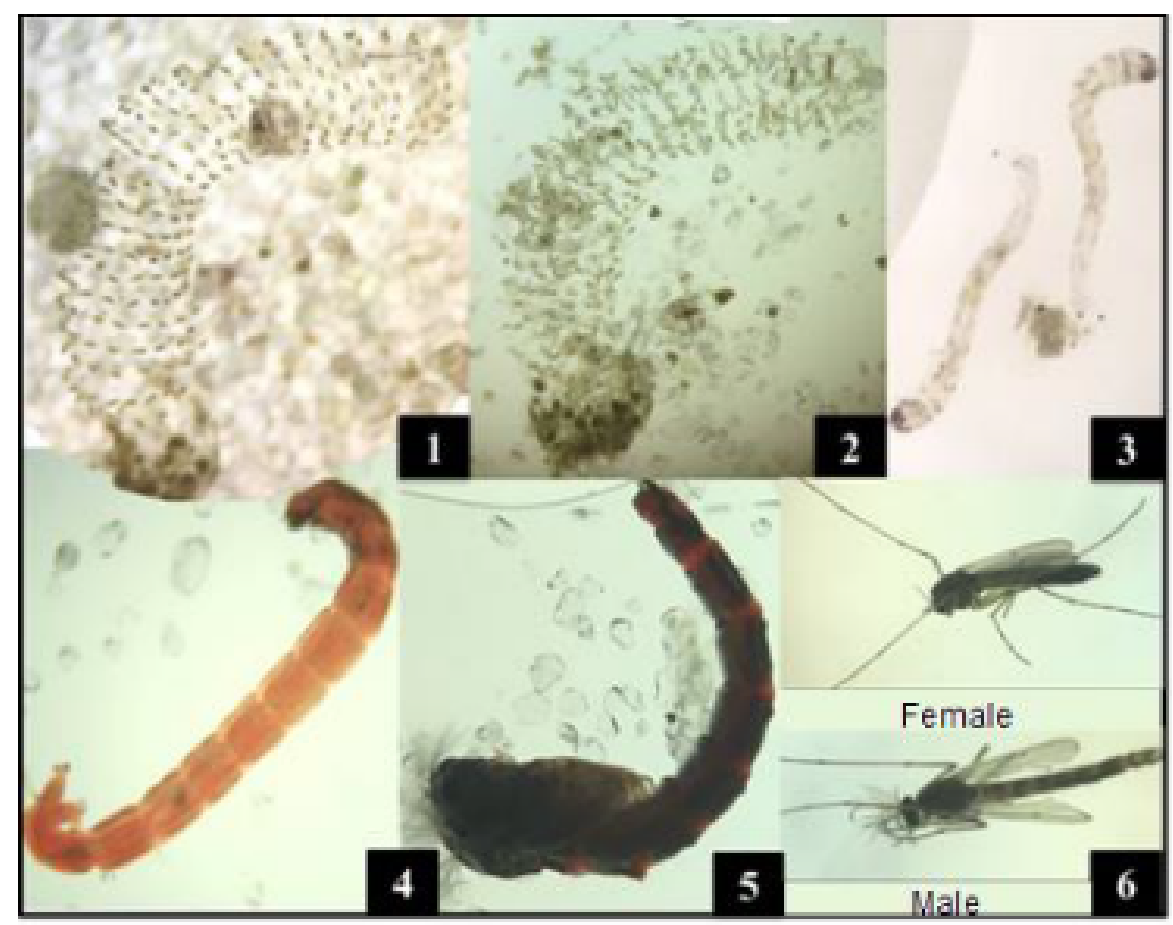

Fonte: Corbi, Gorni e Correa (2015)

\subsection{Poluição por efluentes}

\subsubsection{Efluentes e sua dispersão}

A produção e dispersão de efluentes, sejam ele de origem industrial ou doméstica, é uma preocupação interncional em países de todos os níveis sociais, uma vez que estima-se que $80 \%$ das águas residuárias no mundo retornam aos corpos hídricos sem nenhuma forma de remoção de agentes tóxicos (ONU - ORGANIZAÇÃO DAS NAÇÕES UNIDAS, 2020). Através de processos de reutilização, percolação, lixiviação e consumo indireto de água, é esperado que essa contaminação alcance as águas de abastecimentos e retornem para o acesso fácil e corriqueiro da sociedade, causando vários tipos de infecções e doenças de veiculação hídrica (REHMAN; KHAN; MUHAMMAD, 2020; PARUCH; PARUCH; SøRHEIM, 2020; PITTER et al., 2020).

No Brasil, esse cenário é exposto por pesquisas realizadas pela Agência Nacional das Águas (ANA), que revelam que dos 9,1 toneladas de esgoto gerados diariamente no país cerca de $18,7 \%$ é coletado sem direcionamento para tratmento, e cerca de $26,4 \%$ não é nem coletado, sendo lançados diretamente nos corpos hídricos, o que representa cerca de $45 \%$ do esgoto (4,1 ton) in natura são despejados todos os dias em rios e mares brasileiros (ANA - AGÊNCIA NACIONAL DAS ÁGUAS, 2017). Por essa razão, e confirmando os resultados obtidos por Mushtaq et al. (2020), a poluição por efluentes, principalmente os 
domésticos, está entre a mais recorrente fonte de degradação da qualidade ambiental.

Como consequência dessa degradação da qualidade da água, existe um crescente aumento na demanda de investimentos em processos cada vez mais avançados de tratamento para o abastecimento público (SANTANA; ZHANG; MIHELCIC, 2014; GHERNAOUT, 2017; LIU et al., 2017a) que ainda enfetram obstáculos na implantação de tecnologias efetivas para a remoção total de substâncias recalcitrantes, principalmente para localidades subdesenvolvidas (DOSU et al., 2021; MURRAY et al., 2020; SIWILA; BRINK, 2020). Outro custo atrelado à degadação ambiental causada pela poluição por efluentes é o investimento público em programas de saúde direcionados para o atendimento de pacientes acometidos por doenças de veiculação hídrica ou ainda milhares de mortes ocasioanadas pela falta de saneamento (WATSON, 2006; SIQUEIRA et al., 2017; GOVENDER; BARNES; PIEPER, 2011).

A heterogeneidade e flutuação na composição dos esgotos sanitários leva a uma dificuldade na definição de um tratamento ideal, sendo característico de cada região ou cidade no Brasil, de acordo com as características do seu esgoto e qualidade do corpo receptor, discutir a tecnologia de tratamento mais adequada (BRASIL, 2011). De qualquer forma, a complexidade da constituição dos esgotos domésticos, com misturas de compostos derivados de dejetos humanos, infiltração de escoamentos pluvial, conexões indiretas, resíduos líquidos hospitalares, fármacos, lavagem de oficinas, laboratórios, restaurantes, entre outros fazem dessa amostra uma concentrada fonte de prejuízos a fauna e flora aquática (MARZIO et al., 2005; RA et al., 2008; MAGDEBURG; STALTER; OEHLMANN, 2012).

Várias caracterizações dos compostos presentes nos esgotos realizadas ao longo dos anos indicam a presença de inúmeras substâncias, como metais pesados, nutrientes, microrganismos, matéria orgânica e inorgânica, assim como materiais radioativos e micropoluentes emergentes de várias fontes (GROSS, 2005; HENZE; COMEAU, 2008; GOGOI et al., 2018; OUDA et al., 2020). O tratamento visando a diminuição da toxicidade dos efluentes é o primeiro passo na mitigação dos impactos antrópicos sobre o meio ambiente e consequentemente, na melhoria da qualidade de vida humana.

\subsubsection{Tecnologias de tratamento de efluentes e seus enfoques}

As operações de tratamento de efluentes ocorrem através de processos físicos, químicos e biológicos, que são organizados, seja simultaneamente numa mesma etapa, seja intercambiada, com a finalidade de remover poluentes específicos, como carga orgânica, nutrientes e sólidos suspensos e dissolvidos (METCALF; EDDY; TCHOBANOGLOUS, 1991). No entanto, um novo enfoque tem sido levantado para a melhoria na retenção de alguns contaminantes emergentes, como metais pesados, hormônios, surfactantes, fármacos entre outros (ACERO et al., 2010; AVISAR et al., 2010; CHO; HUANG; SCHWAB, 2011; 
MELO-GUIMARÃES et al., 2013).

Entre tecnologias investigadas para a remoção de novos contaminantes destaca-se o estudo de tecnologias de mudança de fase do contaminante, tratamentos biológicos e processos oxidativos avançados (RODRIGUEZ-NARVAEZ et al., 2017). Em processos biológicos, de funcionamento aeróbio ou anaeróbio, é possível a obtenção de bons resultados no tratamento de compostos recalcitrantes (ZWIENER; FRIMMEL, 2003; QUINTANA et al., 2018). Os reatores de lodos ativados foram os mais estudados (CLARA et al., 2005; ROSAL et al., 2010; GHERNAOUT; ELBOUGHDIRI, 2019), no entanto, há evidências de um potencial êxito na remoção de fármacos por parte de reatores de leito móvel e fluidificado (JEWELL et al., 2016; LANCHEROS et al., 2019), tornando-o um relevante objeto de estudo na área de tratamento de contaminantes emergentes.

O reator de leito fluidificado é uma tecnologia de tratamento que utiliza de biomassa aderida ao meio suporte inerte (leito fluidificado. ex.: areia), que se mantêm suspensa no meio devido ao fluxo ascendente do afluente e do volume recirculado (CAMPOS; PEREIRA et al., 1999). O tratamento para metabolizar matéria orgânica, nitratos e outros compostos se dá pela digestão dos microrganismos ligados ao biofilme, que no reator de leito fluidificado possuem maior área de contato com a massa líquida por que toda a superfície dos grãos está exposta ao meio aquoso (HICKMAN; DEGENSTEIN; RIBEIRO, 2016).

No Laboratório de Processos Biológicos (LPB) já foram estudados diferentes modelos e configurações do RALF, em escala de bancada (FREIRE, 2005; MOTTERAN, 2013), escala aumentada (MACEDO, 2019) e escala piloto (GEROSA, ). Por último, em parceria com o Serviço Autônomo de Água e Esgoto São Carlos (SAAE), um reator anaeróbio de leito fluidificado (escala piloto) foi estudado na Estação de Tratamento de Esgoto de São Carlos (ETE Monjolinho) com o efluente doméstico real da cidade após processos primários de tratamento, com o objetivo de observar a eficiência na remoção de dois fármacos, Diclofenaco e Ibuprofeno, dentro do projeto FAPESP $\mathrm{n}^{\mathrm{O}}$ 2015/06246-7, “Aplicação do Conceito de Biorrefinaria a Estações de Tratamento Biológico de Águas Residuárias: O Controle da Poluição Ambiental Aliado à Recuperação de Matéria e Energia", no quais, além da busca da eficiência tecnológica, busca-se o controle da contaminação ambiental e conhecimento dos impactos dessas tecnologias à comunidade aquática.

\subsubsection{Normas sobre a toxicidade de efluentes}

A ecotoxicologia se faz necessária na avaliação de amostras ambientais quando se compreende que apenas análises físico-químicas não são suficientes para estimar o impacto ambiental de substâncias (POMPÊO et al., 2015). A avaliação da toxicidade dos efluentes, para as normas internacionais, normalmente tem o objetivo de determinar limites 
de toxicidade permitidos para o despejo de efluentes nos corpos d'água (LIBRALATO; ANNAMARIA; FRANCESCO, 2010). Diferentes diretrizes internacionais podem ser aplicadas na investigação ecotoxicológicas de despejos residuárias, para avaliar de forma integral amostras de efluentes, a aplicação do Whole Effluent Toxicity (WET) ou avaliação da toxicidade total do efluente é uma ferramenta útil.

O WET foi sugerido pela Agência de Proteção Ambiental dos Estados Unidos (USEPA) com o objetivo de mapear a presença de agentes tóxicos e controlar a qualidade aquática (REGULATIONS, 1991). Nesse método, os ensaios com as amostras de efluentes brutos, sem modificações, são submetidas a gradientes de diluição com água de cultivo, e os testes de toxicidade utilizando organismos padronizados pela agência, são realizados sem a determinação dos constituintes da massa líquida, objetivando a proteção à biota aquática.

Concomitantemente ao método do WET, também foi estabelecido pela USEPA o método que busca a causa da toxicidade em amostras de efluentes, o TIE (Toxicity Identification Evaluation) ou AIT (Avaliação de Identificação da Toxicidade), (MOUNT, 1988). O TIE tem como principal objetivo a identificação do(s) composto(s), parâmetro(s) ou substância(s) que causam a toxicidade da amostra. Nesse método é imprescindível a identificação da composição amostral para a correta análise do teste.

O TIE é composto por 3 etapas, uma de caracterização, outra de identificação e a última de confirmação (Fases I, II e III, respectivamente). Na Fase I investiga-se a natureza do agente tóxico por meio de processos de filtração, aeração, adição de álcoois, sais, ácidos e bases. A toxicidade avaliada no TIE pode ser a toxicidade aguda ou crônica e um teste é realizado para cada alteração feita na amostra. A Fase II se caracteriza pela identificação dos contaminantes que estão em concentrações mais prejudiciais aos organismos testados, com outra sequência de manipulações baseando-se nos resultados obtidos na Fase I. Na Fase III os compostos identificados anteriormente são isolados e expostos aos organismos-teste para a confirmação da toxicidade observada nas fases anteriores (NORBERG-KING et al., 1991).

No âmbito nacional a avaliação de qualidade dos despejos de estações de tratamento de esgoto, a investigação da toxicidade de efluentes vem sendo um parâmetro exigido pelos órgãos ambientais, principalmente através da Resolução CONAMA 430/2011. Essa Lei, na Seção sobre Condições e Padrões de Lançamento de Efluentes (Seção II), artigo 18, define que o efluente não poderá ter ação tóxica a nenhum organismo presente no meio aquático do corpo receptor, sendo de responsabilidade de órgãos ambientais competentes o estabelecimento dos limites de toxicidade (BRASIL, 2011).

A Companhia Ambiental do Estado de São Paulo (CETESB) é a autoridade estadual responsável por estabelecer critérios adicionais para a avaliação da toxicidade de efluentes, essa, por sua vez, acatou o sugerido pela Resolução CONAMA 430/2011 nos 
seguintes termos:

I - para efluentes lançados em corpos receptores de água doce Classes 1 e 2, e águas salinas e salobras Classe 1, a Concentração do Efluente no Corpo Receptor (CECR) deve ser menor ou igual à Concentração de Efeito Não Observado (CENO) de pelo menos dois níveis tróficos [...]; II - para efluentes lançados em corpos receptores de água doce Classe 3, e águas salinas e salobras Classe 2, a Concentração do Efluente no Corpo Receptor (CECR) deve ser menor ou igual à concentração que não causa efeito agudo aos organismos aquáticos de pelo menos dois níveis tróficos [...].§ 50 Nos corpos de água em que as condições e padrões de qualidade previstos na Resolução $n^{\circ} 357$, de 2005 , não incluam restrições de toxicidade a organismos aquáticos não se aplicam os parágrafos anteriores. (BRASIL, 2011).

Por essa determinação se faz necessário o uso de diluições em diferentes porcentagens para a verificação de concentrações de efluente permitidos no corpo receptor. As famílias, classes ou espécies de organismos sugeridos pela CETESB são aqueles de metodologia estabelecida pela Associação Brasileira de Normas Técnicas (ABNT): Vibrio fischeri, Daphnia spp., Ceriodaphnia spp., Chlorophyceae e Cyprinidae, correspondendo às NBR $15.411,12.713,13.373,12.648$ e 15.088 respectivamente.

\subsubsection{Aplicação dos testes de toxicidade dos efluentes}

Os primeiros registros da aplicação dos testes de toxicidade em amostra de esgoto foram publicados por Hicks e DeWitt (1971) para avaliar a toxicidade de amostras de efluentes de fábrica de celulose, marcando os primeiros passos da preocupação científica com os impactos da contaminação de efluentes na biota aquática. Uma vez ressaltado a necessidade a ecotoxicologia vem sendo utilizada, além de parâmetro adicional na avaliação de eficiência do tratamento, como ferramenta de monitoramento ambiental (WORKAGEGN et al., 2013; MOLYNEUX; STEC; HULL, 2014; ROUX et al., 2017; GHOLAMI-BORUJENI; NEJATZADEH-BARANDOZI; AGHDASI, 2018; TUFAIL et al., 2020).

A Tabela 1 exemplifica algumas aplicações dos testes de toxicidade de efluentes para fins de biomonitoramento ou ferramenta paralela na avaliação de eficiência de tratamento, com resultados significativos na escolha de tecnologias e estabelecimento de limites de concentração de efluentes em corpos receptores para diferentes tipos de efluentes. 
Tabela 1 - Aplicações de bioensaios em amostras de efluentes

\begin{tabular}{|c|c|c|c|c|c|}
\hline $\begin{array}{l}\text { Tipo } \\
\text { de eflu- } \\
\text { ente }\end{array}$ & $\begin{array}{l}\text { Organismo- } \\
\text { teste }\end{array}$ & $\begin{array}{l}\text { Efeito obser- } \\
\text { vado }\end{array}$ & $\begin{array}{l}\text { Resultado/ Fra- } \\
\text { ção de efeito } \\
(\%)\end{array}$ & $\begin{array}{l}\text { Obje- } \\
\text { tivo }\end{array}$ & Referência \\
\hline Doméstico & $\begin{array}{l}\text { Tripneustes gra- } \\
\text { tilla }\end{array}$ & $\begin{array}{l}\text { Fertilização de } \\
\text { ovos }\end{array}$ & $\begin{array}{l}\text { Lodo ativado eli- } \\
\text { minou a toxici- } \\
\text { dade do efluente }\end{array}$ & $\mathrm{BM}$ & $\begin{array}{l}\text { Vazquez } \\
(2013)\end{array}$ \\
\hline Doméstico & $\begin{array}{l}\text { Pseudokirchne- } \\
\text { riella subcapi- } \\
\text { tata }\end{array}$ & $\begin{array}{l}\text { Inibição de den- } \\
\text { sidade celular } \\
\left(\mathrm{IC}_{25}\right)\end{array}$ & $50,4 \%-86,6 \%$ & $\mathrm{BM}$ & $\begin{array}{l}\text { Naddy et } \\
\text { al. }(2011)\end{array}$ \\
\hline Doméstico & $\begin{array}{l}\text { Pseudokirchne- } \\
\text { riella subca- } \\
\text { pitata, Cerio- } \\
\text { daphnia dúbia e } \\
\text { Danio rerio }\end{array}$ & $\begin{array}{l}\text { Inibição de } \\
\text { crescimento, } \\
\text { reprodução e } \\
\text { ovos fertiliza- } \\
\text { dos (CENO) }\end{array}$ & $\begin{array}{l}\approx 11,7 \%, 40 \% \text { e } \\
66,5 \%, \text { respectiva- } \\
\text { mente }\end{array}$ & $\mathrm{BM}$ & $\begin{array}{l}\text { Kusui, } \\
\text { Itatsu e } \\
\text { Jin (2017) }\end{array}$ \\
\hline Doméstico & $\begin{array}{l}\text { Lemna minor, } \\
\text { Lumbriculus } \\
\text { variegatus, } \\
\text { Chironomus } \\
\text { riparius e } \\
\text { Daphnia magna }\end{array}$ & $\begin{array}{l}\text { Efeitos crôni- } \\
\text { cos: inibição } \\
\text { de crescimento, } \\
\text { reprodução e } \\
\text { etc. }\end{array}$ & $\begin{array}{l}\text { Surgimento de } \\
\text { subprodutos } \\
\text { tóxicos após } \\
\text { ozonização }\end{array}$ & $\mathrm{ET}$ & $\begin{array}{l}\text { Magdeburg, } \\
\text { Stalter e } \\
\text { Oehlmann } \\
(2012)\end{array}$ \\
\hline $\begin{array}{l}\text { Doméstico } \\
\text { (vários) }\end{array}$ & $\begin{array}{l}\text { Scenedesmus } \\
\text { obliquus }\end{array}$ & $\begin{array}{l}\text { Letalidade, den- } \\
\text { sidade celular, } \\
\text { clorofila-A, es- } \\
\text { tresse oxidativo } \\
\text { e integridade } \\
\text { da membrana } \\
\text { celular }\end{array}$ & $\begin{array}{l}\text { Desinfecção com } \\
\text { NaClO foi mais tó- } \\
\text { xica e lodos ativa- } \\
\text { dos e reator de ba- } \\
\text { telada sequencial } \\
\text { melhoram toxici- } \\
\text { dade }\end{array}$ & $\begin{array}{l}\mathrm{ET} \mathrm{e} \\
\mathrm{BM}\end{array}$ & $\begin{array}{l}\text { Zhang et al. } \\
\text { (2015) }\end{array}$ \\
\hline Hospitalar & $\begin{array}{l}\text { Chlorella vulga- } \\
\text { ris }\end{array}$ & $\begin{array}{l}\text { Inibidor de cres- } \\
\text { cimento }\end{array}$ & $\begin{array}{l}\text { Ozonização foi a } \\
\text { melhor tecnogia } \\
\text { de desinfecção }\end{array}$ & $\mathrm{ET}$ & $\begin{array}{l}\text { Luo et al. } \\
(2020)\end{array}$ \\
\hline
\end{tabular}

(BM): Biomonitoramento

(ET): Eficiência de Tecnologia 
Tabela 1 - Aplicações de bioensaios em amostras de efluentes

\begin{tabular}{|c|c|c|c|c|c|}
\hline $\begin{array}{l}\text { Tipo } \\
\text { de eflu- } \\
\text { ente }\end{array}$ & $\begin{array}{l}\text { Organismo- } \\
\text { teste }\end{array}$ & $\begin{array}{l}\text { Efeito obser- } \\
\text { vado }\end{array}$ & $\begin{array}{l}\text { Resultado/ Fra- } \\
\text { ção de efeito } \\
(\%)\end{array}$ & $\begin{array}{l}\text { Obje- } \\
\text { tivo }\end{array}$ & Referência \\
\hline $\begin{array}{l}\text { Industrial } \\
\text { (7 indús- } \\
\text { trias) }\end{array}$ & $\begin{array}{l}\text { Photobacterium } \\
\text { phosphoreum, } \\
\text { Euglena gracilis, } \\
\text { Daphnia magna } \\
\text { e Vicia faba }\end{array}$ & $\begin{array}{l}\text { Letalidade, Bi- } \\
\text { oluminescência, } \\
\text { genotoxicidade } \\
\text { e citotoxicidade }\end{array}$ & $\begin{array}{l}5 \text { das } 7 \text { ETEs } \\
\text { apresentaram pi- } \\
\text { ora na toxicidade } \\
\text { pós-tratamento } \\
\text { em algum parâ- } \\
\text { metro }\end{array}$ & $\begin{array}{l}\mathrm{ET} \mathrm{e} \\
\mathrm{BM}\end{array}$ & $\begin{array}{l}\mathrm{Yu} \text { et al. } \\
(2019)\end{array}$ \\
\hline $\begin{array}{l}\text { Industrial } \\
\text { (fárma- } \\
\text { cos) }\end{array}$ & $\begin{array}{l}\text { Biofilmes perifí- } \\
\text { ticos }\end{array}$ & $\begin{array}{l}\text { Diversidade, fo- } \\
\text { tossíntese e ati- } \\
\text { vidade enzimá- } \\
\text { tica }\end{array}$ & $\begin{array}{l}\text { Melhora progres- } \\
\text { siva para cada } \\
\text { etapa de trata- } \\
\text { mento }\end{array}$ & $\begin{array}{l}\mathrm{ET} \mathrm{e} \\
\mathrm{BM}\end{array}$ & $\begin{array}{l}\text { Tardy et al. } \\
\text { (2021) }\end{array}$ \\
\hline $\begin{array}{l}\text { Industrial } \\
\text { (moinho } \\
\text { de } \\
\text { azeite) }\end{array}$ & $\begin{array}{l}\text { Mytilus gallo- } \\
\text { provincialis }\end{array}$ & $\begin{array}{l}\text { Letalidade } \\
\left(\mathrm{LC}_{50}\right), \text { efeitos } \\
\text { citotóxicos, } \\
\text { oxidativos, } \\
\text { neurotóxicos e } \\
\text { genotóxicos }\end{array}$ & $\begin{array}{l}0,255 \% \text { e altera- } \\
\text { ção crônica signifi- } \\
\text { cativa nos tecidos } \\
\text { a partir da fração } \\
0,01 \%\end{array}$ & $\begin{array}{l}\mathrm{ET} \mathrm{e} \\
\mathrm{BM}\end{array}$ & $\begin{array}{l}\text { Danellakis } \\
\text { et al. } \\
(2011)\end{array}$ \\
\hline $\begin{array}{l}\text { Industrial } \\
\text { (moinho } \\
\text { de } \\
\text { azeite) }\end{array}$ & $\begin{array}{l}\text { Fungos do gê- } \\
\text { nero Pleurotus }\end{array}$ & $\begin{array}{l}\text { Crescimento do } \\
\text { micélio }\end{array}$ & $\begin{array}{l}\text { Toxicidade direta- } \\
\text { mente relacionada } \\
\text { a presença de fe- } \\
\text { nóis }\end{array}$ & $\mathrm{BM}$ & $\begin{array}{l}\text { Ntougias et } \\
\text { al. (2013) }\end{array}$ \\
\hline $\begin{array}{l}\text { Industrial } \\
\text { (produ- } \\
\text { tos de } \\
\text { metal) }\end{array}$ & $\begin{array}{l}\text { Pseudokirchne- } \\
\text { riella subca- } \\
\text { pitata, Cerio- } \\
\text { daphnia dúbia e } \\
\text { Danio rerio }\end{array}$ & $\begin{array}{l}\text { Inibição de } \\
\text { crescimento, } \\
\text { reprodução e } \\
\text { ovos fertiliza- } \\
\text { dos (CENO) }\end{array}$ & $\begin{array}{l}\approx 12,5 \%, 1,25 \% \mathrm{e} \\
33,3 \%, \text { respectiva- } \\
\text { mente }\end{array}$ & $\mathrm{BM}$ & $\begin{array}{l}\text { Kusui, } \\
\text { Itatsu e } \\
\text { Jin (2017) }\end{array}$ \\
\hline $\begin{array}{l}\text { Industrial } \\
\text { (produ- } \\
\text { tos } \\
\text { quími- } \\
\text { cos) }\end{array}$ & $\begin{array}{l}\text { Pseudokirchne- } \\
\text { riella subca- } \\
\text { pitata, Cerio- } \\
\text { daphnia dúbia e } \\
\text { Danio rerio }\end{array}$ & $\begin{array}{l}\text { Inibição de } \\
\text { crescimento, } \\
\text { reprodução e } \\
\text { ovos fertiliza- } \\
\text { dos (CENO) }\end{array}$ & $\begin{array}{l}\approx 16 \%, 12 \% \text { e } 3 \%, \\
\text { respectivamente }\end{array}$ & $\mathrm{BM}$ & $\begin{array}{l}\text { Kusui, } \\
\text { Itatsu e } \\
\text { Jin (2017) }\end{array}$ \\
\hline
\end{tabular}

(BM): Biomonitoramento

(ET): Eficiência de Tecnologia 
Tabela 1 - Aplicações de bioensaios em amostras de efluentes

\begin{tabular}{|c|c|c|c|c|c|}
\hline $\begin{array}{l}\text { Tipo } \\
\text { de eflu- } \\
\text { ente }\end{array}$ & $\begin{array}{l}\text { Organismo- } \\
\text { teste }\end{array}$ & $\begin{array}{l}\text { Efeito obser- } \\
\text { vado }\end{array}$ & $\begin{array}{l}\text { Resultado/ Fra- } \\
\text { ção de efeito } \\
(\%)\end{array}$ & $\begin{array}{l}\text { Obje- } \\
\text { tivo }\end{array}$ & Referência \\
\hline $\begin{array}{l}\text { Industrial } \\
\text { (têxtil) }\end{array}$ & $\begin{array}{l}\text { Oreochromis ni- } \\
\text { loticus }\end{array}$ & $\begin{array}{l}\text { Letalidade } \\
\left(\mathrm{LC}_{50}\right)\end{array}$ & $\begin{array}{l}71,5 \% \text { (melhoria } \\
\text { na toxicidade) }\end{array}$ & $\mathrm{ET}$ & $\begin{array}{l}\text { Workagegn } \\
\text { et al. } \\
(2013)\end{array}$ \\
\hline $\begin{array}{l}\text { Industrial } \\
\text { (várias } \\
\text { farma- } \\
\text { cêuticas) }\end{array}$ & $\begin{array}{l}\text { Vibrio qinghai- } \\
\text { ensis }\end{array}$ & $\begin{array}{l}\text { Bioluminescên- } \\
\text { cia }\end{array}$ & $\begin{array}{l}\text { Correlação posi- } \\
\text { tiva entre toxici- } \\
\text { dade e DQO, sóli- } \\
\text { dos suspensos, fós- } \\
\text { foro e nitrogênio }\end{array}$ & $\begin{array}{l}\text { ET e } \\
\text { BM }\end{array}$ & $\begin{array}{l}\text { Ma et al. } \\
(2016)\end{array}$ \\
\hline $\begin{array}{l}\text { Água } \\
\text { marinha }\end{array}$ & Vibrio fischeri & $\begin{array}{l}\text { Bioluminescên- } \\
\text { cia }\end{array}$ & $\begin{array}{l}\text { O pré-tratamento } \\
\text { Fenton tradicional } \\
\text { melhor removeu } \\
\text { toxicidade }\end{array}$ & $\mathrm{ET}$ & $\begin{array}{l}\text { Farinelli et } \\
\text { al. }(2021)\end{array}$ \\
\hline
\end{tabular}

Fim da tabela

Fonte: Elaborada pelo autor

Estudos em universidades brasileiras de diversos estados também já foram conduzidos para avaliação de toxicidade de efluentes, em sua grande parte efluentes industriais (RUBINGER, 2009; MELO, 2012; ALMEIDA et al., 2013). Na cidade de São Carlos o Laboratório de Ecologia e Ambientes Aquáticos (LEAA) da Universidade de São Paulo (USP), estudou a influência dos efluentes de estações de tratamento de esgoto (ISSA, 2019) e de reatores em teste do Laboratório de Processos Biológicos (LPB) da mesma instituição (FELIPE, 2019), parceria que se mantém com a finalidade de atender, além dos parâmetros econômicos e sociais, as demandas ambientais e, portanto, legais.

\subsection{Emergência de fármacos no meio ambiente}

3.3.1 Fármacos e sua dispersão no meio ambiente

A ocorrência de fármacos em corpos d'Água vem sendo pesquisada com mais precisão nos últimos anos, devido ao avanço na detecção de compostos em escalas nanométricas (FRAM; BELITZ, 2011; KOT-WASIK; JAKIMSKA; ŚLIWKA-KASZYŃSKA, 2016; NANTABA et al., 2020; O'FLYNN et al., 2021). Esse avanço permitiu à ciência o conhecimento da repercussão do uso recorrente e descarte inadequado de drogas no meio ambiente, e em especial, seu destino final mais comum: as águas (PEREIRA et al., 2020). 
Presentes em águas superficiais, subterrâneas e na água potável (SATHISHKUMAR et al., 2020) os fármacos se tornam potenciais agentes tóxicos do meio aquático devido a sua concepção ser desenvolvida para alta eficiência em pequenas doses (SANTOS et al., 2010), uma vez que doses pequenas geram efeito no metabolismo humano, espera-se que doses menores ainda dessas concentrações apresentem efeito deletério para organismos aquáticos, o que fundamenta a importância de monitoramento das quantidades desses compostos no meio hídrico.

Os ativos farmacêuticos mais comuns encontrados em águas são os anti-inflamatórios, analgésicos, remédios antiepilépticas, antidepressivos, remédios hipolipemiantes, betabloqueadores, antiulcerosos, anti-histamínicos e antibióticos (RIVERA-UTRILLA et al., 2013). Diversas revisões ao redor do mundo foram feitas para identificar os fármacos mais comuns e em maior concentração em corpos d'água. A Tabela 2 abaixo, elucida alguns resultados obtidos na última década sobre os grupos e fármacos com maior concentração nos corpos hídricos.

Tabela 2 - Grupos e fármacos com maior concentração nos corpos hídricos

\begin{tabular}{|c|c|c|c|c|}
\hline Grupo & Fármaco & Tipo de fonte & $\begin{array}{l}\text { Concentraçã } \\
\text { máxima }\end{array}$ & Referência \\
\hline \multirow[t]{4}{*}{$\begin{array}{l}\text { Analgésico/ } \\
\text { Antitérmico }\end{array}$} & Paracetamol & $\begin{array}{l}\text { Água subterrâ- } \\
\text { nea }\end{array}$ & $1890 \mathrm{ng} / \mathrm{L}$ & $\begin{array}{l}\text { Fram e Belitz } \\
(2011)\end{array}$ \\
\hline & Paracetamol & $\begin{array}{l}\text { Águas superfici- } \\
\text { ais }\end{array}$ & $38 \mathrm{ng} / \mathrm{L}$ & $\begin{array}{l}\text { González-Alonso } \\
\text { et al. (2017) }\end{array}$ \\
\hline & Paracetamol & Esgoto & $28254,4 \mathrm{ng} / \mathrm{L}$ & $\begin{array}{l}\text { Kot-Wasik, Ja- } \\
\text { kimska e Śliwka- } \\
\text { Kaszyńska (2016) }\end{array}$ \\
\hline & Paracetamol & Esgoto & $48744 \mathrm{ng} / \mathrm{L}$ & $\begin{array}{l}\text { González-Alonso } \\
\text { et al. (2017) }\end{array}$ \\
\hline \multirow[t]{4}{*}{ Antibiótico } & Cloranfenicol & $\begin{array}{l}\text { Águas superfici- } \\
\text { ais }\end{array}$ & $39,6 \mathrm{ng} / \mathrm{L}$ & $\begin{array}{l}\text { Gopal et al. } \\
(2021)\end{array}$ \\
\hline & Oxitetraciclina & $\begin{array}{l}\text { Águas superfici- } \\
\text { ais }\end{array}$ & $300 \mathrm{ng} / \mathrm{L}$ & $\begin{array}{l}\text { Nantaba et al. } \\
(2020)\end{array}$ \\
\hline & Sulfadiazina & Esgoto & $535 \mathrm{ng} / \mathrm{L}$ & $\begin{array}{l}\text { González-Alonso } \\
\text { et al. (2017) }\end{array}$ \\
\hline & Sulfametoxazol & $\begin{array}{l}\text { Águas superfici- } \\
\text { ais }\end{array}$ & $5600 \mathrm{ng} / \mathrm{L}$ & $\begin{array}{l}\text { Nantaba et al. } \\
(2020)\end{array}$ \\
\hline
\end{tabular}


Tabela 2-Grupos e fármacos com maior concentração nos corpos hídricos

\begin{tabular}{|c|c|c|c|c|}
\hline \multirow[t]{3}{*}{ Grupo } & \multirow{2}{*}{$\begin{array}{l}\text { Fármaco } \\
\text { Sulfametoxazol }\end{array}$} & \multirow{2}{*}{$\begin{array}{l}\text { Tipo de fonte } \\
\text { Águas superfici- } \\
\text { ais }\end{array}$} & \multicolumn{2}{|c|}{$\begin{array}{l}\text { Concentração Referência } \\
\text { máxima }\end{array}$} \\
\hline & & & $76,7 \mathrm{ng} / \mathrm{L}$ & $\begin{array}{l}\text { Gopal et al. } \\
(2021)\end{array}$ \\
\hline & Claritromicina & $\begin{array}{l}\text { Águas superfici- } \\
\text { ais }\end{array}$ & $20 \mathrm{ng} / \mathrm{L}$ & $\begin{array}{l}\text { González-Alonso } \\
\text { et al. (2017) }\end{array}$ \\
\hline \multirow[t]{3}{*}{ Antiepilético } & Carbamazepina & $\begin{array}{l}\text { Água subterrâ- } \\
\text { nea }\end{array}$ & $40 \mathrm{ng} / \mathrm{L}$ & $\begin{array}{l}\text { Fram e Belitz } \\
(2011)\end{array}$ \\
\hline & Carbamazepina & $\begin{array}{l}\text { Águas superfici- } \\
\text { ais }\end{array}$ & $72 \mathrm{ng} / \mathrm{L}$ & $\begin{array}{l}\text { Nantaba et al. } \\
(2020)\end{array}$ \\
\hline & Carbamazepina & Esgoto & $3217,1 \mathrm{ng} / \mathrm{L}$ & $\begin{array}{l}\text { Kot-Wasik, Ja- } \\
\text { kimska e Śliwka- } \\
\text { Kaszyńska (2016) }\end{array}$ \\
\hline \multirow[t]{10}{*}{$\begin{array}{l}\text { Anti- } \\
\text { inflamatório }\end{array}$} & Ácido salicílico & Esgoto & $27014,2 \mathrm{ng} / \mathrm{L}$ & $\begin{array}{l}\text { Kot-Wasik, Ja- } \\
\text { kimska e Śliwka- } \\
\text { Kaszyńska (2016) }\end{array}$ \\
\hline & Diclofenaco & $\begin{array}{l}\text { Águas superfici- } \\
\text { ais }\end{array}$ & $7761 \mathrm{ng} / \mathrm{L}$ & $\begin{array}{l}\text { González-Alonso } \\
\text { et al. }(2017)\end{array}$ \\
\hline & Diclofenaco & $\begin{array}{l}\text { Águas superfici- } \\
\text { ais }\end{array}$ & $160 \mathrm{ng} / \mathrm{L}$ & $\begin{array}{l}\text { Nantaba et al. } \\
(2020)\end{array}$ \\
\hline & Diclofenaco & $\begin{array}{l}\text { Águas superfici- } \\
\text { ais }\end{array}$ & $230 \mathrm{ng} / \mathrm{L}$ & $\begin{array}{l}\text { Gopal et al. } \\
(2021)\end{array}$ \\
\hline & Diclofenaco & Esgoto & 4001,4 ng/L & $\begin{array}{l}\text { Kot-Wasik, Ja- } \\
\text { kimska e Śliwka- } \\
\text { Kaszyńska (2016) }\end{array}$ \\
\hline & Diclofenaco & Esgoto & $15087 \mathrm{ng} / \mathrm{L}$ & $\begin{array}{l}\text { González-Alonso } \\
\text { et al. (2017) }\end{array}$ \\
\hline & Ibuprofeno & $\begin{array}{l}\text { Águas superfici- } \\
\text { ais }\end{array}$ & $974 \mathrm{ng} / \mathrm{L}$ & $\begin{array}{l}\text { González-Alonso } \\
\text { et al. (2017) }\end{array}$ \\
\hline & Ibuprofeno & $\begin{array}{l}\text { Águas superfici- } \\
\text { ais }\end{array}$ & $780 \mathrm{ng} / \mathrm{L}$ & $\begin{array}{l}\text { Nantaba et al. } \\
(2020)\end{array}$ \\
\hline & Ibuprofeno & $\begin{array}{l}\text { Águas superfici- } \\
\text { ais }\end{array}$ & $1834 \mathrm{ng} / \mathrm{L}$ & $\begin{array}{l}\text { Gopal et al. } \\
(2021)\end{array}$ \\
\hline & Ibuprofeno & Esgoto & $10864,0 \mathrm{ng} / \mathrm{L}$ & $\begin{array}{l}\text { Kot-Wasik, Ja- } \\
\text { kimska e Śliwka- } \\
\text { Kaszyńska (2016) }\end{array}$ \\
\hline
\end{tabular}


Tabela 2 - Grupos e fármacos com maior concentração nos corpos hídricos

\begin{tabular}{|c|c|c|c|c|}
\hline \multirow[t]{2}{*}{ Grupo } & \multirow{2}{*}{$\begin{array}{l}\text { Fármaco } \\
\text { Ibuprofeno }\end{array}$} & \multirow{2}{*}{$\begin{array}{l}\text { Tipo de fonte } \\
\text { Esgoto }\end{array}$} & \multicolumn{2}{|c|}{$\begin{array}{l}\text { Concentração Referência } \\
\text { máxima }\end{array}$} \\
\hline & & & $10053 \mathrm{ng} / \mathrm{L}$ & $\begin{array}{l}\text { González-Alonso } \\
\text { et al. }(2017)\end{array}$ \\
\hline $\begin{array}{l}\text { Beta- } \\
\text { bloqueador }\end{array}$ & Atenolol & $\begin{array}{l}\text { Águas superfici- } \\
\text { ais }\end{array}$ & $380 \mathrm{ng} / \mathrm{L}$ & $\begin{array}{l}\text { Nantaba et al. } \\
(2020)\end{array}$ \\
\hline \multirow[t]{4}{*}{ Estimulante } & Cafeína & $\begin{array}{l}\text { Água subterrâ- } \\
\text { nea }\end{array}$ & $290 \mathrm{ng} / \mathrm{L}$ & $\begin{array}{l}\text { Fram e Belitz } \\
(2011)\end{array}$ \\
\hline & Cafeína & $\begin{array}{l}\text { Águas superfici- } \\
\text { ais }\end{array}$ & $322,89 \mathrm{ng} / \mathrm{L}$ & $\begin{array}{l}\text { González-Alonso } \\
\text { et al. (2017) }\end{array}$ \\
\hline & Cafeína & Esgoto & $22193,8 \mathrm{ng} / \mathrm{L}$ & $\begin{array}{l}\text { Kot-Wasik, Ja- } \\
\text { kimska e Śliwka- } \\
\text { Kaszyńska (2016) }\end{array}$ \\
\hline & Cafeína & Esgoto & $71331 \mathrm{ng} / \mathrm{L}$ & $\begin{array}{l}\text { González-Alonso } \\
\text { et al. (2017) }\end{array}$ \\
\hline
\end{tabular}

Fim da tabela

Dentre os fármacos presentes nas águas superficiais, subterrâneas e em efluentes a Tabela 2 realça a presença de um grupo de fármacos que tem sua presença identificada em maiores concentrações em águas superficiais, os anti-inflamatórios não esteroidais (AINE's). Dentro desse grupo o diclofenaco, um anti-inflamatório não esteroidais, foi enquadrado na watch-list da União Europeia como contaminante de preocupação emergente (TANG et al., 2020), sua repercussão e efeitos no meio ambiente será, por isso, melhor detalhada nos tópicos subsequentes.

\subsubsection{O anti-inflamatório diclofenaco}

O diclofenaco (DCF) é um anti-inflamatório não esteroidal de comprovada eficiência no tratamento de inflamações, febres e dores musculares (GAN, 2010). O DCF foi desenvolvido para inibir a enzima cicloxigenase um e dois (COX-1 e -2), que é responsável pelo processo de síntese de prostaglandina, mediadora de processos inflamatórios (GAN, 2010), a inibição da COX-1 tem como uma das consequências danos ao trato gastrointestinal (NATIONAL CENTER FOR BIOTECHNOLOGY INFORMATION, 2021), outros efeitos colaterais do uso de Diclofenaco, como danos renais e cardiovasculares, já foram reportados (ALTMAN et al., 2015).

O Diclofenaco é um ácido monocarboxílico que consiste em ácido fenilacético tendo um grupo (2,6-diclorofenil) amino na posição 2 (National Center for Biotechnology 
Information, 2021), possui estrutura química composta de moléculas de carbono, hidrogênio, cloro, nitrogênio e oxigênio com fórmula C14H11Cl2NO2, massa molecular de 296,2 g/mol e número CAS = 15307-86-5 (NANTABA et al., 2020). O coeficiente de partição do DCF é de 13,4, o que indica parcial solubilidade em meio aquoso ou hidrofóbico, quando associado a outras moléculas como o Sódio ou o Potássio assume a forma de sal e influencia no tempo de absorção do fármaco pelo organismo (ALTMAN et al., 2015). A representação gráfica da molécula do Diclofenaco é apresentada na Figura 5.

Figura 5 - Representação molecular do Diclofenaco a) Estrutura química em 2D b) Estrutura em 3D

a)

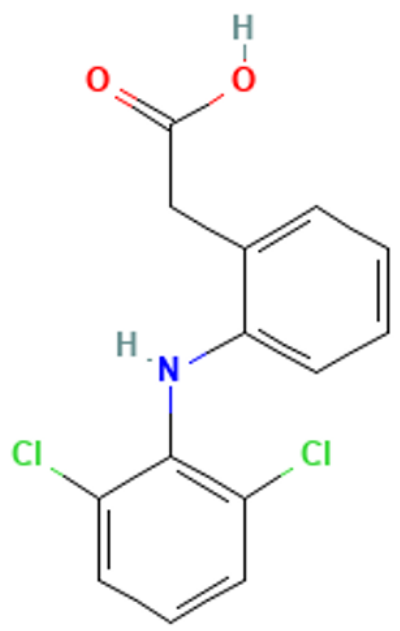

b)

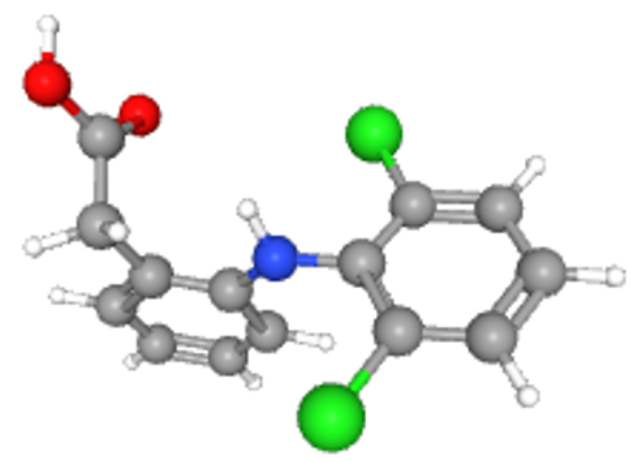

Fonte: National Center for Biotechnology Information (2021)

A presença do Diclofenaco em corpos hídricos vem sendo monitorada nas últimas décadas nos corpos receptores ao redor do mundo, algumas essas pesquisas e revisões foram sintetizadas na Tabela 3, em ordem crescente de concentração detectada.

Tabela 3 - Concentração máxima do diclofenaco encontrada em corpos hídricos

\begin{tabular}{|c|c|c|c|}
\hline $\begin{array}{l}\text { Tipo de } \\
\text { fonte }\end{array}$ & País & $\begin{array}{l}\text { Concentração } \\
\text { máxima }\end{array}$ & Referência \\
\hline \multirow{3}{*}{$\begin{array}{l}\text { Água } \\
\text { rânea }\end{array}$} & Camarões & $518 \mathrm{ng} / \mathrm{L}$ & Branchet et al. (2019) \\
\hline & China & $522,8 \mathrm{ng} / \mathrm{L}$ & Lu et al. (2016) \\
\hline & Alemanha & $590 \mathrm{ng} / \mathrm{L}$ & Sacher et al. (2001) \\
\hline $\begin{array}{l}\text { Água superfi- } \\
\text { cial }\end{array}$ & Uganda & $160 \mathrm{ng} / \mathrm{L}$ & Nantaba et al. (2020) \\
\hline
\end{tabular}


Tabela 3 - Concentração máxima do diclofenaco encontrada em corpos hídricos

\begin{tabular}{|c|c|c|c|}
\hline $\begin{array}{l}\text { Tipo de } \\
\text { fonte }\end{array}$ & País & $\begin{array}{l}\text { Concentração } \\
\text { máxima }\end{array}$ & Referência \\
\hline & Índia & $230 \mathrm{ng} / \mathrm{L}$ & Gopal et al. (2021) \\
\hline & Brasil & $364 \mathrm{ng} / \mathrm{L}$ & Sousa et al. (2018) \\
\hline & Camarões & $419 \mathrm{ng} / \mathrm{L}$ & Branchet et al. (2019) \\
\hline & China & $645 \mathrm{ng} / \mathrm{L}$ & Peng et al. (2017) \\
\hline & Brasil & $785 \mathrm{ng} / \mathrm{L}$ & Thomas et al. (2014) \\
\hline & Alemanha & $1200 \mathrm{ng} / \mathrm{L}$ & Ternes (1998) \\
\hline & Alemanha & $2100 \mathrm{ng} / \mathrm{L}$ & Schmidt et al. (2018) \\
\hline & Paquistão & $4400 \mathrm{ng} / \mathrm{L}$ & Scheurell et al. (2009) \\
\hline & $\begin{array}{l}\text { Península da An- } \\
\text { tártida }\end{array}$ & $7761 \mathrm{ng} / \mathrm{L}$ & $\begin{array}{l}\text { González-Alonso et al. } \\
(2017)\end{array}$ \\
\hline & Nigéria & $57160 \mathrm{ng} / \mathrm{L}$ & Olaitan et al. (2014) \\
\hline & Paquistão & $116000 \mathrm{ng} / \mathrm{L}$ & Hanif et al. (2020) \\
\hline $\begin{array}{l}\text { Drenagem ur- } \\
\text { bana }\end{array}$ & Paquistão & $8500 \mathrm{ng} / \mathrm{L}$ & Scheurell et al. (2009) \\
\hline \multirow[t]{10}{*}{ Esgoto } & França & $486,4 \mathrm{ng} / \mathrm{L}$ & Togola e Budzinski (2008) \\
\hline & Eslovênia/Croácia & $812 \mathrm{ng} / \mathrm{L}$ & Česen et al. (2019) \\
\hline & Portugal & $1137,5 \mathrm{ng} / \mathrm{L}$ & Pereira et al. (2016)6 \\
\hline & Alemanha & $2100 \mathrm{ng} / \mathrm{L}$ & Ternes (1998) \\
\hline & Polônia & $4001,4 \mathrm{ng} / \mathrm{L}$ & $\begin{array}{l}\text { Kot-Wasik, Jakimska e } \\
\text { Śliwka-Kaszyńska (2016) }\end{array}$ \\
\hline & Alemanha & $5100 \mathrm{ng} / \mathrm{L}$ & Stülten et al. (2008) \\
\hline & Alemanha & $6300 \mathrm{ng} / \mathrm{L}$ & Schmidt et al. (2018) \\
\hline & $\begin{array}{l}\text { Península da An- } \\
\text { tártida }\end{array}$ & $15087 \mathrm{ng} / \mathrm{L}$ & $\begin{array}{l}\text { González-Alonso et } \\
(2017)\end{array}$ \\
\hline & Índia & $25680 \mathrm{ng} / \mathrm{L}$ & Singh et al. (2014) \\
\hline & Paquistão & $836000 \mathrm{ng} / \mathrm{L}$ & Ashfaq et al. (2017) \\
\hline
\end{tabular}

Fonte: Adaptado e atualizado de Sathishkumar et al. (2020)

Como pode ser observado na Tabela 3, o DCF chega a alcançar concentrações de 116 $\mu \mathrm{g} / \mathrm{L}$ em águas superficiais e $836 \mu \mathrm{g} / \mathrm{L}$ em efluentes. Conhecido os valores quantitativos da ocorrência do DCF nos corpos hídricos, é importante conhecer os efeitos dessas proporções para os organismos aquáticos expostos a essa contaminação, e só assim determinar limites aceitáveis da presença dele no meio ambiente. 


\subsubsection{Toxicidade do Diclofenaco}

Muitos estudos confirmam o efeito tóxico do Diclofenaco em organismos aquáticos. Dentre os efeitos observados, destaca-se o crescimento na atividade cicloxigenase (COX), estresse oxidativo e queda no nível de lipídios no mexilhão Perna perna (FONTES et $a l ., 2018$ ), a detecção de prostaglandina (indicando a inibição das atividades de COX) no mexilhão Mytilus galloprovincialis (COURANT et al., 2018) e queda no nível de peroxidação lipídica em embriões do Danio rerio, sugerindo indução do biomarcador de proteotoxicidade Hsp70 (FEITO; VALCÁRCEL; CATALÁ, 2012). Todos esses efeitos indicam que o mesmo modo de ação do fármaco em humanos é observado em organismos de estrutura morfológica divergente.

Os limiares da concentração de DCF que leva à letalidade de $50 \%$ dos organismos expostos a ele $\left(\mathrm{CL}_{50}\right.$ ou $\left.\mathrm{CE}_{50}\right)$ foram pesquisados nos últimos anos, e alguns dados foram compilados na Tabela 4 em ordem decrescente de toxicidade.

Tabela 4 - Toxicidade aguda do diclofenaco aos organismos aquáticos (CL50 e CE50)

\begin{tabular}{|c|c|c|c|c|}
\hline $\begin{array}{l}\text { Organismo- } \\
\text { teste }\end{array}$ & Grupo & Observações & $\begin{array}{l}\mathrm{CL}_{50} \\
\mathrm{CE}_{50}\end{array}$ & Referência \\
\hline Danio rerio & Peixe & Embriões & $5,49 \mathrm{mg} / \mathrm{L}$ & $\begin{array}{l}\text { Praskova et al. } \\
(2011)\end{array}$ \\
\hline Lemna minor & Macrófita & 7 dias & $7,5 \mathrm{mg} / \mathrm{L}$ & Cleuvers (2003) \\
\hline Vibrio fisheri & Bactéria & $30 \mathrm{~min}$ & $11,45 \mathrm{mg} / \mathrm{L}$ & $\begin{array}{l}\text { Ferrari et al. } \\
(2003)\end{array}$ \\
\hline $\begin{array}{l}\text { Ceriodaphnia sil- } \\
\text { vestrii }\end{array}$ & Crustáceo & $48 \mathrm{~h}$ & $14,59 \mathrm{mg} / \mathrm{L}$ & $\begin{array}{l}\text { Caldas et al. } \\
(2021)\end{array}$ \\
\hline Daphnia magna & Crustáceo & $48 \mathrm{~h}$ & $18,1 \mathrm{mg} / \mathrm{L}$ & Du et al. (2016) \\
\hline $\begin{array}{l}\text { Ceriodaphnia dú- } \\
\text { bia }\end{array}$ & Crustáceo & $48 \mathrm{~h}$ & $22,7 \mathrm{mg} / \mathrm{L}$ & $\begin{array}{lll}\text { Ferrari et al. } \\
(2003) 3\end{array}$ \\
\hline $\begin{array}{l}\text { Chironomus } \\
\text { tepperi }\end{array}$ & Inseto & $\begin{array}{l}7 \text { dias, } 1^{\mathrm{o}} \text { ins- } \\
\text { tar }\end{array}$ & $23 \mathrm{mg} / \mathrm{L}$ & $\begin{array}{l}\text { Gonzago e } \mathrm{Ku}- \\
\operatorname{mar}(2013)\end{array}$ \\
\hline $\begin{array}{l}\text { Ceriodaphnia sil- } \\
\text { vestrii }\end{array}$ & Crustáceo & - & $37,9 \mathrm{mg} / \mathrm{L}$ & $\begin{array}{l}\text { Oliveira et al. } \\
(2018)\end{array}$ \\
\hline Daphnia magna & Crustáceo & $48 \mathrm{~h}$ & $39,9 \mathrm{mg} / \mathrm{L}$ & $\begin{array}{ll}\text { Haap, } & \text { Triebs- } \\
\text { korn e } & \text { Köhler } \\
(2008) & \end{array}$ \\
\hline Daphnia similis & Crustáceo & $48 \mathrm{~h}$ & $46 \mathrm{mg} / \mathrm{L}$ & $\begin{array}{l}\text { CASTRO et al. } \\
(2014)\end{array}$ \\
\hline
\end{tabular}


Tabela 4 - Toxicidade aguda do diclofenaco aos organismos aquáticos

\begin{tabular}{|c|c|c|c|c|}
\hline $\begin{array}{l}\text { Organismo- } \\
\text { teste }\end{array}$ & Grupo & Observações & $\begin{array}{ll}\mathrm{CL}_{50} & \text { ou } \\
\mathrm{CE}_{50} & \\
\end{array}$ & Referência \\
\hline Daphnia magna & Crustáceo & $48 \mathrm{~h}$ & $68 \mathrm{mg} / \mathrm{L}$ & Cleuvers (2004) \\
\hline $\begin{array}{l}\text { Desmodesmus } \\
\text { subspicatus }\end{array}$ & Alga & - & $72 \mathrm{mg} / \mathrm{L}$ & Cleuvers (2004) \\
\hline Daphnia magna & Crustáceo & $48 \mathrm{~h}$ & $91 \mathrm{mg} / \mathrm{L}$ & $\begin{array}{l}\text { Woermann e Su- } \\
\text { res }(2020)\end{array}$ \\
\hline Daphnia magna & Crustáceo & $48 \mathrm{~h}$ & $96,6 \mathrm{mg} / \mathrm{L}$ & $\begin{array}{l}\text { Gómez-Oliván et } \\
\text { al. (2014) }\end{array}$ \\
\hline $\begin{array}{l}\text { Chironomus aprili- } \\
\text { nus }\end{array}$ & Inseto & $48 \mathrm{~h}, 1^{\mathrm{o}}$ instar & $105,2 \mathrm{mg} / \mathrm{L}$ & $\begin{array}{l}\text { Matejczyk et al. } \\
(2020)\end{array}$ \\
\hline $\begin{array}{l}\text { Chironomus ripa- } \\
\text { rius }\end{array}$ & Inseto & - & $156 \mathrm{mg} / \mathrm{L}$ & Xie et al. (2020) \\
\hline Danio rerio & Peixe & 96h, juvenil & $166 \mathrm{mg} / \mathrm{L}$ & $\begin{array}{l}\text { Praskova et al. } \\
(2011)\end{array}$ \\
\hline
\end{tabular}

Conforme observado na Tabela 4 acima, o DCF apresenta efeito de toxicidade aguda a $50 \%$ dos organismos aquáticos exposto a partir de miligramas por litros, quando o observado nos corpos receptores, de acordo com o levantamento apresentado na Tabela 3, são concentrações de microgramas por litro. Embora as concentrações de letalidade não sejam comumente detectadas nos corpos hídricos, a mortalidade é uma resposta extrema e não é utilizada como limiar de concentração aceitável nos corpos receptores pelas agências ambientais europeias (European Community), que estabeleceram a média permitida anualmente de DCF nos corpos hídricos seria de $100 \mathrm{ng} / \mathrm{L}$, com base em ensaios crônicos (JOHNSON et al., 2013).

A toxicidade do DCF é dependente do tempo de exposição e da concentração da substância no meio teste (DU et al., 2016). Os ensaios de toxicidade aguda são em grande parte desenvolvidos em curtos períodos de exposição e em concentrações elevadas do fármaco, como é observado na Tabela 4. No entanto, o observado com maior frequência no meio ambiente são concentrações menores e constantemente disponíveis para a biota aquática. Dessa forma, os ensaios de toxicidade crônica também são relevantes na compreensão da toxidade do DCF para a comunidade aquática, no que se refere aos efeitos subletais e a longo prazo. Na Tabela 5 abaixo é apresentado um apanhado de algumas pesquisas desenvolvidas para identificar os efeitos crônicos do DCF. 
Tabela 5 - Toxicidade crônica do diclofenaco aos organismos aquáticos

\begin{tabular}{|c|c|c|c|c|}
\hline Grupo & $\begin{array}{l}\text { Organismo- } \\
\text { teste }\end{array}$ & Efeito observado & $\begin{array}{l}\text { Resultado ob- } \\
\text { tido }\end{array}$ & Referência \\
\hline Crustáceo & $\begin{array}{l}\text { Daphnia } \\
\text { magna }\end{array}$ & $\begin{array}{l}\text { Indução de Hsp70 } \\
\text { (CEO) }\end{array}$ & $40 \mathrm{mg} / \mathrm{L}$ & $\begin{array}{ll}\text { Haap, } & \text { Triebs- } \\
\text { korn e } & \text { Köhler } \\
(2008) & \end{array}$ \\
\hline Crustáceo & $\begin{array}{l}\text { Daphnia } \\
\text { magna }\end{array}$ & $\begin{array}{l}\text { Letalidade após } 21 \\
\text { dias }\left(\mathrm{CE}_{50}\right)\end{array}$ & $\begin{array}{l}2.00 \pm 0.30 \\
\mathrm{mg} / \mathrm{L}\end{array}$ & Du et al. (2016) \\
\hline Crustáceo & $\begin{array}{l}\text { Daphnia } \\
\text { magna }\end{array}$ & $\begin{array}{l}\text { Indução de estresse } \\
\text { oxidativo em } 48 \mathrm{~h} \\
(\mathrm{CEO})\end{array}$ & $9,7 \mathrm{mg} / \mathrm{L}$ & $\begin{array}{l}\text { Gómez-Oliván et } \\
\text { al. (2014) }\end{array}$ \\
\hline Crustáceo & $\begin{array}{l}\text { Daphnia } \\
\text { magna }\end{array}$ & $\begin{array}{l}\text { Letalidade após } 21 \\
\text { dias }\left(\mathrm{CE}_{50}\right)\end{array}$ & $17,0 \mathrm{mg} / \mathrm{L}$ & $\begin{array}{l}\text { Woermann e Su- } \\
\text { res }(2020)\end{array}$ \\
\hline Crustáceo & $\begin{array}{l}\text { Daphnia } \\
\text { magna }\end{array}$ & $\begin{array}{l}\text { Indução de genes re- } \\
\text { lacionados à desin- } \\
\text { toxicação e atraso } \\
\text { na reprodução }\end{array}$ & $\begin{array}{l}\text { A partir de } 50 \\
\mu \mathrm{g} / \mathrm{L}\end{array}$ & Liu et al. (2017b) \\
\hline Crustáceo & $\begin{array}{l}\text { Hyalella } \\
\text { azteca }\end{array}$ & $\begin{array}{l}\text { Inibição de síntese } \\
\text { de prostaglandina e } \\
\text { via de transporte da } \\
\text { carnitina }\end{array}$ & $\begin{array}{l}\text { A partir de } 10 \\
\mu \mathrm{g} / \mathrm{L}\end{array}$ & $\mathrm{Fu}$ et al. (2021) \\
\hline Crustáceo & $\begin{array}{l}\text { Hyalella } \\
\text { azteca }\end{array}$ & $\begin{array}{l}\text { Estresse oxidativo } \\
\text { em } 12 \mathrm{~h} \text { de exposi- } \\
\text { ção }\end{array}$ & $46,7 \mu \mathrm{g} / \mathrm{kg}$ & $\begin{array}{l}\text { Oviedo-Gómez } \\
\text { et al. (2010) }\end{array}$ \\
\hline Inseto & $\begin{array}{l}\text { Chironomus } \\
\text { riparius }\end{array}$ & $\begin{array}{l}\text { Diminuição na taxa } \\
\text { de emergência }\end{array}$ & $\begin{array}{l}\text { A partir da } \\
\text { concentração } 34 \\
\mu \mathrm{g} / \mathrm{g}\end{array}$ & $\begin{array}{l}\text { Nieto et al. } \\
(2017)\end{array}$ \\
\hline Inseto & $\begin{array}{l}\text { Hydropsyche } \\
\text { spp. }\end{array}$ & $\begin{array}{l}\text { Bioacumulação } \\
\text { em indivíduos } \\
\text { coletados nos rios }\end{array}$ & $12,4 \mathrm{ng} / \mathrm{g}$ & $\begin{array}{l}\text { Buitrago et al. } \\
(2015)\end{array}$ \\
\hline Macrófita & $\begin{array}{l}\text { Azolla filicu- } \\
\text { loides }\end{array}$ & $\begin{array}{l}\text { Impacto na eficiên- } \\
\text { cia fotossintética }\end{array}$ & $\begin{array}{l}\text { A partir de } 100 \\
\mu \mathrm{g} / \mathrm{L}\end{array}$ & $\begin{array}{l}\text { Vannini et al. } \\
(2018)\end{array}$ \\
\hline Macrófita & $\begin{array}{l}\text { Lemna min- } \\
\text { nor }\end{array}$ & $\begin{array}{l}\text { Impacto na produ- } \\
\text { ção de clorofila a e } \\
\text { b }\end{array}$ & $\begin{array}{l}\text { A partir de } 20 \\
\mu \mathrm{g} / \mathrm{L}\end{array}$ & $\begin{array}{l}\text { Alkimin et al. } \\
(2019)\end{array}$ \\
\hline
\end{tabular}


Tabela 5 - Toxicidade crônica do diclofenaco aos organismos aquáticos

\begin{tabular}{|c|c|c|c|c|}
\hline Grupo & $\begin{array}{l}\text { Organismo- } \\
\text { teste }\end{array}$ & Efeito observado & $\begin{array}{l}\text { Resultado ob- } \\
\text { tido }\end{array}$ & Referência \\
\hline Mexilhão & $\begin{array}{l}\text { Dreissena } \\
\text { polymorpha }\end{array}$ & $\begin{array}{l}\text { Lesões genéticas pri- } \\
\text { márias e danos fixos } \\
\text { ao DNA }\end{array}$ & $\begin{array}{l}\text { A partir da } \\
\text { concentração } \\
60 \mu \mathrm{g} / \mathrm{L}\end{array}$ & $\begin{array}{l}\text { Parolini, Binelli } \\
\text { e Provini (2011) }\end{array}$ \\
\hline Mexilhão & $\begin{array}{l}\text { Mytilus gallo- } \\
\text { provincialis }\end{array}$ & $\begin{array}{l}\text { Alteração estrogê- } \\
\text { nica, impactos nos } \\
\text { tecidos, crescimento } \\
\text { e metabolismo }\end{array}$ & $\begin{array}{l}15 \text { dias de expo- } \\
\text { sição a } 250 \mathrm{ng} / \mathrm{L}\end{array}$ & $\begin{array}{l}\text { Lonappan et al. } \\
(2016)\end{array}$ \\
\hline Mexilhão & Perna perna & $\begin{array}{l}\text { Estresse oxidativo, } \\
\text { danos ao DNA } \\
\text { no tecido das } \\
\text { brânquias }\end{array}$ & $200 \mathrm{ng} / \mathrm{L}$ & $\begin{array}{l}\text { Fontes et al. } \\
(2018)\end{array}$ \\
\hline Mexilhão & $\begin{array}{l}\text { Ruditapes phi- } \\
\text { lippinarum }\end{array}$ & $\begin{array}{l}\text { Impactos no desen- } \\
\text { volvimento larval }\end{array}$ & $0,5 \mu \mathrm{g} / \mathrm{L}$ & $\begin{array}{l}\text { Munari et al. } \\
(2016)\end{array}$ \\
\hline $\begin{array}{l}\text { Microrganis- } \\
\text { mos }\end{array}$ & Biofilme & $\begin{array}{l}\text { Impactos na estru- } \\
\text { tura da comunidade } \\
\text { e funções }\end{array}$ & 10 e $100 \mu \mathrm{g} / \mathrm{L}$ & $\begin{array}{l}\text { Lawrence et al. } \\
(2007)\end{array}$ \\
\hline Molusco & $\begin{array}{l}\text { Lymnaea stag- } \\
\text { nalis }\end{array}$ & $\begin{array}{l}\text { Indução de resposta } \\
\text { imune }\end{array}$ & $\begin{array}{l}\text { A partir de } \\
\text { concentrações de } \\
100 \mu \mathrm{g} / \mathrm{L}\end{array}$ & $\begin{array}{l}\text { Boisseaux et al. } \\
(2017)\end{array}$ \\
\hline Peixe & $\begin{array}{l}\text { Cyprinus car- } \\
\text { pio }\end{array}$ & $\begin{array}{l}\text { Estresse oxidativo } \\
\text { em brânquias e fí- } \\
\text { gado }\end{array}$ & $100 \mu \mathrm{g} / \mathrm{L}$ & $\begin{array}{l}\text { Nava-Álvarez et } \\
\text { al. (2014) }\end{array}$ \\
\hline Peixe & $\begin{array}{l}\text { Oncorhynchus } \\
\text { mykiss }\end{array}$ & $\begin{array}{l}\text { Cociente de risco } \\
(\mathrm{RQ})\end{array}$ & $\begin{array}{l}\text { Alto risco ecoló- } \\
\text { gico na concen- } \\
\text { tração detectada } \\
(116 \mu \mathrm{g} / \mathrm{L})\end{array}$ & $\begin{array}{l}\text { Hanif et al. } \\
(2020)\end{array}$ \\
\hline Peixe & $\begin{array}{l}\text { Salmo trutta } f \text {. } \\
\text { fario }\end{array}$ & $\begin{array}{l}\text { Dano nos rins, teci- } \\
\text { dos, brânquias e fí- } \\
\text { gado }\end{array}$ & $\begin{array}{l}50 \mu \mathrm{g} / \mathrm{L} \text { em } 21 \\
\text { dias }\end{array}$ & $\begin{array}{l}\text { Hoeger et al. } \\
(2005)\end{array}$ \\
\hline
\end{tabular}

Fim da tabela

Os dados da Tabela 5 apontam para efeitos adversos em organismos aquáticos a partir de concentrações de $200 \mathrm{ng} / \mathrm{L}$. Essa concentração é facilmente detectada em corpos receptores ao redor do mundo e muito próximo da concentração detectada nas águas 
superficiais brasileiras (Tabela 3). Esses dados ressaltam a importância da investigação dos efeitos do DCF em organismos representativos da fauna tropical, em específico, organismos normalmente encontrados no Brasil, para a definição de limites nacionais permitido de substâncias. 



\section{MATERIAIS E MÉTODOS}

\subsection{Cultivo e manutenção das espécies}

O cultivo dos organismos Allonais inaequalis, Pristina longiseta, Chironomus sancticaroli e Ceriodaphnia silvestrii é mantido no Laboratório de Ecologia de Ambientes Aquáticos (LEAA), Escola de Engenharia de São Carlos, Universidade de São Paulo sob as condições de cultivo indicadas na Tabela 6 .

Tabela 6 - Condições de cultivo mantidas no Laboratório de Ecologia de Ambientes Aquáticos

\begin{tabular}{|c|c|c|c|c|}
\hline Condição & $\begin{array}{l}\text { Allonais ina- } \\
\text { equalis }\end{array}$ & $\begin{array}{l}\text { Pristina lon- } \\
\text { giseta }\end{array}$ & $\begin{array}{l}\text { Ceriodaphnia } \\
\text { silvestrii }\end{array}$ & $\begin{array}{l}\text { Chironomus } \\
\text { sancticaroli }\end{array}$ \\
\hline Temperatura & 23 a $27{ }^{\circ} \mathrm{C}$ & 23 a $27^{\circ} \mathrm{C}$ & 23 a $27^{\circ} \mathrm{C}$ & 23 a $27^{\circ} \mathrm{C}$ \\
\hline Fotoperíodo & $\begin{array}{l}12 \mathrm{~h} \mathrm{luz} / 12 \mathrm{~h} \\
\text { escuro }\end{array}$ & $\begin{array}{l}12 \mathrm{~h} \mathrm{luz} / 12 \mathrm{~h} \\
\text { escuro }\end{array}$ & $\begin{array}{l}12 \mathrm{~h} \text { luz/12 h } \\
\text { escuro }\end{array}$ & $\begin{array}{l}12 \mathrm{~h} \mathrm{luz} / 12 \mathrm{~h} \\
\text { escuro }\end{array}$ \\
\hline $\begin{array}{l}\text { Componentes } \\
\text { do meio }\end{array}$ & $\begin{array}{l}\text { Areia muflada } \\
\text { e água sem } \\
\text { cloro }\end{array}$ & $\begin{array}{l}\text { Areia muflada } \\
\text { e água sem } \\
\text { cloro }\end{array}$ & $\begin{array}{l}\text { Água reconsti- } \\
\text { tuída }\end{array}$ & $\begin{array}{l}\text { Areia muflada } \\
\text { e água sem } \\
\text { cloro }\end{array}$ \\
\hline Alimentação & Tetramin ${ }^{\circledR}$ & Tetramin ${ }^{\circledR}$ & $\begin{array}{l}\text { Aditivo alimen- } \\
\text { tar e suspensão } \\
\text { algácea }\end{array}$ & Tetramin ${ }^{\circledR}$ \\
\hline Metodologia & $\begin{array}{l}\text { Corbi, Gorni e } \\
\text { Correa (2015) }\end{array}$ & $\begin{array}{l}\text { Castro et al. } \\
(2020)\end{array}$ & ABNT 2017 & $\begin{array}{l}\text { OECD } 235 \\
2011, \text { Fonseca } \\
(1997)\end{array}$ \\
\hline
\end{tabular}

Fonte: Próprio do autor (2021)

O cultivo da espécie Chironomus sancticaroli é realizado conforme adaptação dos procedimentos recomendados por Trivinho-Strixino e Strixino (1995) e Fonseca (1997). Assim, as espécies são cultivadas sob aeração constante em bandejas de plástico $(38 \mathrm{~cm}$ de comprimento por $33 \mathrm{~cm}$ de largura), contendo água sem cloro e 0,6 cm de sedimento previamente tratado (areia fina, 4 horas na mufla a 550 graus). As bandejas são revestidas por suporte metálico com redes de plástico, para evitar a perda dos organismos em fase adulta para o meio exterior (Figura 6a), as larvas são alimentadas duas vezes por semana 22,6 $\pm 1 \mathrm{mg}$ de ração para peixe TetraMin® triturada.

O cultivo da espécie Allonais inaequalis é realizado em bandejas de plásticos (dimensões 25x30 cm - Figura 6b) utilizando aeração constante e alimentação uma vez por semana com $5 \pm 1 \mathrm{mg}$ de ração de peixe TetraMin ${ }^{\circledR}$ triturada. O meio é mantido com água sem cloro e aproximadamente $0,6 \mathrm{~cm}$ de sedimento passado na mufla seguindo recomendações de Corbi et al. (2015). O cultivo de Pristina longiseta se mantém em 
recipientes plásticos redondos de $500 \mathrm{ml}$, envoltos por papel toalha para o impedimento de entrada excessiva de luminosidade (Figura 6d) devido à espécie ter melhor adaptação em ambientes mais escuros (CASTRO et al., 2020). Os recipientes são constituídos da mesma areia tratada (areia fina, 4 horas na mufla a 550 graus), preenchidos com água livre de cloro, deixando-se o espaço de 3 centímetro da borda e mantidos a aeração constante.

O cultivo de Ceriodaphnia silvestrii é feito em béqueres de vidro de 1 litros (cerca de 80 organismos por béquer) e coberto com plástico filme para impedir a entrada de outros organismos no béquer (Figura 6c). O meio de cultivo é trocado três vezes por semana e é composto por água reconstituída, de $20 \mathrm{~mL} / \mathrm{L}$ de solução de sulfato de cálcio dihidratado em água deionizada e $10 \mathrm{~mL} / \mathrm{L}$ da solução de cloreto de potássio, bicarbonato de sódio e sulfato de magnésio heptahidratado em água deionizada, conforme a norma técnica NBR 13373 (ABNT - ASSOCIAÇÃO BRASILEIRA DE NORMAS TÉCNICAS, 2017). Para suplementação dos organismos são adicionadas a vitamina Sera Fishtamin® (1 gota a cada $2 \mathrm{~L}$ de água reconstituída). A alimentação do cultivo é realizada a cada troca do meio e consiste em suspensão algácea de Raphidocelis subcapitata (3x10-5 células.m/L) e aditivo alimentar $(1 \mathrm{~mL} / \mathrm{L})$. O aditivo alimentar é constituído de $50 \mathrm{~mL}$ de solução fermentada $(0,25 \mathrm{~g}$ de fermento biológico a cada $50 \mathrm{~mL}$ de água deionizada) e $50 \mathrm{~mL}$ de solução de ração de peixe ( $5 \mathrm{~g}$ de diluídos em um litro de água deionizada.

Figura 6 - Cultivos mantidos no Laboratório de Ecologia de Ambientes Aquáticos; a) Chironomus sancticaroli; b) Allonais inaequalis; c) Ceriodaphnia silvestrii; d) Pristina longiseta

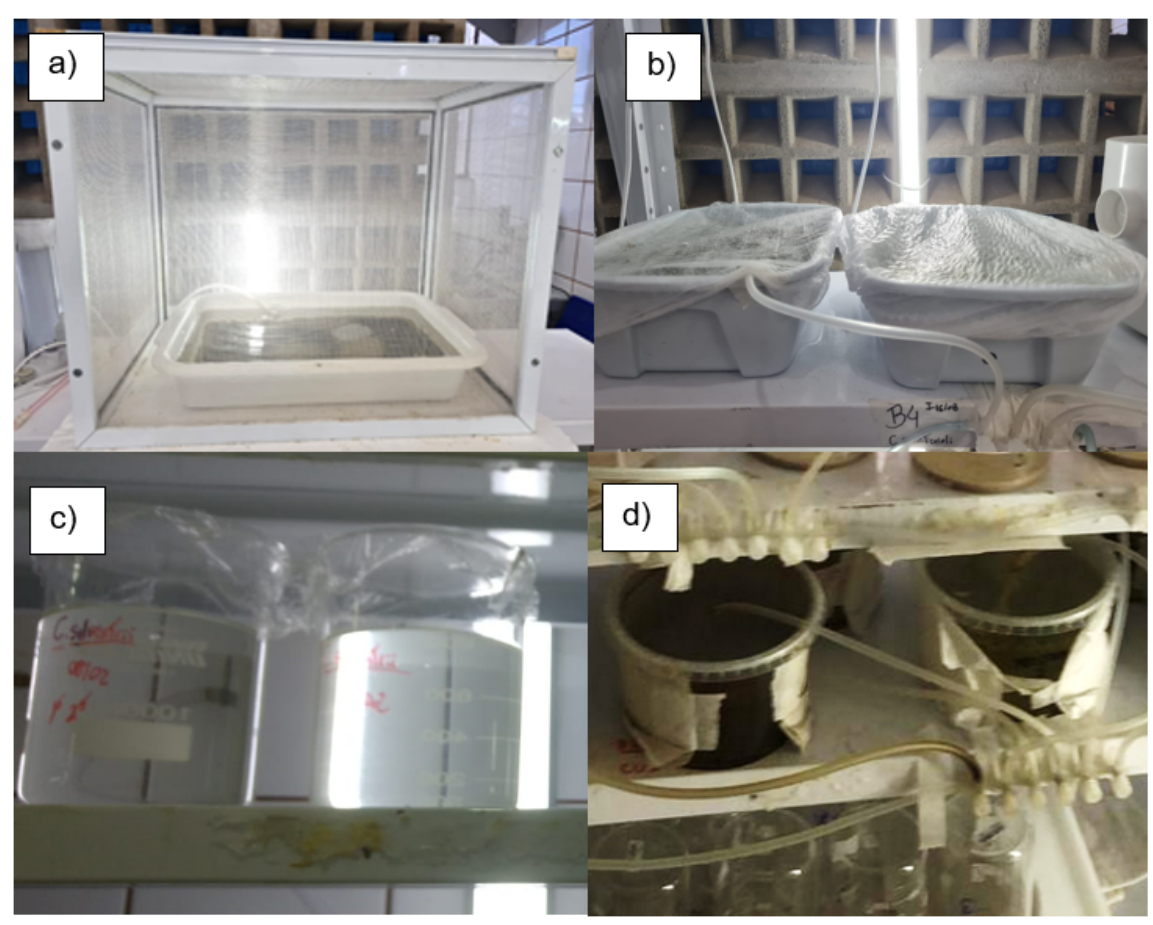

Fonte: Acervo pessoal (2021) 


\subsection{Testes de sensibilidade}

Com a finalidade de avaliar a saúde dos organismos, o seu potencial em apresentar respostas constantes e ainda verificar a estabilidade de determinado lote de indivíduos, bioensaios com substâncias de referência foram aplicados periodicamente, em paralelo com os bioensaios da pesquisa, seguindo o formato apresentado na Tabela 7 .

Tabela 7 - Composição e parâmetros utilizados para a realização dos testes de sensibilidade

\begin{tabular}{|c|c|c|c|c|}
\hline $\begin{array}{l}\text { Substância de } \\
\text { referência }\end{array}$ & $\begin{array}{l}\text { Allonais ina- } \\
\text { equalis } \\
\mathrm{KCl}\end{array}$ & $\begin{array}{l}\text { Pristina lon- } \\
\text { giseta } \\
\mathrm{KCl}\end{array}$ & $\begin{array}{l}\text { Ceriodaphnia } \\
\text { silvestrii } \\
\mathrm{NaCl}\end{array}$ & $\begin{array}{l}\text { Chironomus } \\
\text { sancticaroli } \\
\mathrm{KCl}\end{array}$ \\
\hline Volume & $100 \mathrm{~mL}$ & $60 \mathrm{~mL}$ & $30 \mathrm{~mL}$ & $250 \mathrm{~mL}$ \\
\hline $\begin{array}{l}\text { Sedimento } \\
\text { (areia muflada) }\end{array}$ & $10 \mathrm{~g}$ & $10 \mathrm{~g}$ & - & $50 \mathrm{~g}$ \\
\hline $\begin{array}{l}\text { Quantidade de } \\
\text { organismos }\end{array}$ & 6 & 6 & $\begin{array}{l}10 \text { neonatos } \\
\text { com menos de } \\
24 \mathrm{~h} \text { de vida }\end{array}$ & $\begin{array}{l}6 \text { larvas III ou } \\
\text { IV instar }\end{array}$ \\
\hline Exposição & $96 \mathrm{~h}$ & $48 \mathrm{~h}$ & $48 \mathrm{~h}$ & $96 \mathrm{~h}$ \\
\hline $\begin{array}{l}\text { Número de ré- } \\
\text { plicas }\end{array}$ & 3 & 3 & 2 & 3 \\
\hline Temperatura & 23 a $27^{\circ} \mathrm{C}$ & 23 a $27^{\circ} \mathrm{C}$ & 23 a $27^{\circ} \mathrm{C}$ & 23 a $27^{\circ} \mathrm{C}$ \\
\hline Fotoperíodo & $\begin{array}{l}12 \mathrm{~h} \mathrm{luz} / 12 \mathrm{~h} \\
\text { escuro }\end{array}$ & $\begin{array}{l}12 \mathrm{~h} \text { luz/12 h } \\
\text { escuro }\end{array}$ & $\begin{array}{l}12 \mathrm{~h} \mathrm{luz} / 12 \mathrm{~h} \\
\text { escuro }\end{array}$ & $\begin{array}{l}12 \mathrm{~h} \mathrm{luz} / 12 \mathrm{~h} \\
\text { escuro }\end{array}$ \\
\hline Alimentação & $\begin{array}{l}2 \mathrm{mg} \text { apenas no } \\
\text { início }\end{array}$ & $\begin{array}{l}2 \mathrm{mg} \text { apenas no } \\
\text { início }\end{array}$ & - & $\begin{array}{l}2 \mathrm{mg} \text { apenas no } \\
\text { início }\end{array}$ \\
\hline Resposta & Mortalidade & Mortalidade & Imobilidade & Mortalidade \\
\hline Metodologia & $\begin{array}{l}\text { Corbi, Gorni e } \\
\text { Correa (2015) }\end{array}$ & $\begin{array}{l}\text { Castro et al. } \\
(2020)\end{array}$ & $\begin{array}{l}\text { ABNT NBR } \\
12713: 2016\end{array}$ & $\begin{array}{l}\text { OECD 235: } \\
\text { 2011, Fonseca } \\
(1997)\end{array}$ \\
\hline
\end{tabular}

Fonte: Próprio do autor (2021)

As concentrações de KCL utilizados para Chironomus sancticaroli e Allonais inaequalis são de 0 (controle - apenas água sem cloro e alimento) e de 2 a 10 g/L. Para $P$. longiseta o gradiente de concentrações usando o KCL foi de 0 (controle), 0,75 a 2,5 g/L. Para $C$. silvestrii o gradiente de concentrações utilizado no teste de sensibilidade vai de 0 (controle), 0,25 a $3 \mathrm{~g} / \mathrm{L}$ de $\mathrm{NaCl}$. As substâncias de referência são preparadas no dia anterior ao teste e armazenadas em frascos âmbar a temperatura entre $5^{\circ} \mathrm{C}$ e $10^{\circ} \mathrm{C}$.

Os valores de sobrevivência obtidos para cada organismo foram transformados em valores de $\mathrm{CL}_{50}$ e plotados em gráfico que indica o limite de sensibilidade do organismo 
à presença de substâncias de referência já registrado em carta-controle estabelecida pelo LEAA em anos anteriores. Ressalta-se que a carta-controle dos organismos C. silvestrii e $P$. longiseta ainda estão em processo de estabelecimento.

\subsection{Testes de toxicidade aguda}

Os bioensaios de toxicidade aguda foram aplicados utilizando os organismos Allonais inaequalis, Pristina longiseta, Chironomus sancticaroli e Ceriodaphnia Silvestrii para avaliar a o nível de letalidade das amostras-alvo de pesquisa para os respectivos organismos. Os detalhes da composição dos testes estão apresentados na Tabela 8 para cada espécie.

Tabela 8 - Composição e parâmetros utilizados para a realização dos testes de toxicidade aguda

\begin{tabular}{|c|c|c|c|c|}
\hline Condição & $\begin{array}{l}\text { Allonais ina- } \\
\text { equalis }\end{array}$ & $\begin{array}{l}\text { Pristina lon- } \\
\text { giseta }\end{array}$ & $\begin{array}{l}\text { Ceriodaphnia } \\
\text { silvestrii }\end{array}$ & $\begin{array}{l}\text { Chironomus } \\
\text { sancticaroli }\end{array}$ \\
\hline $\begin{array}{l}\text { № de organis- } \\
\text { mos por réplica }\end{array}$ & 6 & 6 & $\begin{array}{l}10 \text { neonatos } \\
\text { com menos de } \\
24 \mathrm{~h} \text { de vida }\end{array}$ & $\begin{array}{l}6 \text { larvas III ou } \\
\text { IV instar }\end{array}$ \\
\hline $\begin{array}{l}\text { Tempo de ex- } \\
\text { posição }\end{array}$ & $96 \mathrm{~h}$ & $48 \mathrm{~h}$ & $48 \mathrm{~h}$ & $96 \mathrm{~h}$ \\
\hline Temperatura & $25 \pm 2^{\circ} \mathrm{C}$ & $25 \pm 2{ }^{\circ} \mathrm{C}$ & $25 \pm 2{ }^{\circ} \mathrm{C}$ & $25 \pm 2{ }^{\circ} \mathrm{C}$ \\
\hline $\begin{array}{l}\text { Sedimento } \\
\text { (areia muflada) }\end{array}$ & $10 \mathrm{~g}$ & $10 \mathrm{~g}$ & - & $50 \mathrm{~g}$ \\
\hline $\begin{array}{l}\text { Volume de } \\
\text { solução-teste }\end{array}$ & $70 \mathrm{~mL}$ & $60 \mathrm{~mL}$ & $30 \mathrm{~mL}$ & $200 \mathrm{~mL}$ \\
\hline $\begin{array}{l}\text { Volume do bé- } \\
\text { quer }\end{array}$ & $100 \mathrm{ml}$ & $100 \mathrm{ml}$ & $50 \mathrm{ml}$ & $500 \mathrm{ml}$ \\
\hline Alimentação & $\begin{array}{l}2 \mathrm{mg} \text { apenas no } \\
\text { início }\end{array}$ & $\begin{array}{l}2 \mathrm{mg} \text { apenas no } \\
\text { início }\end{array}$ & - & $\begin{array}{l}2 \mathrm{mg} \text { apenas no } \\
\text { início }\end{array}$ \\
\hline Fotoperíodo & $\begin{array}{l}12 \mathrm{~h} \mathrm{luz} / 12 \mathrm{~h} \\
\text { escuro }\end{array}$ & $\begin{array}{l}12 \mathrm{~h} \mathrm{luz} / 12 \mathrm{~h} \\
\text { escuro }\end{array}$ & $\begin{array}{l}12 \mathrm{~h} \mathrm{luz} / 12 \mathrm{~h} \\
\text { escuro }\end{array}$ & $\begin{array}{l}12 \mathrm{~h} \text { luz } / 12 \mathrm{~h} \\
\text { escuro }\end{array}$ \\
\hline Resposta & Sobrevivência & Sobrevivência & Mobilidade & Sobrevivência \\
\hline $\begin{array}{l}\text { Número de ré- } \\
\text { plicas }\end{array}$ & 3 & 3 & 3 & 3 \\
\hline $\begin{array}{l}\text { Número de tra- } \\
\text { tamentos }\end{array}$ & $\begin{array}{l}10 \text { diluições + } \\
\text { controle }\end{array}$ & $\begin{array}{l}10 \text { diluições }+ \\
\text { controle }\end{array}$ & $\begin{array}{l}10 \text { diluições }+ \\
\text { controle }\end{array}$ & $\begin{array}{l}10 \text { diluições + } \\
\text { controle }\end{array}$ \\
\hline Metodologia & $\begin{array}{l}\text { Corbi, Gorni e } \\
\text { Correa }(2015)\end{array}$ & $\begin{array}{l}\text { Castro et al. } \\
(2020)\end{array}$ & $\begin{array}{l}\text { ABNT NBR } \\
12713: 2016\end{array}$ & $\begin{array}{l}\text { OECD 235: } \\
\text { 2011, Fonseca } \\
(1997)\end{array}$ \\
\hline
\end{tabular}

Fonte: Próprio do autor (2021)

O volume das soluções-teste para os organismos $A$. inaequalis, $P$. longiseta e $C$. 
sancticaroli foram adaptados para que houvesse um aproveitamento de amostra e fosse evitado a geração de volume de descartes. Ao final da montagem de cada teste os béqueres foram cobertos com plástico filme para que não houvesse interferência do meio nas amostras, para Chironomus sancticaroli foram colocados tela de tule para evitar a saída dos adultos em caso de emergência. Todos os organismos foram selecionados seguindo os critérios sugeridos nas metodologias com cautela na retirada e colocação dos organismos em meioteste, para que fosse evitado níveis elevados de estresse aos animais, com pipetas Pasteur de vidro ou de plástico, liberando os indivíduos abaixo do nível da água. O esquema de montagem do teste pode ser observado na Figura 7.

Figura 7 - Esquema de montagem de teste de toxicidade aguda

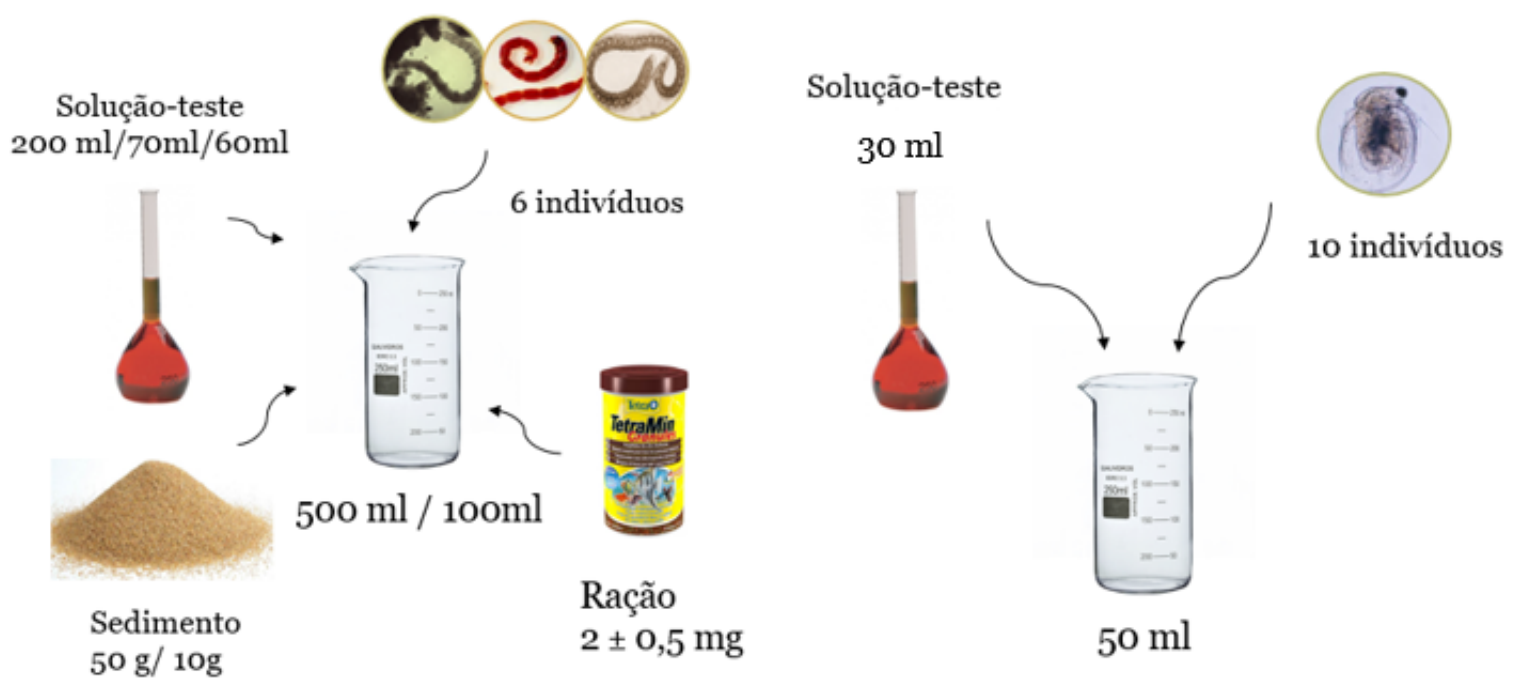

Fonte: Acervo pessoal (2021)

Ao término da montagem do teste, os parâmetros $\mathrm{pH}$, condutividade elétrica e oxigênio dissolvido foram medidos com sonda multiparâmetros da marca AKSO modelo AK88 em duas réplicas, o mesmo procedimento foi observado ao final do teste. Concluídos o tempo de teste para cada espécie, os béqueres foram removidos e os organismos foram contados. Quando necessário, se utilizou o microscópio estereoscópio para a melhor visualização dos indivíduos, eles foram registrados e o remanescente de material (areia e meio de teste) foram armazenados para posterior descarte, caso fosse necessário. Na Figura 8, observa-se os registros fotográficos dos testes realizados com os 4 invertebrados aquáticos.

\subsection{Testes de toxicidade crônica}

Para avaliar os efeitos subletais das amostras-alvo o organismo C. sancticaroli foi selecionada devido à sua multiplicidade em repostas, facilidade de manutenção e realização 
Figura 8 - Testes de toxicidadde aguda realizados com os organismos-teste a) Chironomus sancticaroli; b) Pristina longiseta; c) Allonais inaequalis; d) Ceriodaphnia silvestrii.

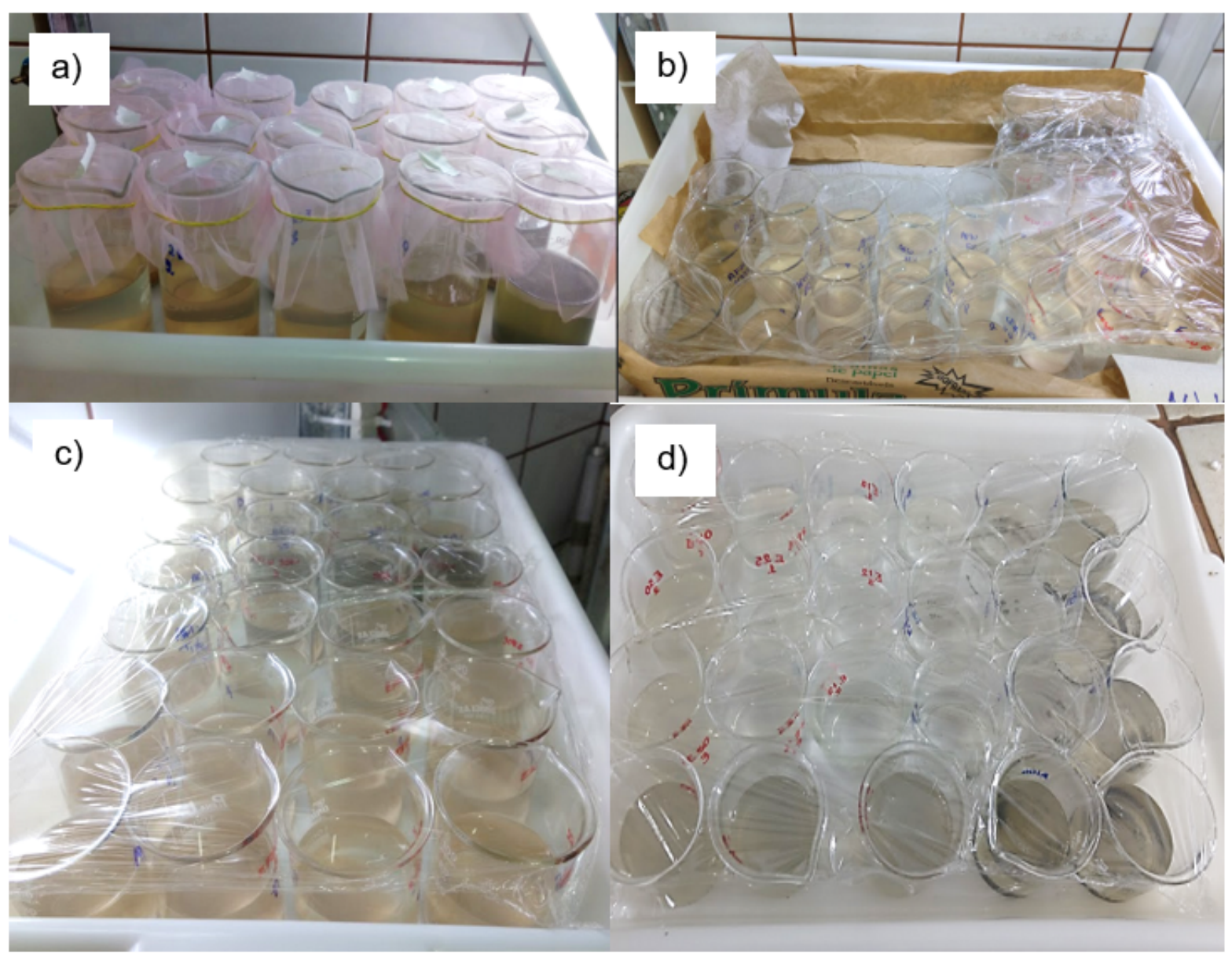

Fonte: Acervo pessoal (2021)

de testes, além da frequente presença nos corpos receptores de São Carlos. No teste de toxicidade de longa duração para a espécie Chironomus sancticaroli, as preparações e condições metodológicas seguiram as premissas estabelecidas por Bernegossi et al. (2019), conforme indicado na Tabela 9.

Os béqueres foram envolvidos com tecido tule liso em sua abertura superior, atados com elástico látex, para o acoplamento das mangueiras de aeração, para evitar a possível fuga de indivíduos emergidos, conforme pode ser observado na Figura 9. A alimentação foi realizada com quantidade de $2 \mathrm{mg}$ de ração para peixes TetraMin® e aeração constante.

Após completadas as $240 \mathrm{~h}$ de teste todas as larvas foram fixadas em álcool isopropílico, para a medição do comprimento das larvas, que foram posteriormente alocadas em lâmina de vidro com papel milimetrado posicionado atrás da lâmina e fotografadas utilizando dispositivo eletrônico pessoal, conforme o apresentado na Figura 10ac. Após o registro fotográfico dos indivíduos, as medidas de cada organismo foram identificadas 
Tabela 9 - Composição e parâmetros utilizados para a realização dos testes de toxicidade crônica.

\begin{tabular}{cc}
\hline Condição & Chironomus sancticaroli \\
\hline \hline № de organismos por réplica & 20 larvas de $1^{\mathrm{o}}$ ínstar \\
\hline Tempo de exposição & $240 \mathrm{~h}$ \\
\hline Temperatura & $25 \pm 2^{\circ} \mathrm{C}$ \\
\hline Sedimento (areia muflada) & $60 \mathrm{~g}$ \\
\hline Volume de solução-teste & $500 \mathrm{~mL}$ \\
\hline Volume do béquer & $1000 \mathrm{ml}$ \\
\hline Alimentação & $2 \mathrm{mg}$ apenas no início \\
\hline Fotoperíodo & $12 \mathrm{~h}$ luz $/ 12 \mathrm{~h}$ escuro \\
\hline Resposta & Sobrevivência, comprimento larval e deformidades bucais \\
\hline Número de réplicas & 1 (20 indivíduos $)$ \\
\hline Número de tratamentos & 10 diluições + controle \\
\hline Metodologia & Bernegossi et al. $(2019)$ \\
\hline
\end{tabular}

Fonte: Próprio do autor (2021)

Figura 9 - Teste de toxicidadde crônica utilizando o inseto aquático Chironomus sancticaroli

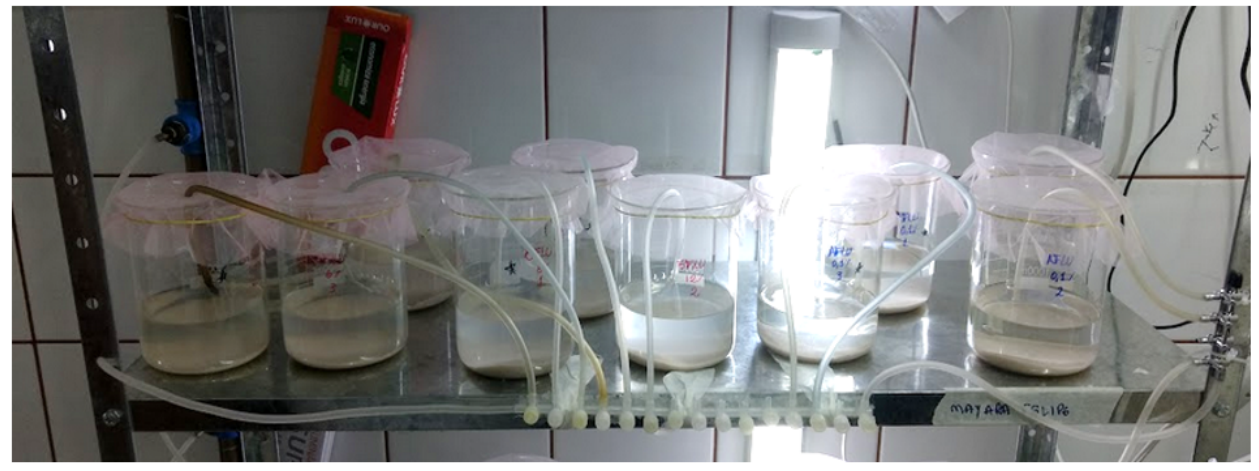

Fonte: Acervo pessoal (2021)

através do software IMAGEJ, os organismos foram posteriormente alocados em placa de petri para a remoção das capsulas cefálica com o auxílio de um microscópio estereoscópio.

Após a remoção das capsulas cefálicas, elas foram fixadas em lâminas com meio de Hoyer com o lado central da cápsula posicionado para cima. Com auxílio de microscópio óptico modelo Nikon ECLIPSE E200 (Figura 10c) e do software TSView, imagens foram registradas (Figura 10b) e foram avaliadas eventuais deformidades bucais dos indivíduos. A identificação de deformidades foi determinada comparando-se os resultados de deformidade 
Figura 10 - Ferramentas e registros obtidos por meio do teste de toxicidadde crônica realizado utilizando o inseto aquático Chironomus sancticaroli; a) larvas coletadas para a medição de comprimento; b) cápsula cefálica observada em microscópio e c) Microscópio utilizado com câmera conectada a computador

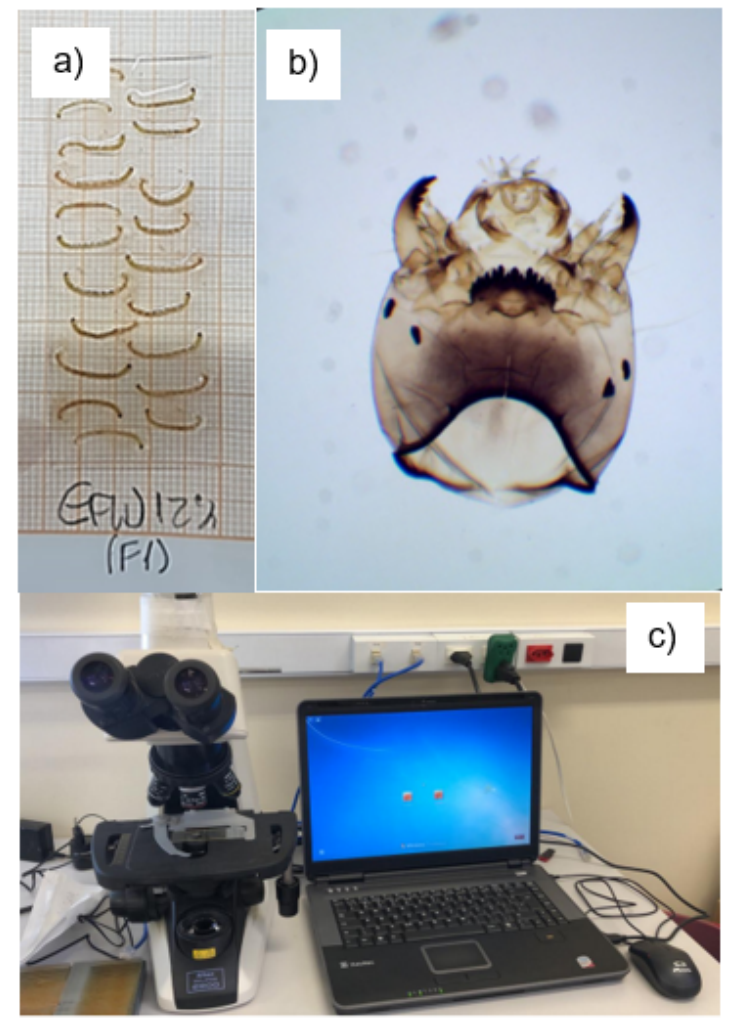

Fonte: Acervo pessoal (2021)

mandibular de vários trabalhos (AL-SHAMI et al., 2010; BENEBERU; MENGISTOU, 2015) em especial o levantamento, e modelo de tabela, feito por Pinto et al. (2021a), que avaliaram 5 tipos de deformidades em lavas de Chironomus sancticaroli expostos a pesticidas, que são o vão de Köehn (ou espaço entre os dentes), ausência de dente, dentes sobrando, sem dentes e dentes degastados, com exemplos identificados na Figura 11.

\subsection{Substâncias-teste}

\subsubsection{Afluente e Efluente do RALF}

O Reator de Leito Fluidificado (RALF) em escala piloto foi instalado na Estação de Tratamento de Águas Residuais de São Carlos (ETE Monjolinho), e foi um dos projetos de pesquisa desenvolvidos pelo Laboratório de Processos Biológicos (LPB) englobados pelo projeto temático FAPESP n⿳⺈ 2015/06246-7, ele foi operado e estudado pela doutoranda Luciana Pirete entre o período de março de 2020 até março de 2021.

Os resultados obtidos para a eficiência de remção de matéria orgânica, remoção de 
Figura 11 - Deformidades mais comuns encontradas no mentos de lavas de Chironomus sancticaroli; a) configuração normal; b) Vão de Köehn; c) dentes extras; d) ausência de dente; e) Sem dentes e f) dentes desgastados
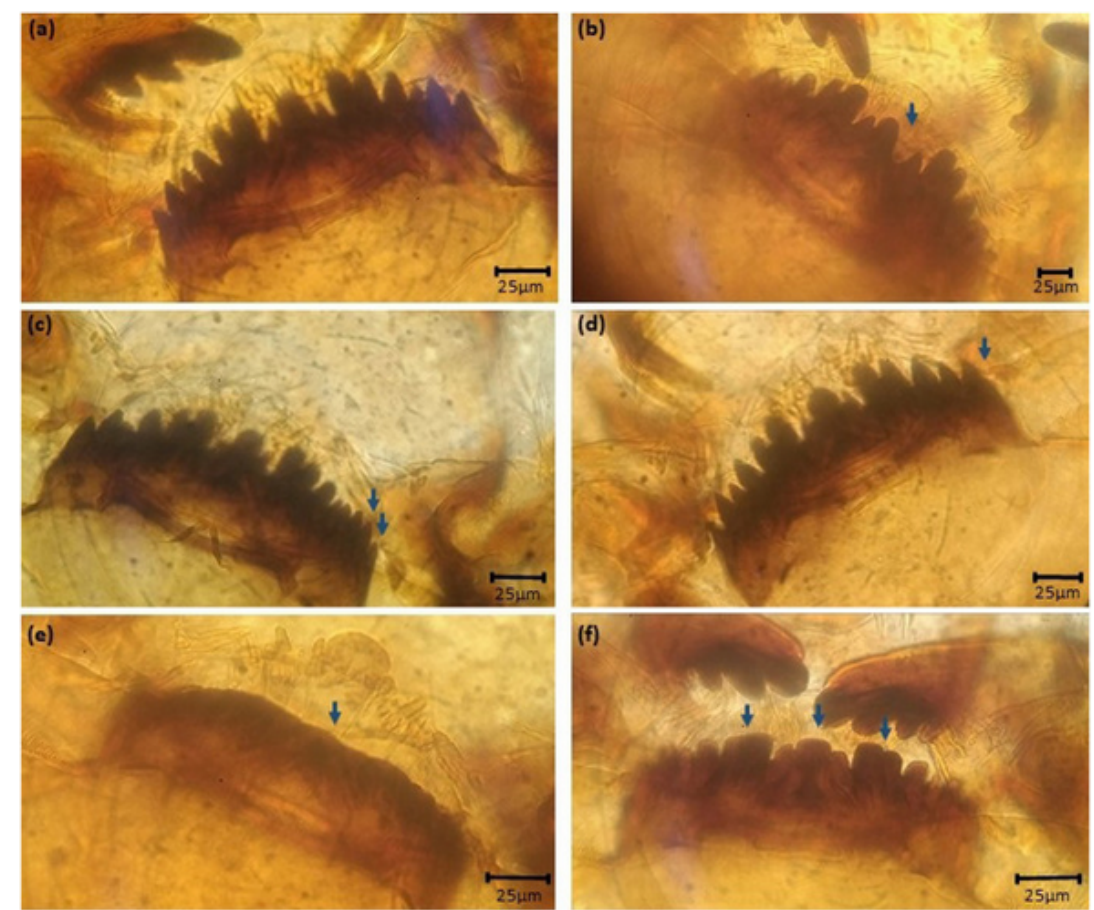

Fonte: Pinto et al. (2021a)

fármacos, bem como o detalhamento técnico serão disponibilizados em breve no banco de teses da USP através do trabalho escrito pela mesma. O objetivo principal do RALF foi avaliar a sua eficiência, em diferentes tempos de detenção hidráulica (TDH), com co-substrato, na remoção de Nitrato e dos fármacos diclofenaco (DCF) e ibuprofeno (IBU). Para esse propósito, adicionou-se uma injeção inicial desses fármacos $(100 \mu \mathrm{g} / \mathrm{L}$ de diclofenaco e $150 \mu \mathrm{g} / \mathrm{L}$ de ibuprofeno) e de Nitrato $(180 \mathrm{mg} / \mathrm{L})$, para a garantia de quantidade mínima de substância para o tratamento. O reator foi operado em 3 fases, com o etanol como co-substrato $(100 \mathrm{mg} / \mathrm{L})$ e na Fase III a injeção de nitrato foi retirada. Os tempos de detenção hidráulica testados (TDH) serão 18h, 12h e 18h novamente, conforme indicado na Tabela 10.

Em cada fase de operação do reator foram feitas análises de DQO, alcalinidade, pH, Ácidos Voláteis Totais e concentração de fármacos, sendo diariamente avaliados o DQO, pH e nitrato, dados estes que serão publicados posteriormente pela pesquisadora citada anteriormente. O reator foi considerado estável quando a matéria orgânica se manteve constante num espaço de tempo de 5 dias, só então a amostra foi coletada, num volume aproximado de 4 litros de afluente e efluente em garrafas plásticas para a realização dos testes de toxicidade. 
Tabela 10 - Operação e configuração do RALF

\begin{tabular}{|c|c|c|c|c|c|c|}
\hline Fase & Operaçãc & & $T D H$ & Fármacos & & Aditivos \\
\hline Adaptação & $\begin{array}{l}\mathrm{Mar} / 20 \\
\mathrm{Jul} / 20\end{array}$ & $\mathrm{a}$ & - & - & & - \\
\hline I & $\begin{array}{l}\mathrm{Jul} / 20 \\
\text { Set } / 20\end{array}$ & $\mathrm{a}$ & $18 \mathrm{~h}$ & $\begin{array}{l}100 \mu \mathrm{g} / \mathrm{L} \\
150 \mu \mathrm{g} / \mathrm{L} \text { IBU }\end{array}$ & $\mathrm{DCF}$ & $\begin{array}{l}100 \mathrm{mg} / \mathrm{L} \text { etanol e } 180 \\
\mathrm{mg} / \mathrm{L} \text { Nitrato }\end{array}$ \\
\hline II & $\begin{array}{l}\text { Out } / 20 \\
\text { Jan } / 21\end{array}$ & $\mathrm{a}$ & $12 \mathrm{~h}$ & $\begin{array}{l}100 \mu \mathrm{g} / \mathrm{L} \\
150 \mu \mathrm{g} / \mathrm{L} \text { IBU }\end{array}$ & $\mathrm{DCF}$ & $\begin{array}{l}100 \mathrm{mg} / \mathrm{L} \text { etanol e } 180 \\
\mathrm{mg} / \mathrm{L} \text { Nitrato }\end{array}$ \\
\hline III & $\begin{array}{l}\text { Jan/21 } \\
\text { Mar/21 }\end{array}$ & a & $18 \mathrm{~h}$ & $\begin{array}{l}100 \mu \mathrm{g} / \mathrm{L} \\
150 \mu \mathrm{g} / \mathrm{L} \text { IBU }\end{array}$ & $\mathrm{DCF}$ & $100 \mathrm{mg} / \mathrm{L}$ etanol \\
\hline
\end{tabular}

Fonte: Próprio do autor (2021)

Na fase I, para o desenvolvimento do teste crônico com Chironomus sancticaroli, uma segunda amostra do efluente foi coletada ainda na fase estabilizada do reator. $\mathrm{O}$ afluente considerado neste trabalho é referente ao esgoto doméstico bruto municipal após tratamento preliminar (retirada de materiais grosseiros e desarenação) e o efluente referente a amostra líquida pós-tratamento do RALF. O desenho esquemático do reator e seus pontos de coleta estão expressos na Figura 12 e o reator em imagem real instalado na ETE na Figura 13.

Figura 12 - Desenho esquemático do RALF e pontos de coleta

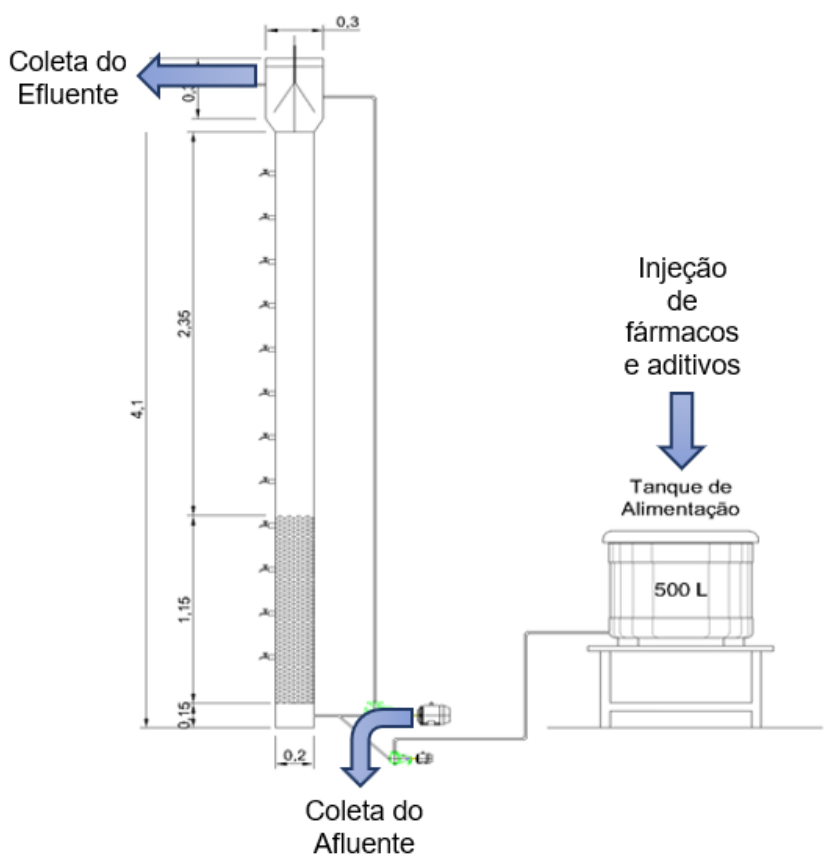

Fonte: Gerosa (2016) 
Figura 13 - Registro fotográfico do RALF instalado na estação de tratamento

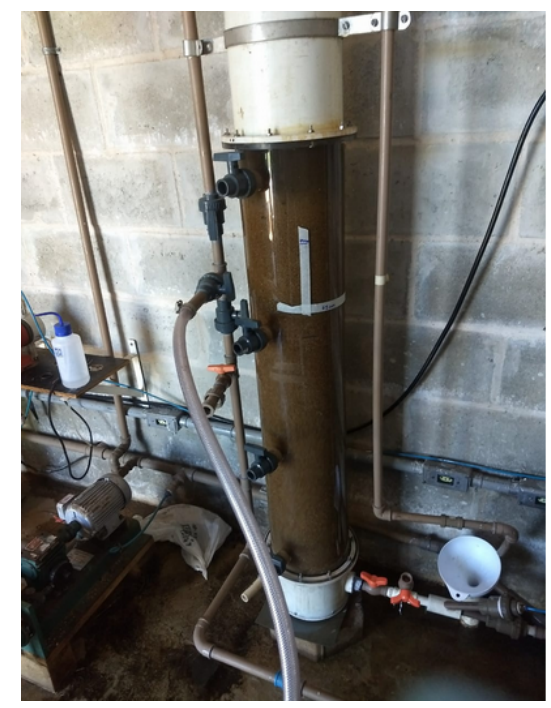

Fonte: Próprio do autor (2021)

O armazenamento da amostra foi feito em refrigerador a temperaturas abaixo de $10^{\circ} \mathrm{C}$ por até $48 \mathrm{~h}$. Em casos em que não houve a possibilidade de realização de ensaios com algum dos organismos assim que a amostra foi coletada, optou-se pelo armazenamento em refrigerador a temperaturas abaixo de $-10^{\circ} \mathrm{C}$ por um período máximo de 60 dias, período recomendado pela ABNT NBR 15469 (ABNT - ASSOCIAÇÃO BRASILEIRA DE NORMAS TÉCNICAS, 2007).

Para os testes de toxicidade de curta duração foram usadas as diluições estabelecidas por BERTOLETTI (2008), que variaram de $100 \%$ a $6 \%$ de fração de efluente ou afluente por tratamento. As frações estimadas para o ensaio de longa duração foram baseadas nos resultados dos testes de curta duração realizados com o RALF, com base nesses resultados optou-se por utilizar 5 frações, que variam de $12 \%$ a $0,1 \%$. A fração $0,1 \%$ foi selecionada baseando-se nos cálculos utilizando a equação de Streeter Phelps com a vazão real do efluente que sai da ETE Monjolinho e a vazão real do rio monjolinho no ponto de despejo, conforme apresentado detalhadamente por Felipe (2019). O quadro resumo contendo as diluições aplicadas se encontram na Tabela 11.

Tabela 11 - Frações de afluente e efluente aplicadas nos testes

\begin{tabular}{lllllll}
\hline $\begin{array}{l}\text { Teste curta dura- } \\
\text { ção }\end{array}$ & Controle & $100 \%$ & $50 \%$ & $25 \%$ & $12 \%$ & $6 \%$ \\
\hline $\begin{array}{l}\text { Teste longa dura- } \\
\text { ção }\end{array}$ & $12 \%$ & $6 \%$ & $3 \%$ & $1 \%$ & $0,1 \%$ \\
\hline
\end{tabular}

Fonte: Próprio do autor (2021) 
Todas as diluições foram realizadas em balão volumétrico com o triplo do volume de cada réplica com o objetivo de criar réplicas o mais exatas possíveis. O meio teste utilizado para os organismos A. inaequalis, P. longiseta e C. sancticaroli foram montados da mesma maneira, para tanto, o balão volumétrico de 1 litro foi suficiente para a montagem de todas as réplicas das 3 espécies evitando-se o desperdício de material. A imagem do gradiente visível da presença de afluente e efluente do esgoto pode ser observado na Figura 14.

Figura 14 - Exemplar de diluições aplicadas para a) afluente ao reator e b)efluente do reator

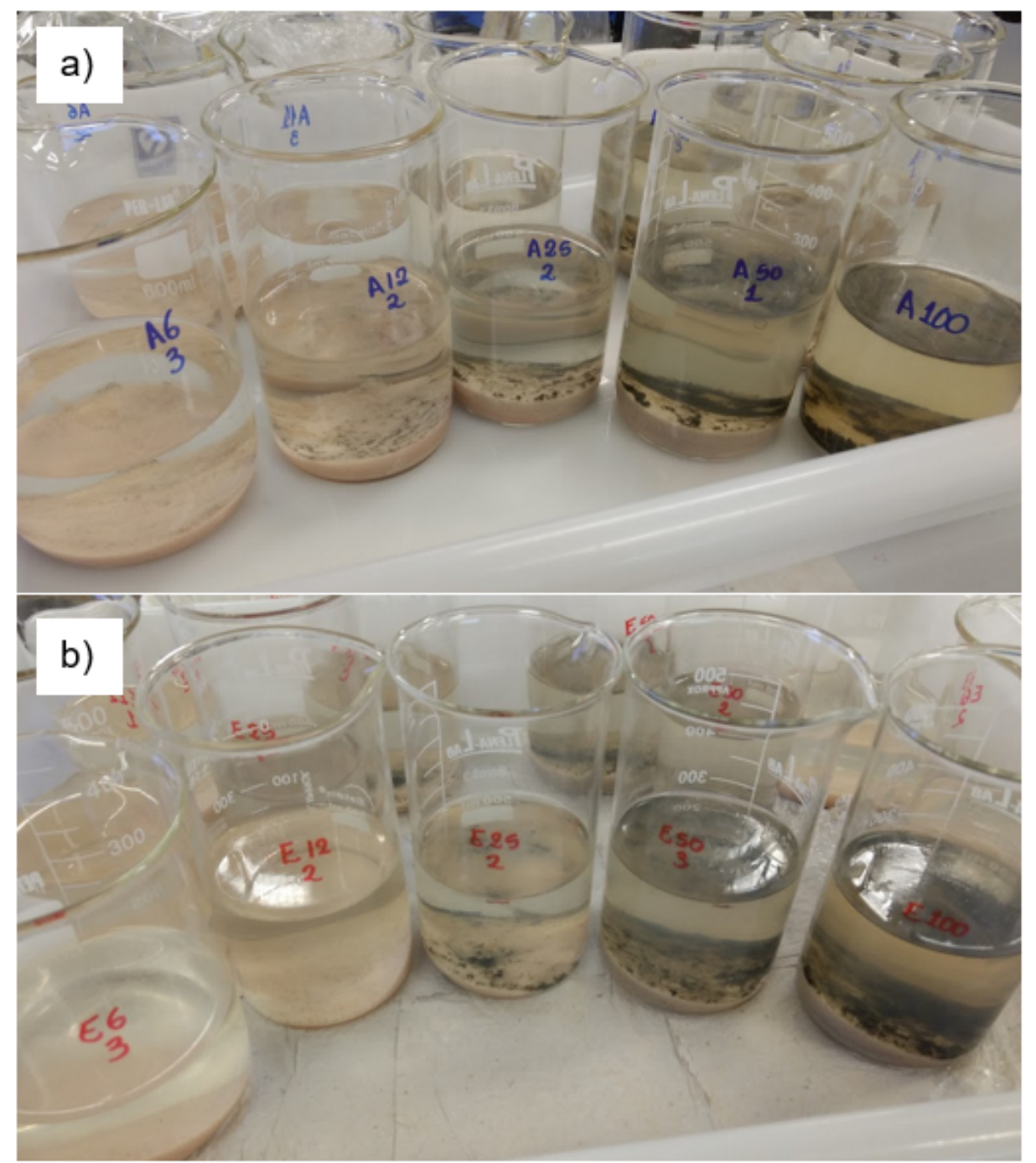

Fonte: Próprio do autor (2021)

Por último, a Figura 15 apresenta o resumo esquemático dos ensaios realizados com as amostras de efluente e afluente do RAlF com os tipos de teste, as respostas buscas e os objetivos de cada etapa. 
Figura 15 - Resumo esquemático da abordagem metodológica utilizando amostras do RALF

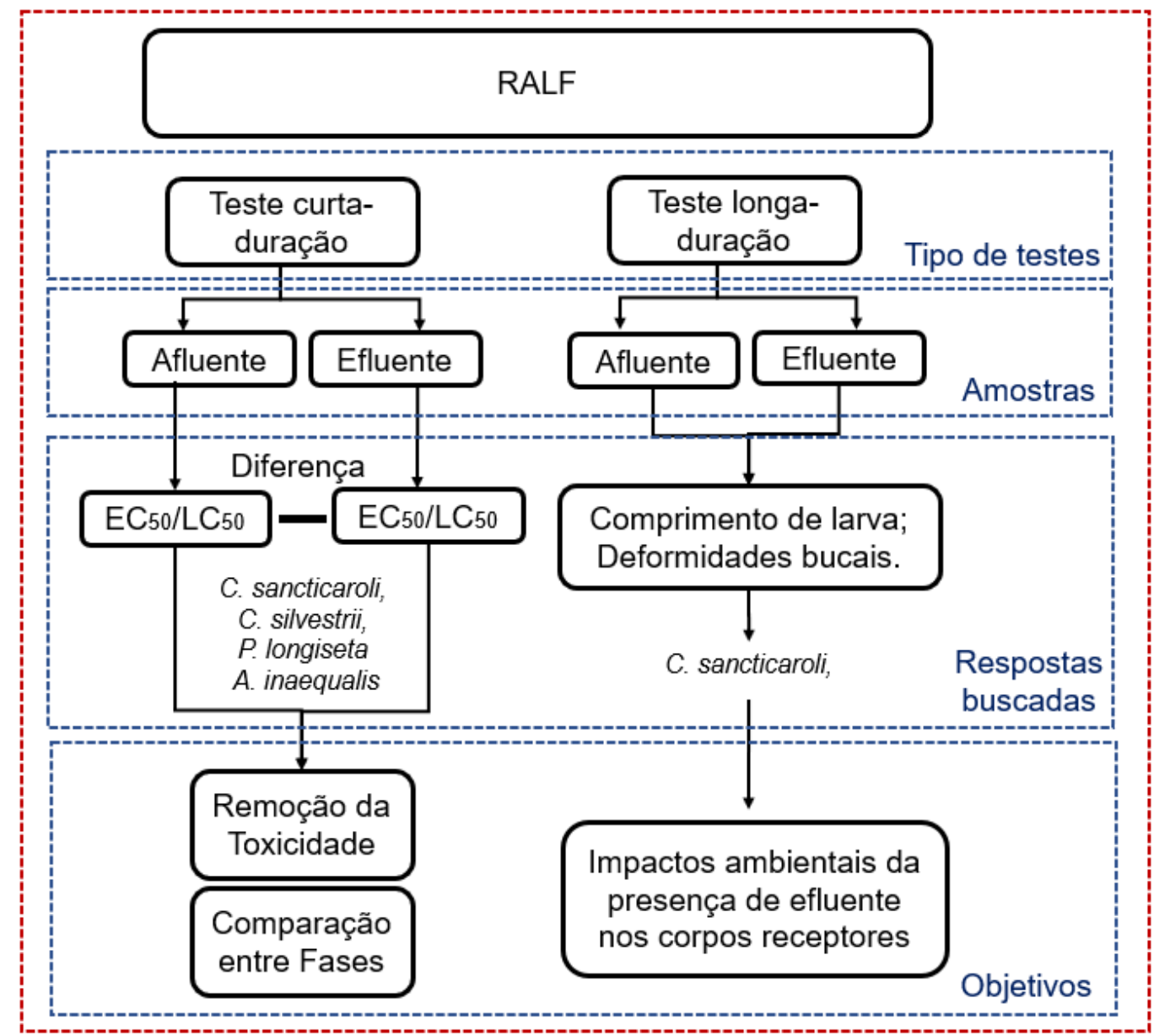

Fonte: Próprio do autor (2021)

\subsubsection{Diclofenaco de Potássio}

O Diclofenaco de Potássio em pó foi adquirido em farmácia de manipulação na cidade de Araraquara (São Paulo, BR), com pureza para consumo humano. A solução estoque (1,0 gDCF/L - nominal) foi preparada com $500 \mathrm{~mL}$ de água deionizada e 500mg de DCF, que foi conservado em frascos âmbar de 100mL (Figura 16) em temperatura entre 4 e $10{ }^{\circ} \mathrm{C}$ por um período de 4 meses (período de realização dos testes necessários.

As concentrações de partida para o melhor enquadramento do teste foram tomadas com base na revisão de literatura (Tabela 3) e nas concentrações utilizadas na entrada do $\operatorname{RALF}(100 \mu \mathrm{g} / \mathrm{L})$, foram estabelecidas entre $20 \mathrm{mg} / \mathrm{L}$ e $150 \mathrm{mg} / \mathrm{L}$. À medida que os organismos respondiam às concentrações, esse gradiente era alterado até que houvesse uma curva dose-reposta suavizada e numericamente graduada, conforme detalhamento apresentado na Tabela 12. A partir dessas concentrações o gradiente de concentrações foi estabelecido para cada organismo testado. A seleção do gradiente de concentração para o 
teste de toxicidade crônica foi fixada a partir dos resultados do teste de toxidade aguda e foram estabelecidos entre 0,10 e $1 \mathrm{mg} / \mathrm{L}$, abrangendo concentrações ambientalmente relevantes em águas superficiais $(0,12 \mathrm{mg} / \mathrm{L})$, em esgotos $(0,84 \mathrm{mg} / \mathrm{L})$ e se aproximando do valor de $\mathrm{CL}_{50}$ encontrado para Chironomus sancticaroli.

Figura 16 - Frasco usado para armazenamento da solução de diclofenaco

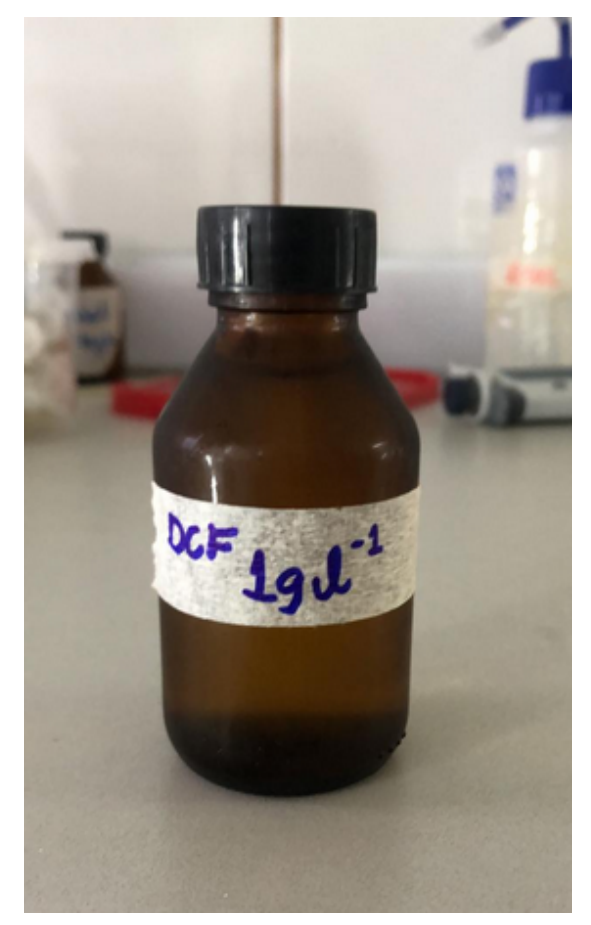

Fonte: Próprio do autor (2021)

Tabela 12 - Gradiente de concentrações aplicados para os testes de toxicidade aguda utilizadno o diclofenaco

\begin{tabular}{llll}
\hline $\begin{array}{c}\text { Allonais } \\
\text { inaequalis }\end{array}$ & $\begin{array}{l}\text { Pristina } \\
\text { longiseta }\end{array}$ & $\begin{array}{l}\text { Ceriodaphnia } \\
\text { silvestrii }\end{array}$ & $\begin{array}{l}\text { Chironomus } \\
\text { sancticaroli }\end{array}$ \\
\hline $60 \mathrm{mg} / \mathrm{L}$ & $10 \mathrm{mg} / \mathrm{L}$ & $12 \mathrm{mg} / \mathrm{L}$ & $0,25 \mathrm{mg} / \mathrm{L}$ \\
$70 \mathrm{mg} / \mathrm{L}$ & $30 \mathrm{mg} / \mathrm{L}$ & $24 \mathrm{mg} / \mathrm{L}$ & $0,5 \mathrm{mg} / \mathrm{L}$ \\
$80 \mathrm{mg} / \mathrm{L}$ & $50 \mathrm{mg} / \mathrm{L}$ & $36 \mathrm{mg} / \mathrm{L}$ & $1 \mathrm{mg} / \mathrm{L}$ \\
$90 \mathrm{mg} / \mathrm{L}$ & $70 \mathrm{mg} / \mathrm{L}$ & $48 \mathrm{mg} / \mathrm{L}$ & $2 \mathrm{mg} / \mathrm{L}$ \\
$100 \mathrm{mg} / \mathrm{L}$ & $90 \mathrm{mg} / \mathrm{L}$ & $60 \mathrm{mg} / \mathrm{L}$ & $4 \mathrm{mg} / \mathrm{L}$ \\
\hline
\end{tabular}

Fonte: Próprio do autor (2021)

A configuração do teste de toxicidade crônica utilizando o inseto Chironomus sancticaroli foi registrado e apresentada na Figura 17. Na Figura 18, apresenta-se o esquema resumo das abordagens, repostas buscadas e objetivos dos testes realizados utilizando diclofenaco. 
Figura 17 - Registro da configuração de teste de toxicidade crônica utilizando o diclofenaco

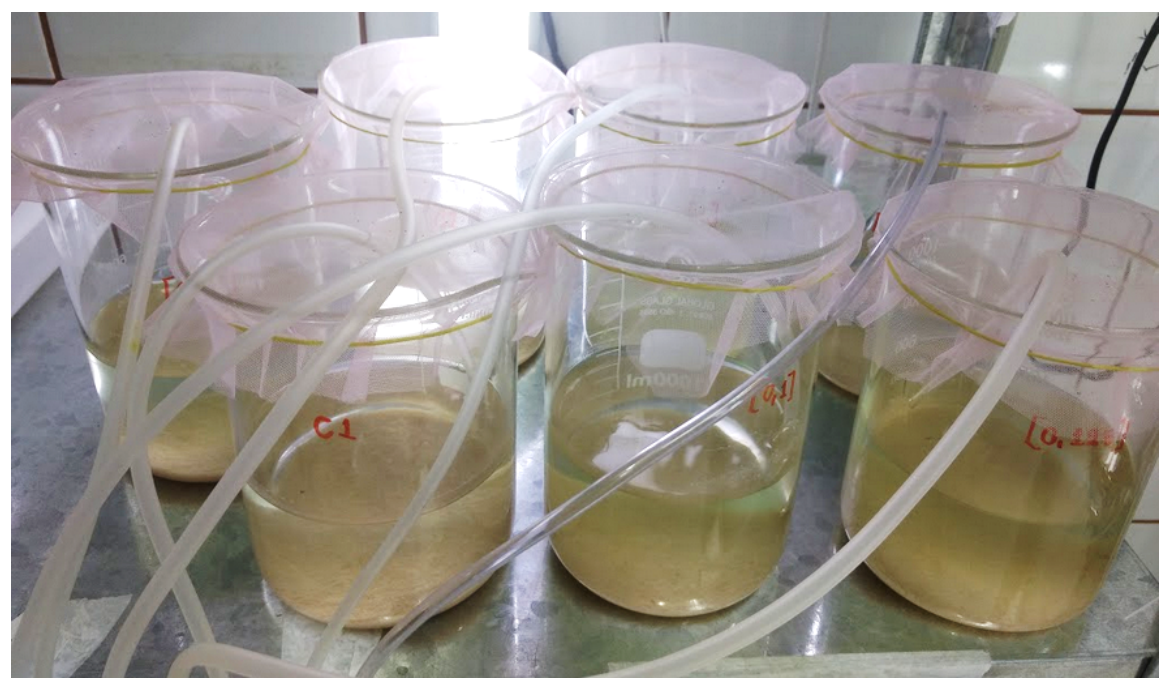

Fonte: Próprio do autor (2021)

Figura 18 - Resumo esquemático da abordagem metodológica utilizando o diclofenaco

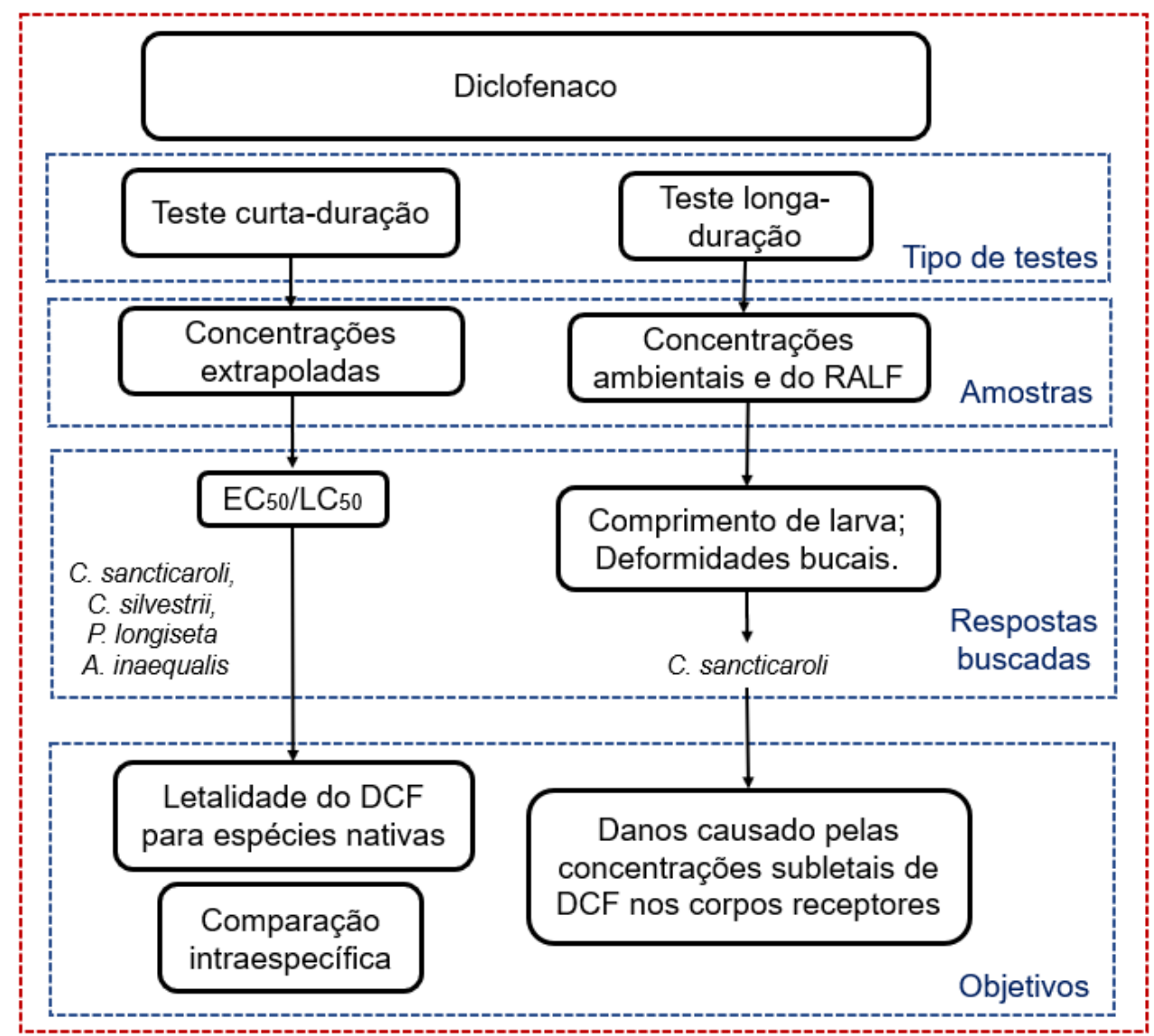

Fonte: Próprio do autor (2021) 


\subsection{Tratamento estatístico}

Os resultados obtidos a partir da finalização dos testes foram analisados quanto a sua normalidade através de inferências do teste Shapiro-Wilk e posteriormente trabalhados utilizando uma análise de variância (ANOVA ou Kruskal-wallis). Foram observados os valores da correlação de Pearson para resultados estatisticamente significantes $(\mathrm{p}<0,05)$, por meio do software Past versão 3.14. As concentrações letais para $50 \%$ da população submetida a teste $\left(\mathrm{CL}_{50}\right.$ e $\left.\mathrm{CE}_{50}\right)$, e no caso de efluentes, as frações letais ( $\mathrm{CL}_{50}$ e $\mathrm{CE}_{50}$ ), expresso em porcentagem de esgoto necessário para causar letalidade dos organismos, foram calculadas por meio do software $\mathrm{R}$ versão 3.5.2.

Através dos resultados obtidos no teste de curta duração utilizando amostras de efluente do RALF ( $\mathrm{CL}_{50}$ ou $\mathrm{CE}_{50}$ ) foram calculados os valores de Remoção de Toxicidade (RT), que é expresso em pontos percentuais (pp) de diferença entre a fração letal do enfluente e do afluente, conforme a equação abaixo, e plotados as curvas de distribuição de sensibilidade das espécies (SSD) através do software ETX versão 2.0.

$$
R T(p p)=C L(E)_{50} \text { afluente }-C L(E)_{50} \text { efluente }
$$




\section{RESULTADOS E DISCUSSÕES}

\subsection{Teste de sensibilidade}

Os resultados dos dados de Concentração letal e efetiva nos organismos, que afeta $50 \%$ da população, obtidos por meio dos ensaios de toxicidade utilizando as substâncias de referência Cloreto de Potássio $(\mathrm{KCl})$ e Cloreto de Sódio $(\mathrm{NaCl})$ estão discretizados na Figura 19. Os bioensaios foram realizados por todos os membros do LEAA.

Figura 19 - Resultado do teste de sensibilidade utilizando os organismo a) C. sancticaroli (KCl); b) A. inaequalis (KCl); c) C. silvestrii $(\mathrm{NaCl})$ e d) P. longiseta $(\mathrm{KCl})$.

a)

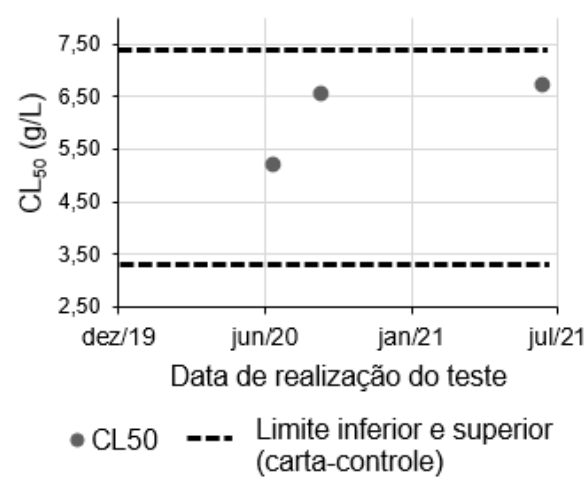

c)

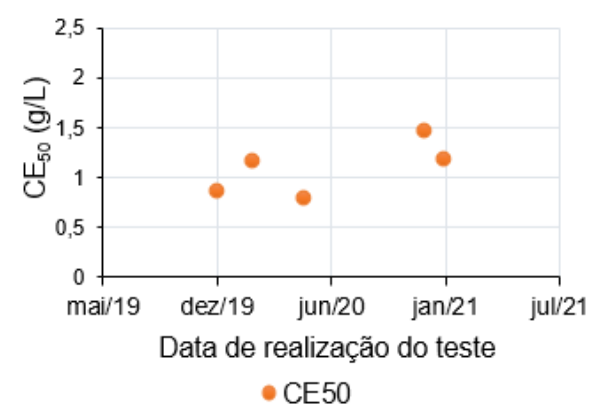

b)

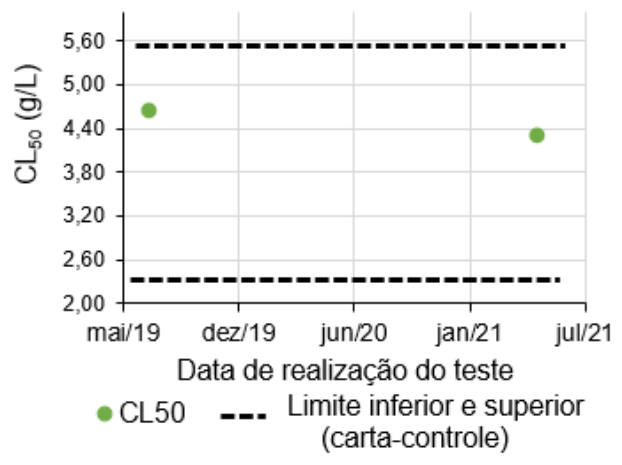

d)

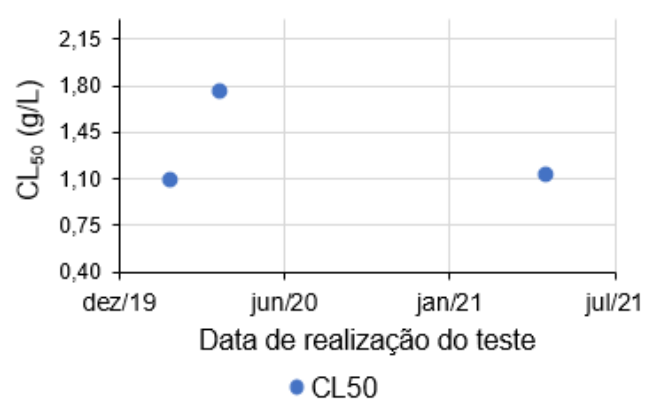

Fonte: Própria do autor (2021)

Pristina longiseta e Ceriodaphnia silvestrii por serem organismos de recente cultivo e manutenção no LEAA ainda não possuem carta-controle estabelecida, no entanto, a toxicidade de $\mathrm{P}$. longiseta ao $\mathrm{KCl}$ teve média de $1,32 \mathrm{~g} / \mathrm{L}$, o que fica próximo aos valores indicados por Castro et al. (2020) para essa espécie, de 1,76 g/L, enquanto a toxicidade média para $C$. silvestrii de $1,09 \mathrm{~g} / \mathrm{L}$ se aproxima do gradiente obtido por Mansano et al. (2018b) de 1,00 a 1,32 g/L, e do padrão de 1,00 a 1,83 g/L descrito por Casali-Pereira et 
al. (2015). Para Allonais inaequalis, a toxicidade média do $\mathrm{KCl}$ encontrada foi de 4,46 g/L, se enquadrando na faixa de sensibilidade esperada. Para o inseto Chironomus sancticaroli, a toxicidade aguda média ao $\mathrm{KCl}$ encontrada foi de $6,13 \mathrm{~g} / \mathrm{L}$, valor dentro da faixa de sensibilidade esperada.

Apesar da realização dos testes de sensibilidade ter sido prejudicado por entraves logísticos resultantes dos períodos de suspensão e diminuição das atividades laboratoriais, as populações apresentaram sensibilidade aos compostos de referência dentro das faixas esperadas, portanto, estavam aptas à aplicação em testes de toxicidade.

\subsection{Características dos Contaminante-alvo}

\subsubsection{Afluente e efluente do RALF}

As amostras coletadas representativas de cada fase de operação do reator foram coletadas no dia 19/07/2020 (Fase I), 06/09/2020 (Fase I), 30/10/2020 (Fase II) e 15/02/2021 (Fase III). Em parceria com o LPB, obteve-se acesso aos parâmetros mensurados especificamente para cada amostra, apresentados na Tabela 13, que elucidam de maneira resumida as características da água residuária a jusante da Estação de Tratamento e pós-tratamento biológico no RALF, bem como dados da eficiência do reator, medidas logo após a coleta.

Observa-se em todas as amostras existe uma predominância de DQO solúvel (fácil degradação) sob a DQO particulada (remanescente da DQO bruta- DQO solúvel) em todas as fases. Na Fase III essa diferença é menor, a matéria orgânica particulada chega a representar cerca de 37\% da DQO, no entanto, esta mesma fase apontou a melhor eficiência na remoção de matéria orgânica. Liang et al. (2018) e Raptis, Juraske e Hellweg (2014) encontraram correlação positiva entre demanda química de oxigênio (bruta) e aumento da toxicidade, para as espécies Pseudokirchneriella subcapitata e Ceriodaphnia dubia, respectivamente. Já Sponza e Demirden (2010) encontraram correlação significativa entre DQO oriunda de matéria orgânica lentamente degradável e produtos microbianos inertes, enquanto a correlação entre DQO proveniente de compostos inertes não foi significativa.

Os valores de $\mathrm{pH}$, próximos à neutralidade, não apresentam em si risco para a sobrevivência dos organismos. A respeito da temperatura, antes da inserção de organismos no meio de teste as amostras ficam alocadas em sala aclimatada na mesma temperatura dos cultivos, por isso, a média temperatura da água foi de $26 \pm 2{ }^{\circ} \mathrm{C}$. Nenhuma alteração substancial foi observada nos valores de alcalinidade, embora a relação entre aumento de toxicidade e variação na alcalinidade já tenha sido reportada na literatura (RIETHMULLER et al., 2008) induzido maior biodisponibilidade de substâncias. Nenhuma correlação na literatura foi encontrada entre ácidos voláteis e toxicidade à animais aquáticos. Os resultados apresentados nos tópicos subsequentes poderão elucidar o comportamento dos organismos dessa pesquisa em relação aos parâmetros supracitados. 
Tabela 13 - Parâmetros medidos para amostras de afluente e efluente de cada fase

\begin{tabular}{|c|c|c|c|c|c|c|}
\hline Parâmetro & $A f l u F I$ & Eflu $F I$ & $\begin{array}{l}\text { Aflu } \\
\text { FII }\end{array}$ & $\begin{array}{l}\text { Eflu } \\
\text { FII }\end{array}$ & $\begin{array}{l}\text { Aflu } \\
\text { FIII }\end{array}$ & $\begin{array}{l}E f l u \\
F I I I\end{array}$ \\
\hline Temeratura $\left({ }^{\circ} \mathrm{C}\right)$ & 30 & 34 & 32 & 35 & 28 & 36 \\
\hline $\mathrm{pH}$ & 7,42 & 7,71 & 7,23 & 7,46 & 7,40 & 7,45 \\
\hline $\begin{array}{l}\text { Alcalinidade total (mg } \\
\mathrm{CaCO} 3 / \mathrm{L})\end{array}$ & 281,7 & 276,2 & 308,5 & 246,4 & 213,4 & 267,7 \\
\hline $\begin{array}{l}\text { Ácidos voláteis Totais } \\
(\mathrm{mgHAc} / \mathrm{L})\end{array}$ & 66,1 & 109,9 & 123,0 & 131,9 & 88,1 & 135,7 \\
\hline DQO bruta $(\mathrm{mg} / \mathrm{L})$ & $348 \pm 10$ & $218 \pm 8,5$ & $\begin{array}{l}351,3 \\
\pm 11\end{array}$ & $\begin{array}{l}125,3 \\
\pm 5,3\end{array}$ & $\begin{array}{l}533,3 \\
\pm 16\end{array}$ & $\begin{array}{l}222,3 \\
\pm 6,5\end{array}$ \\
\hline DQO solúvel $(\mathrm{mg} / \mathrm{L})$ & $336 \pm 22$ & $174 \pm 15$ & $\begin{array}{l}355,3 \\
\pm 10\end{array}$ & $194 \pm 3,5$ & $\begin{array}{l}333,3 \\
\pm 15\end{array}$ & $116 \pm 12$ \\
\hline $\begin{array}{l}\text { Eficiência remoção de } \\
\text { Matéria orgânica bruta } \\
(\%)\end{array}$ & - & 37,4 & - & 35,7 & - & 58,3 \\
\hline $\begin{array}{l}\text { Eficiência remoção de } \\
\text { Matéria orgânica solúvel } \\
(\%)\end{array}$ & - & 48,2 & - & 45,4 & - & 65,1 \\
\hline
\end{tabular}

Sendo: $\mathrm{AFLU}=$ afluente, $\mathrm{EFLU}=$ efluente e DQO = Demanda química de oxigênio.

Fonte: Própria do autor (2021)

Os parâmetros medidos no início dos testes de toxicidade, para cada fase, são apresentados de maneira resumida na Tabela 14, com discretizarão detalhada sobre medidas em cada fração e ao final do teste podem ser acessadas no Apêndice A, Apêndice B e Apêndice C.

Os parâmetros apresentados na Tabela 14 não fazem distinção entre afluente e eluente, no entanto, já elucidam as diferentes condições experimentais em que os organismos foram submetidos, as informações mais detalhadas serão apresentadas ao longo da discussão específica para cada organismo. Os valores de pH também estão dentro da faixa estabelecidos para os cultivos dos organismos e indicados em suas metodologias (FONSECA, 1997; OECD, 2011; CORBI et al., 2015; ABNT 2017; CASTRO et al., 2020), por isso, se analisados isoladamente, não causam a toxicidade da amostra. Por outro lado, os valores de oxigênio dissolvido e condutividade elétrica estão fora do faixa sugerida para a manutenção dos cultivos e ótimo desenvolvimento das espécies. Essas alterações observadas são proporcionais ao aumento da fração de afluente ou efluente da amostra e provavelmente estão relacionadas à presença de íons de cloreto (SOUSA et al., 2014) e à demanda química de oxigênio remanescente na amostra. 
Tabela 14 - Parâmetros medidos ao início dos bioensaios para cada fase de operação do reator

\begin{tabular}{lllll}
\hline $\begin{array}{l}\text { Organismo- } \\
\text { teste }\end{array}$ & Parâmetro & Fase I & Fase II & Fase III \\
\hline $\begin{array}{l}\text { Organismos } \\
\text { bentônicos }\end{array}$ & C.E. $(\mu \mathrm{S} / \mathrm{cm})$ & $97,9-807$ & $98,3-877$ & $96-820$ \\
& pH & $6,93-7,82$ & $6,62-7,43$ & $7,41-7,91$ \\
& O.D. $(\mathrm{mg} / \mathrm{L})$ & $5,2-0,9$ & $1,7-2,3$ & $*$ \\
\hline $\begin{array}{l}\text { Ceriodaphnia } \\
\text { silvestrii }\end{array}$ & C.E. $(\mu \mathrm{S} / \mathrm{cm})$ & $212-807$ & $242-500$ & $*$ \\
& pH & $6,41-7,85$ & $6,77-7,09$ & $7,56-7,66$ \\
& O.D. $(\mathrm{mg} / \mathrm{L})$ & $3,5-4,8$ & $2,9-4,5$ & $*$ \\
\hline $\begin{array}{l}\text { Chironomus } \\
\text { sancticaroli }\end{array}$ & C.E. $(\mu \mathrm{S} / \mathrm{cm})$ & $54,1-177,5$ & - & - \\
(crônico) & & & & - \\
& pH & $6,19-6,98$ & - & - \\
\hline
\end{tabular}

Sendo: C.E. $=$ Condutividade elétrica, O.D. $=$ Oxigênio dissolvido, $(*)=$ Indisponibilidade do equipamento e $(-)=$ Teste não executado

Fonte: Própria do autor (2021)

\subsubsection{Diclofenaco}

Os parâmetros analisados a priori dos testes foram coletados e compilados no Apêndice E e estão apresentados de maneira resumida na Tabela 15.

Tabela 15 - Faixa de valores dos parâmetros medidos para as concentrações de diclofenaco

\begin{tabular}{llll}
\hline & $\begin{array}{l}\text { Condutividade } \\
\text { elétrica } \\
(\mu \boldsymbol{S} / \mathbf{c m})\end{array}$ & $\boldsymbol{p H}$ & $\begin{array}{l}\text { Oxigênio dis- } \\
\text { solvido }(\mathbf{m g} / \mathbf{L})\end{array}$ \\
\hline Organismos bentônicos & $45,7-85,5$ & $5,98-7,83$ & $3,8-4,5$ \\
\hline Ceriodaphnia silvestrii & $150,9-157,4$ & $7,11-7,34$ & $3,9-4,2$ \\
\hline C. sancticaroli (crônico) & $46,6-49,4$ & $6,09-7,03$ & $3,9-4,3$ \\
\hline
\end{tabular}

Fonte: Própria do autor (2021)

As concentrações de Diclofenaco na amostra não causaram variações bruscas nos parâmetros físico-químicos do meio-teste analisados. As respostas ecotoxicológicas observadas para esse teste tem, portanto, maior probabilidade de ser decorrente da interação ou ingestão do fármaco pelos organismos. 


\subsection{Teste de toxicidade aguda das amostras do RALF}

Embora os organismos sejam submetidos às mesmas proporções de afluente e efluente do RALF, para a comparação entre fases de operação do reator, as diferenças podem ser melhor compreendidas quando avaliadas por espécie isoladamente, para posterior comparação interespecífica, conforme subdivisão dos tópicos subsequentes.

\subsubsection{Allonais inaequalis}

Os resultados de cada fase foram alocados paralelamente à cada fração para a observação mais clara da progressão da toxicidade, em amostras de afluente e efluente (Figura 20). Os efeitos tóxicos da contaminação por água residuária para o macroinvertebrado Allonais inaequalis foram observados a partir de tratamentos de $6 \%$ para afluente e $12 \%$ para efluente, com sobrevivência expressivamente afetada da população submetida a teste, conforme observado na Figura 20 (a,b).

Figura 20 - Resultado do teste toxicidade aguda utilizando A. inaequalis para a) o afluente ao reator e b) o efluente ao reator

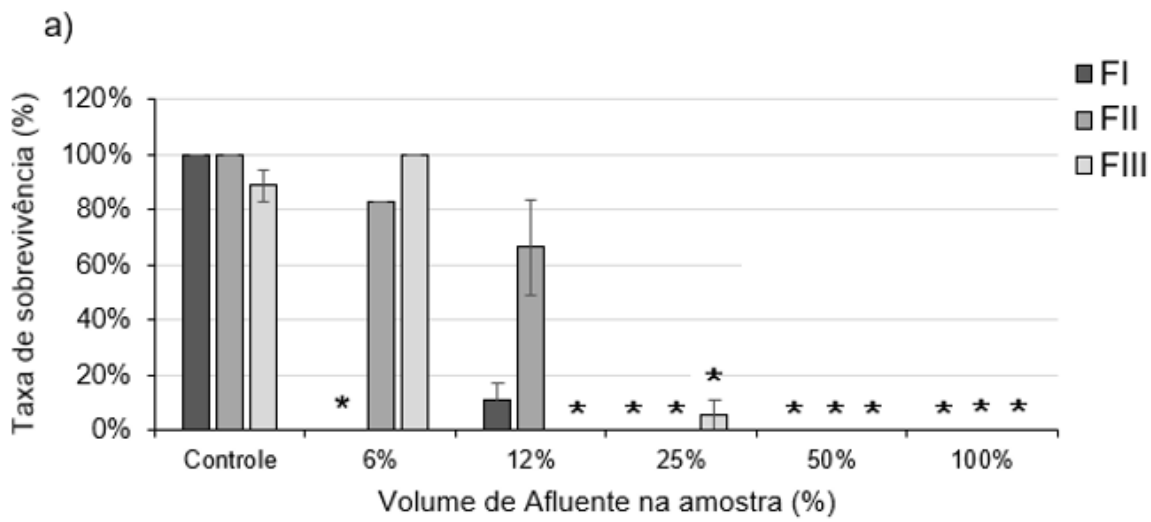

b)

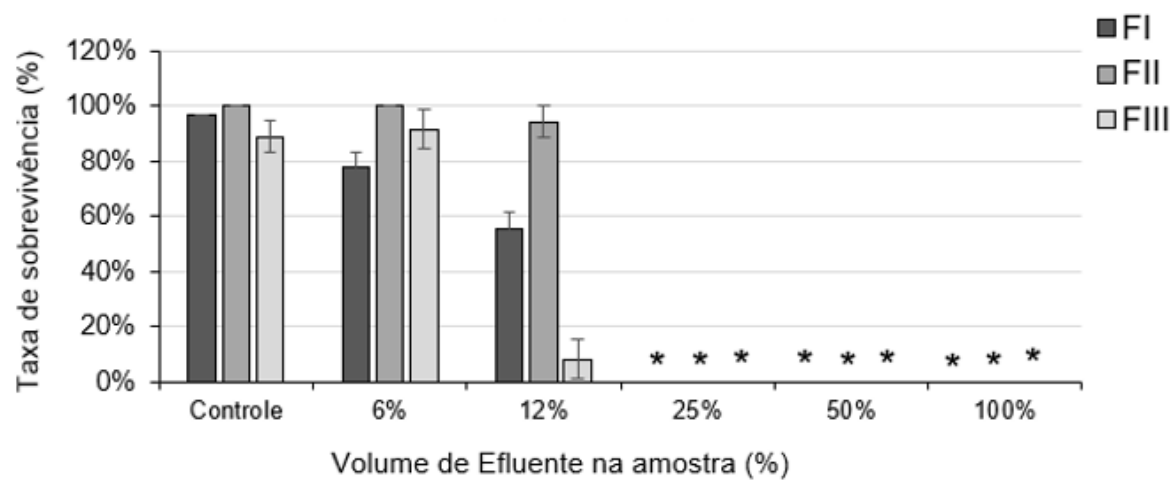

(*) Estatisticamente diferente do controle

Fonte: Própria do autor (2021) 
Através da representação gráfica acima (Figura 20) observam-se maiores taxas de sobrevivência tanto no afluente quanto no efluente na Fase II ( TDH $=12 \mathrm{~h}+$ Nitrato), enquanto a Fase I (TDH $=18 \mathrm{~h}+$ Nitrato) mostrou a maior diferença entre afluente e efluente. A taxa de sobrevivência na Fase III (TDH $=18 \mathrm{~h}$ - Nitrato) não demonstrou expressivas diferenças entre afluente e efluente ao reator, quando se compara a mesma fração dos dois tratamento. Os resultados estatísticos, realizados pelo teste de KruskalWallis e seguido do post-hoc de Dunn, confirmam que a Fase I apresentou diferença do afluente com o controle em diluições menores (6\%), enquanto a mesma diferença estatística para diluições do efluente foi observada em todas as fases (25\%), sendo assim, esta fase foi a que mais reduziu a diferença de toxicidade do efluente em relação ao controle.

Nota-se uma interrupção na diminuição gradativa de sobrevivência em dois gradientes de fração do afluente. Na FI a fração de $6 \%$ apresentou $0 \%$ de taxa de sobrevivência enquanto a fração $12 \%$ apresentou um aumento dessa taxa, com média de 11\%. Da mesma forma, na FIII a fração $12 \%$ apresentou $0 \%$ de taxa de sobrevivência e a fraçãox $25 \%$ apresentou $6 \%$ de sobrevivência. Esses resultados podem ser explicados por um comportamento observado durante o processo de retirada do teste, quando A. inaequalis fez migração para a região superficial da amostra, conforme pode ser observado na Figura 21 (a,b).

Figura 21 - Registro do comportamento de proteção apresentado por Allonais inaequalis em exposição a amostras do RALF. a) Aderência próxima ao espelho d'água e b) aderência acima do nível da água

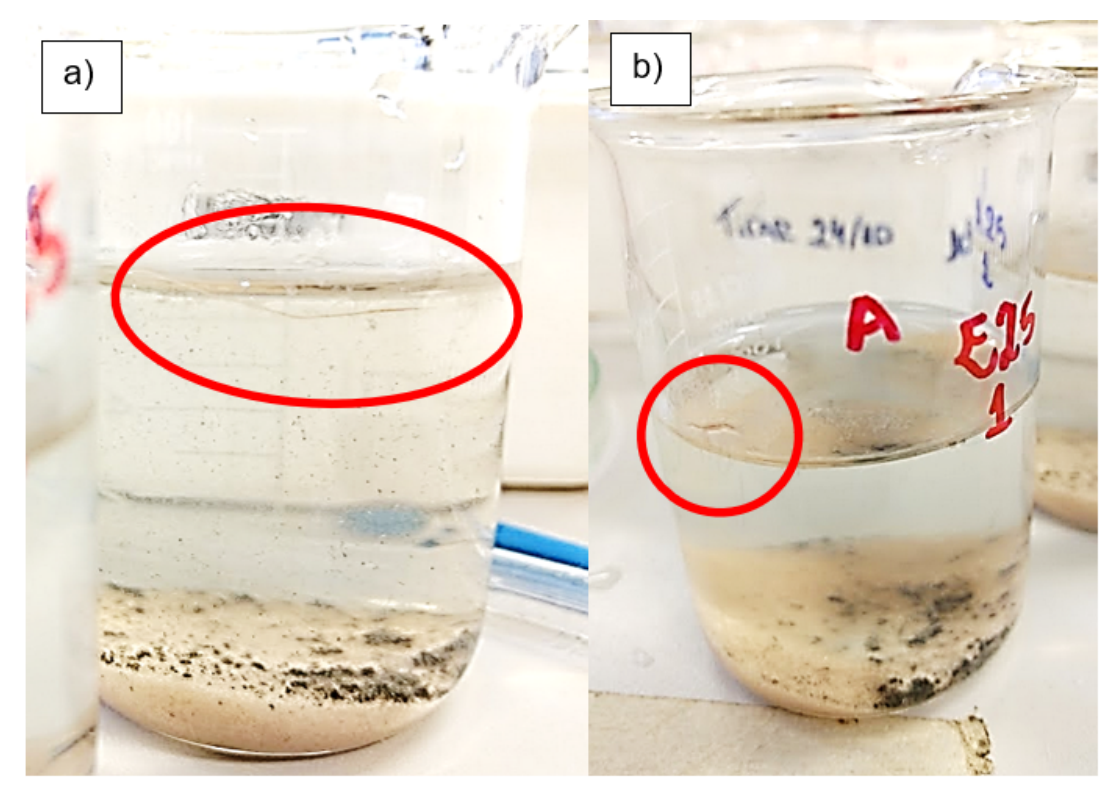

Fonte: Própria do autor (2021)

Em todas as réplicas em que se observou maior sobrevivência em uma fração mais elevada (menos diluída) que na fração antecedente (mais diluída) os organismos estavam 
alocados na camada superior da amostra. Os Oligochaeta, embora alguns possam ser encontrados em natação livre, são uma subclasse de animais predominantemente encontrados aderidos a plantas ou superfícies de sedimento, onde constroem tubos (TIMM; MARTIN, 2015). Mudanças no comportamento dos organismos quando expostos a contaminantes são comumente identificados na ecotoxicologia (GERHARDT, 2007).

Em relação aos Oligochaeta, a migração para a superfície aquática pode ter relação com os maiores níveis de oxigênio dissolvido mais abundantes nas camadas superiores, que são atrativos para a sobrevivência desses organismos (BEHREND et al., 2009). Apesar da qualidade da água ser mais decisiva para a abundância de espécies bentônicas, em alguns casos, que as características do sedimento (DALU et al., 2017), a porcentagem de amostra visível decantada nas réplicas pode indicar um maior consumo de oxigênio naquela região, ou ainda a presença de um agente tóxico associado ao material particupado, observados na Figura 21. Essa proporção de sólidos, aliada ao decaimento progressivo do oxigênio dissolvido (Tabela 16 e Apêndice A), pode ter induzido a espécie a buscar habitats mais favoráveis ao seu desenvolvimento nas superfícies da coluna d'água.

As faixas dos parâmetros físico-químicos iniciais coletados estão expostos na Tabela 16, são apresentadas de forma gradativa das menores frações (6\%) para as maiores (100\%), nas fases I, II e III para os organismos bentônicos (A. inaequalis, P. longiseta e C. sancticroli).

Tabela 16 - Faixa de valores dos parâmetros medidos para os bioensaios utilizando os organismos bentônicos em amostras do RALF

\begin{tabular}{lllll}
\hline & Parâmetros & Afluente & Efluente & Controle \\
\hline \multirow{2}{*}{ Fase I } & C.E $(\mu \mathrm{S} / \mathrm{cm})$ & $97,9-785$ & $99,7-807$ & $49,2-53,1$ \\
& pH & $7,82-7,22$ & $6,74-7,22$ & $7,95-8,25$ \\
& O.D. $(\mathrm{mg} / \mathrm{L})$ & $5,2-1,2$ & $5-0,9$ & $5,7-5,8$ \\
\hline \multirow{2}{*}{ Fase II } & C.E $(\mu \mathrm{S} / \mathrm{cm})$ & $98,3-877$ & $99,0-873$ & $44,4-46,4$ \\
& pH & $7,00-6,72$ & $6,67-7,01$ & $6,79-7,02$ \\
& O.D. $(\mathrm{mg} / \mathrm{L})$ & $2,3-1,5$ & $3,1-1,7$ & $5,6-5,8$ \\
\hline \multirow{2}{*}{ Fase III } & C.E $(\mu \mathrm{S} / \mathrm{cm})$ & $103-820$ & $53-763$ & $53-54$ \\
& pH & $7,91-7,41$ & $7,78-7,54$ & $8,0-8,53$ \\
& O.D. $(\mathrm{mg} / \mathrm{L})$ & $*$ & $*$ & $*$ \\
\hline
\end{tabular}

Sendo: C.E.= Condutividade elétrica, O.D.= Oxigênio dissolvido e $(*)=$ Indisponibilidade do equipamento

Fonte: Própria do autor (2021)

As diferenças entre afluente e efluente do reator, para os parâmetros aferidos, não foram expressivas, podendo-se considerar uma estabilidade nas entre as características de ambos e entre fases. Já em relação ao controle, existe uma variação considerável princi- 
palmente para os dados obtidos de condutividade elétrica, que pode exercer influência na pressão osmótica do meio (SMAGIN et al., 2018), influenciando positiva ou negativamente a toxicidade da amostra. Ressalta-se que essas inferências só podem ser confirmadas através de um teste de identificação da toxicidade (TIE).

Os valores das concentrações de efeito letal a 50\% dos indivíduos submetidos a teste $\left(\mathrm{CL}_{50}\right)$ de cada fase, bem como o a diferença de toxidade entre afluente e efluente (RT), estão expressos na Tabela 17.

Tabela 17 - Valores dos $\mathrm{CL}_{50}$ para $A$. inaequalis submetido a amostras do RALF e os valores de Remoção de Toxicidade (RT) dado em pontos percentuais (pp)

\begin{tabular}{llll}
\hline & Afluente & Efluente & RT \\
\hline Fase I & $0,0 \%$ & $13,0 \%$ & $13,00 \mathrm{pp}$ \\
\hline Fase II & $13,5 \%$ & $14,6 \%$ & $1,10 \mathrm{pp}$ \\
\hline Fase III & $6,9 \%$ & $8,9 \%$ & $2,03 \mathrm{pp}$ \\
\hline
\end{tabular}

Fonte: Própria do autor (2021)

Através da Tabela 17, ratifica-se o observado anteriormente, que apesar do afluente da Fase I $(\mathrm{TDH}=18 \mathrm{~h}+$ Nitrato $)$ ter sido o mais tóxico para $A$. inaequalis, esta foi a fase em que o reator proporcionou a maior redução de toxicidade (13 pp) quando comparado à Fase II $(\mathrm{TDH}=18 \mathrm{~h}+$ Nitrato $)$ e III $(\mathrm{TDH}=18 \mathrm{~h}-$ Nitrato $)$. Esses resultados sugerem que o tempo de detenção hidráulico é mais determinante na sobrevivência da população de $A$. inaequalis que a adesão de nitrato, sinalizando a maior eficiência em neutralização de agentes tóxicos presentes em águas residuárias para TDHs superiores.

\subsubsection{Pristina longiseta}

Analogamente à apresentação gráfica de $A$. inaequalis, as respostas ecotoxicológicas de cada fase foram apresentadas paralelamente à cada fração, em amostras de afluente e efluente (Figura 22). Durante a realização dos testes para a Fase III o invertebrado Pristina longiseta estava indisponível para teste, por isso os dados não foram obtidos. Os efeitos tóxicos de mortalidade expressiva para a exposição a esgoto sanitário, para esse Oligochaeta, foram observados a partir de frações de $12 \%$ para afluente e $25 \%$ para efluente (Figura 22) (a,b), sendo essa espécie mais resistente à contaminação aquática que A. inaequalis.

Os dados apresentados na (Figura 22) expressam a eficiência do reator na remoção de toxicidade entre afluente e efluente para a Pristina longiseta. As maiores taxas de sobrevivência foram observadas na fase II $(\mathrm{TDH}=12 \mathrm{~h}+$ Nitrato), realçada nos valores obtidos para a fração de $12 \%$ do afluente (94\% de sobrevivência). No entanto, a eficiência 
na remoção de toxicidade foi mais acentuada na Fase I (TDH $=18 \mathrm{~h}+$ Nitrato), quando o afluente demonstrou maior efeito agudo na fração $12 \%$ (17\% de sobrevivência) enquanto no efluente esse efeito já é mitigado (83\% de sobrevivência). Quando submetidos à análise de comparação das medianas (Kruskal-Wallis seguido de post-hoc de Dunn) essas diferenças não se mostraram significativas, tanto a Fase I quanto a II apresentaram as mesmas medianas de sobrevivência quando comparado ao controle sendo o afluente diferente a partir da fração $25 \%$ e o efluente a partir da fração $50 \%$.

Figura 22 - Resultado do teste toxicidade aguda utilizando P. longiseta para a) o afluente ao reator e b) o efluente ao reator

a)

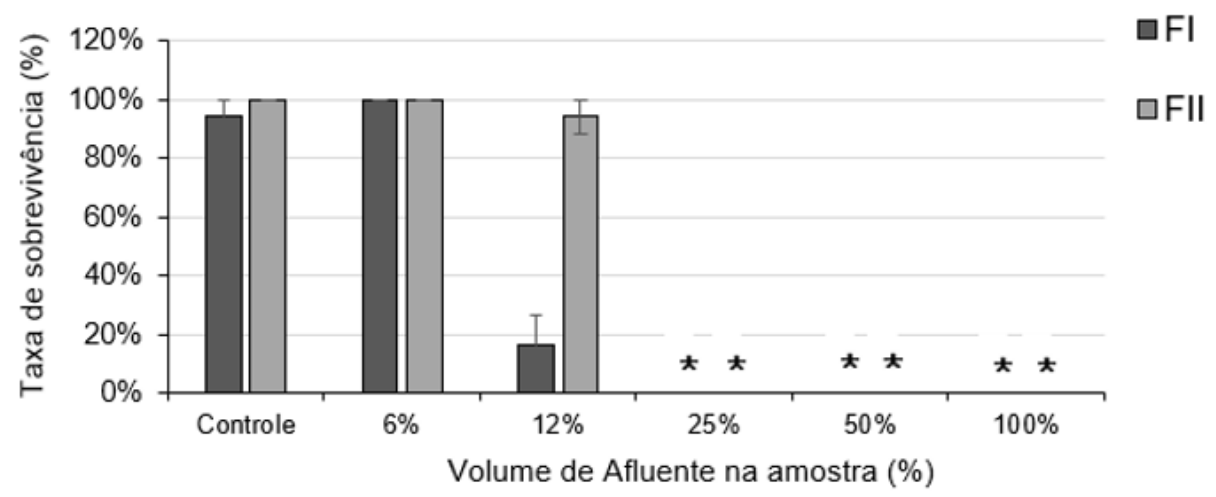

b)

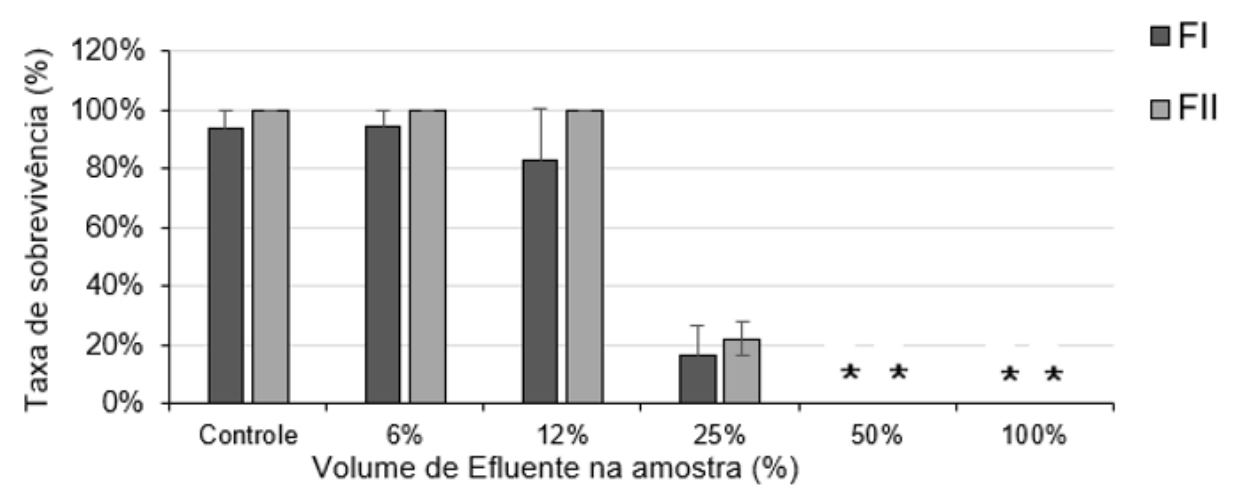

(*) Estatisticamente diferente do controle

Fonte: Própria do autor (2021)

Vale ressaltar que o número de réplicas tem influência direta na robustez e precisão da análise estatística, na perceptiva apenas numérica, esses dados em triplicata não são estatisticamente diferentes, mas, sob a ótica ecológica, um contaminante que causa a mortalidade de $83 \%, 83 \%$ e $72 \%$ da população (afluente $12 \%$ na FI, efluentes $25 \%$ na FI e FII, respectivamente) é sim uma forte fonte de poluição aquática. 
Em comparação a A. inaequalis, Pristina longiseta, apesar de ser da mesma família (Naididae), possui menor habilidade de natação na coluna d'água e por isso é predominantemente encontrada aderida em macrófitas ou em regiões epibentônicas dos sedimentos (SANCHES; GORNI, 2014; CASTRO et al., 2020). Por esta razão, durante a retirada dos testes, nenhum organismo foi encontrado na zona superficial da água, ou nas paredes do béquer, o que resultou em um decaimento progressivo da taxa de sobrevivência sem ocorrência de indivíduos vivos em frações maiores de esgoto.

Os valores dos parâmetros coletados no início do teste foram apresentados no tópico anterior. Os valores das concentrações de efeito letal a 50\% dos indivíduos submetidos a teste $\left(\mathrm{CL}_{50}\right)$ de cada fase, bem como a diferença de toxidade entre afluente e efluente (RT), estão expressos na (Tabela 18).

Tabela 18 - Valores dos $\mathrm{CL}_{50}$ para $P$. longiseta submetido a amostras do RALF e os valores de Remoção de Toxicidade (RT) expressos em pontos percentuais (pp)

\begin{tabular}{llll}
\hline & Afluente & Efluente & $\boldsymbol{R T}$ \\
\hline Fase I & $9,83 \%$ & $18,16 \%$ & $8,33 \mathrm{pp}$ \\
\hline Fase II & $14,59 \%$ & $22,50 \%$ & $7,91 \mathrm{pp}$ \\
\hline
\end{tabular}

Fonte: Própria do autor (2021)

Para Pristina longiseta, a alteração no TDH não implicou em mudanças amplas na eficiência de remoção da toxicidade entre FI e FII, as maiores diferenças são observadas entre afluente e efluente de ambas as fases, o que confirma as repostas estatísticas, ainda que o número amostral não seja abundante. Os valores isolados do $\mathrm{CL}_{50}$ ratificam a maior toxicidade para as duas amostras (efluente e afluente) da Fase I, mas com uma discreta melhora na remoção para a fase $\mathrm{I}(\mathrm{TDH}=18 \mathrm{~h}+$ Nitrato $)$ em relação à fase II $(\mathrm{TDH}=$ $12 \mathrm{~h}+$ Nitrato), sendo assim, para esse organismo, a configuração que melhor mitigou os efeitos adversos da contaminação por efluentes sanitários.

\subsubsection{Chironomus sancticaroli}

As respostas deletérias da exposição do inseto Chironomus sancticaroli à efluente e afluente sanitários para as três fases de operação do RALF estão expressas na (Figura 23). Conforme pode ser observado, esse organismo apresentou maior resistência a poluição por esgotos que $A$. inaequalis e $P$. longiseta na maioria dos tratamentos. A partir da fração que continha $25 \%$ da amostra de afluente o organismo apresentou baixa taxa de sobrevivência, e esse patamar no efluente foi observado a partir da fração $50 \%$ do efluente nas Fases I e II e $25 \%$ na FIII (Figura 23a,b). 
Figura 23 - Resultado do teste toxicidade aguda utilizando C. sancticaroli para a) o afluente ao reator e b) o efluente ao reator

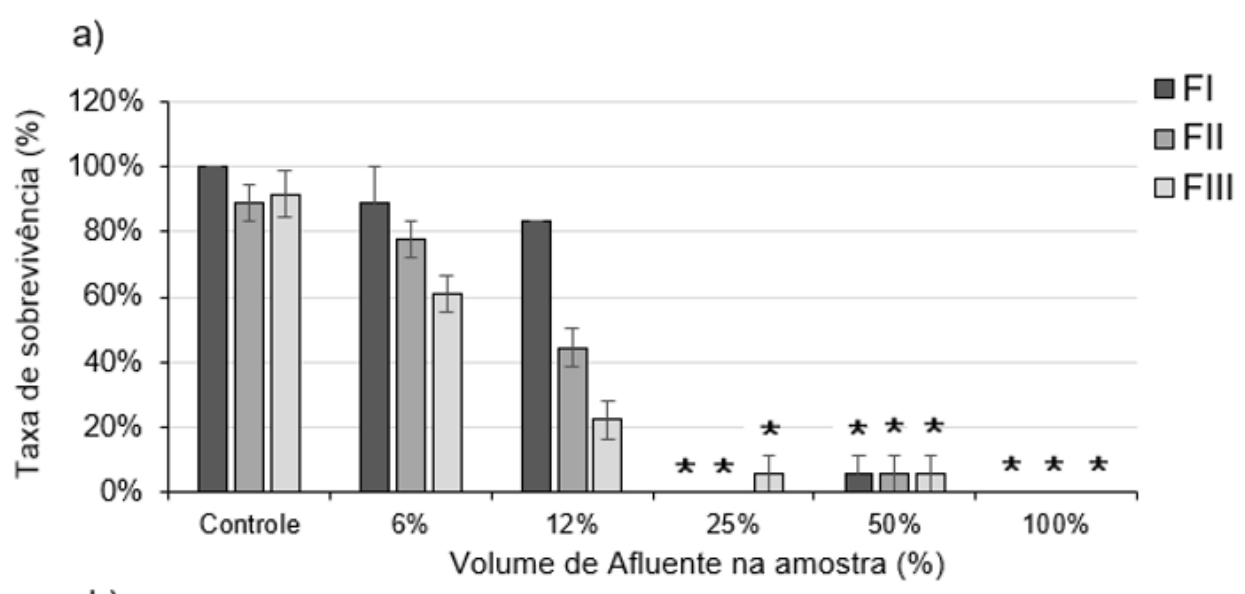

b)

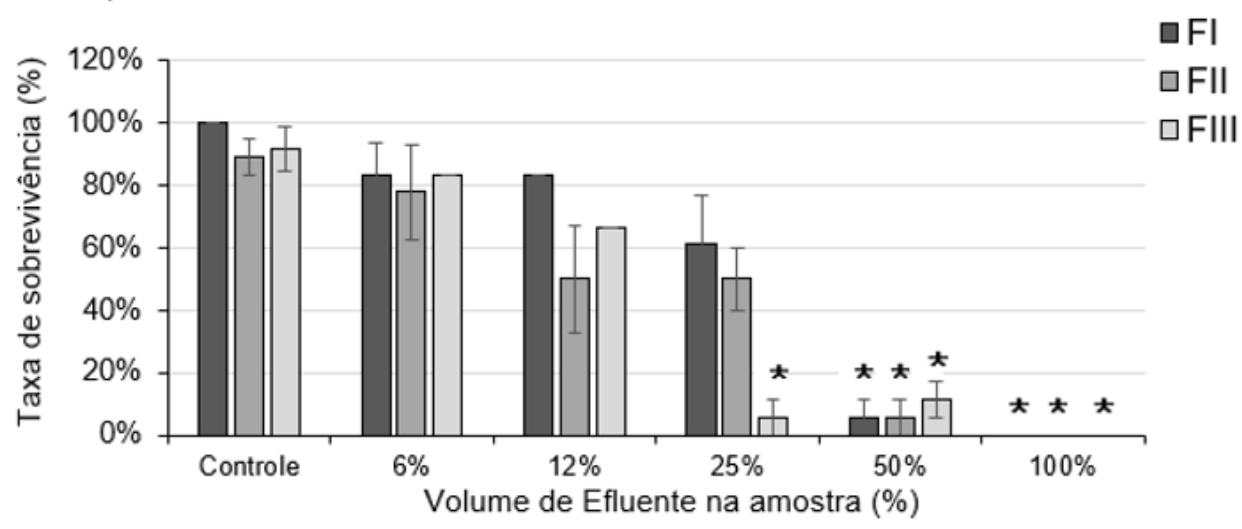

(*) Estatisticamente diferente do controle

Fonte: Própria do autor (2021)

$\mathrm{Na}$ (Figura 23) observa-se também a melhoria na toxidade de afluente para efluente, sinalizando influência do tratamento na toxicidade das amostras para C. sancticaroli, exceto para a Fase III (TDH = 18h sem Nitrato), que não apresentou diferenças significativas entre afluente e efluente, realizado pelo teste de Kruskal-Wallis seguido do post-hoc de Dunn. Diferentemente das outras espécies, a Fase I ( $\mathrm{TDH}=18 \mathrm{~h}+$ Nitrato) foi a menos tóxica para C. sancticaroli, as frações $12 \%$ para os afluentes (Figura 23a) e $25 \%$ dos efluentes (Figura 23b) elucidam bem essas diferenças, apresentando um decaimento gradual da FI à FIII. Apenas através da análise descritiva dos dados não é possível verificar qual fase obteve melhor desempenho na remoção da toxicidade, no entanto, a análise estática não aponta diferença no tratamento para a Fase III, a partir das mesmas frações de afluente e efluente (fração 25\%) existe diferença do controle.

Para Chironomus sancticaroli também existe uma interrupção na progressão da 
toxicidade à medida que a quantidade de efluente ou afluente na amostra aumenta. De maneira análoga a $A$. inaequalis, o inseto $C$. sancticaroli apresentou um comportamento de deslocamento para camadas superficiais da água conforme registrado pela (Figura 24).

Figura 24 - Registro do comportamento de proteção apresentado pelo inseto Chironomus sancticaroli em exposição a amostras do RALF. a) Criação de envoltório na superfície da água e b) criação de envoltório no sedimento

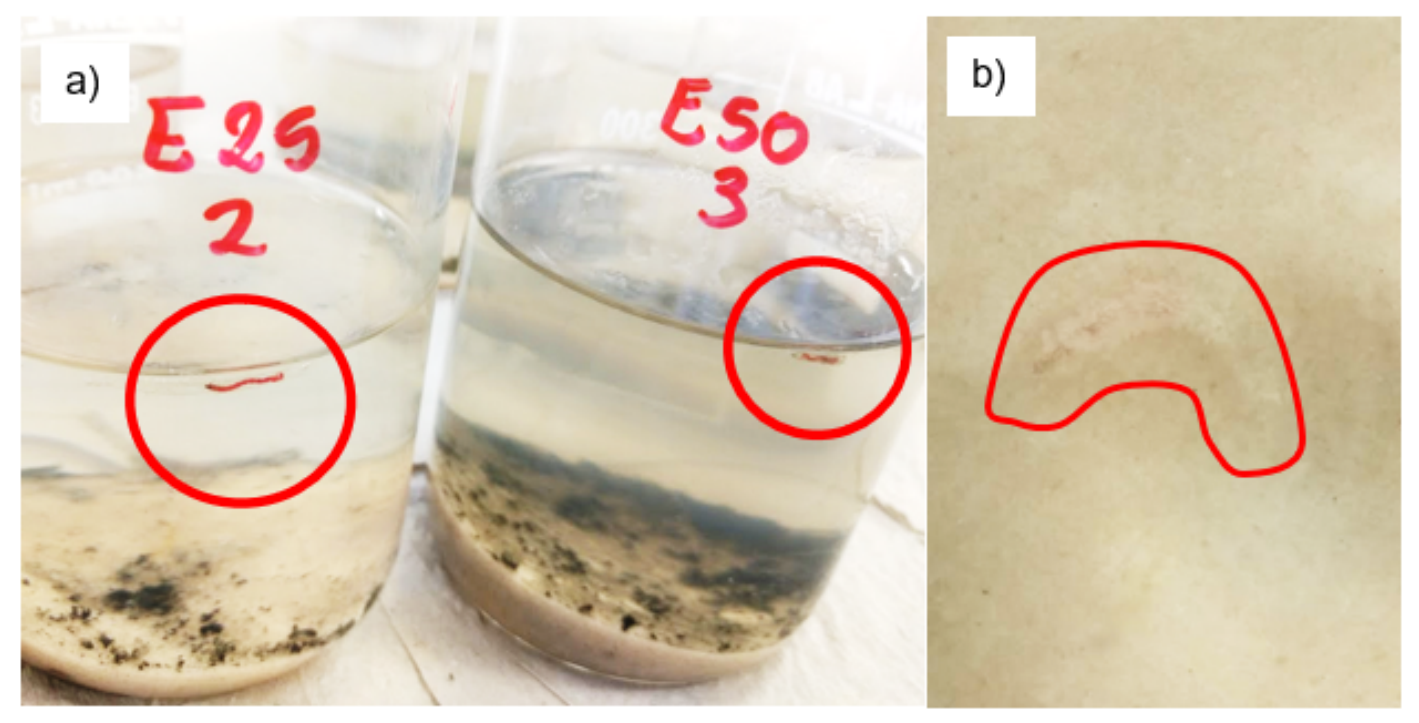

Fonte: Própria do autor (2021)

A criação de tubos gelatinosos é uma característica conhecida da família dos Chironomidae, esses tubos auxiliam na corrente de entrada de oxigênio e alimento, além de proteger essa espécie da predação (ZOU et al., 2019). Esses organismos podem ser uma das únicas espécies bentônicas encontradas nos sedimentos para baixas concentrações de oxigênio dissolvido (ARMITAGE; PINDER; CRANSTON, 2012). Outras espécies da mesma família (e.g. Propsilocerus akamusi) apresentam adaptação metabólica com respiração anaeróbica quando sujeitos a anoxia, estando a sobrevivência desses organismos mais relacionada à disponibilidade de nutrientes e matéria orgânica que à presença de oxigênio (ZOU et al., 2019).

Para Chironomus sancticaroli, melhores condições de sobrevivência foram encontradas na região superficial da amostra (Figura 24a), a criação dos envoltórios permitiu a aderência dos organismos à superfície lateral do béquer. A maior presença de oxigênio na zona superficial da amostra não parece ser um fator determinante na migração desses organismos, como discutido no parágrafo anterior, esses organismos são tolerantes a ausência de oxigênio, o primeiro lote de coleta para criação no LEAA foi tirado de uma lagoa de estabilização de efluentes. Sugere-se que, estes organismos estejam evitando algum outro agente tóxico que esteja presente na parte inferior da amostra (partículas sedimentadas). 
Um outro mecanismo de defesa identificado nesse ensaio foi a criação dos mesmos tubos no sedimento que de certa forma evitaram o contato mais direto com a contaminação (Figura 24b). Nas amostras com maior fração de afluente ou efluente (50\%) em que foram encontrados organismos vivos eles estavam sob as duas condições mencionadas acima.

Os valores das frações de efeito letal a $50 \%$ dos indivíduos submetidos a teste $\left(\mathrm{CL}_{50}\right)$ de cada fase, e as respostas correspondentes à diferença de toxicidade de afluente e efluente (RT) estão expostos na Tabela 19.

Tabela 19 - Valores dos $\mathrm{CL}_{50}$ para C. sancticaroli submetido a amostras do RALF e os valores de Remoção de Toxicidade (RT) dado em pontos percentuais ( $\mathrm{pp}$ )

\begin{tabular}{llll}
\hline & Afluente & Efluente & RT \\
\hline Fase I & $13,72 \%$ & $30,25 \%$ & $16,53 \mathrm{pp}$ \\
\hline Fase II & $12,17 \%$ & $31,63 \%$ & $19,46 \mathrm{pp}$ \\
\hline Fase III & $2,83 \%$ & $13,47 \%$ & $10,64 \mathrm{pp}$ \\
\hline
\end{tabular}

Fonte: Própria do autor (2021)

Os valos de $\mathrm{CL}_{50}$ realçam a diferença da Fase III para as demais fases, confirmando as repostas estatísticas. As diferenças entre Fase I (TDH $=18 \mathrm{~h}+$ Nitrato) e Fase II (TDH $=12 \mathrm{~h}+$ Nitrato) foram irrisórias, a diferença no tempo de detenção hidráulico não afetou significativamente a sobrevivência de $C$. sancticaroli. Com relação à presença ou ausência de Nitrato, a literatura registrou uma baixa correlação entre níveis de nitrato e nitrogênio na água e abundância de larvas de Chironomidae no sedimento em amostras ambientais (AL-SHAMI et al., 2006), o que mais uma vez indica uma outra fonte de toxicidade. Como já discutido no tópico de caraterização das amostras, a Fase III apresentou a maiores valores de DQO particulada em relação às outras fases, a matéria orgânica geradoras de DQO particulada tende a alcançar o inferior da mostra devido a maior densidade, podendo estar associada a outros compostos e ocasionar o aumento da toxicidade tanto do afluente quanto do efluente.

\subsubsection{Ceriodaphnia silvestrii}

As respostas de toxicidade aguda de Ceriodaphnia silvestrii foram representativas da toxicidade para os organismos de coluna d'água. Vale ressaltar que os testes de toxicidade da Fase I e II foram realizados com amostras congeladas de afluente e efluente do RALF, segundo a metodologia permitida pela ABNT NBR 15469 (ABNT, 2007), devido a indisponibilidade do organismo no período de teste ou entraves logísticos com a montagem de todos os testes no mesmo dia. As análises com a Fase III foram montadas em paralelo aos testes utilizando os outros organismos e com amostra fresca, coletada a 
menos de 48h em conformidade com o Manual de Avaliação de Efluentes da CETESB (BERTOLETTI, 2008). Os resultados obtidos para os ensaios com a Ceriodaphnia silvestrii são expressas na Figura 25.

Figura 25 - Resultado do teste toxicidade aguda utilizando C. silvestrii para a) o afluente ao reator e b) o efluente ao reator

a)

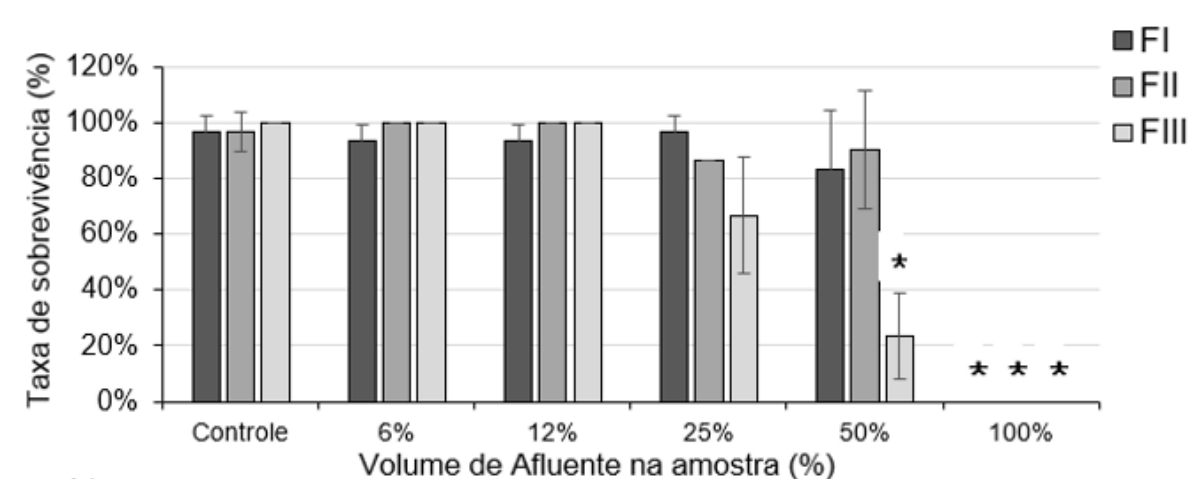

b)

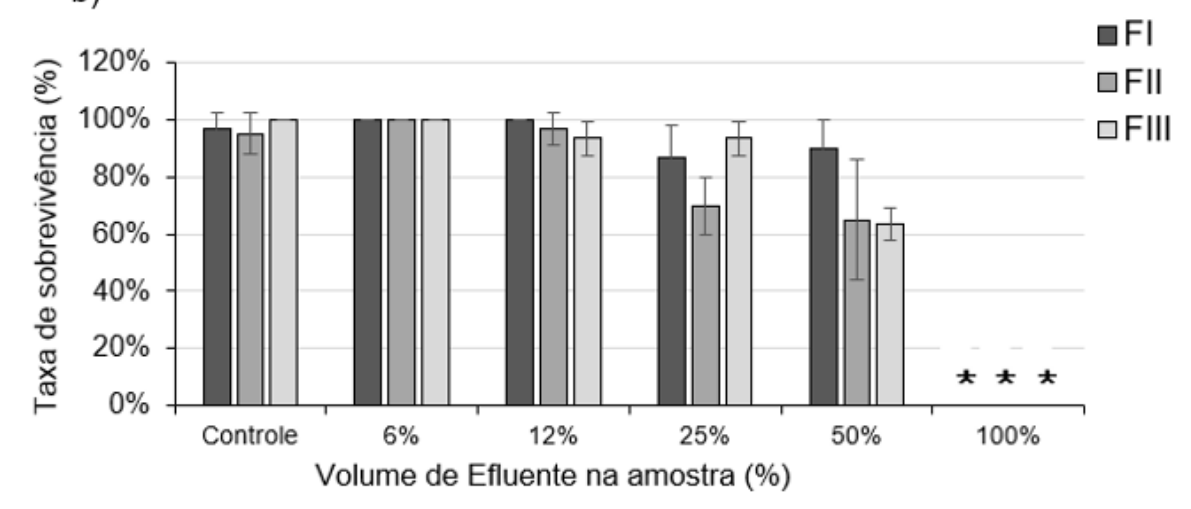

(*) Estatisticamente diferente do controle

Fonte: Própria do autor (2021)

O microcrustáceo Ceriodaphnia silvestrii apresentou boa tolerância à contaminação por efluentes, mesmo na amostra utilizando efluente fresco, sua sensibilidade foi menor que a dos demais organismos avaliados nessa pesquisa. As menores taxas de sobrevivência só são evidentes a partir das frações de 50\% pra os afluentes (Figura 25a) e 100\% para os efluentes (Figura 25b).

Para Ceriodaphnia silvestrii, a presença ou ausência de um tratamento biológico de efluente não influi na taxa de sobrevivência dessa espécie para as Fases I e II, segundo a avaliação estatística (teste de Kruskal-Wallis seguido do post-hoc de Dunn). Observa-se ainda, que na fração $25 \%$ de efluente e afluente para a F I e II ocorre uma diferença negativa entre o afluente e o efluente, a taxa de sobrevivência cai de $97 \%$ para $87 \%$ na FI 
e de $80 \%$ para $70 \%$ na FII, respectivamente. Para a fração $25 \%$ e para a estatística não houve influência de configurações de tratamento para a toxicidade do esgoto doméstico. Somente na FIII existe uma diferença significativa em relação ao controle entre o afluente $50 \%$ e o efluente $50 \%$, onde o primeiro presentou $23 \%$ de sobrevivência (Figura 25a) e o segundo $63 \%$.

As faixas dos parâmetros físico-químicos iniciais coletados e expostas na Tabela 20, são apresentadas de forma gradativa das menores frações para as maiores nas fases I, II e III para Ceriodaphnia silvestrii.

Tabela 20 - Faixa de valores dos parâmetros medidos para os bioensaios utilizando Ceriodaphnia silvestrii em amostras do RALF

\begin{tabular}{lllll}
\hline & Parâmetros & Afluente & Efluente & Controle \\
\hline \multirow{2}{*}{ Fase I } & C.E $(\mu \mathrm{S} / \mathrm{cm})$ & $212-422$ & $212-431$ & - \\
& $\mathrm{pH}$ & $7,12-7,40$ & $7,06-7,70$ & $7,15-7,28$ \\
& O.D. $(\mathrm{mg} / \mathrm{L})$ & $4,7-3,0$ & $4,2-3,5$ & $4,0-3,8$ \\
\hline \multirow{2}{*}{ Fase II } & C.E $(\mu \mathrm{S} / \mathrm{cm})$ & --513 & --499 & - \\
& pH & $6,83-6,90$ & $7,06-6,83$ & $7,51-7,74$ \\
& O.D. $(\mathrm{mg} / \mathrm{L})$ & $4,2-2,8$ & $3,9-2,9$ & $4,3-4,5$ \\
\hline \multirow{2}{*}{ Fase III } & C.E $(\mu \mathrm{S} / \mathrm{cm})$ & $*$ & $*$ & $*$ \\
& pH & $*$ & $*$ & $*$ \\
& O.D. $(\mathrm{mg} / \mathrm{L})$ & $*$ & $*$ & $*$ \\
\hline
\end{tabular}

Sendo: C.E.= Condutividade elétrica, O.D.= Oxigênio dissolvido, $\left({ }^{*}\right)=$ Indisponibilidade do equipamento e $(-)=$ fora do limite de detecção do aparelho.

Fonte: Própria do autor (2021)

A água reconstituída para C. silvestrii contém alta concentração de sais (ver seção 4.1), por este motivo os valores de condutividade elétrica dão acima do $1000 \mu \mathrm{S} / \mathrm{cm}$ (limite de detecção do aparelho). Os valores de oxigênio dissolvido para as Fases I e II estão relativamente semelhantes aos valores do controle, isso pode ter relação com o congelamento e descongelamento da amostra que em alguns casos aceleram a hidrólise de matéria orgânica (YANG et al., 2015) e a própria expansão do líquido pode incorporar ar a amostras biológicas (AUTHELIN et al., 2020). Todos esses fatores podem ter alterado a toxicidade do líquido, embora a maior tolerância desse organismo para amostra fresca também tenha sido identificada.

As concentrações de efeito de imobilização a $50 \%$ dos indivíduos $\left(\mathrm{CE}_{50}\right)$ e suas respectivas fases e configurações, pré ou pós tratamento, estão expostos na Tabela 21. 
Tabela 21 - Valores dos $\mathrm{CE}_{50}$ para $C$. silvestrii submetida a amostras do RALF e os valores de Remoção de Toxicidade (RT) dado em pontos percentuais (pp)

\begin{tabular}{llll}
\hline & Afluente & Efluente & $\boldsymbol{R T}$ \\
\hline Fase I & $58,39 \%$ & $61,62 \%$ & $3,23 \mathrm{pp}$ \\
\hline Fase II & $62,34 \%$ & $64,89 \%$ & $2,55 \mathrm{pp}$ \\
\hline Fase III & $32,95 \%$ & $55,86 \%$ & $22,91 \mathrm{pp}$ \\
\hline
\end{tabular}

Fonte: Própria do autor (2021)

Como já apontado pela estatística, a Fase III apresentou a maior taxa de redução de toxicidade com diferença entre $\mathrm{CE}_{50}$ de afluente e efluente de 22,91 pp, seguido de 3,23 pp na FI e 2,55 pp na FII. Os dados da Tabela 21 indicam uma ligeira melhora entre afluente e efluente de todas as fases, sendo a Fase III a que demonstrou maior melhoria. Observando os dados de concentração efetiva de imobilização $\left(\mathrm{CE}_{50}\right)$ é possível perceber que a Fase III foi também a mais tóxica para C. silvestrii, com aumento de quase $100 \%$ na letalidade do seu afluente em relação às outras fases, enquanto o efluente, apesar de ter sido o mais tóxico, também apresentou valores próximos aos valores das demais fases. Com essa observação pode-se supor que o congelamento influencia na toxicidade do esgoto, mas não degrada algum agente tóxico que permanece na massa líquida mesmo após o tratamento. A influência no congelamento da amostra, para essa espécie, pode ser dada apenas pela ausência de oxigênio dissolvido, que para os outros organismos na FI e II apresentavam valores menores. O agente tóxico remanescente pode ter sua origem na parcela inferior da amostra, aonde C. silvestrii não costuma habitar. No entanto, essas afirmações só poderiam ser verificadas e confirmadas por meio de teste de indentificação da toxicidade da amostra (TIE).

\subsubsection{Comparação entre espécies}

O teste de toxicidade aguda utilizando as 4 espécies apresentadas anteriormente indicam que o afluente foi mais tóxico que o efluente na maioria dos resultados, ainda que numa diferença pequena para alguns. Esse é um resultado positivo, uma vez que os subprodutos gerados no tratamento biológico podem aumentar a toxicidade do efluente (FARRÉ et al., 2008). Para a estatística, quando os dados de mortalidade num geral entre fases, sem diferenciação entre frações, são comparados através do teste de Kruskal-Wallis seguido do post-hoc de Dunn, nenhuma fase apresenta diferença estatística da outra para os quatro invertebrados submetidos a teste.

Os Oligochaeta se mostraram os mais sensíveis às amostras tanto de efluente quanto de afluente do reator independente da fase de operação conforme observado nos tópicos anteriores, sendo Allonais inaequalis o mais afetado. A diferença entre eles pode ser 
explicada pelo maior tempo de exposição estabelecida para teste utilizando A. inaequalis (96h) e $P$. longiseta (48h), possibilitando maior tempo de contato com os contaminantes do meio. A resposta desses organismos é importante pois em alguns ecossistemas os Oligochaeta são responsáveis por boa parte da produção secundária (WU et al., 2013) e dentro desde grupo os Naididae já foram identificados como a família mais abundante em rios brasileiros (BEHREND et al., 2009).

Próximo à sensibilidade de $P$. longiseta está a de Chironomus sancticaroli, como terceiro organismo mais sensível para a maioria dos tratamentos. A resposta desse organismo às amostras de afluente e efluente foi surpreendente pois, como já discutido anteriormente, os Chironomidae são normalmente encontrados em ambientes degradados (RAUNIO; PAAVOLA; MUOTKA, 2007), e se desenvolvem bem em meios com abundância de matéria orgânica (WANTZEN et al., 2016), o que é o caso das amostras de esgoto em questão. Molineri et al. (2020) identificaram que nem todos os táxons de Chironomidae são representativos de ambientes degradados, Chironomus sancticaroli, apesar de ter sido coletado em lagoas de estabilização, pode ser um desses táxons com tolerância mediana à poluição aquática.

Oligochaeta e Chironomidae juntos são usualmente os grupos mais utilizados para a determinação de ambientes impactados (CHANG et al., 2014; ROSA et al., 2014). Dalu et al. (2017), investigaram a contribuição da qualidade do sedimento na abundância de macroinvertebrados e constataram maior influência da qualidade da água para espécies bentônicas em detrimento da qualidade do sedimento, em amostras ambientais. No caso da contaminação por efluentes, e nesse caso, exposição única e concentrada, essa constatação pode não se encaixar, uma vez que os efluentes geram contaminação do sedimento, por diversos agente tóxicos como metais, substâncias emergentes entre outros (CZEKALSKI; DÍEZ; BÜRGMANN, 2014; LI et al., 2014; PINTADO-HERRERA et al., 2017; SANTOS et al., 2018). A migração dos organismos A. inaequalis e C. sancticaroli para regiões superficiais da amostra contribuem para essa inferência.

As repostas encontradas com a espécie Ceriodaphnia silvestrii, também evidenciam a predominância de contaminação profundal da amostra em detrimento da contaminação na coluna d'água. As Cladoceras, embora sensíveis a contaminação amoniacal presente no esgoto (NØRGAARD; ROSLEV, 2017), são encontradas em ambientes impactados por efluentes (VARSHNEY et al., 2014; KUMAR; KIRAN, 2016), o que indica uma certa tolerância a poluição a esgotos. Sua principal rota de contato com agentes tóxicos é através do processo de filtração não seletiva do meio aquoso (AGASILD; NÕGES, 2005; SCHERER et al., 2017; HAYASHI-MARTINS et al., 2017), por isso esses organismos estão menos sujeitos às partículas sedimentadas.

Os estudos comparando os efeitos adversos de efluentes em espécies de Cladocera com outras espécies de animais aquáticos são importantes no esclarecimento do papel desse 
grupo como bioindicadores. Nesse contexto, Ceriodaphnia dubia mostrou-se mais sensível a efluentes domésticos que as larvas de Danio rerio (SILVA et al., 2021b), enquanto Villa et al. (2018) constataram que tanto a Cladocera D. magna quando o Chironomidae Diamesa cincerella apresentaram as mesmas respostas quando expostos a efluente doméstico bruto. A avaliação de múltiplas espécies em análises de toxicidade de efluentes tem se mostrado útil no refinamento de soluções de tratamento (KLAMERTH et al., 2010; RIZZO, 2011; MAGDEBURG et al., 2014), e a avaliação da toxicidade de esgotos utilizando as Cladóceras, o grupo de organismos mais utilizados na ecotoxicologia, vem ganhado espaço dentro da engenharia sanitária (DÜPONT; LOBO, 2012; COSTA et al., 2014; MACEDA-VEIGA et al., 2015; SILVA et al., 2021b).

A representação da sensibilidade das espécies testadas pode ser melhor visualizada através da curva de distribuição de sensibilidade das espécies (SSD), apresentada na Figura 26 segundo cada tratamento, utilizando os dados de $\mathrm{CL}_{50}$ ou $\mathrm{CE}_{50}$ obtidos nos ensaios de toxicidade aguda. No eixo vertical está sinalizada a fração da comunidade (representada pelas quatro espécies utilizadas para teste) afetada pelo correspodente valor de concentração letal ou efetiva de cada fração de afluente ou efluente dada no eixo horizontal.

De acordo com as informações observadas na Figura 26, percebe-se que o valor de $\mathrm{CE}_{50}$ que causa perigo de mortalidade à $50 \%$ da comunidade habitante do ambiente impactado (Hazard Concentration - HA50) está entre os valores obtidos utilizando os organismos C. sancticaroli e P. longiseta. Isso significa que, dentro do grupo de organismos analisados, esses dois tem a sensibilidade mais representativa dessa comunidade, indicando que $50 \%$ da fração de comunidade afetada estaria sendo alcançada nas concentrações de efeito letal desses dois organismos.

Apesar do RALF ter conduzido a uma redução da toxicidade entre afluente e efluente para a maioria dos tratamentos, todos os organismos apresentaram $100 \%$ de mortalidade quando submetidos a amostras brutas dos afluentes e efluentes do reator em todas as fases de operação. Essa conclusão indica a necessidade de tratamento subsequentes a essa etapa, principalmente, para a sedimentação de partículas. O que já se é esperado, uma vez que o RALF faz parte do tratamento secundário e sujeito a terceira etapa. 
Figura 26 - Curva de distribuição das espécies expoxtas a a) afluente da FI; b) efluente da FI; c) afluente da FII; d) efluente da FII; e) afluente FIII e f) efluente da FIII.

a)

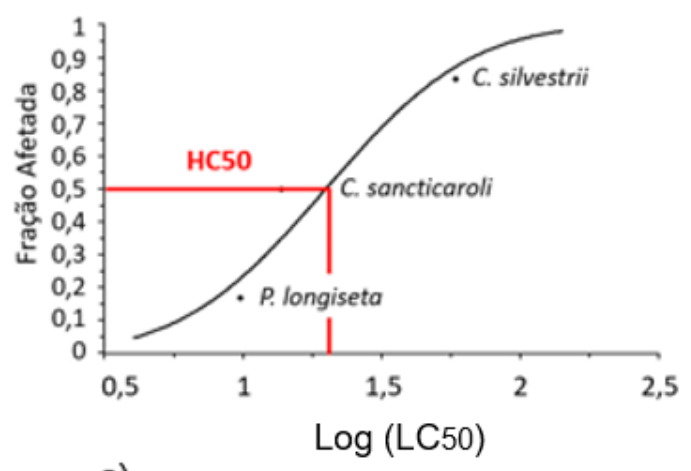

c)

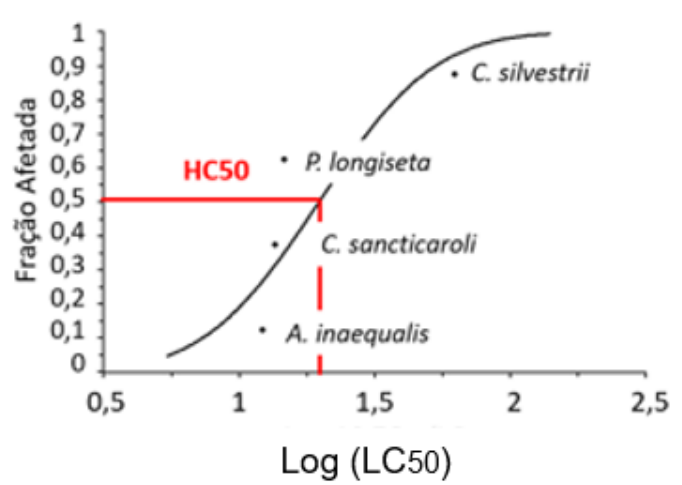

e)

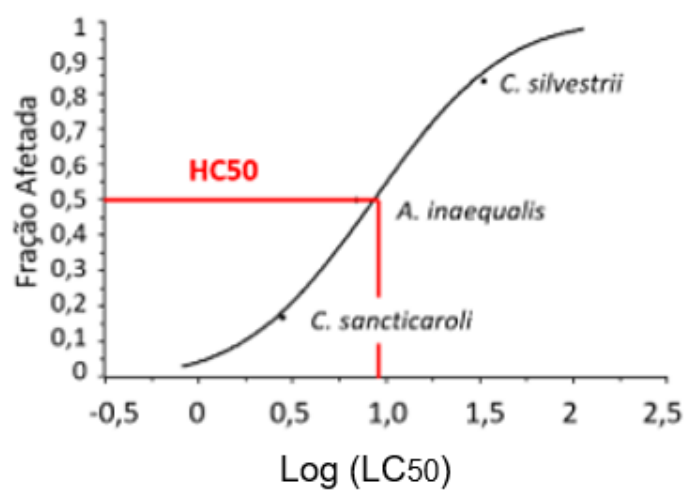

b)
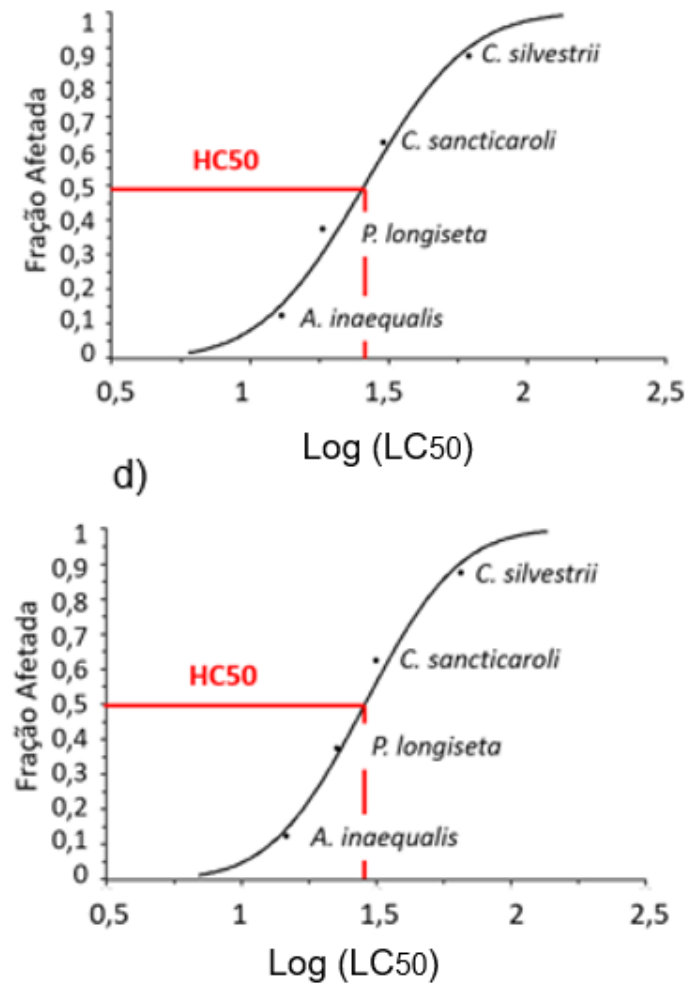

f)

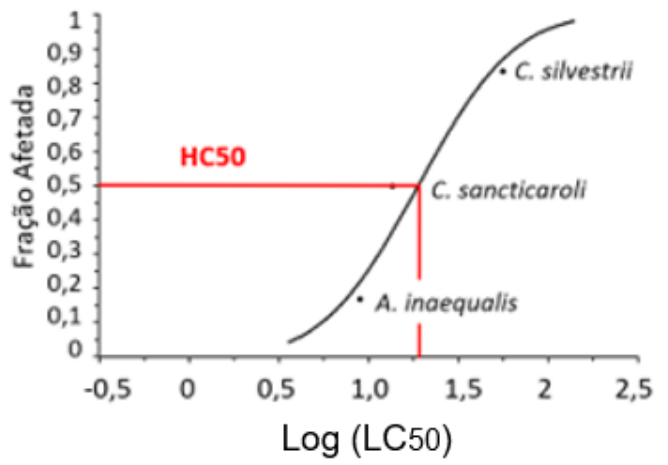

Fonte: Própria do autor (2021)

Quando comparado a dados pesquisados por Issa (2019), avaliando o afluente da ETE em questão e o seu efluente final, após tratamento terciário, o afluente também levou a mortalidade total das espécies D. magna, C. sancticaroli e $I$. inaequalis, enquanto o efluente bruto levou às taxas médias de sobrevivência de 65,55\%,36,11\% e 0\% para as mesmas espécies, respectivamente. Observa-se que nesta pesquisa também prevaleceu a 
maior tolerância a contaminação para os organismos de coluna d'água, sendo Chironomus sancticaroli um representante do impacto causado a essa comunidade especificamente. Para que o RALF se apresente como uma alternativa mais eficiente que a tecnologia em funcionamento atualmente na ETE, sob a ótica da remoção da toxicidade, o tratamento terciário precisaria fazer a toxicidade para o efluente bruto passar de $0 \%$ a pelo menos $37 \%$, utilizando-se os dados de C. sancticaroli na fase que mais removeu toxicidade (FII).

De acordo com as diretrizes de toxicidade estabelecidas pela CONAMA 430 (BRASIL, 2011), o padrão de lançamento de efluentes em corpos receptores deve levar em consideração a toxicidade da amostra para dois níveis tróficos. Na Tabela 22 apresenta os valores do $\mathrm{CL}_{50} / 3$, correspondendo à fração limite permitida desse efluente em corpos receptores de Classe 2 e 3 para cada organismo, segundo os valores obtidos utilizando os efluentes das três fases de operação do RALF.

Tabela 22 - Proporção ou fração de efluente permitido em corpos receptores de Águas Doces classes 2 e 3 com base nos ensaios de toxiciade aguda

\begin{tabular}{llll}
\hline & Fase I & Fase II & Fase III \\
\hline C. sancticaroli & $10 \%$ & $11 \%$ & $4 \%$ \\
\hline A. inaequalis & $4 \%$ & $5 \%$ & $3 \%$ \\
\hline P. longiseta & $6 \%$ & $8 \%$ & - \\
\hline C. silvestrii & $21 \%$ & $22 \%$ & $19 \%$ \\
\hline
\end{tabular}

Fonte: Própria do autor (2021)

Tomando-se o organismo A. inaequalis como um desses representantes, observa-se que somente os efluentes da Fase I e II estão aptos a serem lançados em corpos receptores de Classe 2 e 3 com vazão 25x maior que a vazão da estação, enquanto na Fase III essa proporção precisaria ser de 33x. Se o organismo selecionado fosse Ceriodaphnia silvestrii, para a mesma classe de corpo receptor esse efluente poderia ser lançado em proporções semelhantes entre as fases em córregos 5x maiores que a vazão de lançamento. Tomando-se o organismo mais representativo dentre os avaliados em todas as fases, C. sancticaroli, essa descarga poderia ser feita em rios com vazão em torno de 10x maior que a vazão da Estação nas Fases I e II e 25x na Fase III. Adotando-se um organismo representativo da comunidade é possível fazer essa avaliação sem superestimação de resultados ou subestimação.

Vale ressaltar, que para a estação de tratamento de esgoto em questão, não existe exigência de toxicidade máxima, uma vez que a Classe do rio que recebe esses efluentes é a Classe 5, portanto, no parâmetro "toxicidade" esse efluente pode ser lançado em corpo receptor em qualquer uma das condições analisadas nesta pesquisa, quando respeitados às exigências mínimas de $\mathrm{pH}$, temperatura, demanda bioquímica de oxigênio, materiais 
sedimentáveis, e outros parâmetros físico-químicos preconizados pela CONAMA 430 (BRASIL, 2011).

\subsection{Teste de toxicidade crônica das amostras do RALF}

Sabendo-se da repercussão da sobrevivência dos invertebrados aquáticos a efluente e afluente do RALF, em ensaios de curta duração, é importante compreender os efeitos crônicos da exposição da biota aquática a essas amostras. Para tanto, o inseto C. sancticaroli, foi escolhido como representante devido às respostas encontradas com os testes anteriores. A Fase I (fase intermediária em remoção de toxicidade) foi utilizada para demonstrar esses efeitos em exposição de longa duração, em diluições ainda maiores. A coleta foi realizada no dia 08 de setembro de 2020, seus parâmetros físico-químicos já foram apresentados na subseção 5.2.1.

\subsubsection{Sobrevivência}

Embora a sobrevivência não seja uma resposta-alvo nos ensaios crônicos os resultados obtidos através dessa variável demonstraram melhores taxas de sobrevivência para o efluente sob o afluente principalmente nas frações superiores (6\% e 12\%), conforme apresentado na Figura 27.

Figura 27 - Porcentagem de sobrevivência de larvas do inseto $C$. sancticroli submetidos a amostras do RALF após 10 dias de exposição

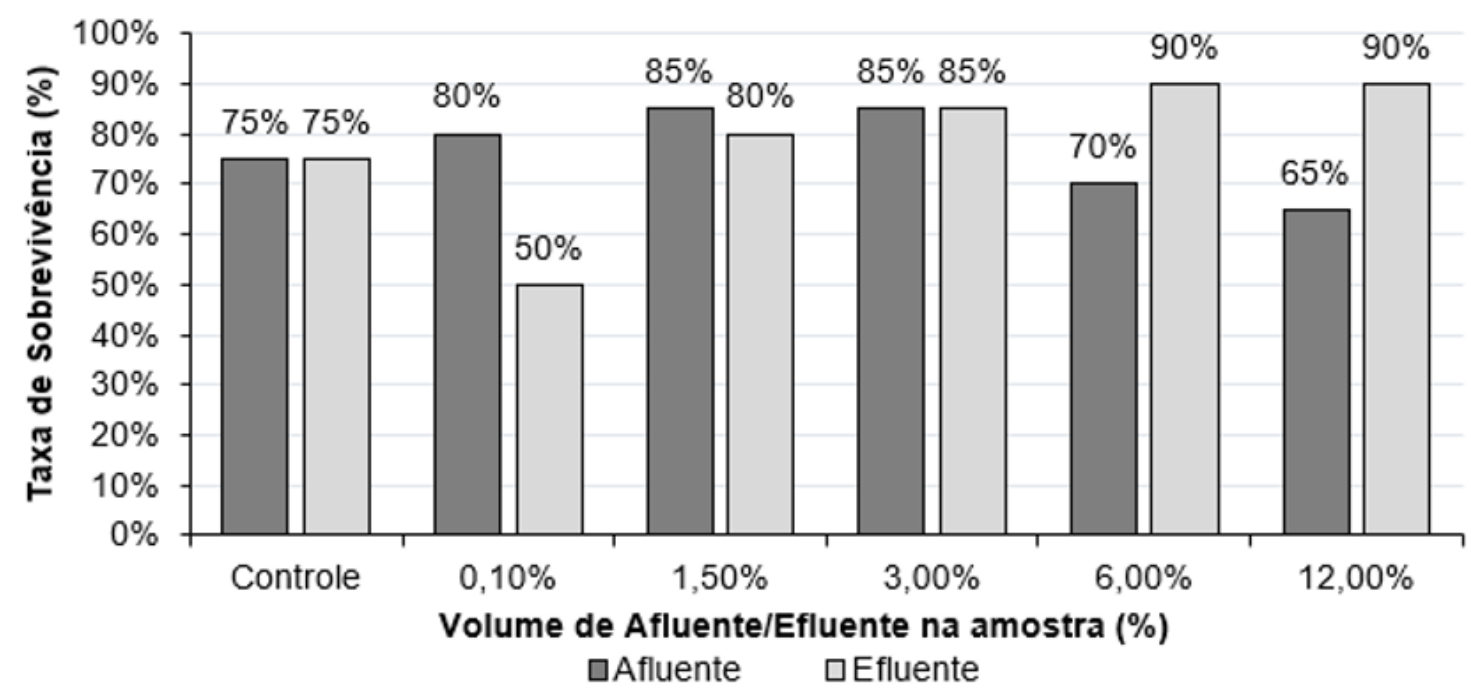

Fonte: Própria do autor (2021)

Como o ensaio não possui número de réplicas extras, não foi possível determinar 
se as diferenças entre controle e os demais tratamentos foram significativas. No entanto, percebe-se que o afluente contendo $12 \%$ de amostra foi levemente mais tóxico comparandose ao controle enquanto nessa mesma fração o efluente favoreceu a sobrevivência do inseto na sua fase larval. Nogueira et al. (2015) sujeitaram larvas de primeiro ínstar de Chironomus riparius sob quatro tipos de efluentes e coletaram resultados de mortalidade chegando até $60 \%$ em efluentes brutos, e com taxa de sobrevivência no controle de $97 \%$. Nesse trabalho as larvas eram alimentadas três vezes por semana com $1 \mathrm{mg}$ de Tetramin ${ }^{\circledR}$, enquanto para os organismos desta pesquisa a alimentação acontecia uma vez por semana como $2,5 \mathrm{mg}$ de Tetramin®. Essa diferença pode ter sido decisiva na longevidade das larvas nesse teste e por essa razão, no efluente com maior disponibilidade de matéria orgânica (12\%), as larvas sobreviveram em maior proporção.

\subsubsection{Comprimento larval}

O comprimento larval de C. sancticaroli foi medido e apresentado na Figura 28 com o desvio-padrão respectivo de cada tratamento e indicação de diferença estatística do controle.

Figura 28 - Comprimento corporal das larvas do inseto C. sancticroli submetidos a amostras do RALF após 10 dias de exposição

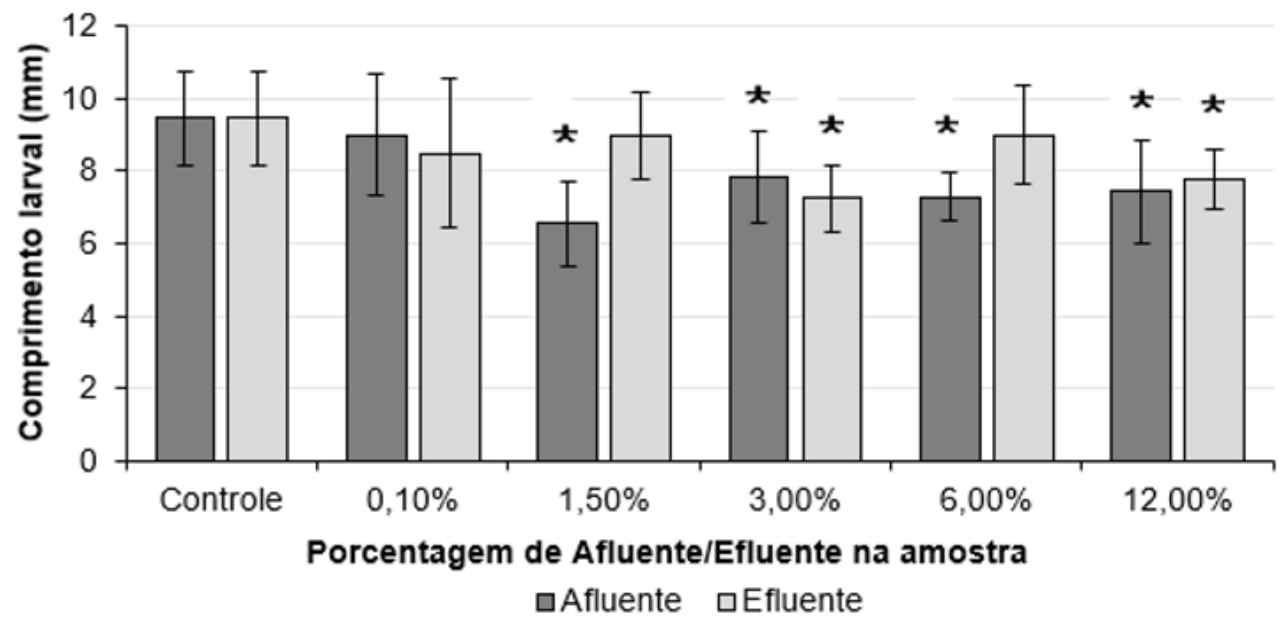

(*) Estatisticamente diferente do controle

Fonte: Própria do autor (2021)

O tamanho normal das larvas de Chironomidae medidas no controle e tomadas como referência ficou em torno de 9mm (Figura 28), esse valor médio está em conformidade com os valores limites descritos por (TRIVINHO-STRIXINO, 1980). Todas as frações de afluente, com a exceção da fração $0,1 \%$ apresentaram diferença estatística do controle. 
As frações do efluente que apresentaram diferença estatística do controle foram somente a $3 \%$ e a $12 \%$. Essa diferença entre afluente efluente sinaliza a eficiência de remoção de compostos tóxicos. Ainda assim, a presença de substâncias inibidoras do crescimento em concentrações baixas das amostras ressalta o potencial tóxico dos esgotos domésticos para a biota aquática, ainda que essa vazão seja diluída na vazão do rio.

Nogueira et al. (2015) também verificaram inibição ao crescimento corporal de Chironomus riparius em amostras de 2 efluentes, um de moinho de azeite e outro de fábrica de celulose, e a indução ao crescimento para a mesma espécie submetida a amostras de drenagem de mineradoras. Ele atribuiu a toxicidade do efluente do moinho do azeite e da fábrica de celulose a interações com outros possíveis compostos tóxicos associados à matéria orgânica. Smeti et al. (2019) também verificaram inibição de crescimento da largura da cápsula cefálica de $C$. riparius à medida que aumentava a poluição por efluente de moinho de azeite. Nanopartículas carbônicas, microplásticos, princípios ativos de repelentes, aumento de temperatura, entre outros, são agentes tóxicos com comprovada ação sobre o comprimento larval de espécies da família Chironomidae (WAISSI-LEINONEN et al., 2015; CAMPOS et al., 2016; WAISSI et al., 2017; STANKOVIĆ et al., 2020; WONGLERSAK et al., 2021), todas essas substâncias podem ser encontradas em amostras de efluentes, bem como tantas outras de efeito desconhecido nesses organismos (AKPOR et al., 2014; MICHAEL-KORDATOU et al., 2015).

Embora os dados de sobrevivência da larva tenham mostrado maiores taxas de sobrevivência nas maiores concentrações de efluente, o crescimento da larva apresentou comportamento contrário. Ou seja, apesar do organismo ter sobrevivido, seu crescimento foi prejudicado, podendo ser ocasionado por competição por alimento ou por ingestão de agentes tóxicos juntamente com a matéria orgânica. Vale ressaltar que a investigação acertada do agente causador de toxicidade nas amostras só pode ser determinada através dos testes de identificação da toxicidade (TIE).

\subsubsection{Deformidades bucais}

Após a medição do comprimento larval, a cápsula cefálica de cada indivíduo foi separada, montada em lâmina e fotografada para a análise deformidade mandibular. Alguns exemplares de cada tratamento do afluente e efluente do RALF podem ser observados na Figura 29 e Figura 30.

Observados os números de dentes, vãos e ausências de dentes os números identificados estão detalhados na Figura 31.

As deformidades identificadas no tratamento controle demonstram baixas alterações em situações de normalidade (13,3\%). As únicas frações que apresentaram taxa de deformidade superior à taxa do controle são as diluições $12 \%$ do Afluente e $6 \%$ e $12 \%$ do Efluente, conforme pode ser observado na última coluna da Figura 31. Esse comportamento vem de 
encontro aos dados obtidos nas análises passadas, quando o afluente favoreceu a toxicidade em mais diluições que o efluente, indicando que algum subproduto do tratamento induz danos morfológicos na estrutura dentária das larvas de Chironomidae.

Figura 29 - Registro da morfologia bucal de exemplares de $C$. sancticaroli de cada tratamento do afluente do RALF
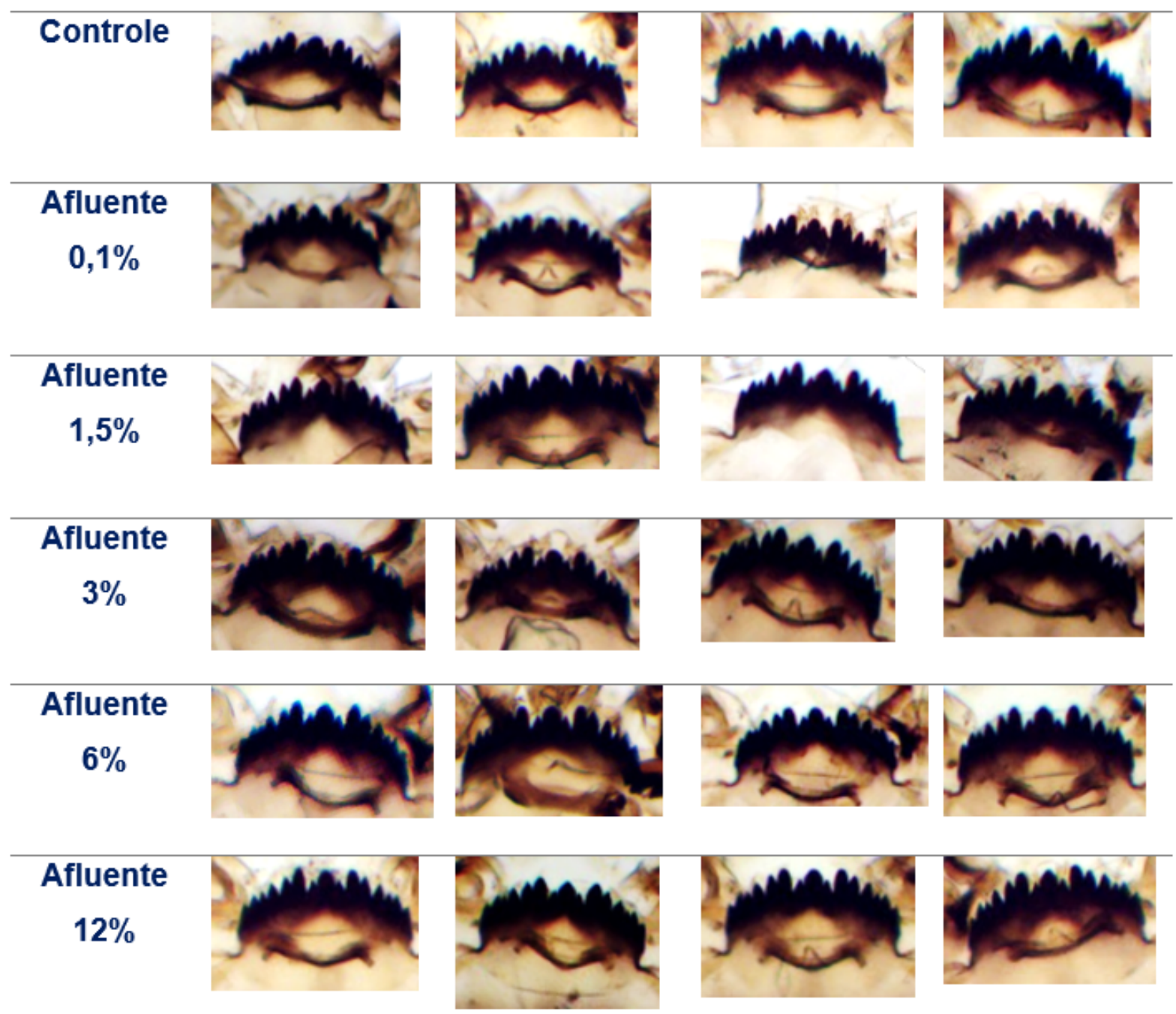

Fonte: Própria do autor (2021) 
Figura 30 - Registro da morfologia bucal de exemplares de $C$. sancticaroli de cada tratamento do efluente do RALF

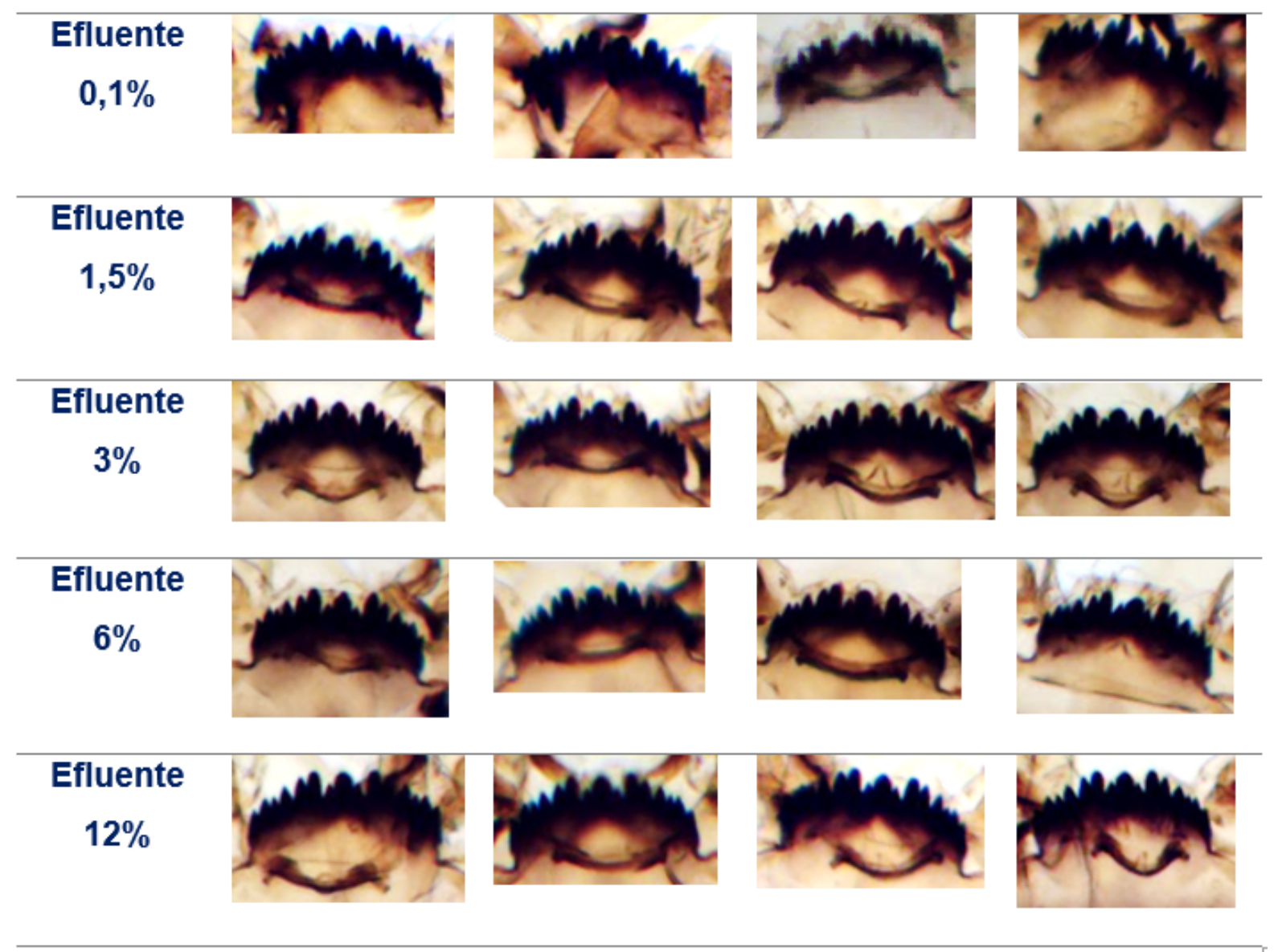

Fonte: Própria do autor (2021)

Algumas substâncias já detectadas em efluentes, como microplásticos, plastificantes, metais pesados, colorantes entre outros, tem comprovada ação na alteração no mentos de Chironomidae (PARK; KWAK, 2008; DELIBERALLI et al., 2018; SAVIĆ-ZDRAVKOVIĆ et al., 2018; STANKOVIĆ et al., 2020), os processos de biodegradação fornecidos pelo RALF podem ter deixado alguma delas persistir na amostra, ou ter ativado de alguma forma alguns compostos. Para as demais frações $(0,1 \%, 1,5 \%, 3 \%$ de efluente e afluente e $6 \%$ do afluente), essas substâncias ou não estavam presentes, ou não estavam presentes em quantidades suficientes para causar dano a Chironomus sancticaroli. 
Figura 31 - Número de deformidades bucais identificadas nas larvas de C. sancticaroli de cada tratamento do efluente do RALF

\begin{tabular}{|c|c|c|c|c|c|c|c|c|c|c|c|c|c|}
\hline \multirow{3}{*}{$\begin{array}{l}\text { Volume de } \\
\text { Esgoto na } \\
\text { amostra } \\
(\%)\end{array}$} & \multirow{3}{*}{$n$} & \multicolumn{10}{|c|}{ Deformidades específicas } & \multirow{2}{*}{\multicolumn{2}{|c|}{$\begin{array}{c}\text { Total de } \\
\text { larvas } \\
\text { deformadas }\end{array}$}} \\
\hline & & \multicolumn{2}{|c|}{$\begin{array}{l}\text { Köehn } \\
\text { vão }\end{array}$} & \multicolumn{2}{|c|}{$\begin{array}{c}\text { Dente } \\
\text { faltando }\end{array}$} & \multicolumn{2}{|c|}{$\begin{array}{c}\text { Dente } \\
\text { sobrando }\end{array}$} & \multicolumn{2}{|c|}{$\begin{array}{c}\text { Sem } \\
\text { dentes }\end{array}$} & \multicolumn{2}{|c|}{$\begin{array}{c}\text { Dente } \\
\text { desgastado }\end{array}$} & & \\
\hline & & $n$ & $\%$ & $n$ & $\%$ & $n$ & $\%$ & $n$ & $\%$ & $n$ & $\%$ & $n$ & $\%$ \\
\hline Controle & 15 & 0 & 0 & 0 & 0 & 1 & 6,6 & 0 & 0 & 1 & 6,6 & 2 & 13,3 \\
\hline A 0,1 & 16 & 0 & 0 & 1 & 6,25 & 0 & 0 & 0 & 0 & 0 & 0 & 1 & 6,25 \\
\hline A 1,5 & 16 & 0 & 0 & 1 & 6,25 & 0 & 0 & 0 & 0 & 0 & 0 & 1 & 6,25 \\
\hline A 3 & 16 & 0 & 0 & 0 & 0 & 0 & 0 & 0 & 0 & 1 & 6,25 & 1 & 6,25 \\
\hline A 6 & 14 & 0 & 0 & 1 & 7,14 & 0 & 0 & 0 & 0 & 0 & 0 & 1 & 7,14 \\
\hline A 12 & 13 & 1 & 7,7 & 1 & 7,7 & 0 & 0 & 0 & 0 & 1 & 7,7 & 2 & 15,4 \\
\hline E 0,1 & 8 & 1 & 12,5 & 1 & 12,5 & 0 & 0 & 0 & 0 & 0 & 0 & 1 & 12,5 \\
\hline E 1,5 & 16 & 0 & 0 & 1 & 6,25 & 0 & 0 & 0 & 0 & 0 & 0 & 1 & 6,25 \\
\hline E 3 & 16 & 0 & 0 & 1 & 6,26 & 0 & 0 & 0 & 0 & 0 & 0 & 1 & 6,25 \\
\hline E 6 & 15 & 0 & 0 & 3 & 20 & 0 & 0 & 0 & 0 & 0 & 0 & 3 & 20 \\
\hline E 12 & 16 & 0 & 0 & 2 & 12,5 & 1 & 6,25 & 0 & 0 & 1 & 6,25 & 4 & 25 \\
\hline
\end{tabular}

Onde $\mathrm{A}=$ Afluente e $\mathrm{E}=$ Efluente

Fonte: Própria do autor (2021)

As imagens de algumas deformidades encontradas nesse teste são ilustradas na Figura 32. Embora não seja possível afirmar quais substâncias específicas ocasionaram dano a morfologia dentária de Chironomus sancticaroli, os dados de comprimento larval e deformidade no mentos nos permitem concluir que o Efluente do RALF só poderia ser despejado em corpos receptores de Classe 1 e 2 se esse corpo receptor tivesse vazão 66 vezes maior que a vazão de lançamento da ETE. 
Figura 32 - Deformidades identificadas em larvas submetidas a afluente e efluente do RALF. a) vão de Köehn; b) dentes faltando; c) dentes sobrando e d) dente desgastado
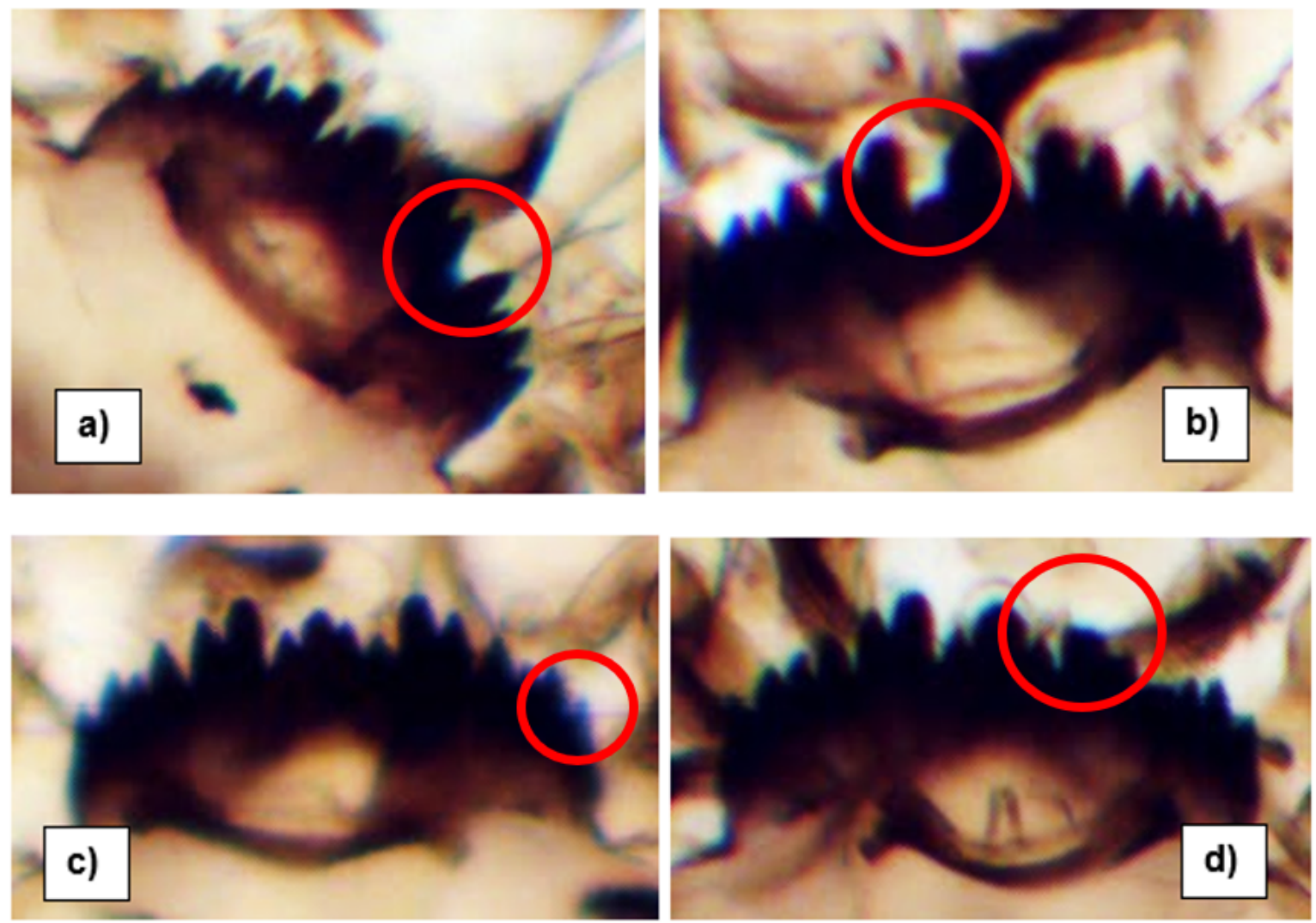

Fonte: Própria do autor (2021)

\subsection{Toxicidade Aguda do Diclofenaco}

Do mesmo modo que a análise da toxicidade aguda realizada para as amostras do RALF, a avaliação dos efeitos adversos do diclofenaco à biota aquática foram avaliados separadamente por grupos, os dois Oligochaeta Allonais inaequalis e Pristina longiseta, a Cladócera Ceriodaphnia silvestrii e o inseto aquático Chironomus sancticaroli. O detalhamento dos parâmetros físico-químicos coletados estão expressos no Apêndice E

\subsubsection{Toxicidade para o Allonais inaequalis e a Pristina longiseta}

Os gradientes de concentração obtidos nos ensaios preliminares para $A$. inaequalis e $P$. longiseta foram semelhantes, em comparação às outras espécies testadas nessa pesquisa, demonstrando uma reação similar desse grupo à presença do DCF. Por esse motivo, eles serão analisados no mesmo tópico, como representantes do grupo dos Oligocheta.

A sensibilidade de Pristina longiseta ao DCF se mostrou mais acentuada que em 
relação a Allonais inaequalis, principalmente quando se leva em consideração que essa espécie foi exposta a um tempo de teste inferior (48h) enquanto A. inaequalis foi submetido a 96h, com efeito sobre a sobrevivência significativamente diferente ao controle observada nas concentrações a partir de $70 \mathrm{mg} / \mathrm{L}$. Para A. inaequalis essa mortalidade acentuada foi observada a partir da concentração $80 \mathrm{mg} / \mathrm{L}$, conforme pode ser observado na expressão gráfica dos resultados na Figura 33.

Figura 33 - Resultado do teste toxicidade aguda do diclofenaco utilizando os organismo a) $P$. longiseta e b) A. inaequalis

a)

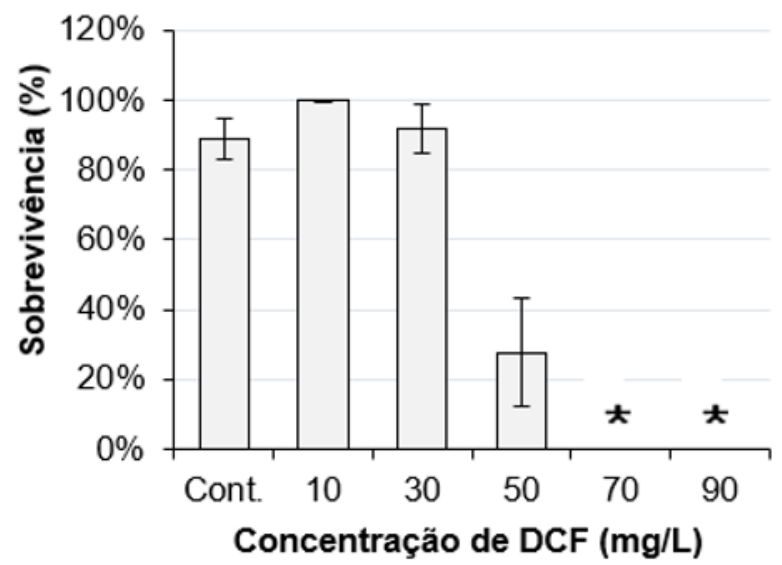

b)

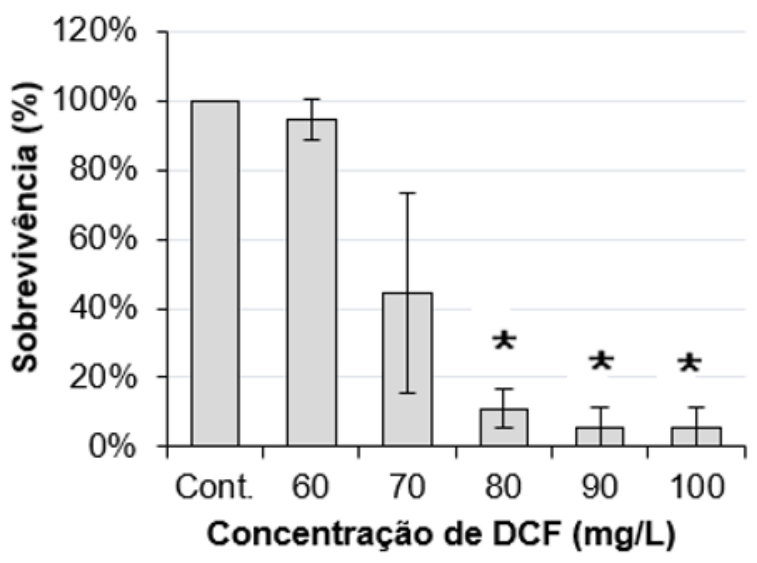

(*) Estatisticamente diferente do controle

Fonte: Própria do autor (2021)

Os dois Oligochaeta foram as espécies menos sensíveis ao DCF apresentando valores de $\mathrm{CL}_{50}$ de $47,49 \mathrm{mg} / \mathrm{L}$ para $P$. longiseta e $68,41 \mathrm{mg} / \mathrm{L}$ para $A$. inaequalis. Pesquisas relatando toxicidade para Oligochaeta aquático são geralmente escassas, sendo as espécies terrestres o representante mais utilizado dessa subclasse em ensaios de toxicidade. Nesse sentido, DCF apresentou toxicidade letal $\left(\mathrm{CL}_{50}\right)$ de $90 \mathrm{mg} / \mathrm{kg}$ para Eisenia fetida (PINO et al., 2015). Esse resultado coloca a sensibilidade dos Oligochaeta aquáticos ao DCF entre a sensibilidade média dos macroinvertebrados de $5,49 \mathrm{mg} / \mathrm{L}$ a $166 \mathrm{mg} / \mathrm{L}$ identificado por Lonappan et al. (2016) e atualizado na Tabela 4.

Com relação à menor sensibilidade dessas espécies com relação às demais estudadas nessa pesquisa, Karlsson (2013) verificou que a adsorção de DCF da água para o sedimento foi a menor quando comparada a outros 8 fármacos e a exposição dessa substância com os organismos se dá pela água presente nos poros do sedimento, por isso é esperado que a 
sensibilidade seja menos observada em organismos em contato com o sedimento, como foi o caso dos dois Oligochaeta nessa pesquisa.

A diferença de toxicidade do DCF para organismos do mesmo grupo e submetidos à condições de teste semelhantes já foram avaliadas em pesquisa científica. Duas diferentes espécies de Oligochaeta terrestres foram analisadas (Lumbricus terrestris e Eisenia fetida) por Carter, Ryan e Boxall (2016) e diferentes concentrações de efeito do DCF foram encontradas para cada uma, apesar de expostas às mesmas condições de teste. Esse resultado se assemelha ao encontrado para $A$. inaequalis e $P$. longiseta nos ensaios de toxicidade aguda do diclofenaco, apesar de submetidos às mesmas condições, com exceção do tempo de exposição e pequena diferença nas concentrações, as repostas entre dois organismos foram diferentes, talvez em um tempo maior de exposição para $P$. longiseta, essa diferença tivesse sido ainda maior.

Os parâmetros coletados no início do teste são apresentados na Tabela 23, com expressões do range de máximos e mínimos, das maiores as menores cocnetrações no tratamento.

Tabela 23 - Faixa de valores dos parâmetros medidos para os bioensaios utilizando os organismos $A$. inaequalis e P. longiseta em exposição ao DCF

\begin{tabular}{llll}
\hline & Parâmetros & Tratamentos & Controle \\
\hline P. longiseta & C.E $(\mu \mathrm{S} / \mathrm{cm})$ & $51,3-69,0$ & $51,4-59,5$ \\
& $\mathrm{pH}$ & $7,83-6,22$ & $8,32-8,02$ \\
& O.D. $(\mathrm{mg} / \mathrm{L})$ & $4,1-3,8$ & $3,9-3,6$ \\
\hline \multirow{2}{*}{ A. inaequalis } & C.E $(\mathrm{\mu S} / \mathrm{cm})$ & $35,7-80,1$ & $49,1-64,3$ \\
& $\mathrm{pH}$ & $7,24-6,82$ & $7,81-8,06$ \\
& O.D. $(\mathrm{mg} / \mathrm{L})$ & $4,5-3,8$ & $3,8-3,9$ \\
\hline
\end{tabular}

Sendo: C.E.= Condutividade elétrica e O.D.= Oxigênio dissolvido

Fonte: Própria do autor (2021)

O Diclofenaco não demonstrou possuir propriedades que afetem o oxigênio dissolvido na amostra logo nos primeiros momentos da mistura, no entanto, à medida que as concentrações aumentavam, foi observado uma diminuição no pH da amostra assim como um aumento, ainda que discreto se comparada à diferença com o esgoto doméstico, na condutividade elétrica.

A relação entre $\mathrm{pH}$ e bioacumulação do diclofenaco por Oligochaeta aquático Lumbriculus variegatus foi analisada por Karlsson (2013), que constatou que a diminuição do $\mathrm{pH}$ favorece o fator de bioconcentração no tecido dos organismos. Como a água controle de $A$. inaequalis e de $P$. longiseta possui $\mathrm{pH}$ um pouco mais alto que a neutralidade, sugerese que por esse motivo os efeitos letais da presença do diclofenaco não tenha sido observado 
em concentrações mais baixas, e por esse motivo esses Oligochaeta são os mais tolerantes, dentro do grupo de animais estudado. O mesmo estudo (KARLSSON, 2013) constatou que Lumbriculus variegatus não metaboliza o diclofenaco, sendo esse composto detectado no tecido do organismo na mesma estrutura química que é encontrado na água. No caso de $A$. inaequalis e de $P$. longiseta, se repetido o mesmo comportamento do Lumbriculus variegatus, sua tolerância pode representar uma maior biodisponibilidade desse fármaco para animais de níveis tróficos superiores por meio de mecanismos de biomagnificação.

\subsubsection{Toxicidade para Ceriodaphnia silvestrii}

Diferentemente do observado com os resultados de toxicidade do RALF, a Cladocera Ceriodaphnia silvestrii apresentou maior sensibilidade que os Oligochaeta, com efeito sobre a sobrevivência desses organismos estatisticamente significante sendo observado em concentrações a partir de 36mg/L (Figura 34) em um tempo de exposição de 48h.

Figura 34 - Resultado do teste toxicidade aguda do diclofenaco utilizando C. silvestrii

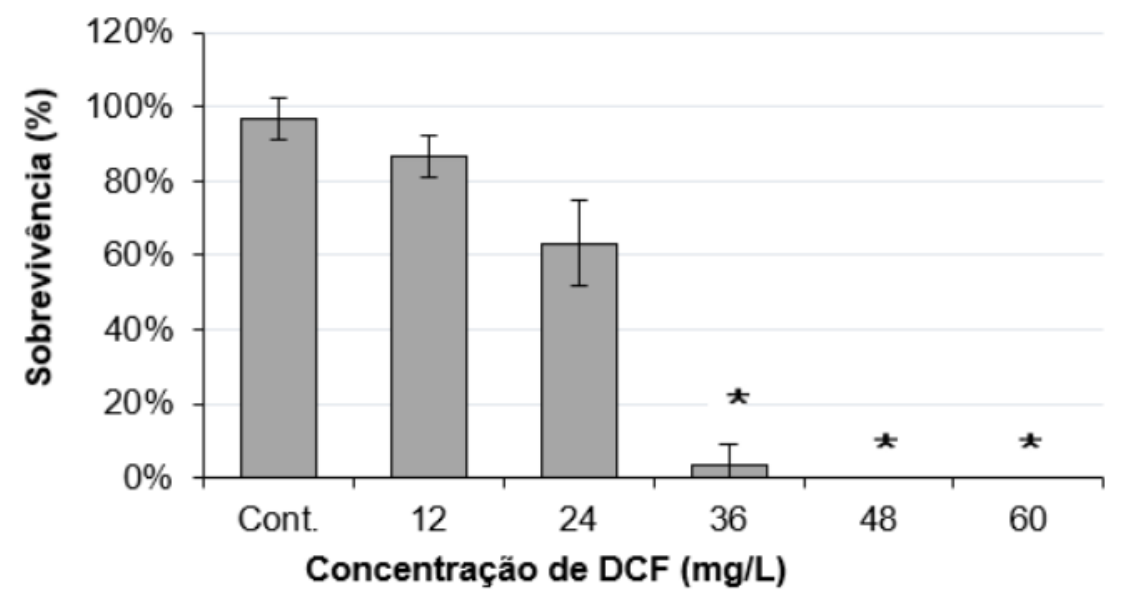

(*) Estatisticamente diferente do controle

Fonte: Própria do autor (2021)

Os resultados obtidos através dos dados de sobrevivência culminaram no valor de 26,43 mg/L para Concentração de Efeito de imobilidade para $50 \%$ da população de $C$. silvestrii submetida a teste. $\mathrm{O}$ valores de $\mathrm{CE}_{50}$ para a imobildade de cladóceras expostos ao DCF é bem avaliado na literatura, os testes realizados com Ceriodaphnia silvestrii foram realizados principalmente a título de comparação com os demais resultados publicados. Nesse sentido, Oliveira et al. (2018) e Caldas et al. (2021), observaram valores próximos para a mesma espécie de $\mathrm{CE}_{50}$ de $37,9 \mathrm{mg} / \mathrm{L}$ e 14,59 mg/L, respectivamente, o que coloca 
os dados obtidos utilizando C. silvestrii dessa pesquisa em conformidade com esses estudos publicados.

$\mathrm{O}$ valor de $\mathrm{CE}_{50}$ encontrado nessa pesquisa, no entanto, se aproximaram mais dos valores encontrados para outras espécies de cladóceras. Para Ceriodaphnia dubia, Ferrari et al. (2003) relatou $\mathrm{CE}_{50}$ de $22,7 \mathrm{mg} / \mathrm{L}$. Para a espécie Daphnia magna os valores de toxicidade aguda do DCF para $50 \%$ da população submetida foi observada nas concentrações 18,1 mg/L (DU et al., 2016) e 39,9 mg/L (HAAP; TRIEBSKORN; KÖHLER, 2008), próximas das concentrações encontradas para C. silvestrii, também. Outros resultados utilizando D. Magna foram realizados, alcançando $\mathrm{CE}_{50}$ de $68 \mathrm{mg} / \mathrm{L}$ (CLEUVERS, 2004), 80,28 mg/L (MINGUEZ et al., 2016) e 96,6 mg/L (GÓMEZ-OLIVÁN et al., 2014). A exposição de DCF para a espécie Daphnia similis também foi avaliada e apresentou $\mathrm{CE}_{50}$ de $46 \mathrm{mg} / \mathrm{L}$ (CASTRO et al., 2014). Dessa forma, sensibilidade dos microcrustáceos ao DCF, com relação à imobilização, se encontra entre 14,59 mg/Le 96 $\mathrm{mg} / \mathrm{L}$.

Os parâmetros coletados no início dos testes estão descritos na Tabela 24, apresentandose a faixa coletada para os gradientes de concentração testados (tratamentos) e controle.

Tabela 24 - Faixa de valores dos parâmetros medidos para os bioensaios utilizando a C. silvestrii em exposição ao $\mathrm{DCF}$

\begin{tabular}{llll}
\hline & Parâmetros & Tratamentos & Controle \\
\hline C. silvestrii & C.E $(\mu \mathrm{S} / \mathrm{cm})$ & $150,9-157,4$ & $164,3-164,3$ \\
& pH & $7,11-7,34$ & $7,61-7,57$ \\
& O.D. $(\mathrm{mg} / \mathrm{L})$ & $3,9-4,3$ & $3,9-4,1$ \\
\hline
\end{tabular}

Sendo: C.E.= Condutividade elétrica e O.D.= Oxigênio dissolvido

Fonte: Própria do autor (2021)

Como abordado no tópico anterior sobre os parâmetros do teste, pode-se observar uma pequena elevação no pH da amostra, ainda que menos expressiva que para os Oligochaeta, o que é razoável se considerado que para esse teste uma menor concentração de DCF foi usada. Esse fator pode favorecer a concentração de DCF nos tecidos de C. silvestrii, uma vez que o fator de bioacumulação dessa substância aumenta com a diminuição do $\mathrm{pH}$ e o DCF tem maior propriedade de se associar à água que ao sedimento (KARLSSON, 2013). O comportamento motor de C. silvestrii, com maior movimentação que os Oligochaeta, sugere maior contato desse organismo com a contaminação por DCF na amostra, somado à sua característica de filtradora, esse fármaco pode encontrar várias rotas de ação em cladóceras. 


\subsubsection{Toxicidade para Chironomus sancticaroli}

Os resultados obtidos para C. sancticaroli estão expressos na Figura 35 para uma exposição de $96 \mathrm{~h}$ de teste.

Figura 35 - Resultado do teste toxicidade aguda do diclofenaco utilizando o inseto $C$. sancticaroli

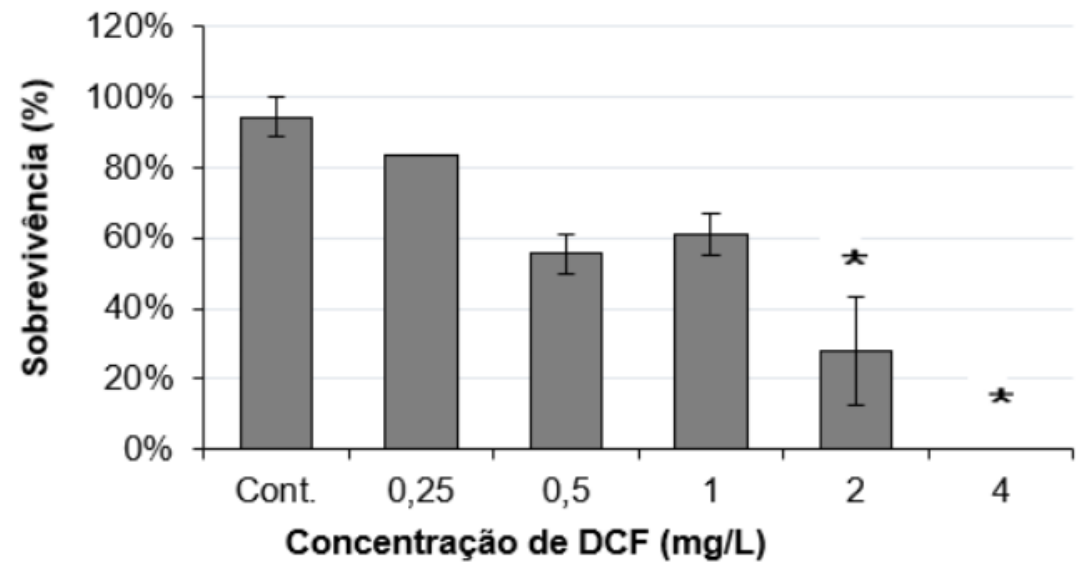

(*) Estatisticamente diferente do controle

Fonte: Própria do autor (2021)

A partir dos resultados obtidos, é possível observar que C. sancticaroli demonstrara uma alta sensibilidade a baixas concentrações de Diclofenaco, com efeito sob a sobrevivência significativa sendo observadas em concentrações a partir de 2 mg/L (Figura 35).

A espécie mais afetada pelo DCF nesta pesquisa foi C. sancticaroli apresentando valores de $\mathrm{CL}_{50}$ de $1,35 \mathrm{mg} / \mathrm{L}$, em $96 \mathrm{~h}$ de exposição. Evidências da literatura mostraram que entre a família Chironomidae a $\mathrm{CL}_{50}$ atinge $156 \mathrm{mg} / \mathrm{L}$ para Chironomus riparius (48h) (XIE et al., 2020), 105,2 mg/L para larvas de $1^{\text {O }}$ ínstar de Chironomus aprilinus (48h) (MATEJCZYK et al., 2020), $23 \mathrm{mg} / \mathrm{L}$ para larvas de $1^{\circ}$ instar de Chironomus tepperi ( 7 dias) (GONZAGO; KUMAR, 2013). As diferenças acentuadas na toxicidade das pesquisas citadas podem ser explicadas devido às diferenças no período de exposição e na idade das larvas. No entanto, a toxicidade do DCF ao C. sancticaroli nos estágios finais das larvas é maior do que nos primeiros instares com um período de exposição mais extenso. Além disso, o levantamento bibliográfico apontou C. sancticaroli como a espécie mais sensível, mesmo quando comparada a bactérias, macrófitas e embriões de peixes (CLEUVERS, 2003; CLEUVERS, 2004; PRASKOVA et al., 2011).

Os parâmetros coletados no início do teste utilizando C. sancticaroli estão representados na Tabela 25. 
Tabela 25 - Faixa de valores dos parâmetros do teste utilizando o inseto C. sancticaroli em exposição ao DCF

\begin{tabular}{llll}
\hline & Parâmetros & Tratamentos & Controle \\
\hline C. sancticaroli & C.E $(\mu \mathrm{S} / \mathrm{cm})$ & $46,6-47,5$ & $53,3-48,8$ \\
& pH & $7,06-7,30$ & $7,17-7,53$ \\
& O.D. $(\mathrm{mg} / \mathrm{L})$ & $3,8-4,5$ & $4,0-4,2$ \\
\hline
\end{tabular}

Sendo: C.E.= Condutividade elétrica e O.D.= Oxigênio dissolvido

Fonte: Própria do autor (2021)

Conforme observado na Tabela 25, a presença de concentrações baixas de DCF no meio teste não trouxe quase nenhuma alteração nas características da água de cultivo. A toxicidade da amostra aparenta ter relação com alguma reação específica do Chironomus sancticaroli ao DCF, uma vez que os parâmetros físico-químicos não apresentaram diferenças bruscas. Os organismos sobreviventes, observados na retirada do teste, foram aqueles que assim como no resultado com o esgoto doméstico, cavaram tubos e construíram casulos no sedimento, impedindo um certo contato com o DCF.

Penha et al. (2021) encontraram valores de $\mathrm{LC}_{50}$ de $5,49 \mathrm{mg} / \mathrm{L}$ para adultos do vertebrado Danio rerio, enquanto Praskova et al. (2011) encontraram valores de $\mathrm{LC}_{50}$ de $166 \mathrm{mg} / \mathrm{L}$ para a mesma espécie de mesma idade. No caso do primeiro autor, testes de ecotoxicidade subletal foram desenvolvidos, e constatado a presença de biomarcadores genotóxicos e bioquímicos nos indivíduos submetidos a concentrações ambientais. Da mesma forma, as disparidades entre a tolerância de espécies de Chironomidae só podem ser melhor elucidadas quando entendidas as reações internas desses organismos à presença do DCF.

\subsubsection{Comparação entre espécies}

Os efeitos adversos que causam a mortalidade dos organismos aquáticos quando expostos a DCF vem sendo bem discretizados na literatura para espécies de vários níveis tróficos. Ferrari et al. (2003) avaliaram o efeito do diclofenaco em diferentes níveis tróficos com a bactéria Vibrio Fischeri, a alga Raphidocelis subcapitata, e o peixe Danio rerio, e obtiveram valores de $\mathrm{CE}_{50}$ de $11,454 \mathrm{mg} / \mathrm{L}$ para Vibrio fischeri, e ainda CEO de 20 $\mathrm{mg} / \mathrm{L}$ e $8 \mathrm{mg} / \mathrm{L}$ para P. subcapitata e D. rerio, respectivamente. Como base nos resultados o autor concluiu que o diclofenaco tem baixo impacto agudo em organismos aquáticos nas concentrações atualmente encontradas, mas que testes de maiores durações podem demonstrar melhor os efeitos desse fármaco na qualidade de vida dos indivíduos, além de somente a mortalidade.

Cleuvers (2003) observou os efeitos de concentrações de miligramas por litro para 
o Cladocera Daphnia magna, a alga Desmodesmus subspicatus e macrófita Lemna minor, avaliando respostas de imobilização para o consumidor primário e inibição de crescimento para os produtores. Os resultados mostraram que a espécie mais sensível ao diclofenaco foi L. minor $\left(\mathrm{CE}_{50}=7,5 \mathrm{mg} / \mathrm{L}\right)$, seguida por D. magna $\left(\mathrm{CE}_{50}=68 \mathrm{mg} / \mathrm{L}\right)$ e depois por $D$. subspicatus $\left(\mathrm{CE}_{50}=72 \mathrm{mg} / \mathrm{L}\right)$, levando o autor a enquadrar o diclofenaco como substância tóxica e prejudicial aos organismos aquáticos.

Diniz et al. (2015) avaliou a toxicidade do subproduto do diclofenaco exposto a radiação UV no vertebrado $D$. rerio através da enzima de estresse oxidativo (glutathioneS-transferase, catalase, superóxido dismutase). Mesmo depois de um período de cinco minutos de exposição ultravioleta o diclofenaco permaneceu induzindo ao estresse oxidativo e os subprodutos da fotólise mostraram maior toxicidade que a substância original.

O diclofenaco também foi testado em misturas, por Cleuvers (2004), Stancova et al. (2014) e Dökmeci, Dökmeci e Ibar (2014) e afim de avaliar possível potencial agudo mesmo em concentrações subletais. Notou-se que a mistura de diclofenaco, carbamazepina e ibuprofeno em concentrações ambientais não altera significativamente a letalidade dos compostos (STANCOVA et al., 2014). A combinação de ibuprofeno, diclofenaco, naproxeno e ácido acetil salicílico é mais tóxica do que a ação isolada dos fármacos em termos de $\mathrm{CE}_{50}$ para algas (CLEUVERS, 2004) e bactérias (DÖKMECI; DÖKMECI; IBAR, 2014). Em casos de amostra de esgotos domésticos esses efeitos de misturas são esperados.

A curva de distribuição de sensibilidade das espécies dos estudos citados, sobre a letalidade do DCF, está expressa na Figura 36, comparados em termos de $\mathrm{CL}_{50}$ e $\mathrm{CE}_{50}$ utilizando os dados obtidos por outros autores já apresentados na Tabela 4 .

Por meio do gráfico apresentado na Figura 36 pode-se observar que dentre os organismos citados D. magna, com o $\mathrm{CE}_{50}$ de $39,9 \mathrm{mg} / \mathrm{L}$, é o organismo que representa o efeito letal a $50 \%$ da comunidade aquática, se um ecossistema fosse composto por somente esses organismos. Em outras palavras, a concentração de DCF que eliminaria metade da biota aquática presente nesse sistema seria de 39,9 mg/L. A visualização gráfica dos resultados ajuda a estimar de maneira mais aproximada os limites toleráveis de concentração de substâncias no meio ambiente, embora esses limites devam ser estabelecidos em cima de dados de toxicidade crônica, essa curva já ajuda a observar quais organismos são mais representativos para uma posterior avaliação subletal que subsidie essa tomada de decisão. 
Figura 36 - Curva de discribuição da sensibilidade das espécies aquáticas à exposição de diclofenaco $\left(\mathrm{CE}_{50}\right.$ ou $\left.\mathrm{CL}_{50}\right)$

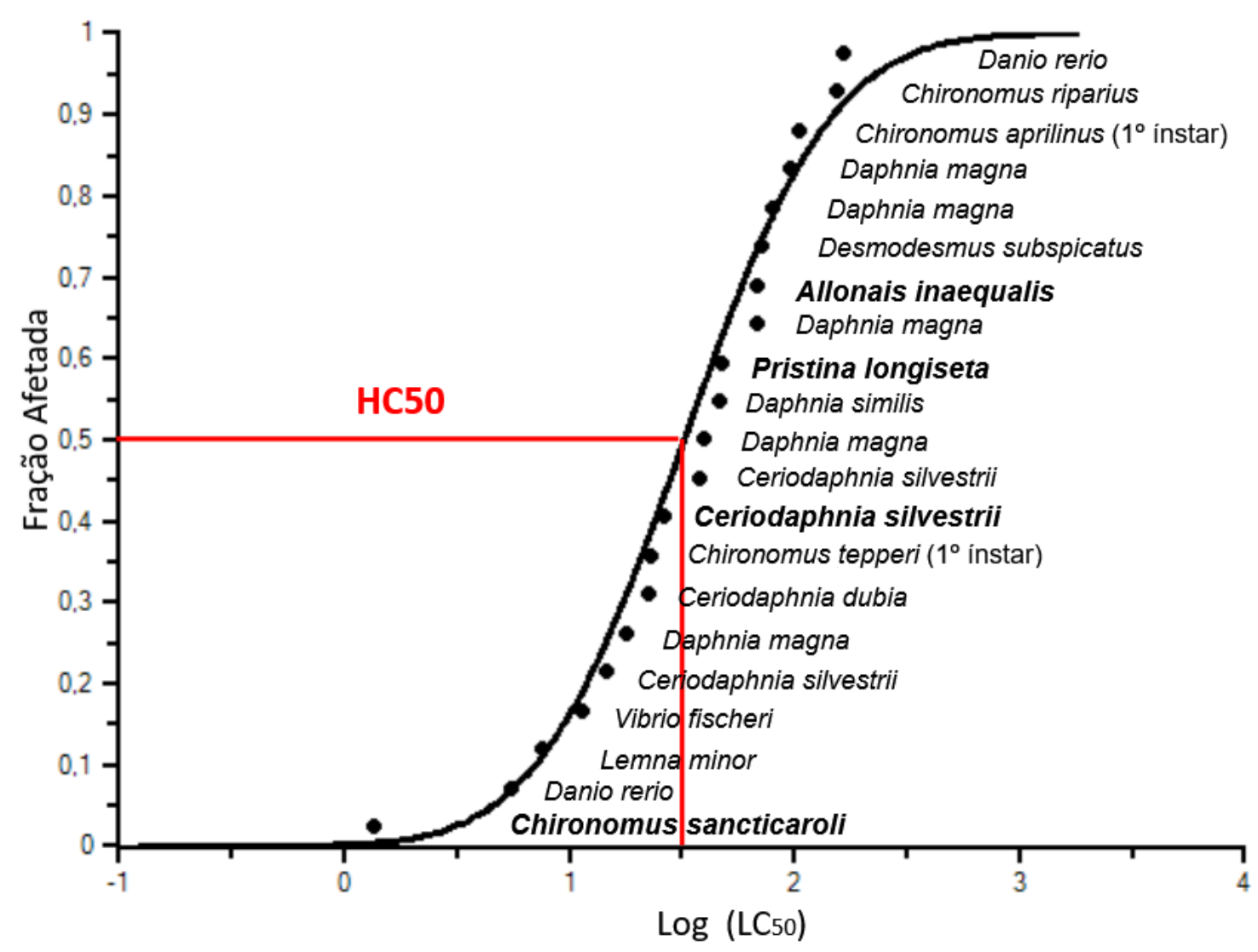

Fonte: Própria do autor (2021)

A observação dos efeitos adversos causados a organismos de várias espécies ajuda a compreender em partes a dimensão do impacto causado pela exposição do DCF no ambiente aquático. As interações e relações entre os organismos de um mesmo ecossistema são muito mais complexas e cheias de variáveis. Os efeitos do DCF em escala mais próxima da realidade (mesocosmo) foi estudada por Joachim et al. (2021) num período de seis meses expondo populações de peixes, macrófitas, mexilhões entre outros a concentrações ambientais de DCF. Observou-se uma diminuição no oxigênio dissolvido nos tratamentos com concentração mais elevada, bem como diminuição no volume de macrófitas aquáticas. As alterações letais e subletais causadas pela exposição ao DCF a esses organismos alteraram a estrutura de toda a comunidade, seja por efeitos causados pelo DCF ou por competições e predações desbalanceadas. Esses resultados apontam para a necessidade de contínuo monitoramento da presença de contaminantes nos corpos hídricos, bem como o monitoramento dos riscos associados à exposição deles para a biota aquática. 


\subsection{Toxicidade crônica do Diclofenaco (Chironomus sancticaroli)}

Os dados obtidos para toxicidade aguda do DCF nos tópicos anteriores dizem respeito a concentrações não verificadas ambientalmente. Dado a sensibilidade de Chironomus sancticaroli a baixas concentrações de DCF, ele foi selecionado como alvo de avaliação de efeitos subletais em concentrações menores, e enquadradas entre a concentração já identificadas em efluentes de unidades farmacêuticas e águas superficiais (ASHFAQ et al., 2017; HANIF et al., 2020).

\subsubsection{Sobrevivência}

As larvas de Chironomus sancticaroli, em exposições de 10 dias a concentrações de diclofenaco entre 1 e 0,1 mg/L foi expressa na Figura 37 em termos de taxa de sobrevivência.

Figura 37 - Porcentagem de sobrevivência de larvas do inseto $C$. sancticroli submetidos ao diclofenaco após 10 dias de exposição)

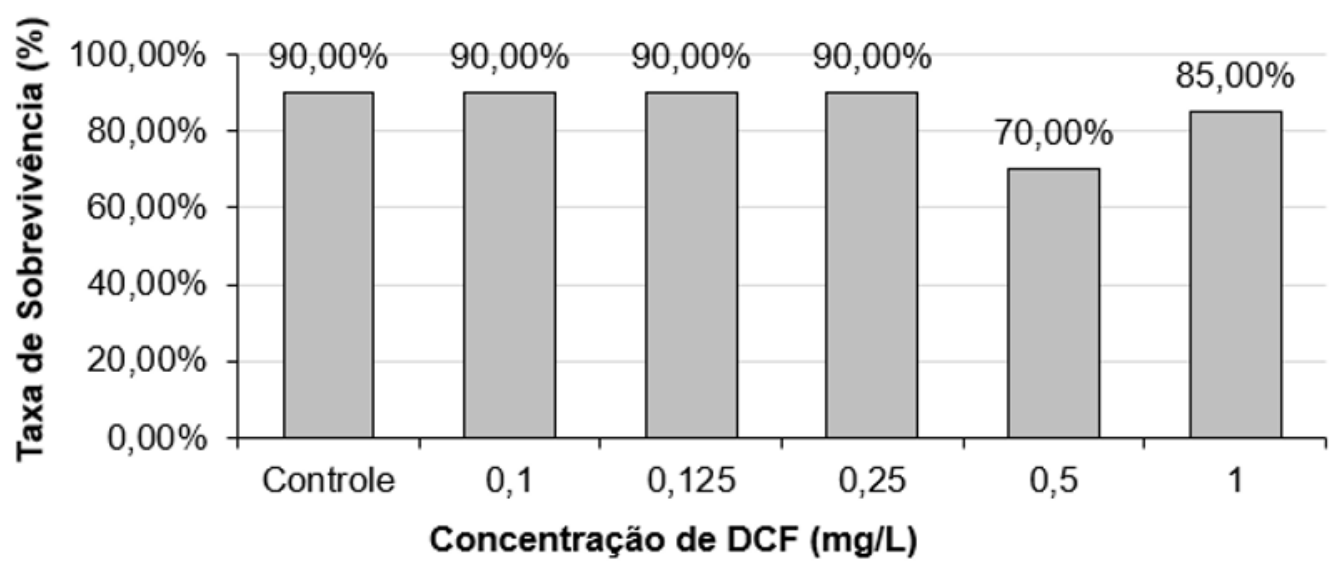

Fonte: Própria do autor (2021)

A única concentração que apresentou taxa de sobrevivência diferente da taxa do controle foi a concentração de $0,5 \mathrm{mg} / \mathrm{L}$, com taxa de $70 \%$. A concentração subsequente, apesar de maior e mais próxima da $\mathrm{CL}_{50}$ para $C$. sancticaroli, apresentou taxa de sobrevivência maior e mais parecida com a do controle. As vias de ação do fármaco devem ser mais incisivas em organismos maiores, talvez pela proporção maior de alimentação, observa-se, no entanto, a mesma retomada da sobrevivência na concentração $0,5 \mathrm{mg} / \mathrm{L}$ para $1 \mathrm{mg} / \mathrm{L}$, para as larvas de $4^{\mathrm{O}}$ instar, essa retomada foi de $56 \%$ para $61 \%$ nessas mesmas concentrações. Stepanova et al. (2013) também observaram mortalidade de 4,8\% no décimo dia para o peixe Cyprinus carpio em exposições de $1 \mathrm{mg} / \mathrm{L}$ enquanto para a menor exposição, de $0,015 \mathrm{mg} / \mathrm{L}$, essa mortalidade foi de aproximadamente $5,2 \%$. O 
diclofenaco aparenta ser mais letal em uma concentração menor, mas em concentrações um pouco maiores as espécies apresentam uma maior adaptação ao meio contaminado antes de voltar a demonstrar efeito letal.

Da mesma forma como os resultados entre as larvas de primeiro ínstar e quarto foram semelhantes, Penha et al. (2021) também encontraram valores parecidos de $\mathrm{CL}_{50}$ para organismo adulto e larvas de Danio rerio submetidas ao DCF, 5,49 mg/L e 5,22 $\mathrm{mg} / \mathrm{L}$, respectivamente. Nieto et al. (2017) estudaram a toxicidade crônica de sedimento contaminado com diclofenaco (skiped-sedment) no inseto Chironomus riparius, e não encontraram diferença estatisticamente significante na sobrevivência nem crescimento dos organismos, em concentrações efetivamente fixadas no sedimento de $2,4 \mu \mathrm{g} / \mathrm{g}$. Essas concentrações foram menores que as testadas nessa pesquisa, o que pode explicar a ausência de efeitos identificados.

\subsubsection{Comprimento larval}

Após os 10 dias de exposição as larvas foram coletadas e o comprimento dos indivíduos sobreviventes foi obtido e calculado. Os resultados estão expressos na Figura 38. O tamanho larval identificado nessa pesquisa entra em conformidade com os valores limites descritos por Trivinho-Strixino (1980) de 9,91 a 13,64mm.

Figura 38 - Comprimento corporal das larvas do inseto C. sancticroli submetidos ao diclofenaco após 11 dias de exposição

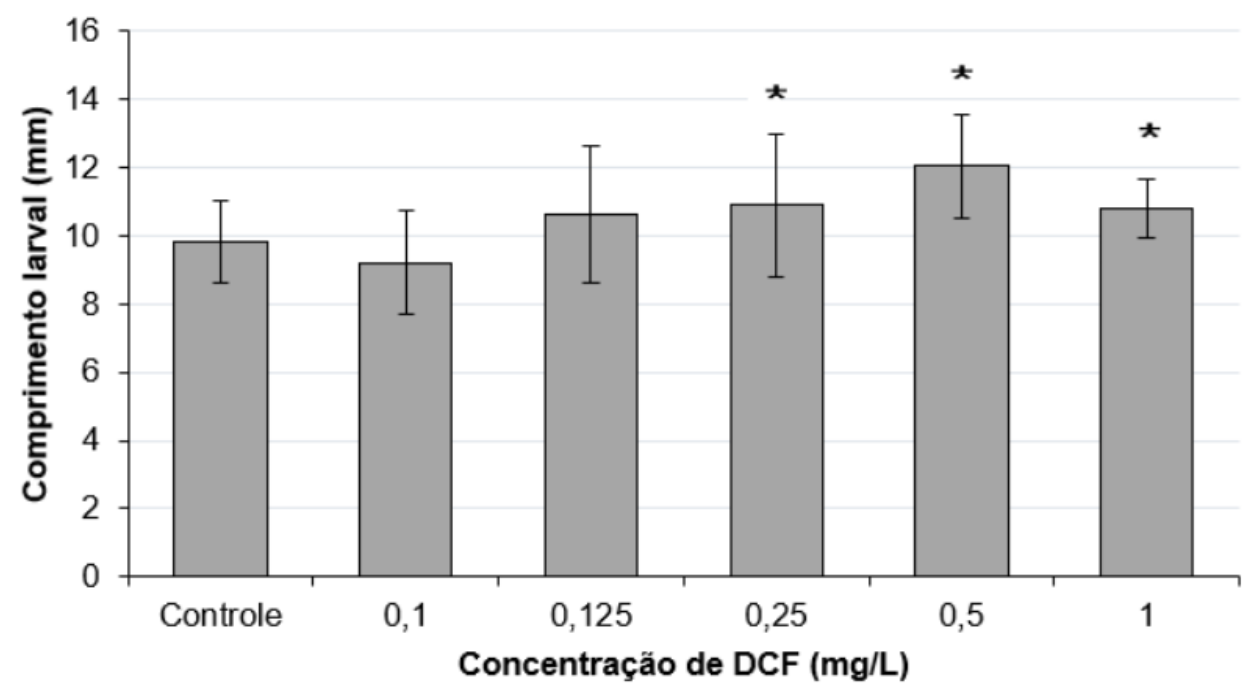

(*) Estatisticamente diferente do controle

Fonte: Própria do autor (2021)

Conforme observado na Figura 38, a presença de concentrações de DCF a partir 
de $0,25 \mathrm{mg} / \mathrm{L}$ causam efeitos estatisticamente significativos para o comprimento larval do inseto C. sancticaroli. Esse efeito foi o do aumento no comprimento larval dos indivíduos, com maior desenvolvimento observado na concentração 0,5 mg/L. Essa diferença nessa concentração pode ser explicada pela menor competição por alimento, devido ao menor número de sobreviventes remanescentes. Yokota et al. (2018) não observaram mudanças no crescimento do peixe Oryzias latipes em concentrações entre 0,608 e 94,8 $\mu \mathrm{g} / \mathrm{L}$, assim como nesse experimento, na concentração de $100 \mu \mathrm{g} / \mathrm{L}(0,1 \mathrm{mg} / \mathrm{L})$ nenhum efeito no crescimento foi observado.

Diferentemente dos resultados obtidos nessa pesquisa, o DCF dificultou o processo de crescimento de outras espécies. Stepanova et al. (2013) constataram um atraso no desenvolvimento de Cyprinus carpio nos primeiros dias de teste em concentrações de até $3 \mathrm{mg} / \mathrm{L}$, mas ao final de 30 dias nenhuma diferença foi observada. Talvez um maior tempo de contato de $C$. sancticaroli pudesse favorecer a adaptação da espécie ao meio contaminado. Praskova et al. (2014) constaram diminuição do crescimento do vertebrado Danio rerio quando submetido a concentrações a partir de $30 \mathrm{mg} / \mathrm{L}$. Na exposição de 1 mg/L, a presença de DCF prejudicou o comportamento alimentar do peixe Oryzias latipes, induzindo esse organismo a levar mais tempo para se alimentar (NASSEF et al., 2010), para C. sancticaroli a presença do DCF parece ter favorecido a alimentação.

O aumento no comprimento das larvas de C. sancticaroli pode estar relacionado a alguma via de ação específica do Diclofenaco. O diclofenaco foi desenvolvido para inibir a enzima cicloxigenase (COX), que é responsável pelo processo de síntese de prostaglandina (GAN, 2010), e esse mesmo modo de ação já foi identificado em organismos aquáticos (COURANT et al., 2018; LÓPEZ-DOVAL et al., 2020). A prostaglandina além de ser uma mediadora de processos inflamatórios, atua nas funções reprodutivas dos animais (LÓPEZ-DOVAL et al., 2020) e também está presente em insetos (STANLEY, 2006). A supressão dessa enzima, pode ter desviado as ações metabólicas de Chironomus sancticaroli, como por exemplo as ações reprodutivas, para a função de alimentação. Liu et al. (2017b) constataram que resultados de reprodução e postura de neonatos da Cladocera D. magna são melhores indicadores de efeitos adversos causados pelo DCF que os resultados de sobrevivência e crescimento. No entanto, somente investigações mais aprofundadas com o inseto Chironomus sancticaroli, analisando-se a expressão gênica, enzimática, efeitos multigeracionais, entre outros, podem esclarecer o resultado obtido.

\subsubsection{Deformidades bucais}

As imagens obtidas por meio da avaliação do mento de Chironomus sancticaroli estão apresentadas na Figura 39, para cada concentração e controle para os exemplares onde nenhuma deformidade foi verificada. Observados os números de dentes, vãos e ausências de dentes os números identificados estão detalhados na Figura 40. 
Figura 39 - Registro da morfologia bucal de exemplares de $C$. sancticaroli de cada tratamento da exposição ao diclofenaco

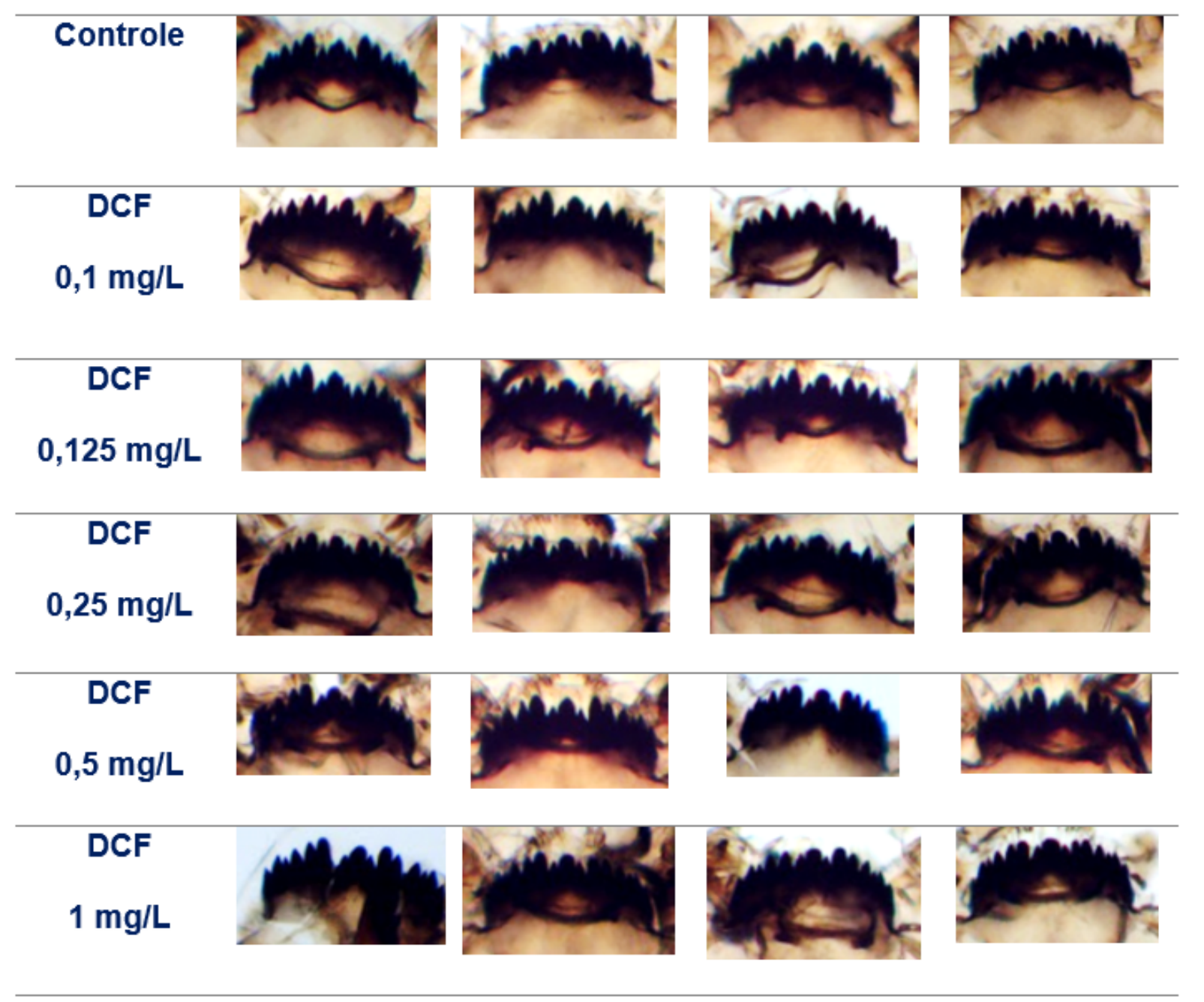

Fonte: Própria do autor (2021)

Conforme observado na Figura 40 as deformidades no mento da espécie Chironomus sancticaroli são encontradas em 31,5\% dos indivíduos do tratamento controle, valor superior ao encontrado no teste com o RALF, a presença de concentrações maiores de DCF acentuou ainda mais o efeitos aos danos na estrutura dentária de C. sancticaroli. As duas únicas concentrações que apresentaram valores muito superiores à margem do controle foi a concentração 0,1 e $1 \mathrm{mg} / \mathrm{L}$.

Yokota et al. (2018) observaram defeito nas mandíbulas do peixe Oryzias latipes a partir de concentrações de $7,29 \mu \mathrm{g} / \mathrm{L}$ de diclofenaco em exposições de 90 dias, concentração muito menor que as usadas nesse trabalho, o tempo de exposição, no entanto, pode ter sido decisivo no surgimento dessas deformidades. Parrott e Bennie (2009) encontraram 
deformidades nas larvas do peixe "Fathead minnows", em misturas de vários fármacos, todos em concentrações de nano gramas por litro. $\mathrm{O}$ fato de o diclofenaco induzir deformidades morfológica em vertebrados, em concentrações baixas já enfatiza a necessidade de atenção sobre a presença desse fármaco em corpos receptores. Os resultados obtidos através da verificação de deformidades no mentos de C. sancticaroli ratifica essa necessidade, uma vez que a concentração que é encontrada em afluentes de estações de tratamento $(0,1 \mathrm{mg} / \mathrm{L})$, e que foi injetado no RALF, oferece risco ao desenvolvimento dessa espécie, e segundo os dados dessa revisão a muitas outras.

Figura 40 - Número de deformidades bucais identificadas nas larvas de C. sancticaroli em cada tratamento utilizando o diclofenaco

\begin{tabular}{|c|c|c|c|c|c|c|c|c|c|c|c|c|c|}
\hline \multirow{3}{*}{$\begin{array}{c}\text { Concentração } \\
(\mathrm{mg} / \mathrm{L})\end{array}$} & \multirow{3}{*}{$n$} & \multicolumn{10}{|c|}{ Deformidades específicas } & \multirow{2}{*}{\multicolumn{2}{|c|}{$\begin{array}{c}\text { Total de } \\
\text { larvas } \\
\text { deformadas }\end{array}$}} \\
\hline & & \multicolumn{2}{|c|}{$\begin{array}{l}\text { Köehn } \\
\text { vão }\end{array}$} & \multicolumn{2}{|c|}{$\begin{array}{l}\text { Dentes } \\
\text { faltando }\end{array}$} & \multicolumn{2}{|c|}{$\begin{array}{l}\text { Dentes } \\
\text { sobrando }\end{array}$} & \multicolumn{2}{|c|}{$\begin{array}{l}\text { Sem } \\
\text { dentes }\end{array}$} & \multicolumn{2}{|c|}{$\begin{array}{c}\text { Dente } \\
\text { desgastado }\end{array}$} & & \\
\hline & & $n$ & $\%$ & $n$ & $\%$ & $n$ & $\%$ & $n$ & $\%$ & $n$ & $\%$ & $n$ & $\%$ \\
\hline Controle & 16 & 2 & 12,5 & 3 & 12,5 & 1 & 6,25 & 0 & 0 & 1 & 6,25 & 5 & 31,25 \\
\hline 0,1 & 16 & 1 & 6,25 & 6 & 37,5 & 1 & 6,25 & 0 & 0 & 1 & 6,25 & 7 & 43,75 \\
\hline 0,125 & 16 & 0 & 0 & 4 & 25 & 0 & 0 & 0 & 0 & 1 & 6,25 & 4 & 25 \\
\hline 0,25 & 16 & 1 & 6,25 & 3 & 18,7 & 0 & 0 & 0 & 0 & 2 & 12,5 & 5 & 31,25 \\
\hline 0,5 & 14 & 2 & 12,5 & 3 & 18,7 & 0 & 0 & 0 & 0 & 2 & 12,5 & 6 & 37,5 \\
\hline 1 & 16 & 3 & 18,7 & 4 & 25 & 1 & 6,25 & 0 & 0 & 1 & 6,25 & 8 & $50 \%$ \\
\hline
\end{tabular}

Fonte: Própria do autor (2021)

As imagens de algumas deformidades encontradas nesse teste são ilustradas na Figura 41. 
Figura 41 - Deformidades identificadas em larvas submetidas ao diclofenaco.a) vão de Köehn; b) dentes faltando; c) dentes sobrando e d) dente desgastado

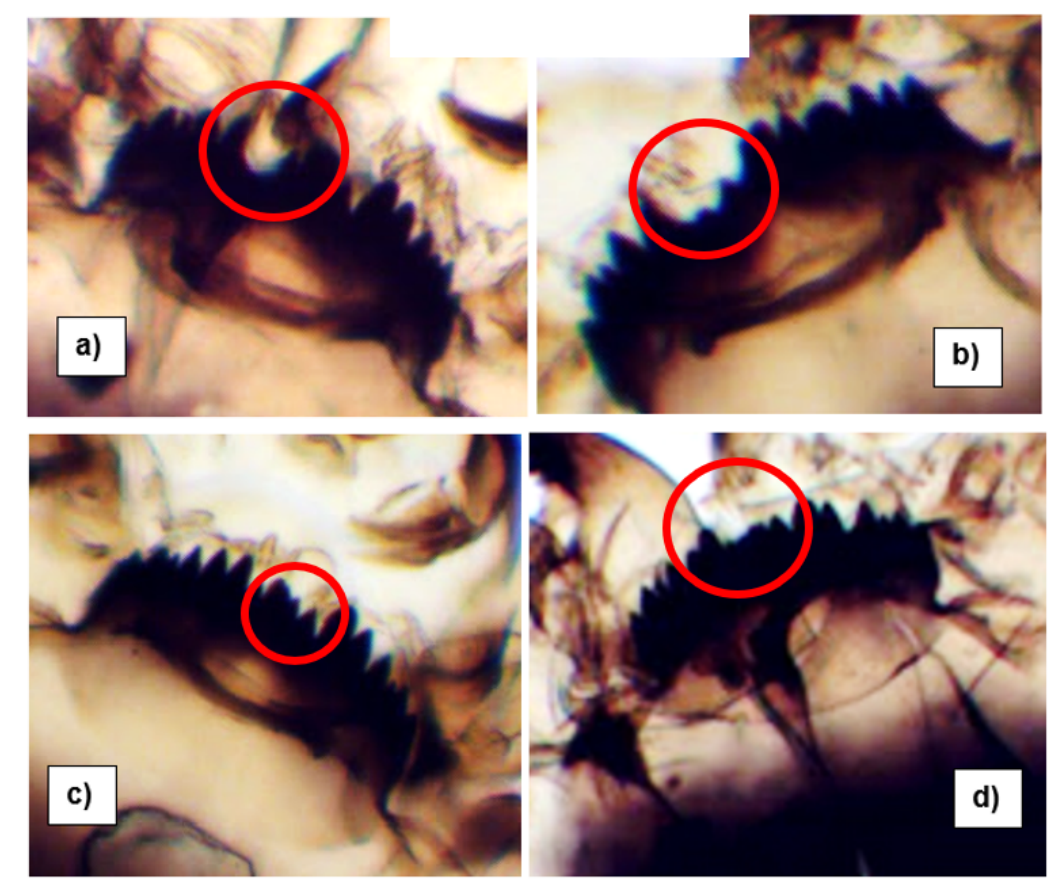

Fonte: Própria do autor (2021)

\subsection{Considerações finais}

Ao término dos testes algumas experiências foram colhidas. Por meio das análises ecotoxicológicas, foi possível verificar a eficiência do reator na remoção de componentes tóxicos à biota aquática, e observou-se que a aplicação de testes de toxicidade é uma ferramenta proveitosa como parâmetro paralelo na avaliação de efluentes. Para que essa ferramenta fomente resultados precisos, sugere-se a realização dos testes com amostras recém coletadas do reator, a experiência com o congelamento da amostra pode ter trazido resultados subestimados da toxicidade da amostra. Da mesma forma, foi imprescindível a avaliação da toxicidade do afluente em paralelo à avaliação do efluente, com o mesmo lote de animais e sob as exatas mesmas condições de teste, somente a avaliação da amostra final do efluente não demonstraria o potencial de remoção de agentes tóxicos em cada fase do reator, podendo ser uma mais tóxica em relação a outra não por deficiência na operação do reator mas por maior toxicidade inicial da amostra.

A avaliação utilizando várias espécies de invertebrados, uma inclusa no rol de organismos sugeridos pela CETESB e as demais de acordo com a seu habitat ecológico, demonstrou resultados positivos. Tanto para o teste com amostras do RALF quanto para o teste com o diclofenaco a comparação entre espécies foi diferente, o que já era esperado 
uma vez que cada organismo possui mecanismos de defesa e alimentação diferente, com esse resultado a discussão foi mais abrangente, com melhor inferência do perigo à biota aquática com menores chances de subestimação ou superestimação das respostas. As análises de toxicidade crônica foram fundamentais na confirmação e aprofundamento dos resultados obtidos. 


\section{CONCLUSÃO}

De aconrdo com os objetivos propostos observou-se a maior redução de toxicidade para A. inaequalis e $P$. longiseta foi observada na Fase I (13,00 e 8,33\%, respectivamente). Já para C. sancticaroli e C. silvestrii a maior redução da toxicidade ocorreu na Fase II e Fase III (19,46 e 22,91\%, respectivamente). Em exposições crônicas, o aumento proporcional de afluente e efluente induziu maiores danos ao desenvolvimento larval e deformidades no mentos do C. sancticaroli. O DCF apresentou toxicidade (CE50 e CL50) para o $C$. sancticaroli, A. inaequalis, $P$. longiseta e a $C$. silvestrii em escala de mg/L $(1,35 ; 68,41$; 47,49; 26,43, respectivamente). Em exposição subletal ao DCF, o C. sancticaroli sofreu alterações no comprimento larval e na formação dentária, com o aumento da concentração. Dessa forma a hipotése 1 e 2 desse trabalho foram confirmadas.

Outras observações permitiram concluir que os organismos de habitat bentônico possuem maior sensibilidade a amostras de afluente e efluente do RALF, indicando a possível presença de agentes tóxicos predominantemente no sedimento das amostras, o que sugere melhorias em fases posteriores para a decantação de sólidos sedimentáveis em outra etapa de tratamento. Alguma característica inerente aos processos de tratamento do esgoto da cidade de São Carlos precisa ser mais cuidadosamente avaliada para mitigar os seus efeitos tóxicos principalmente para macroinvertebrados bentônicos.

De maneira geral as diferentes configurações do RALF não implicaram em variações bruscas na minimização da toxicidade, ainda assim, para a maioria dos organismos o TDH de $18 \mathrm{~h}$ foi o mais favorável às suas sobrevivências. Embora a redução da toxicidade em todas as fases já sinaliza a eficiência no tratamento de esgoto sanitário para esse reator, mais estudos precisam ser desenvolvidos para que essa tecnologia seja tão bem sucedida a ponto de possibilitar um tratamento que não traga prejuízo algum à biota aquática em corpos receptores de qualquer classe e que cumpra com os demais parâmetros exigidos por lei.

Embora as concentrações de DCF que causaram mortalidade aos organismos estivessem relativamente longe das concentrações identificadas em corpos d'água, esses resultados já indicam as concentrações-limite que podem causar sérios riscos aos ambientes aquáticos. As respostas obtidas utilizando o inseto Chironomus sancticaroli nas avaliações de letalidade destaca a importância de aprofundar a investigação do impacto de fármacos em corpos d'água locais, de maneira especial as drogas antiinflamatórias não esteroidais de inibição da enzima cicloxigenase. Apesar dos dados de toxiciade crônica apresentarem mais detalhes da influência do diclofenaco no desenvolvimento do inseto aquático, os fundamentos dessa influência só poderão ser melhor esclarecidos utilizando estudos das transformações gênicas, metabolômica entre outras. Ademais, conclue-se que 
a regulamentação mundial sobre os limites permitidos de substâncias em corpos d'água deve considerar as especificidades das espécies locais de diferentes funções ecológicas.

Alguma associação entre a toxicidade encontrada nas amostras de efluente do reator e a toxicidade do DCF talvez só fosse possível através de testes de identificação da toxicidade (TIE), no entando as repostas obtidas em concentrações ambientais, e também concentraões injetadas no afluente do RALF, enfatizam a necessidade de contínuo monitoramento das quantidades desse fármaco no meio ambiente, e destacam a importância do desenvolvimento de tecnologias que investigam a retirada desse fármaco nas amostras de esgoto doméstico. 


\section{REFERÊNCIAS}

ABNT - ASSOCIAÇÃO BRASILEIRA DE NORMAS TÉCNICAS. NBR 15469: Ecotoxicologia aquática-Preservação e Preparo de amostras. Rio de Janeiro, 2007.

ABNT - ASSOCIAÇÃO BRASILEIRA DE NORMAS TÉCNICAS. NBR 12713: Ecotoxicologia aquática - Toxicidade aguda - Método de ensaio com Daphnia spp. (Crustacea, Cladocera). Rio de Janeiro, 2016.

ABNT - ASSOCIAÇÃO BRASILEIRA DE NORMAS TÉCNICAS. NBR 13373 Ecotoxicologia aquática - Toxicidade crônica - Método de ensaio com spp. (Crustacea, Cladocera). Rio de Janeiro, 2017.

ABREU, M. et al. The use of pcr-rflp to genetically distinguish the morphologically close species: Ceriodaphnia dubia richard, 1894 and Ceriodaphnia silvestrii daday, 1902 (crustacea cladocera). Brazilian Journal of Biology, SciELO Brasil, v. 70, p. 121-124, 2010.

ACERO, J. L. et al. Retention of emerging micropollutants from up water and a municipal secondary effluent by ultrafiltration and nanofiltration. Chemical Engineering Journal, Elsevier, v. 163, n. 3, p. 264-272, 2010.

AGASILD, H.; NÕGES, T. Cladoceran and rotifer grazing on bacteria and phytoplankton in two shallow eutrophic lakes: in situ measurement with fluorescent microspheres.

Journal of Plankton Research, Oxford University Press, v. 27, n. 11, p. 1155-1174, 2005.

AKPOR, O. B. et al. Pollutants in wastewater effluents: impacts and remediation processes. International Journal of Environmental Research and Earth Science, v. 3 , n. 3 , p. $050-059,2014$.

AL-SHAMI, S. et al. Chironomids of tropical rice fields in the north malaysian peninsula. Chironomus Journal of Chironomidae Research, n. 19, 2006.

AL-SHAMI, S. et al. Morphological deformities in Chironomus spp.(diptera: Chironomidae) larvae as a tool for impact assessment of anthropogenic and environmental stresses on three rivers in the juru river system, penang, malaysia. Environmental Entomology, Oxford University Press Oxford, UK, v. 39, n. 1, p. 210-222, 2010.

ALBUQUERQUE, F. P. de et al. Use of nontarget organism Chironomus sancticaroli to study the toxic effects of nanoatrazine. Ecotoxicology, Springer, v. 30, n. 4, p. 733-750, 2021.

ALKIMIN, G. et al. Effects of diclofenac and salicylic acid exposure on lemna minor: Is time a factor? Environmental research, Elsevier, v. 177, p. 108609, 2019.

ALMEIDA, I. d. S. d. et al. Avaliação de toxicidade de efluentes industriais utilizando organismos de três níveis tróficos. Universidade do Estado do Rio de Janeiro, 2013. 
ALTMAN, R. et al. Advances in nsaid development: evolution of diclofenac products using pharmaceutical technology. Drugs, Springer, v. 75, n. 8, p. 859-877, 2015.

ALVES, R. d. G.; GORNI, G. Naididae species (oligochaeta) associated with submersed aquatic macrophytes in two reservoirs (são paulo, brazil). Acta Limnologica Brasiliensia, v. 19, n. 4, p. 407-413, 2007.

AMIARD-TRIQUET, C.; AMIARD, J.; MOUNEYRAC, C. Aquatic Ecotoxicology: Advancing Tools for Dealing with Emerging Risks. Elsevier Science, 2015. ISBN 9780128011768. Disponível em: https://books.google.com.br/books?id=1-icBAAAQBAJ.

ANA - AGÊNCIA NACIONAL DAS ÁGUAS. Situação da Coleta e do tratamento de esgotos. Atlas Esgotos. 2017. Disponível em: http://atlasesgotos.ana.gov.br/.

ANDRADE, M. V. F. et al. Effects of hydraulic retention time, co-substrate and nitrogen source on laundry wastewater anionic surfactant degradation in fluidized bed reactors. Bioresource technology, Elsevier, v. 224, p. 246-254, 2017.

ANTUNES, S. C. et al. Evaluation of water column and sediment toxicity from an abandoned uranium mine using a battery of bioassays. Science of the Total Environment, Elsevier, v. 374, n. 2-3, p. 252-259, 2007.

ARMitAGE, P. D.; PINDER, L.; CRANSTON, P. The Chironomidae: biology and ecology of non-biting midges. [S.l.: s.n.]: Springer Science \& Business Media, 2012.

ASHFAQ, M. et al. Ecological risk assessment of pharmaceuticals in the receiving environment of pharmaceutical wastewater in pakistan. Ecotoxicology and environmental safety, Elsevier, v. 136, p. 31-39, 2017.

AUTHELIN, J.-R. et al. Freezing of biologicals revisited: scale, stability, excipients, and degradation stresses. Journal of pharmaceutical sciences, Elsevier, v. 109, n. 1, p. 44-61, 2020.

AVISAR, D. et al. Sorption of sulfonamides and tetracyclines to montmorillonite clay. Water, Air, \& Soil Pollution, Springer, v. 209, n. 1, p. 439-450, 2010.

BARAN, A.; TARNAWSKI, M. Assessment of heavy metals mobility and toxicity in contaminated sediments by sequential extraction and a battery of bioassays.

Ecotoxicology, Springer, v. 24, n. 6, p. 1279-1293, 2015.

BEGHELLI, F. G. de S. et al. Lethal and sublethal effects of metal-polluted sediments on Chironomus sancticaroli strixino and strixino, 1981. Ecotoxicology, Springer, v. 27, n. 3, p. 286-299, 2018.

BEHREND, R. et al. Eight years of monitoring aquatic oligochaeta from the baía and ivinhema rivers. Brazilian Journal of Biology, SciELO Brasil, v. 69, p. 559-571, 2009.

BENEBERU, G.; MENGISTOU, S. Head capsule deformities in Chironomus spp.(diptera: Chironomidae) as indicator of environmental stress in sebeta river, ethiopia. African Journal of Ecology, Wiley Online Library, v. 53, n. 3, p. 268-277, 2015.

BERNEGOSSI, A. C. et al. Chironomus sancticaroli generation test: A new methodology with a brazilian endemic insect. MethodsX, Elsevier, v. 6, p. 92-97, 2019. 
BERTHET, B. Reference species. In: Aquatic Ecotoxicology. [S.l.: s.n.]: Elsevier, 2015. p. $205-227$.

BERTOLETTI, E. Controle ecotoxicológico de efluentes líquidos no estado de são paulo. Companhia Ambiental do Estado de São Paulo-CETESB (Série manuais), 2008.

BOISSEAUX, P. et al. Immune responses in the aquatic gastropod Lymnaea stagnalis under short-term exposure to pharmaceuticals of concern for immune systems: Diclofenac, cyclophosphamide and cyclosporine a. Ecotoxicology and environmental safety, Elsevier, v. 139, p. 358-366, 2017.

BRANCHET, P. et al. Anthropic impacts on sub-saharan urban water resources through their pharmaceutical contamination (yaoundé, center region, cameroon). Science of the total environment, Elsevier, v. 660, p. 886-898, 2019.

BRASIL. Resolução n. ํ 430, de 13 de maio de 2011. dispõe sobre as condições e padrões de lançamento de efluentes, complementa e altera a resolução n. ํ 357, de 17 de março de 2005, do conselho nacional do meio ambiente-conama. Diário Oficial [da] União, Brasília, DF, 2011. ISSN 1677-7042.

BRENNAN, S. J. et al. Multi-generational effects of four selected environmental oestrogens on Daphnia magna. Chemosphere, v. 64, n. 1, p. 49-55, 2006. ISSN 0045-6535.

Disponível em: https://www.sciencedirect.com/science/article/pii/S0045653505014098.

BUITRAGO, B. H. et al. Development of an extraction and purification method for the determination of multi-class pharmaceuticals and endocrine disruptors in freshwater invertebrates. () Talanta, 2015, vol. 132, p. 373-381, Elsevier, 2015.

CALDAS, L. L. et al. Environmental risk assessment of drugs in tropical freshwaters using Ceriodaphnia silvestrii as test organism. 2021.

CAMPOS, D. et al. Responses of the aquatic midge Chironomus riparius to deet exposure. Aquatic Toxicology, Elsevier, v. 172, p. 80-85, 2016.

CAMPOS, J. R.; PEREIRA, J. A. R. et al. Reator anaeróbico de leito expandido/fluidificado. Tratamento de esgotos sanitários por processo anaeróbio e disposição controlada no solo, 1999.

CARTER, L. J.; RYAN, J. J.; BOXALL, A. B. Does uptake of pharmaceuticals vary across earthworm species? Bulletin of environmental contamination and toxicology, Springer, v. 97, n. 3, p. 316-322, 2016.

CASALI-PEREIRA, M. P. et al. Toxicity of vertimec ${ }^{\circledR} 18$ ec (active ingredient abamectin) to the neotropical cladoceran Ceriodaphnia silvestrii. Chemosphere, Elsevier, v. 139, p. 558-564, 2015.

CASTILLO, G. C.; VILA, I. C.; NEILD, E. Ecotoxicity assessment of metals and wastewater using multitrophic assays. Environmental Toxicology: An International Journal, Wiley Online Library, v. 15, n. 5, p. 370-375, 2000.

CASTRO, F. J. d. et al. Ecotoxicological assessment of four pharmaceuticals compounds through acute toxicity tests. O Mundo da Saúde, São Paulo, 2014. 
CASTRO, G. B. et al. Update on the use of pristina longiseta ehrenberg, 1828 (oligochaeta: Naididae) as a toxicity test organism. Environmental Science and Pollution Research, Springer, v. 27, n. 30, p. 38360-38369, 2020.

CATTANEO, A. et al. Ecotoxicology of nanomaterials: the role of invertebrate testing. Invertebrate survival journal, v. 6, n. 1, p. 78-97, 2009.

ČESEN, M. et al. The occurrence of contaminants of emerging concern in slovenian and croatian wastewaters and receiving sava river. Science of the Total Environment, Elsevier, v. 650, p. 2446-2453, 2019.

CHANG, F.-H. et al. Tolerance values of benthic macroinvertebrates for stream biomonitoring: assessment of assumptions underlying scoring systems worldwide. Environmental monitoring and assessment, Springer, v. 186, n. 4, p. 2135-2149, 2014.

CHAUMOT, A. et al. Ecotoxicology, aquatic invertebrates. [S.l.: s.n.]: Elsevier Inc., Academic Press, 2014.

CHERRY, D. S. et al. Potential effects of asian clam (corbicula fluminea) die-offs on native freshwater mussels (unionidae) i: water-column ammonia levels and ammonia toxicity. Journal of the North American Benthological Society, v. 24, n. 2, p. 369-380, 2005.

CHO, H.-H.; HUANG, H.; SCHWAB, K. Effects of solution chemistry on the adsorption of ibuprofen and triclosan onto carbon nanotubes. Langmuir, ACS Publications, v. 27, n. 21, p. 12960-12967, 2011.

CLARA, M. et al. The solids retention time - a suitable design parameter to evaluate the capacity of wastewater treatment plants to remove micropollutants. Water research, Elsevier, v. 39, n. 1, p. 97-106, 2005.

CLEUVERS, M. Aquatic ecotoxicity of pharmaceuticals including the assessment of combination effects. Toxicology letters, Elsevier, v. 142, n. 3, p. 185-194, 2003.

CLEUVERS, M. Mixture toxicity of the anti-inflammatory drugs diclofenac, ibuprofen, naproxen, and acetylsalicylic acid. Ecotoxicology and environmental safety, Elsevier, v. 59, n. 3, p. 309-315, 2004.

COLOMBO-CORBI, V. et al. Genetic diversity loss in Chironomus sancticaroli (diptera: Chironomidae) exposed to pyrimethanil fungicide: an analysis using rapd technique.

Water, Air, \& Soil Pollution, Springer, v. 228, n. 10, p. 1-3, 2017.

CORBI, J. J.; GORNI, G. R.; CORREA, R. C. An evaluation of Allonais inaequalis stephenson, 1911 (oligochaeta: Naididae) as a toxicity test organism. Ecotoxicology and Environmental Contamination, v. 10, n. 1, p. 7-11, 2015.

COSTA, C. R. et al. A toxicidade em ambientes aquáticos: discussão e métodos de avaliação. Química Nova, SciELO Brasil, v. 31, p. 1820-1830, 2008.

COSTA, J. B. D. et al. Toxicity on aquatic organisms exposed to secondary effluent disinfected with chlorine, peracetic acid, ozone and uv radiation. Ecotoxicology, Springer, v. 23, n. 9, p. 1803-1813, 2014. 
COURANT, F. et al. Exposure of marine mussels to diclofenac: modulation of prostaglandin biosynthesis. Environmental Science and Pollution Research, Springer, v. 25, n. 7, p. 6087-6094, 2018.

COUTO, C. F.; LANGE, L. C.; AMARAL, M. C. Occurrence, fate and removal of pharmaceutically active compounds (phacs) in water and wastewater treatment plants - a review. Journal of Water Process Engineering, Elsevier, v. 32, p. 100927, 2019.

CREWS, D.; GORE, A. C. Life imprints: living in a contaminated world. Environmental Health Perspectives, National Institute of Environmental Health Sciences, v. 119, n. 9, p. 1208-1210, 2011.

CRUZ-MORATÓ, C. et al. Degradation of pharmaceuticals in non-sterile urban wastewater by trametes versicolor in a fluidized bed bioreactor. Water research, Elsevier, v. 47, n. 14, p. 5200-5210, 2013.

CZEKALSKI, N.; DÍEZ, E. G.; BÜRGMANN, H. Wastewater as a point source of antibiotic-resistance genes in the sediment of a freshwater lake. The ISME journal, Nature Publishing Group, v. 8, n. 7, p. 1381-1390, 2014.

DALU, T. et al. Water or sediment? partitioning the role of water column and sediment chemistry as drivers of macroinvertebrate communities in an austral south african stream. Science of The Total Environment, Elsevier, v. 607, p. 317-325, 2017.

DANELLAKIS, D. et al. Olive oil mill wastewater toxicity in the marine environment: alterations of stress indices in tissues of mussel Mytilus galloprovincialis. Aquatic Toxicology, Elsevier, v. 101, n. 2, p. 358-366, 2011.

DELIBERALLI, W. et al. The effects of heavy metals on the incidence of morphological deformities in chironomidae (diptera). Zoologia (Curitiba), SciELO Brasil, v. 35, 2018.

DINIZ, M. et al. Ecotoxicity of ketoprofen, diclofenac, atenolol and their photolysis byproducts in zebrafish (Danio rerio). Science of the Total Environment, Elsevier, v. 505, p. 282-289, 2015.

DÖKMECI, A. H.; DÖKMECI, I.; IBAR, H. The determination of single and mixture toxicity at high concentrations of some acidic pharmaceuticals via Aliivibrio fischeri. Environmental Processes, Springer, v. 1, n. 2, p. 95-103, 2014.

DOSU, B. et al. The implications of social and economic barriers to safe drinking water for municipal level policy in ghana. Water International, Taylor \& Francis, v. 46, n. 3, p. 383-396, 2021.

DU, J. et al. Toxicity thresholds for diclofenac, acetaminophen and ibuprofen in the water flea Daphnia magna. Bulletin of environmental contamination and toxicology, Springer, v. 97, n. 1, p. 84-90, 2016.

DÜPONT, A.; LOBO, E. A. Evaluation of the efficiency of the sewage treatment plant from the university of santa cruz do sul (unisc), rs, brazil. Acta Limnologica Brasiliensia, SciELO Brasil, v. 24, p. 119-126, 2012.

ERSÉUS, C. Phylogeny of oligochaetous clitellata. Hydrobiologia, Springer, v. 535, n. 1, p. 357-372, 2005. 
FARINELLI, G. et al. Evaluation of fenton and modified fenton oxidation coupled with membrane distillation for produced water treatment: Benefits, challenges, and effluent toxicity. Science of The Total Environment, Elsevier, p. 148953, 2021.

FARRÉ, M. et al. Assessment of the acute toxicity of triclosan and methyl triclosan in wastewater based on the bioluminescence inhibition of vibrio fischeri. Analytical and Bioanalytical Chemistry, Springer, v. 390, n. 8, p. 1999-2007, 2008.

FATH, B. Encyclopedia of Ecology. Elsevier Science, 2018. ISBN 9780444641304. Disponível em: https://books.google.com.br/books?id=x1h7DwAAQBAJ.

FEITO, R.; VALCÁRCEL, Y.; CATALÁ, M. Biomarker assessment of toxicity with miniaturised bioassays: diclofenac as a case study. Ecotoxicology, Springer, v. 21, n. 1, p. 289-296, 2012.

FELIPE, M. et al. The use of an Allonais inaequalis reproduction test as an ecotoxicological bioassay. Ecotoxicology, Springer, v. 29, p. 634-638, 2020.

FELIPE, M. C. Bioensaios de toxicidade utilizando invertebrados aquáticos em exposição ao Alquilbenzeno Linear Sulfonado. 2019. Tese (Doutorado) Universidade de São Paulo, 2019.

FERRARI, B. et al. Ecotoxicological impact of pharmaceuticals found in treated wastewaters: study of carbamazepine, clofibric acid, and diclofenac. Ecotoxicology and environmental safety, Elsevier, v. 55, n. 3, p. 359-370, 2003.

FERRINGTON, L. C. Global diversity of non-biting midges (chironomidae; insectadiptera) in freshwater. In: Freshwater animal diversity assessment. [S.l.: s.n.]: Springer, 2007. p. 447-455.

FONSECA, A. Avaliação da qualidade da água do rio Piracicaba/SP através de testes de toxicidade com invertebrados. 1997. Tese (Doutorado) - PhD Thesis, EESCUSP, São Carlos, 1997.

FONSECA, A.; ROCHA, O. The life-cycle of Ceriodaphnia silvestrii daday, 1902, a neotropical endemic species (crustacea, cladocera, daphnidae). Acta Limnologica Brasiliensia, v. 16, n. 4, p. 319-328, 2004.

FONTES, M. K. et al. A tiered approach to assess effects of diclofenac on the brown mussel Perna perna: A contribution to characterize the hazard. Water research, Elsevier, v. 132, p. 361-370, 2018.

FRAM, M. S.; BELITZ, K. Occurrence and concentrations of pharmaceutical compounds in groundwater used for public drinking-water supply in california. Science of the Total Environment, Elsevier, v. 409, n. 18, p. 3409-3417, 2011.

FREIRE, F. B. Tratamento anaeróbio de efluente contendo pentaclorofenol em reator de leito fluidificado. 2005. Tese (Doutorado) — Universidade de São Paulo, 2005.

FU, Q. et al. Metabolomic profiling and toxicokinetics modeling to assess the effects of the pharmaceutical diclofenac in the aquatic invertebrate Hyalella azteca. Environmental Science \& Technology, ACS Publications, 2021. 
GAN, T. J. Diclofenac: an update on its mechanism of action and safety profile. Current medical research and opinion, Taylor \& Francis, v. 26, n. 7, p. 1715-1731, 2010.

GERHARDT, A. Aquatic behavioral ecotoxicology - prospects and limitations. Human and Ecological Risk Assessment, Taylor \& Francis, v. 13, n. 3, p. 481-491, 2007.

GEROSA, L. E. Remoção e degradação de alquilbenzeno linear sulfonado de efluente urbano em reator de leito fluidificado em escala piloto. Tese (Doutorado) — Universidade de São Paulo.

GHERNAOUT, D. Water reuse (wr): The ultimate and vital solution for water supply issues. International Journal of Sustainable Development Research, v. 3, n. 4, p. $36,2017$.

GHERNAOUT, D.; ELBOUGHDIRI, N. Water reuse: Emerging contaminants elimination - progress and trends. Open Access Library Journal, Scientific Research Publishing, v. 6, n. 12, p. 1-9, 2019.

GHOLAMI-BORUJENI, F.; NEJATZADEH-BARANDOZI, F.; AGHDASI, H. Data on effluent toxicity and physicochemical parameters of municipal wastewater treatment plant using Daphnia magna. Data in brief, Elsevier, v. 19, p. 1837-1843, 2018.

GILLESPIE, R. G.; RODERICK, G. K. Geology and climate drive diversification. Nature, Nature Publishing Group, v. 509, n. 7500, p. 297-298, 2014.

GOGOI, A. et al. Occurrence and fate of emerging contaminants in water environment: a review. Groundwater for Sustainable Development, Elsevier, v. 6, p. 169-180, 2018.

GÓMEZ-OLIVÁN, L. M. et al. Genotoxic response and oxidative stress induced by diclofenac, ibuprofen and naproxen in Daphnia magna. Drug and chemical toxicology, Taylor \& Francis, v. 37, n. 4, p. 391-399, 2014.

GONZAGO, D.; KUMAR, A. Effect assessment of pharmaceuticals using the midge larvae, Chironomus tepperi.). In: . SETAC, 2013. Disponível em: https://publications.csiro.au/publications/publication/PIcsiro:EP136762.

GONZÁLEZ-ALONSO, S. et al. Occurrence of pharmaceutical, recreational and psychotropic drug residues in surface water on the northern antarctic peninsula region. Environmental Pollution, Elsevier, v. 229, p. 241-254, 2017.

GOPAL, C. M. et al. Seasonal occurrence and risk assessment of pharmaceutical and personal care products in bengaluru rivers and lakes, india. Journal of Environmental Chemical Engineering, Elsevier, v. 9, n. 4, p. 105610, 2021.

GORNI, G.; ALVES, R. d. G. Naididae species (annelida: Oligochaeta) associated with the sponge Metania spinata (carter, 1881)(porifera: Metaniidae) from a southeastern reservoir. Acta Limnologica Brasiliensia, v. 20, n. 3, p. 261-263, 2008.

GOVENDER, T.; BARNES, J. M.; PIEPER, C. H. Contribution of water pollution from inadequate sanitation and housing quality to diarrheal disease in low-cost housing settlements of cape town, south africa. American Journal of Public Health, American Public Health Association, v. 101, n. 7, p. e4-e9, 2011. 
GROSS, M. A. Wastewater characterization. University Curriculum Development for Decentralized Wastewater Management, 2005.

GUTiERrEZ, M. F.; GAGNETEN, A. M.; PAGGI, J. C. Exposure to sublethal chromium and endosulfan alter the diel vertical migration (dvm) in freshwater zooplankton crustaceans. Ecotoxicology, Springer, v. 21, n. 1, p. 37-47, 2012.

HAAP, T.; TRIEBSKORN, R.; KÖHLER, H.-R. Acute effects of diclofenac and dmso to Daphnia magna: immobilisation and hsp70-induction. Chemosphere, Elsevier, v. 73, n. 3, p. 353-359, 2008.

HÄDER, D.-P. Ecotoxicological monitoring of wastewater. In: Bioassays. [S.l.: s.n.]: Elsevier, 2018. p. 369-386.

HANIF, H. et al. Environmental risk assessment of diclofenac residues in surface waters and wastewater: a hidden global threat to aquatic ecosystem. Environmental monitoring and assessment, Springer, v. 192, n. 4, p. 1-12, 2020.

HANSON, M. et al. How we can make ecotoxicology more valuable to environmental protection. Science of The Total Environment, v. 578, p. 228-235, 2017.

ISSN 0048-9697. Disponível em: https://www.sciencedirect.com/science/article/pii/ S004896971631614X.

HAYASHI-MARTINS, L. et al. "in vitro" evaluation of the bacterivore potential of three cladoceran species occurring in tropical and subtropical regions. Brazilian Journal of Biology, SciELO Brasil, v. 77, p. 840-847, 2017.

HELMUTH, B. et al. Organismal climatology: analyzing environmental variability at scales relevant to physiological stress. Journal of Experimental Biology, v. 213, n. 6, p. 995-1003, 03 2010. ISSN 0022-0949. Disponível em: https://doi.org/10.1242/jeb.038463.

HENZE, M.; COMEAU, Y. Wastewater characterization. Biological wastewater treatment: Principles modelling and design, IWA Publishing: London, UK, p. 33-52, 2008.

HICKMAN, D. A.; DEGENSTEIN, J. C.; RIBEIRO, F. H. Fundamental principles of laboratory fixed bed reactor design. Current Opinion in Chemical Engineering, Elsevier, v. 13, p. 1-9, 2016.

HICKS, D. B.; DEWITT, J. W. Effects of dissolved oxygen on kraft pulp mill effluent toxicity. Water Research, v. 5, n. 9, p. 693-701, 1971. ISSN 0043-1354. Disponível em: https://www.sciencedirect.com/science/article/pii/0043135471900911.

HOEGER, B. et al. Water-borne diclofenac affects kidney and gill integrity and selected immune parameters in brown trout (Salmo trutta f. fario). Aquatic Toxicology, Elsevier, v. 75, n. 1, p. 53-64, 2005.

HYNE R. V., P. A. P. D. L. . R. S. M. Increased fecundity of the cladoceran Moinodaphnia macleayi on a diet supplemented with a green alga, and its use in uranium toxicity tests. Australian Journal of Marine and Freshwater Research, CSIRO Publishing, v. 44, n. 3, p. $389-399,1993$. 
IBANEZ, T. et al. Regional forcing explains local species diversity and turnover on tropical islands. Global Ecology and Biogeography, v. 27, n. 4, p. 474-486, 2018. Disponível em: https://onlinelibrary.wiley.com/doi/abs/10.1111/geb.12712.

ISSA, C. G. Testes ecotoxicológicos para avaliação do potencial impacto ambiental em corpos receptores por efluente de Estação de Tratamento de Esgoto. 2019. Tese (Doutorado) — Universidade de São Paulo, 2019.

JEWELL, K. S. et al. Transformation of diclofenac in hybrid biofilm-activated sludge processes. Water research, Elsevier, v. 105, p. 559-567, 2016.

JOACHIM, S. et al. Effects of diclofenac on sentinel species and aquatic communities in semi-natural conditions. Ecotoxicology and Environmental Safety, Elsevier, v. 211, p. $111812,2021$.

JOHNSON, A. C. et al. Do concentrations of ethinylestradiol, estradiol, and diclofenac in european rivers exceed proposed eu environmental quality standards? Environmental science \& technology, ACS Publications, v. 47, n. 21, p. 12297-12304, 2013.

JR, A. L. B.; JR, J. R. V. Toxicity studies using freshwater benthic macroinvertebrates. 1993.

KARLSSON, M. V. Uptake of pharmaceuticals and personal care products from sediments into aquatic organisms. 2013. Tese (Doutorado) - University of York, 2013.

KLAMERTH, N. et al. Degradation of fifteen emerging contaminants at $\mu \mathrm{g}$ l- 1 initial concentrations by mild solar photo-fenton in mwtp effluents. Water research, Elsevier, v. 44, n. 2, p. 545-554, 2010.

KOT-WASIK, A.; JAKIMSKA, A.; ŚLIWKA-KASZYŃSKA, M. Occurrence and seasonal variations of 25 pharmaceutical residues in wastewater and drinking water treatment plants. Environmental monitoring and assessment, Springer, v. 188, n. 12, p. 1-13, 2016.

KRULL, M.; BARROS, F. Key issues in aquatic ecotoxicology in brazil: a critical review. Ecotoxicology and Environmental Contamination, v. 7, n. 2, 2012.

KUMAR, K. H.; KIRAN, B. A report on diversity of cladocera in sewage fed tank of bhadravathi taluk, karnataka. Int. J. Fauna Biol. Stud, v. 3, p. 18-20, 2016.

KUSUI, T.; ITATSU, Y.; JIN, J. Whole effluent toxicity assessment of industrial effluents. In: Toxicity and Biodegradation Testing. [S.l.: s.n.]: Springer, 2017. p. 331-347.

LANCHEROS, J. C. et al. Ibuprofen and naproxen removal from domestic wastewater using a horizontal subsurface flow constructed wetland coupled to ozonation. Ecological Engineering, Elsevier, v. 135, p. 89-97, 2019.

LAWRENCE, J. R. et al. Structural and functional responses of river biofilm communities to the nonsteroidal anti-inflammatory diclofenac. Environmental Toxicology and

Chemistry: An International Journal, Wiley Online Library, v. 26, n. 4, p. 573-582, 2007. 
LI, X. et al. Occurrence of quaternary ammonium compounds (qacs) and their application as a tracer for sewage derived pollution in urban estuarine sediments. Environmental pollution, Elsevier, v. 185, p. 127-133, 2014.

LIANG, J. et al. Toxicity evaluation of textile dyeing effluent and its possible relationship with chemical oxygen demand. Ecotoxicology and environmental safety, Elsevier, v. 166, p. 56-62, 2018.

LIBRALATO, G.; ANNAMARIA, V. G.; FRANCESCO, A. How toxic is toxic? a proposal for wastewater toxicity hazard assessment. Ecotoxicology and environmental safety, Elsevier, v. 73, n. 7, p. 1602-1611, 2010.

LIU, G. et al. Potential impacts of changing supply-water quality on drinking water distribution: A review. Water research, Elsevier, v. 116, p. 135-148, 2017.

LIU, Y. et al. Toxic effects of diclofenac on life history parameters and the expression of detoxification-related genes in Daphnia magna. Aquatic toxicology, Elsevier, v. 183, p. 104-113, 2017.

LONAPPAN, L. et al. Diclofenac and its transformation products: environmental occurrence and toxicity-a review. Environment International, Elsevier, v. 96, p. 127-138, 2016.

LÓPEZ-DOVAL, J. C. et al. Diet quality and nsaids promote changes in formation of prostaglandins by an aquatic invertebrate. Chemosphere, Elsevier, v. 257, p. 126892, 2020 .

LU, M.-C. et al. Occurrence and treatment efficiency of pharmaceuticals in landfill leachates. Waste Management, Elsevier, v. 55, p. 257-264, 2016.

LUO, Y. et al. Disinfection by-products formation and acute toxicity variation of hospital wastewater under different disinfection processes. Separation and Purification Technology, Elsevier, v. 238, p. 116405, 2020.

MA, K. et al. Toxicity evaluation of wastewater collected at different treatment stages from a pharmaceutical industrial park wastewater treatment plant. Chemosphere, Elsevier, v. 158, p. 163-170, 2016.

MACEDA-VEIGA, A. et al. Chronic effects of temperature and nitrate pollution on Daphnia magna: Is this cladoceran suitable for widespread use as a tertiary treatment? Water research, Elsevier, v. 83, p. 141-152, 2015.

MACEDO, T. Z. Reator de leito fluidificado em escala aumentada para tratamento de água residuária de lavanderia comercial em co-digestão com esgoto doméstico: otimização das condições operacionais e caracterização taxonômica e funcional dos microrganismos do biofilme. 2019. Tese (Doutorado) — Universidade de São Paulo, 2019.

MAGALHÃES, D. d. P.; FILHO, A. d. S. F. et al. A ecotoxicologia como ferramenta no biomonitoramento de ecossistemas aquáticos. Universidade Federal do Rio de Janeiro, 2008 . 
MAGDEBURG, A.; STALTER, D.; OEHLMANN, J. Whole effluent toxicity assessment at a wastewater treatment plant upgraded with a full-scale post-ozonation using aquatic key species. Chemosphere, Elsevier, v. 88, n. 8, p. 1008-1014, 2012.

MAGDEBURG, A. et al. Evaluating the efficiency of advanced wastewater treatment: target analysis of organic contaminants and (geno-) toxicity assessment tell a different story. Water Research, Elsevier, v. 50, p. 35-47, 2014.

MANSANO, A. S. et al. Acute and chronic toxicity of diuron and carbofuran to the neotropical cladoceran Ceriodaphnia silvestrii. Environmental Science and Pollution Research, Springer, v. 25, n. 14, p. 13335-13346, 2018.

MANSANO, A. S. et al. Toxicity of copper oxide nanoparticles to neotropical species Ceriodaphnia silvestrii and Hyphessobrycon eques. Environmental Pollution, Elsevier, v. 243 , p. $723-733,2018$.

MARA, D. Domestic wastewater treatment in developing countries. [S.l.: s.n.]: Routledge, 2013.

MARZIO, W. D. et al. Risk assessment of domestic and industrial effluents unloaded into a freshwater environment. Ecotoxicology and environmental safety, Elsevier, v. 61, n. 3, p. 380-391, 2005.

MATEJCZYK, M. et al. The study of biological activity of transformation products of diclofenac and its interaction with chlorogenic acid. Journal of Environmental Sciences, Elsevier, v. 91, p. 128-141, 2020.

MELO, E. D. d. Avaliação e identificação da toxicidade de efluentes líquidos de uma indústria de cosméticos. Universidade Federal de Viçosa, 2012.

MELO-GUIMARÃES, A. et al. Removal and fate of emerging contaminants combining biological, flocculation and membrane treatments. Water science and technology, IWA Publishing, v. 67, n. 4, p. 877-885, 2013.

METCALF, L.; EDDY, H. P.; TCHOBANOGLOUS, G. Wastewater engineering: treatment, disposal, and reuse. [S.l.: s.n.]: McGraw-Hill New York, 1991. v. 4.

MICHAEL-KORDATOU, I. et al. Dissolved effluent organic matter: characteristics and potential implications in wastewater treatment and reuse applications. Water Research, Elsevier, v. 77, p. 213-248, 2015.

MINGUEZ, L. et al. Toxicities of 48 pharmaceuticals and their freshwater and marine environmental assessment in northwestern france. Environmental Science and Pollution Research, Springer, v. 23, n. 6, p. 4992-5001, 2016.

MOLINERI, C. et al. Indicative value of different taxonomic levels of chironomidae for assessing the water quality. Ecological Indicators, Elsevier, v. 108, p. 105703, 2020.

MOLYNEUX, S.; STEC, A. A.; HULL, T. R. The effect of gas phase flame retardants on fire effluent toxicity. Polymer degradation and stability, Elsevier, v. 106, p. 36-46, 2014.

MORAIS, G. d. S. et al. Genotoxic effect of phenanthrene on Chironomus sancticaroli (diptera: Chironomidae). Zoologia (Curitiba), SciELO Brasil, v. 31, p. 323-328, 2014. 
MOREIRA, R. A. et al. A comparative study of the acute toxicity of the herbicide atrazine to cladocerans Daphnia magna, Ceriodaphnia silvestrii and Macrothrix flabelligera. Acta Limnologica Brasiliensia, SciELO Brasil, v. 26, p. 1-8, 2014.

MOTTERAN, F. Caracterização da comunidade microbiana de reator anaeróbio de leito fluidificado envolvida na degradação de surfactante não iônico álcool etoxilado de cadeia não ramificada (GENAPOL). 2013. Tese (Doutorado) Universidade de São Paulo, 2013.

MOUNT, D.; NORBERG, u. T. A seven-day life cycle cladoceran toxicity test. Environmental Toxicology and Chemistry: An International Journal, Wiley Online Library, v. 3, n. 3, p. 425-434, 1984.

MOUNT, D. I. Methods for Aquatic Toxicity Identification Evaluations: Phase I: Toxicity Characterization Procedures. [S.l.: s.n.]: US Environmental Protection Agency, Environmental Research Laboratory ..., 1988. v. 88.

MUNARI, M. et al. Coping with seawater acidification and the emerging contaminant diclofenac at the larval stage: A tale from the clam ruditapes philippinarum.

Chemosphere, Elsevier, v. 160, p. 293-302, 2016.

MURRAY, A. L. et al. Evaluation of consistent use, barriers to use, and microbiological effectiveness of three prototype household water treatment technologies in haiti, kenya, and nicaragua. Science of The Total Environment, v. 718, p. 134685, 2020. ISSN 0048-9697. Disponível em: https://www.sciencedirect.com/science/article/pii/S0048969719346765.

MUSHTAQ, N. et al. Freshwater contamination: sources and hazards to aquatic biota. In: Fresh Water Pollution Dynamics and Remediation. [S.l.: s.n.]: Springer, 2020. p. $27-50$.

NADDY, R. B. et al. Identifying the cause of toxicity in an algal whole effluent toxicity study-an unanticipated toxicant. Chemosphere, Elsevier, v. 85, n. 6, p. 1026-1032, 2011.

NANTABA, F. et al. Occurrence, distribution, and ecotoxicological risk assessment of selected pharmaceutical compounds in water from lake victoria, uganda. Chemosphere, Elsevier, v. 239, p. 124642, 2020.

NASSEF, M. et al. Acute effects of triclosan, diclofenac and carbamazepine on feeding performance of japanese medaka fish (Oryzias latipes). Chemosphere, Elsevier, v. 80, n. 9, p. 1095-1100, 2010.

NATIONAL CENTER FOR BIOTECHNOLOGY INFORMATION. Compound Summary for CID 3033, Diclofenac. 2021. Disponível em: https://pubchem.ncbi. nlm.nih.gov/compound/Diclofenac.

NAVA-ÁLVAREZ, R. et al. Oxidative stress induced by mixture of diclofenac and acetaminophen on common carp (Cyprinus carpio). Water, Air, \& Soil Pollution, Springer, v. 225, n. 2, p. 1-9, 2014.

NEWMAN, M. C. Fundamentals of ecotoxicology: the science of pollution. [S.l.: s.n.]: CRC press, 2019. 
NIETO, E. et al. Effects of exposure to pharmaceuticals (diclofenac and carbamazepine) spiked sediments in the midge, Chironomus riparius (diptera, chironomidae). Science of The Total Environment, Elsevier, v. 609, p. 715-723, 2017.

NOGUEIRA, V. et al. Toxicity of solid residues resulting from wastewater treatment with nanomaterials. Aquatic Toxicology, Elsevier, v. 165, p. 172-178, 2015.

NORBERG-KING, T. et al. Methods for aquatic toxicity identification evaluations. Phase 1. Toxicity characterization procedures. [S.l.], 1991.

NØRGAARD, L. S.; ROSLEV, P. Inhibitory effects of ammonia on filtering of commensal and pathogenic escherichia coli by the cladoceran Daphnia magna. 2017.

NTOUGIAS, S. et al. The effects of olives harvest period and production year on olive mill wastewater properties-evaluation of pleurotus strains as bioindicators of the effluent's toxicity. Chemosphere, Elsevier, v. 92, n. 4, p. 399-405, 2013.

O'FLYNN, D. et al. A review of pharmaceutical occurrence and pathways in the aquatic environment in the context of a changing climate and the covid-19 pandemic. Analytical Methods, Royal Society of Chemistry, v. 13, n. 5, p. 575-594, 2021.

OLAITAN, O. J. et al. Determination of pharmaceutical compounds in surface and underground water by solid phase extraction-liquid chromatography. Journal of Environmental Chemistry and Ecotoxicology, Academic Journals, v. 6, n. 3, p. 20-26, 2014.

OLIVEIRA, E. M.; GOLDIM, J. R. Animal protection legislation for scientific purposes and the non-inclusion of invertebrates a bioethical analysis. Revista Bioética, SciELO Brasil, v. 22, n. 1, p. 45-56, 2014.

OLIVEIRA, M. et al. Toxicological evaluation of the organophosphate trichlorfon for the fish Xiphophorus maculatus used as bioindicator. In: SOCIEDADE BRASILEIRA DE ZOOTECNIA-SBZ, ASSOCIAÇÃO BRASILEIRA DOS ZOOTECNISTAS. 55a Reunião Anual da Sociedade Brasileira de Zootecnia, $28^{\circ}$ Congresso Brasileiro de Zootecnia, Goiânia, Brasil, 27 a 30 de agosto de 2018. [S.l.: s.n.], 2018.

ONU - ORGANIZAÇÃO DAS NAÇÕES UNIDAS. Banco Mundial: esgoto tratado beneficia a saúde, o meio ambiente e a economia. ONU News. [S.l.], 2020. Disponível em: https://news.un.org/pt/story/2020/03/1707982.

OUDA, M. et al. Emerging contaminants in the water bodies of the middle east and north africa (mena): A critical review. Science of The Total Environment, Elsevier, p. $142177,2020$.

OVIEDO-GÓMEZ, D. G. C. et al. Diclofenac-enriched artificial sediment induces oxidative stress in Hyalella azteca. Environmental Toxicology and Pharmacology, Elsevier, v. 29, n. 1, p. 39-43, 2010.

ÖZPOLAT, B. D. et al. Plasticity and regeneration of gonads in the annelid Pristina leidyi. EvoDevo, BioMed Central, v. 7, n. 1, p. 1-15, 2016.

PALACIO-CORTÉS, A. M. et al. Polybrominated diphenyl ethers (pbdes) effects on Chironomus sancticaroli larvae after short-term exposure. Ecotoxicology and environmental safety, Elsevier, v. 139, p. 308-315, 2017. 
PARK, K.; KWAK, I.-S. Characterization of heat shock protein 40 and 90 in Chironomus riparius larvae: effects of di (2-ethylhexyl) phthalate exposure on gene expressions and mouthpart deformities. Chemosphere, Elsevier, v. 74, n. 1, p. 89-95, 2008.

PAROLINI, M.; BINELLI, A.; PROVINI, A. Assessment of the potential cyto-genotoxicity of the nonsteroidal anti-inflammatory drug (nsaid) diclofenac on the zebra mussel (dreissena polymorpha). Water, Air, \& Soil Pollution, Springer, v. 217, n. 1, p. 589-601, 2011.

PARROTT, J.; BENNIE, D. Life-cycle exposure of fathead minnows to a mixture of six common pharmaceuticals and triclosan. Journal of Toxicology and Environmental Health, Part A, Taylor \& Francis, v. 72, n. 10, p. 633-641, 2009.

PARUCH, L.; PARUCH, A. M.; SøRHEIM, R. Dna-based faecal source tracking of contaminated drinking water causing a large campylobacter outbreak in norway 2019. International Journal of Hygiene and Environmental Health, v. 224, p. 113420, 2020. ISSN 1438-4639. Disponível em: https://www.sciencedirect.com/science/article/pii/ S1438463919308338.

PENG, F.-J. et al. Occurrence and ecological risk assessment of emerging organic chemicals in urban rivers: Guangzhou as a case study in china. Science of the Total Environment, Elsevier, v. 589, p. 46-55, 2017.

PENHA, L. C. de C. et al. Effects of anti-inflammatory diclofenac assessed by toxicity tests and biomarkers in adults and larvae of Danio rerio. Comparative Biochemistry and Physiology Part C: Toxicology \& Pharmacology, Elsevier, v. 242, p. 108955, 2021.

PEREIRA, A. et al. Selected pharmaceuticals in different aquatic compartments: Part $\mathrm{i}$ - source, fate and occurrence. Molecules, Multidisciplinary Digital Publishing Institute, v. 25, n. 5 , p. $1026,2020$.

PEREIRA, A. M. et al. Assessing environmental risk of pharmaceuticals in portugal: An approach for the selection of the portuguese monitoring stations in line with directive 2013/39/eu. Chemosphere, Elsevier, v. 144, p. 2507-2515, 2016.

PINO, M. R. et al. Acute toxicological effects on the earthworm eisenia fetida of 18 common pharmaceuticals in artificial soil. Science of the Total Environment, Elsevier, v. 518, p. 225-237, 2015.

PINTADO-HERRERA, M. G. et al. Distribution, mass inventories, and ecological risk assessment of legacy and emerging contaminants in sediments from the pearl river estuary in china. Journal of hazardous materials, Elsevier, v. 323, p. 128-138, 2017.

PINTO, T. J. da S. et al. Impact of 2, 4-d and fipronil on the tropical midge Chironomus sancticaroli (diptera: Chironomidae). Ecotoxicology and Environmental Safety, Elsevier, v. 209, p. 111778, 2021.

PINTO, T. J. da S. et al. Impact of 2,4-d and fipronil on the tropical midge Chironomus sancticaroli (diptera: Chironomidae). Ecotoxicology and Environmental Safety, v. 209, p. 111778, 2021. ISSN 0147-6513. Disponível em: https://www.sciencedirect.com/ science/article/pii/S0147651320316146. 
PITTER, G. et al. Serum levels of perfluoroalkyl substances (pfas) in adolescents and young adults exposed to contaminated drinking water in the veneto region, italy: A cross-sectional study based on a health surveillance program. Environmental health perspectives, v. 128, n. 2, p. 027007, 2020.

POMPÊO, M. et al. Ecologia de reservatórios e interfaces. São Paulo: Instituto de Biociências da Universidade de São Paulo, 2015.

PORINCHU, D. F.; MACDONALD, G. M. The use and application of freshwater midges (chironomidae: Insecta: Diptera) in geographical research. Progress in Physical Geography, Sage Publications Sage CA: Thousand Oaks, CA, v. 27, n. 3, p. 378-422, 2003.

POSSETTI, R. B. Avaliação do impacto da estação de tratamento de esgoto (ETE) do município de Araraquara-SP, no manancial Ribeirão das Cruzes, pela utilização dos macroinvertebrados aquáticos como bioindicadores. 2015. Tese (Doutorado) — Universidade de São Paulo, 2015.

PRASKOVA, E. et al. Effects of subchronic exposure of diclofenac on growth, histopathological changes, and oxidative stress in zebrafish (Danio rerio). The Scientific World Journal, Hindawi, v. 2014, 2014.

PRASKOVA, E. et al. Assessment of diclofenac lc50 reference values in juvenile and embryonic stages of the zebrafish (Danio rerio). Polish journal of veterinary sciences, Polish Academy of Sciences Committee of Veterinary Sciences, 2011.

QUINTANA, R. et al. Faunistic study of chironomidae (diptera, nematocera) collected in the wastewater treatment plant of sestao (biscay, basque autonomous community) and surrounding areas. Boletín de la Asociación Española de Entomología, Asociación Española de Entomología, v. 42, n. 1/2, p. 49-69, 2018.

RA, J. S. et al. Comparative whole effluent toxicity assessment of wastewater treatment plant effluents using Daphnia magna. Bulletin of Environmental Contamination and Toxicology, Springer, v. 80, n. 3, p. 196-200, 2008.

RAPTIS, C. E.; JURASKE, R.; HELLWEG, S. Investigating the relationship between toxicity and organic sum-parameters in kraft mill effluents. Water research, Elsevier, v. 66, p. 180-189, 2014.

RAUNIO, J.; PAAVOLA, R.; MUOTKA, T. Effects of emergence phenology, taxa tolerances and taxonomic resolution on the use of the chironomid pupal exuvial technique in river biomonitoring. Freshwater Biology, Wiley Online Library, v. 52, n. 1, p. 165-176, 2007.

REBECHI-BAGGIO, D. et al. Factors that alter the biochemical biomarkers of environmental contamination in Chironomus sancticaroli (diptera, chironomidae). Revista Brasileira de Entomologia, SciELO Brasil, v. 60, p. 341-346, 2016.

REGULATIONS, U. S. E. P. A. O. of W. Technical support document for water quality-based toxics control. [S.l.: s.n.]: Office of Water Enforcement and Permits, Office of Water Regulations and ..., 1991. 
REHMAN, U. ur; KHAN, S.; MUHAMMAD, S. Ingestion of arsenic-contaminated drinking water leads to health risk and traces in human biomarkers (hair, nails, blood, and urine), pakistan. Exposure and Health, Springer, v. 12, n. 2, p. 243-254, 2020.

RICHARDI, V. S. et al. Morpho-histological characterization of immature of the bioindicator midge Chironomus sancticaroli strixino and strixino (diptera, chironomidae). Revista Brasileira de Entomologia, SciELO Brasil, v. 59, p. 240-250, 2015.

RIETHMULLER, N. et al. Effects of water hardness and alkalinity on the toxicity of uranium to a tropical freshwater hydra (Hydra viridissima). Biomarkers, Taylor \& Francis, v. 6, n. 1, p. 45-51, 2008.

RIVERA-UTRILLA, J. et al. Pharmaceuticals as emerging contaminants and their removal from water. a review. Chemosphere, Elsevier, v. 93, n. 7, p. 1268-1287, 2013.

RIZZO, L. Bioassays as a tool for evaluating advanced oxidation processes in water and wastewater treatment. Water research, Elsevier, v. 45, n. 15, p. 4311-4340, 2011.

ROCHA, O. et al. Sensitivities of three tropical indigenous freshwater invertebrates to single and mixture exposures of diuron and carbofuran and their commercial formulations. Ecotoxicology, Springer, v. 27, n. 7, p. 834-844, 2018.

RODRIGUEZ-NARVAEZ, O. M. et al. Treatment technologies for emerging contaminants in water: A review. Chemical Engineering Journal, Elsevier, v. 323, p. 361-380, 2017.

ROSA, B. J. F. V. et al. Chironomidae and oligochaeta for water quality evaluation in an urban river in southeastern brazil. Environmental monitoring and assessment, Springer, v. 186, n. 11, p. 7771-7779, 2014.

ROSAL, R. et al. Occurrence of emerging pollutants in urban wastewater and their removal through biological treatment followed by ozonation. Water research, Elsevier, v. 44 , n. 2 , p. 578-588, 2010.

ROSE, R.; WARNE, M. S. J.; LIM, R. Life history responses of the cladoceran Ceriodaphnia dubia to variation in food concentration. Hydrobiologia, Springer, v. 427, n. 1, p. 59-64, 2000.

ROSENBAUM, R. K. Ecotoxicity. In: Life cycle impact assessment. [S.l.: s.n.]: Springer, 2015. p. 139-162.

ROUX, J. L. et al. Chloramination of wastewater effluent: Toxicity and formation of disinfection byproducts. Journal of Environmental Sciences, Elsevier, v. 58, p. $135-145,2017$.

RUBINGER, C. F. Seleção de métodos biológicos para a avaliação toxicológica de efluentes industriais. Universidade Federal de Minas Gerais, 2009.

SACHER, F. et al. Pharmaceuticals in groundwaters: analytical methods and results of a monitoring program in baden-württemberg, germany. Journal of chromatography A, Elsevier, v. 938, n. 1-2, p. 199-210, 2001.

SANCHES, N. A. D. O.; GORNI, G. R. Preferência de habitat de oligochaeta (annelida, clitellata) em macrófitas aquáticas na represa ribeirão das anhumas (américo brasiliense-sp). Revista Brasileira Multidisciplinar, v. 17, n. 1, p. 165-173, 2014. 
SANTANA, M. V.; ZHANG, Q.; MIHELCIC, J. R. Influence of water quality on the embodied energy of drinking water treatment. Environmental science \& technology, ACS Publications, v. 48, n. 5, p. 3084-3091, 2014.

SANTOS, D. M. D. et al. Multiresidue determination and predicted risk assessment of contaminants of emerging concern in marine sediments from the vicinities of submarine sewage outfalls. Marine pollution bulletin, Elsevier, v. 129, n. 1, p. 299-307, 2018.

SANTOS, L. H. et al. Ecotoxicological aspects related to the presence of pharmaceuticals in the aquatic environment. Journal of hazardous materials, Elsevier, v. 175, n. 1-3, p. 45-95, 2010.

SATHISHKUMAR, P. et al. Occurrence, interactive effects and ecological risk of diclofenac in environmental compartments and biota-a review. Science of The Total Environment, Elsevier, v. 698, p. 134057, 2020.

SAVIĆ-ZDRAVKOVIĆ, D. et al. An environmentally relevant concentration of titanium dioxide (tio2) nanoparticles induces morphological changes in the mouthparts of Chironomus tentans. Chemosphere, Elsevier, v. 211, p. 489-499, 2018.

SCHERER, C. et al. Feeding type and development drive the ingestion of microplastics by freshwater invertebrates. Scientific reports, Nature Publishing Group, v. 7, n. 1, p. 1-9, 2017.

SCHEURELL, M. et al. Occurrence of diclofenac and its metabolites in surface water and effluent samples from karachi, pakistan. Chemosphere, Elsevier, v. 77, n. 6, p. 870-876, 2009.

SCHMIDT, S. et al. Liquid chromatography-tandem mass spectrometry detection of diclofenac and related compounds in water samples. Journal of Chromatography A, Elsevier, v. 1538, p. 112-116, 2018.

SILVA, A. P. S. e et al. Toxicity of carmine cochineal and caramel iv dyes to terrestrial plants and micro-crustaceans. Water, Air, \& Soil Pollution, Springer, v. 231, n. 6, p. 1-9, 2020.

SILVA, L. C. et al. Acute and chronic toxicity of 2, 4-d and fipronil formulations (individually and in mixture) to the neotropical cladoceran Ceriodaphnia silvestrii. Ecotoxicology, Springer, v. 29, n. 9, p. 1462-1475, 2020.

SILVA, P. R. da et al. Evaluation of toxicity and estrogenicity in uasb-treated municipal sewage. Chemosphere, Elsevier, v. 268, p. 128778, 2021.

SILVA, P. R. da et al. Evaluation of toxicity and estrogenicity in uasb-treated municipal sewage. Chemosphere, Elsevier, v. 268, p. 128778, 2021.

SINGH, K. P. et al. Occurrence of pharmaceuticals in urban wastewater of north indian cities and risk assessment. Environmental monitoring and assessment, Springer, v. 186, n. 10, p. 6663-6682, 2014.

SIQUEIRA, M. S. et al. Hospitalizations due to diseases associated with poor sanitation in the public health care network of the metropolitan region of porto alegre, rio grande do sul state, brazil, 2010-2014. Epidemiologia e Serviços de Saúde, SciELO Brasil, v. 26, p. 795-806, 2017. 
SIWILA, S.; BRINK, I. C. A novel low-cost multi-barrier system for drinking water treatment in rural and suburban areas. Water Practice and Technology, IWA Publishing, v. 15, n. 1, p. 48-65, 2020.

SIZMUR, T. et al. Relationships between potentially toxic elements in intertidal sediments and their bioaccumulation by benthic invertebrates. PloS one, Public Library of Science San Francisco, CA USA, v. 14, n. 9, p. e0216767, 2019.

SMAGIN, A. et al. Dependence of the osmotic pressure and electrical conductivity of soil solutions on the soil water content. Eurasian Soil Science, Springer, v. 51, n. 12, p. 1462-1473, 2018.

SMETI, E. et al. Effects of olive mill wastewater discharge on benthic biota in mediterranean streams. Environmental Pollution, Elsevier, v. 254, p. 113057, 2019.

SOUSA, D. N. R. de et al. Electrical conductivity and emerging contaminant as markers of surface freshwater contamination by wastewater. Science of the total environment, Elsevier, v. 484, p. 19-26, 2014.

SOUSA, D. N. R. de et al. Spatio-temporal evaluation of emerging contaminants and their partitioning along a brazilian watershed. Environmental Science and Pollution Research, Springer, v. 25, n. 5, p. 4607-4620, 2018.

SPONZA, D. T.; DEMIRDEN, P. Relationships between chemical oxygen demand (cod) components and toxicity in a sequential anaerobic baffled reactor/aerobic completely stirred reactor system treating kemicetine. Journal of hazardous materials, Elsevier, v. 176, n. $1-3$, p. $64-75,2010$.

STANCOVA, V. et al. Effects of mixture of pharmaceuticals on early life stages of tench (tinca tinca). BioMed research international, Hindawi, v. 2014, 2014.

STANKOVIĆ, J. et al. Exposure to a microplastic mixture is altering the life traits and is causing deformities in the non-biting midge Chironomus riparius meigen (1804). Environmental Pollution, Elsevier, v. 262, p. 114248, 2020.

STANLEY, D. Prostaglandins and other eicosanoids in insects: biological significance. Annu. Rev. Entomol., Annual Reviews, v. 51, p. 25-44, 2006.

STEPANOVA, S. et al. The effects of diclofenac on early life stages of common carp (Cyprinus carpio). Environmental Toxicology and Pharmacology, Elsevier, v. 35, n. 3, p. 454-460, 2013.

STEYN, M. et al. Treated acid mine drainage and stream recovery: Downstream impacts on benthic macroinvertebrate communities in relation to multispecies toxicity bioassays. Journal of environmental management, Elsevier, v. 235, p. 377-388, 2019.

STÜLTEN, D. et al. Occurrence of diclofenac and selected metabolites in sewage effluents. Science of the Total Environment, Elsevier, v. 405, n. 1-3, p. 310-316, 2008.

TANG, Y. et al. Contaminants of emerging concern in aquatic environment: Occurrence, monitoring, fate, and risk assessment. Water Environment Research, Wiley Online Library, v. 92, n. 10, p. 1811-1817, 2020. 
TAO, Y. et al. Effects of climate change on bioaccumulation and biomagnification of polycyclic aromatic hydrocarbons in the planktonic food web of a subtropical shallow eutrophic lake in china. Environmental Pollution, v. 223, p. 624-634, 2017. ISSN 0269-7491. Disponível em: https://www.sciencedirect.com/science/article/pii/ S026974911631394X.

TARDY, V. et al. A pilot experiment to assess the efficiency of pharmaceutical plant wastewater treatment and the decreasing effluent toxicity to periphytic biofilms. Journal of Hazardous Materials, Elsevier, v. 411, p. 125121, 2021.

TERNES, T. A. Occurrence of drugs in german sewage treatment plants and rivers. Water research, Elsevier, v. 32, n. 11, p. 3245-3260, 1998.

THOMAS, K. V. et al. Screening for selected human pharmaceuticals and cocaine in the urban streams of manaus, amazonas, brazil. JAWRA Journal of the American Water Resources Association, Wiley Online Library, v. 50, n. 2, p. 302-308, 2014.

TIMM, T.; MARTIN, P. J. Chapter 21 - clitellata: Oligochaeta. In: THORP, J. H.; ROGERS, D. C. (ed.). Thorp and Covich's Freshwater Invertebrates (Fourth Edition). Fourth edition. Boston: Academic Press, 2015. p. 529-549. ISBN 978-0-12-385026-3. Disponível em: https://www.sciencedirect.com/science/article/pii/ B9780123850263000218.

TOGOLA, A.; BUDZINSKI, H. Multi-residue analysis of pharmaceutical compounds in aqueous samples. Journal of Chromatography a, Elsevier, v. 1177, n. 1, p. 150-158, 2008.

TRIVINHO-STRIXINO, S. Estudos sobre a fecundidade de Chironomus sancarlensis sp. n.(Diptera: Chironomidae).[sl] 182 p. 1980. Tese (Doutorado) Tese (Doutorado em Ciências)-Instituto de Biociências, Universidade de São ..., 1980.

TRIVINHO-STRIXINO, S. Chironomidae (insecta, diptera, nematocera) do estado de são paulo, sudeste do brasil. Biota Neotropica, SciELO Brasil, v. 11, p. 675-684, 2011.

TRIVINHO-STRIXINO, S.; STRIXINO, G. Larvas de Chironomidae (Diptera) do Estado de São Paulo: guia de identificação e diagnose dos gêneros. [S.l.: s.n.], 1995.

TRUHAUT, R. Ecotoxicology: objectives, principles and perspectives. Ecotoxicology and environmental safety, Elsevier, v. 1, n. 2, p. 151-173, 1977.

TUFAIL, A. et al. A critical review of advanced oxidation processes for emerging trace organic contaminant degradation: Mechanisms, factors, degradation products, and effluent toxicity. Journal of Water Process Engineering, Elsevier, p. 101778, 2020.

VANNINI, A. et al. Toxicity of diclofenac in the Fern Azolla filiculoides and the Lichen Xanthoria parietina. Bulletin of environmental contamination and toxicology, Springer, v. 100, n. 3, p. 430-437, 2018.

VARSHNEY, P. et al. Biological diversity of live food spectrum at ambedkar park, a sewage dominated area in downstream of river gomti in lucknow, india. Dr PR Yadav, 2014 . 
VAZQUEZ, L. C. Unraveling a municipal effluent's toxicity to Tripneustes gratilla sperm fertilization. Environmental toxicology and chemistry, Wiley Online Library, v. 32, n. 6, p. 1382-1387, 2013.

VILLA, S. et al. Effects of a treated sewage effluent on behavioural traits in diamesa cinerella and Daphnia magna. Journal of limnology, PAGEPress Publications, v. 77, 2018.

WAISSI, G. et al. The chronic effects of fullerenec60-associated sediments in the midge Chironomus riparius-responses in the first and the second generation. Environmental Pollution, Elsevier, v. 229, p. 423-430, 2017.

WAISSI-LEINONEN, G. C. et al. Fullerenes (nc60) affect the growth and development of the sediment-dwelling invertebrate Chironomus riparius larvae. Environmental Pollution, Elsevier, v. 206, p. 17-23, 2015.

WANTZEN, K. M. et al. Invertebrates in neotropical floodplains. In: Invertebrates in freshwater wetlands. [S.l.: s.n.]: Springer, 2016. p. 493-524.

WATSON, T. Public health investments and the infant mortality gap: Evidence from federal sanitation interventions on us indian reservations. Journal of Public Economics, Elsevier, v. 90, n. 8-9, p. 1537-1560, 2006.

WOERMANN, M.; SURES, B. Ecotoxicological effects of micropollutant-loaded powdered activated carbon emitted from wastewater treatment plants on Daphnia magna. Science of The Total Environment, Elsevier, v. 746, p. 141104, 2020.

WONGLERSAK, R. et al. Insect body size changes under future warming projections: a case study of chironomidae (insecta: Diptera). Hydrobiologia, Springer, v. 848, n. 11, p. 2785-2796, 2021.

WORKAGEGN, K. B. et al. Toxicity evaluation of wastewater treatment plant of textile effluent using fish: nile tilapia Oreochromis niloticus. International Journal of Aquaculture, v. 3, 2013.

WU, C. et al. Secondary production of macrofauna in mangrove and salt marsh of zhangjiang river estuary, fujian. Journal of Xiamen University (Natural Science), v. 52, p. 259-266, 2013.

XIE, Z. et al. Combined effects of environmentally relevant concentrations of diclofenac and cadmium on Chironomus riparius larvae. Ecotoxicology and Environmental Safety, Elsevier, v. 202, p. 110906, 2020.

YANG, C. et al. Freezing/thawing pretreatment coupled with biological process of thermophilic Geobacillus sp. g1: acceleration on waste activated sludge hydrolysis and acidification. Bioresource technology, Elsevier, v. 175, p. 509-516, 2015.

YOKOTA, H. et al. Chronic exposure to diclofenac induces delayed mandibular defects in medaka (Oryzias latipes) in a sex-dependent manner. Chemosphere, Elsevier, v. 210, p. 139-146, 2018. 
YOUBI, A. et al. Potential use of morphological deformities in Chironomus spp.

(diptera: Chironomidae) as a bioindicator of heavy metals pollution in north-east algeria.

Environmental Science and Pollution Research, Springer, v. 27, n. 8, p. 8611-8620, 2020 .

YU, Y. et al. Comparative analysis of toxicity reduction of wastewater in twelve industrial park wastewater treatment plants based on battery of toxicity assays. Scientific reports, Nature Publishing Group, v. 9, n. 1, p. 1-10, 2019.

ZAGATTO, P. A.; BERTOLETTI, E. et al. Ecotoxicologia aquática: princípios e aplicações. [S.l.: s.n.]: RiMa São Carlos, 2008. v. 478.

ZAGHLOUL, A. et al. Biological indicators for pollution detection in terrestrial and aquatic ecosystems. Bulletin of the National Research Centre, SpringerOpen, v. 44, n. 1, p. 1-11, 2020.

ZATTARA, E. E.; BELY, A. E. Evolution of a novel developmental trajectory: fission is distinct from regeneration in the annelid Pristina leidyi. Evolution \& development, Wiley Online Library, v. 13, n. 1, p. 80-95, 2011.

ZHANG, Y. et al. Reduction in toxicity of wastewater from three wastewater treatment plants to alga (Scenedesmus obliquus) in northeast china. Ecotoxicology and environmental safety, Elsevier, v. 119, p. 132-139, 2015.

ZHOU, H. et al. Ecotoxicology: the history and present direction. Encyclopedia of Ecology, Elsevier Inc., v. 2, p. 1-9, 2018.

ZOCCHI, M.; SOMMARUGA, R. Microplastics modify the toxicity of glyphosate on Daphnia magna. Science of the Total Environment, Elsevier, v. 697, p. 134194, 2019.

ZOU, W. et al. The adaptations to tube-dwelling life of propsilocerus akamusi (diptera: Chironomidae) larvae and its eutrophication-tolerant mechanisms. Limnologica, Elsevier, v. 77, p. $125684,2019$.

ZWIENER, C.; FRIMMEL, F. Short-term tests with a pilot sewage plant and biofilm reactors for the biological degradation of the pharmaceutical compounds clofibric acid, ibuprofen, and diclofenac. Science of the Total Environment, Elsevier, v. 309, n. 1-3, p. 201-211, 2003. 



\section{APÊNDICES}





\section{APÊNDICE A - PARÂMETROS FÍSICO-QUÍMICOS FASE 1 - TESTE AGUDO}

Figura 42 - Parâmetros físico-químicos F1

\begin{tabular}{|c|c|c|c|c|c|c|c|c|c|c|c|c|c|}
\hline \multirow{3}{*}{$\begin{array}{l}\text { Água C. } \\
\text { Silvestrï }\end{array}$} & \multirow{3}{*}{$\begin{array}{r}\text { Parâmetros } \\
\text { Tempo } \\
\text { Controle } \\
\end{array}$} & \multicolumn{4}{|c|}{$\mathrm{PH}$} & \multicolumn{4}{|c|}{ Condutividade } & \multicolumn{4}{|c|}{ Oxigênio dissolvido } \\
\hline & & \multicolumn{2}{|c|}{ Inicial } & \multicolumn{2}{|c|}{ Final } & \multicolumn{2}{|c|}{ Inicial } & \multicolumn{2}{|c|}{ Final } & \multicolumn{2}{|c|}{ Inicial } & \multicolumn{2}{|c|}{ Final } \\
\hline & & 7,15 & 7,28 & 7,09 & 7,27 & alto & alto & alto & alto & 4,5 & 4,3 & 4 & 3,8 \\
\hline \multirow{5}{*}{ Afluente } & $6,00 \%$ & 7,2 & 7,29 & 7,07 & 7,08 & 212 & 216 & 222 & 219 & 4,3 & 4,6 & 4,7 & 4,1 \\
\hline & $12,00 \%$ & 6,87 & 7,41 & 7,15 & 7,39 & 248 & 249 & 249 & 248 & 4,7 & 4,1 & 3,8 & 3,7 \\
\hline & $25,00 \%$ & 6,96 & 7.4 & 7,26 & 7,33 & 223 & 327 & 303 & 298 & 4,8 & 4,2 & 3,9 & 3.8 \\
\hline & $50,00 \%$ & 7,39 & 7,4 & 7,85 & 7,74 & 424 & 420 & 397 & 394 & 4,3 & 4,2 & 3,1 & 3 \\
\hline & $100,00 \%$ & 7,22 & 7,32 & 7,92 & 8,07 & 783 & 785 & 752 & 768 & 1,4 & 1,2 & 1,6 & 1,4 \\
\hline \multirow{5}{*}{ Efluente } & $6,00 \%$ & 7,06 & 7,12 & 7,35 & 7,42 & 213 & 212 & 223 & 222 & 4,6 & 4,3 & 4,2 & 3,9 \\
\hline & $12,00 \%$ & 7,41 & 7,25 & 7,37 & 7,52 & 244 & 241 & 243 & 243 & 4 & 4,3 & 4 & 4,3 \\
\hline & $25,00 \%$ & 7,39 & 7,63 & 7,58 & 7,76 & 307 & 305 & 306 & 305 & 4,2 & 4,1 & 3.7 & 3.2 \\
\hline & $50,00 \%$ & 7,62 & 7,7 & 7,95 & 7,79 & 431 & 424 & 406 & 407 & 3,5 & 3,9 & 3,6 & 3,6 \\
\hline & $100,00 \%$ & 7,18 & 7,22 & 7,84 & 8,16 & 805 & 807 & 779 & 788 & 1 & 0,9 & 1,3 & 1,4 \\
\hline
\end{tabular}

\begin{tabular}{|c|c|c|c|c|c|c|c|c|c|c|c|c|c|}
\hline \multirow{3}{*}{$\begin{array}{c}\text { Água } \\
\text { bentônicos }\end{array}$} & \multirow{3}{*}{\begin{tabular}{|r} 
Parâmetros \\
Tempo \\
Controle
\end{tabular}} & \multicolumn{6}{|c|}{$\mathrm{PH}$} & \multicolumn{6}{|c|}{ Condutividade } \\
\hline & & \multicolumn{2}{|c|}{ Inicial } & \multicolumn{2}{|c|}{ Final $48 \mathrm{~h}$} & \multicolumn{2}{|c|}{ Final 96h } & \multicolumn{2}{|c|}{ Inicial } & \multicolumn{2}{|c|}{ Final $48 \mathrm{~h}$} & \multicolumn{2}{|c|}{ Final 96h } \\
\hline & & 8.25 & 7.66 & 7,43 & 7.1 & 7.01 & 6.75 & 53.1 & 49.2 & 64,4 & 63 & 78.9 & 96.1 \\
\hline \multirow{5}{*}{ Afluente } & $6,00 \%$ & 7,82 & 7,22 & 7.7 & 7,3 & 6.26 & 6,24 & 97.9 & 98.3 & 110 & 108,6 & 130,4 & 134,5 \\
\hline & $12,00 \%$ & 7,18 & 6,93 & 7,09 & 7,07 & 6.3 & 6.48 & 146,7 & 145 & 170,3 & 170,4 & 171,5 & 170,9 \\
\hline & $25,00 \%$ & 7,14 & 7,07 & 7.1 & 7,22 & 6.5 & 6.81 & 236 & 235 & 241 & 244 & 252 & 248 \\
\hline & $50,00 \%$ & 7,12 & 7,15 & 7,41 & 7,63 & 6.97 & 7.27 & 424 & 423 & 424 & 421 & 422 & 437 \\
\hline & $100,00 \%$ & 7,22 & 7,32 & 7,92 & 8,07 & 8,03 & 8,2 & 783 & 785 & 752 & 768 & 763 & 767 \\
\hline \multirow{5}{*}{ Efluente } & $6,00 \%$ & 7,13 & 6,74 & 6,77 & 6.76 & 7.61 & 7.57 & 99.7 & 105 & 105,6 & 101,6 & 173 & 181,5 \\
\hline & $12,00 \%$ & 6,93 & 6,77 & 6,77 & 6,83 & 7.32 & 7,41 & 152.1 & 152 & 159,2 & 163,2 & 161,6 & 159,2 \\
\hline & $25,00 \%$ & 6,94 & 6,93 & 6,87 & 7,08 & 7.21 & 7.24 & 245 & 240 & 248 & 248 & 270 & 264 \\
\hline & $50,00 \%$ & 7,01 & 7,08 & 7,31 & 7.53 & 7.41 & 7.44 & 433 & 434 & 426 & 430 & 436 & 439 \\
\hline & $100,00 \%$ & 7,18 & 7,22 & 7,84 & 8.16 & 7.86 & 8.05 & 805 & 807 & 779 & 788 & 766 & 767 \\
\hline
\end{tabular}

\begin{tabular}{|c|c|c|c|c|c|c|c|}
\hline \multirow{3}{*}{$\begin{array}{c}\text { Água } \\
\text { bentônicos }\end{array}$} & \multirow{3}{*}{\begin{tabular}{r|} 
Parâmetros \\
Tempo \\
Controle \\
\end{tabular}} & \multicolumn{6}{|c|}{ Oxigênio dissolvido } \\
\hline & & \multicolumn{2}{|c|}{ Inicial } & \multicolumn{2}{|c|}{ Final 48h } & \multicolumn{2}{|c|}{ Final 96h } \\
\hline & & 5,7 & 5.8 & 4.2 & 4,6 & 3.8 & 3.6 \\
\hline \multirow{5}{*}{ Afluente } & $6,00 \%$ & 8,4 & 5,2 & 2,9 & 3 & 1.2 & 2 \\
\hline & $12,00 \%$ & 4,7 & 5 & 3,1 & 3 & 1.6 & 2.1 \\
\hline & $25,00 \%$ & 4 & 4,2 & 2,6 & 3 & 1.7 & 2.4 \\
\hline & $50,00 \%$ & 3 & 2,6 & 1,9 & 2,2 & 1,5 & 1,3 \\
\hline & $100,00 \%$ & 1.4 & 1,2 & 1,6 & 1.4 & 0.5 & 0.9 \\
\hline \multirow{5}{*}{ Efluente } & $6,00 \%$ & 5 & 4,9 & 3.8 & 4 & 3 & 2.8 \\
\hline & $12,00 \%$ & 4,9 & 4.5 & 3.5 & 3,2 & 3.4 & 3.3 \\
\hline & $25,00 \%$ & 4,5 & 4,4 & 3,6 & 3.3 & 1.5 & 1.8 \\
\hline & $50,00 \%$ & 3,7 & 3.6 & 1,2 & 1,4 & 1.2 & 1.2 \\
\hline & $100,00 \%$ & 1 & 0,9 & 1,3 & 1,4 & 1,1 & 0,8 \\
\hline
\end{tabular}

$(-)=$ Indisponibilidade do aparelho

(alto) $=$ Número acima do limite de medição do aparelho 



\section{APÊNDICE B - PARÂMETROS FÍSICO-QUÍMICOS FASE 2 - TESTE AGUDO}

Figura 43 - Parâmetros físico-químicos F2

\begin{tabular}{|c|c|c|c|c|c|c|c|c|c|c|c|c|c|}
\hline \multirow{3}{*}{$\begin{array}{l}\text { Água C. } \\
\text { Silvestrii }\end{array}$} & \multirow{3}{*}{$\begin{array}{r}\text { Parâmetros } \\
\text { Tempo } \\
\text { Controle }\end{array}$} & \multicolumn{4}{|c|}{$\mathrm{PH}$} & \multicolumn{4}{|c|}{ Condutividade } & \multicolumn{4}{|c|}{ Oxigênio dissolvido } \\
\hline & & \multicolumn{2}{|c|}{ Inicial } & \multicolumn{2}{|c|}{ Final } & \multicolumn{2}{|c|}{ Inicial } & \multicolumn{2}{|c|}{ Final } & \multicolumn{2}{|c|}{ Inicial } & \multicolumn{2}{|c|}{ Final } \\
\hline & & 7,74 & 7,51 & 7,47 & 7,43 & alto & alto & alto & alto & 4,5 & 4,7 & 4,3 & 4,5 \\
\hline \multirow{5}{*}{ Afluente } & $6,00 \%$ & 6,99 & 6,83 & 6,94 & 7,1 & alto & alto & alto & alto & 4,5 & 4,5 & - & - \\
\hline & $12,00 \%$ & 7,09 & 6,98 & 7,59 & 7,61 & 239 & 241 & 230 & 234 & 4,3 & 4,4 & 4,2 & 4 \\
\hline & $25,00 \%$ & 6,87 & 6,88 & 7,37 & 7,57 & 332 & 333 & 322 & 320 & 4,1 & 4,2 & 3,9 & 3,3 \\
\hline & $50,00 \%$ & 6,89 & 6,9 & 7,92 & 7,29 & 513 & 500 & 462 & 453 & 4 & 4,2 & 2,8 & 2,7 \\
\hline & $100,00 \%$ & 7,16 & 7,12 & 7,92 & 7 & 783 & 785 & 752 & 768 & 1,4 & 1,2 & 1,6 & 1,4 \\
\hline \multirow{5}{*}{ Efluente } & $00 \%$ & 7,06 & 7,02 & 7,45 & 7,24 & alto & alto & alto & alto & 3,8 & 4 & - & - \\
\hline & $12,00 \%$ & 6,67 & 6,73 & 7,58 & 7,43 & 242 & 243 & 231 & 226 & 4,4 & 4,2 & 3,9 & 4,3 \\
\hline & $25,00 \%$ & 6,77 & 6,93 & 7,73 & 7,8 & 333 & 336 & 318 & 325 & 3,9 & 3,8 & 3,7 & 3,9 \\
\hline & $50,00 \%$ & 6,83 & 7,09 & 7,67 & 7,99 & 499 & 490 & 452 & 466 & 3 & 2,9 & 3,8 & 2,9 \\
\hline & $100,00 \%$ & 6.98 & 7,01 & 7.84 & 8.16 & 805 & 807 & 779 & 788 & 1.1 & 1 & 1.2 & 1.6 \\
\hline
\end{tabular}

\begin{tabular}{|c|c|c|c|c|c|c|c|c|c|c|c|c|c|}
\hline \multirow{3}{*}{$\begin{array}{c}\text { Ảgua } \\
\text { bentônicos }\end{array}$} & \multirow{3}{*}{$\begin{array}{r}\text { Parâmetros } \\
\text { Tempo } \\
\text { Controle }\end{array}$} & \multicolumn{6}{|c|}{$\mathrm{PH}$} & \multicolumn{6}{|c|}{ Condutividade } \\
\hline & & \multicolumn{2}{|c|}{ Inicial } & \multicolumn{2}{|c|}{ Final 48h } & \multicolumn{2}{|c|}{ Final 96h } & \multicolumn{2}{|c|}{ Inicial } & \multicolumn{2}{|c|}{ Final $48 \mathrm{~h}$} & \multicolumn{2}{|c|}{ Final 96h } \\
\hline & & 7,02 & 6,797 & 7,35 & 6,94 & 7,43 & 7,37 & 46,4 & 44,4 & 55,7 & 55 & 73 & 72 \\
\hline \multirow{5}{*}{ Afluente } & $6.00 \%$ & 7 & 6.78 & 6.88 & 6.78 & 7.25 & 7,32 & 101.3 & 98.3 & 103.3 & $\overline{103.6}$ & 121 & 115 \\
\hline & $12,00 \%$ & 6,62 & 6,67 & 6,61 & 6,69 & 7,34 & 7,41 & 154,1 & 154 & 150,3 & 146,9 & 163 & 163 \\
\hline & $25,00 \%$ & 6.24 & 6.77 & 6.76 & 6.83 & 7.56 & 7.63 & 256 & 258 & 248 & 255 & 249 & 227 \\
\hline & $50,00 \%$ & 6,78 & 6,92 & 6,88 & 7,38 & 7,87 & 8,05 & 469 & 467 & 453 & 452 & 472 & 470 \\
\hline & $100,00 \%$ & 6,12 & 6,94 & 7,92 & 8,07 & 8,18 & 8,22 & 871 & 877 & 752 & 768 & 850 & 846 \\
\hline \multirow{5}{*}{ Efluente } & $6,00 \%$ & 6.73 & 6,67 & 6.45 & 6.49 & 7.87 & 7,8 & 99.3 & 99 & 99.8 & 106,8 & 116 & 116 \\
\hline & $12,00 \%$ & 6,82 & 6,79 & 6,57 & 6,69 & 7,72 & 7,69 & 158,3 & 157 & 155,3 & 158,5 & 157 & 168 \\
\hline & $25,00 \%$ & 6.81 & 6,84 & 6.95 & 7.14 & 7.54 & 7.65 & 258 & 260 & 258 & 260 & 256 & 264 \\
\hline & $50,00 \%$ & 6,69 & 6,77 & 7,31 & 7,43 & 7,95 & 7,98 & 461 & 461 & 461 & 461 & 459 & 422 \\
\hline & $100,00 \%$ & 6.74 & 7,01 & 7.51 & 7.37 & 7.86 & 7.99 & 876 & 873 & 812 & 794 & 766 & 767 \\
\hline
\end{tabular}

\begin{tabular}{|l|r|r|r|r|r|r|r|}
\hline \multirow{3}{*}{$\begin{array}{c}\text { Agua } \\
\text { bentônicos }\end{array}$} & Parâmetros & \multicolumn{6}{|c|}{ Oxigênio dissolvido } \\
\cline { 2 - 8 } & Tempo & \multicolumn{2}{|c|}{ Inicial } & \multicolumn{2}{|c|}{ Final $48 \mathrm{~h}$} & \multicolumn{2}{|c|}{ Final 96h } \\
\cline { 2 - 8 } & Controle & 5,6 & 5,8 & 2,8 & 2,8 & 4,5 & 4 \\
\hline \multirow{4}{*}{ Afluente } & $6,00 \%$ & 4,3 & 4,1 & 2,3 & 2.1 & 4,2 & 3,6 \\
\cline { 2 - 8 } & $12,00 \%$ & 4 & 4,2 & 1,9 & 5,2 & 4 & 3,8 \\
\cline { 2 - 8 } & $25,00 \%$ & 3,9 & 3,7 & 1,9 & 1,9 & 2,1 & 3 \\
\cline { 2 - 8 } & $50,00 \%$ & 3 & 2,9 & 1,5 & 1,6 & 2,8 & 3 \\
\cline { 2 - 8 } & $100,00 \%$ & 1,7 & 1,8 & - & - & 1,6 & 1,7 \\
\hline \multirow{4}{*}{ Efluente } & $6,00 \%$ & 5,7 & 5,9 & 2,3 & 3,1 & 5 & 4,1 \\
\cline { 2 - 8 } & $12,00 \%$ & 4,8 & 5,6 & 1,8 & 1,9 & 3,5 & 3,4 \\
\cline { 2 - 8 } & $25,00 \%$ & 4,7 & 4,5 & 1,6 & 1,4 & 3,3 & 3,2 \\
\cline { 2 - 8 } & $50,00 \%$ & 4,4 & 4,5 & 1,7 & 1,9 & 2,7 & 2,8 \\
\cline { 2 - 8 } & $100,00 \%$ & 2,6 & 2,5 & 1,2 & 1,2 & 1,1 & 1,3 \\
\hline
\end{tabular}

$(-)=$ Indisponibilidade do aparelho

(alto) $=$ Número acima do limite de medição do aparelho 



\section{APÊNDICE C - PARÂMETROS FÍSICO-QUÍMICOS FASE 3 - TESTE AGUDO}

Figura 44 - Parâmetros físico-químicos F3

\begin{tabular}{|c|c|c|c|c|c|c|c|c|c|c|c|c|c|}
\hline \multirow{3}{*}{$\begin{array}{l}\text { Água } C . \\
\text { Silvestrii }\end{array}$} & \multirow{3}{*}{\begin{tabular}{|r|} 
Parâmetros \\
Tempo \\
Controle
\end{tabular}} & \multicolumn{4}{|c|}{$\mathrm{PH}$} & \multicolumn{4}{|c|}{ Condutividade } & \multicolumn{4}{|c|}{ Oxigênio/dissolvido } \\
\hline & & \multicolumn{2}{|c|}{ Inicial } & \multicolumn{2}{|c|}{ Final } & \multicolumn{2}{|c|}{ Inicial } & \multicolumn{2}{|c|}{ Final } & \multicolumn{2}{|c|}{ Inicial } & \multicolumn{2}{|c|}{ Final } \\
\hline & & - & - & - & - & - & - & - & - & - & - & - & - \\
\hline \multirow{5}{*}{ Afluente } & $6,00 \%$ & - & - & - & - & - & - & - & - & - & - & - & - \\
\hline & $12,00 \%$ & - & - & - & - & - & - & - & - & - & - & - & - \\
\hline & $25,00 \%$ & - & - & - & - & - & - & - & - & - & - & - & - \\
\hline & $50,00 \%$ & - & - & - & - & - & - & - & - & - & - & - & - \\
\hline & $100,00 \%$ & - & - & - & - & - & - & - & - & - & - & - & - \\
\hline \multirow{5}{*}{ Efluente } & $6,00 \%$ & - & - & - & - & - & - & - & - & - & - & - & - \\
\hline & $12,00 \%$ & - & - & - & - & - & - & - & - & - & - & - & - \\
\hline & $25,00 \%$ & - & - & - & - & - & - & - & - & - & - & - & - \\
\hline & $50,00 \%$ & - & - & - & - & - & - & - & - & - & - & - & - \\
\hline & $100,00 \%$ & - & - & - & - & - & - & - & - & - & - & - & - \\
\hline
\end{tabular}

\begin{tabular}{|c|c|c|c|c|c|c|c|c|c|c|c|c|c|}
\hline \multirow{3}{*}{$\begin{array}{c}\text { Ȧgua } \\
\text { bentônicos }\end{array}$} & \multirow{3}{*}{\begin{tabular}{|r|} 
Parâmetros \\
Tempo \\
Controle
\end{tabular}} & \multicolumn{6}{|c|}{$\mathrm{PH}$} & \multicolumn{6}{|c|}{ Condutividade } \\
\hline & & \multicolumn{2}{|c|}{ Inicial } & \multicolumn{2}{|c|}{ Final $48 \mathrm{~h}$} & \multicolumn{2}{|c|}{ Final 96h } & \multicolumn{2}{|c|}{ Inicial } & \multicolumn{2}{|c|}{ Final $48 \mathrm{~h}$} & \multicolumn{2}{|c|}{ Final $96 \mathrm{~h}$} \\
\hline & & 8.53 & 8 & 7,48 & 7,32 & 7,63 & 7,69 & 54 & 53 & 75 & 68 & 61 & 65 \\
\hline \multirow{5}{*}{ Afluente } & $6.00 \%$ & 7.91 & 776 & 73 & 734 & 76 & 756 & 108 & 103 & 148 & 112 & 107 & 111 \\
\hline & $12,00 \%$ & 7,74 & 7.58 & 7,32 & 7,32 & 7,4 & 7.43 & 136 & 136 & 152 & 145 & 167 & 159 \\
\hline & $25,00 \%$ & 7.39 & 7.45 & 7.3 & 7.36 & 7.34 & 7.49 & 241 & 241 & 233 & 241 & 249 & 252 \\
\hline & $50,00 \%$ & 7,43 & 7,45 & 7,4 & 7,43 & 7,6 & 7,63 & 436 & 440 & 384 & 416 & 434 & 449 \\
\hline & $100,00 \%$ & 7,41 & 7,47 & 7,23 & 7,32 & 7,5 & 7,54 & 806 & 820 & 858 & 861 & 824 & 828 \\
\hline \multirow{5}{*}{ Efluente } & $6,00 \%$ & 7.78 & 7.74 & 7.32 & 7.29 & 7.67 & 7.63 & 98 & 96 & 109 & 105 & 97 & 105 \\
\hline & $12,00 \%$ & 7,67 & 7,58 & 7,25 & 7,27 & 7,56 & 7,6 & 136 & 129 & 143 & 145 & 143 & 145 \\
\hline & $25,00 \%$ & 7,5 & 7.58 & 7.23 & 7,3 & 7.54 & 7.58 & 229 & 233 & 236 & 242 & 241 & 249 \\
\hline & $50,00 \%$ & 7,65 & 7,58 & 7,27 & 7,27 & 7,73 & 7,86 & 402 & 405 & 394 & 411 & 422 & 437 \\
\hline & $100,00 \%$ & 7.58 & 7.54 & 7.56 & 7.58 & 7.69 & 7.65 & 756 & 763 & 724 & 751 & 782 & 804 \\
\hline
\end{tabular}

\begin{tabular}{|r|r|l|l|l|l|l|l|}
\hline \multirow{3}{*}{$\begin{array}{c}\text { Ȧgua } \\
\text { bentônicos }\end{array}$} & Parâmetros & \multicolumn{6}{|c|}{ Oxigênio dissolvido } \\
\cline { 2 - 8 } & Tempo & \multicolumn{2}{|c|}{ Inicial } & \multicolumn{2}{c|}{ Final 48h } & \multicolumn{2}{c|}{ Final 96h } \\
\cline { 2 - 8 } & Controle & - & - & - & - & - & - \\
\hline \multirow{5}{*}{ Afluente } & $6,00 \%$ & - & - & - & - & - & - \\
\cline { 2 - 8 } & $12,00 \%$ & - & - & - & - & - & - \\
\cline { 2 - 8 } & $25,00 \%$ & - & - & - & - & - & - \\
\cline { 2 - 8 } & $50,00 \%$ & - & - & - & - & - & - \\
\cline { 2 - 8 } & $100,00 \%$ & - & - & - & - & - & - \\
\hline \multirow{5}{*}{ Efluente } & $6,00 \%$ & - & - & - & - & - & - \\
\cline { 2 - 8 } & $12,00 \%$ & - & - & - & - & - & - \\
\cline { 2 - 8 } & $25,00 \%$ & - & - & - & - & - & - \\
\cline { 2 - 7 } & $50,00 \%$ & - & - & - & - & - & - \\
\cline { 2 - 8 } & $100,00 \%$ & - & - & - & - & - & - \\
\hline
\end{tabular}

$(-)=$ Indisponibilidade do aparelho

(alto) $=$ Número acima do limite de medição do aparelho 



\section{APÊNDICE D - PARÂMETROS FÍSICO-QUÍMICOS FASE 1 - TESTE CRÔNICO}

Figura 45 - Parâmetros físico-químicos F1

\begin{tabular}{|c|c|c|c|c|c|c|c|c|c|c|c|c|c|}
\hline \multirow{3}{*}{$\begin{array}{c}\text { C. } \\
\text { sancticaroli }\end{array}$} & \multirow{3}{*}{$\begin{array}{r}\text { Parâmetros } \\
\text { Tempo } \\
\text { Controle } \\
\end{array}$} & \multicolumn{4}{|c|}{$\mathrm{PH}$} & \multicolumn{4}{|c|}{ Condutividade elétrica } & \multicolumn{4}{|c|}{ Oxigênio dissolvido } \\
\hline & & \multicolumn{2}{|c|}{ Inicial } & \multicolumn{2}{|c|}{ Final 96h } & \multicolumn{2}{|c|}{ Inicial } & \multicolumn{2}{|c|}{ Final 96h } & \multicolumn{2}{|c|}{ Inicial } & \multicolumn{2}{|c|}{ Final 96h } \\
\hline & & 7,15 & 6,5 & 7,89 & 7,49 & 55,5 & 48,3 & 58,5 & 68,77 & 4 & 3,9 & 3,4 & 3,3 \\
\hline \multirow{5}{*}{ Afluente } & $0,10 \%$ & 6,91 & 9,89 & 6,59 & 6,73 & 55,7 & 56,4 & 145,3 & 97,1 & 4,8 & 4,6 & 2,5 & 2,5 \\
\hline & $1,50 \%$ & 6,86 & 6,86 & 6,85 & 6,88 & 69 & 69,1 & 108,7 & 93,5 & 4,5 & 4,4 & 2,4 & 2,7 \\
\hline & $3,00 \%$ & 6,68 & 6,81 & 6,92 & 6,95 & 82,7 & 84,3 & 125,6 & 137,4 & 4,4 & 4,3 & 1 & 2 \\
\hline & $6,00 \%$ & 6,78 & 6,83 & 6,82 & 6,84 & 114,2 & 115 & 172,6 & 153,1 & 4 & 4,1 & 0,7 & 0,6 \\
\hline & $12,00 \%$ & 6,82 & 6,98 & - & - & 174,6 & 178 & - & - & 3,3 & 3,9 & - & - \\
\hline \multirow{5}{*}{ Efluente } & $0,10 \%$ & 6,2 & 6,25 & 6,94 & 6,72 & 54,1 & 54,9 & 85,6 & 72,3 & 4,2 & 4,8 & 0,7 & 0,8 \\
\hline & $1,50 \%$ & 6,19 & 6,35 & 6,58 & 6,57 & 77,4 & 67,7 & 105 & 98,3 & 4,5 & 4,8 & 0,3 & 0,5 \\
\hline & $3,00 \%$ & 6,53 & 6,54 & 6,61 & 6,67 & 81,2 & 81,9 & 111 & 106,3 & 4,4 & 4,5 & 2,2 & 1,2 \\
\hline & $6,00 \%$ & 6,66 & 6,76 & 6,76 & 6,72 & 108 & 110 & 133,2 & 127,4 & 4,8 & 4,4 & 0,7 & 0,5 \\
\hline & $12,00 \%$ & 6,81 & 6,94 & - & - & 162,7 & 165 & - & - & 4,8 & 4,6 & - & - \\
\hline
\end{tabular}

$(-)=$ Indisponibilidade de réplica 



\section{APÊNDICE E - PARÂMETROS FÍSICO-QUÍMICOS TESTES UTILIZANDO O DICLOFENACO}

Figura 46 - Parâmetros físico-químicos DCF

\begin{tabular}{|c|c|c|c|c|c|c|c|c|c|c|c|c|c|}
\hline \multirow{3}{*}{$\begin{array}{l}\text { Ceriodaphnia } \\
\text { Silvestrī }\end{array}$} & \multirow{3}{*}{$\begin{array}{r}\text { Parâmetros } \\
\text { Tempo } \\
\text { Controle }\end{array}$} & \multicolumn{4}{|c|}{$\mathrm{PH}$} & \multicolumn{4}{|c|}{ Condutividade } & \multicolumn{4}{|c|}{ Oxigênio dissolvido } \\
\hline & & \multicolumn{2}{|c|}{ Inicial } & \multicolumn{2}{|c|}{ Final } & \multicolumn{2}{|c|}{\begin{tabular}{|l|} 
Inicial \\
\end{tabular}} & \multicolumn{2}{|c|}{ Final } & \multicolumn{2}{|c|}{ Inicial } & \multicolumn{2}{|c|}{ Final } \\
\hline & & 7,61 & 7,57 & 7,38 & 7,31 & alto & alto & alto & alto & 3,9 & 4,1 & 3,7 & 3,4 \\
\hline \multirow{5}{*}{$\mathrm{DCF}(\mathrm{m} / \mathrm{L})$} & 12,00 & 7,11 & 7,11 & 7,81 & 7,66 & 152,5 & 153 & 164,4 & 169 & 4 & 3,9 & 4 & 3,6 \\
\hline & 24,00 & 7,24 & 7.2 & 7,11 & 7,16 & 150,9 & 152 & 168,1 & 165 & 4,2 & 1 & 4,3 & 4,3 \\
\hline & 36,00 & 7,34 & 7,31 & 7,21 & 7,22 & 154,7 & 155 & 158,9 & 159 & 4,3 & 4 & 4,1 & 3,8 \\
\hline & 48,00 & 7,04 & 7,08 & 7,48 & 7,23 & 158,3 & 157 & 157,3 & 158 & 4,2 & 4,1 & 3,8 & 3,7 \\
\hline & 60,00 & 7,1 & 7,11 & 7,24 & 7,25 & 158,6 & 157 & 160,3 & 162 & 4,3 & 4,1 & 3,9 & 4 \\
\hline
\end{tabular}

\begin{tabular}{|c|c|c|c|c|c|c|c|c|c|c|c|c|c|}
\hline \multirow{3}{*}{$\begin{array}{c}\text { Allonais } \\
\text { inaequalis }\end{array}$} & \multirow{3}{*}{$\begin{array}{r}\text { Parâmetros } \\
\text { Tempo } \\
\text { Controle }\end{array}$} & \multicolumn{4}{|c|}{$\mathrm{PH}$} & \multicolumn{4}{|c|}{ Condutividade } & \multicolumn{4}{|c|}{ Oxigênio dissolvido } \\
\hline & & \multicolumn{2}{|c|}{ Inicial } & \multicolumn{2}{|c|}{ Final } & \multicolumn{2}{|c|}{ Inicial } & \multicolumn{2}{|c|}{ Final } & \multicolumn{2}{|c|}{ Inicial } & \multicolumn{2}{|c|}{ Final } \\
\hline & & 7,17 & 7,53 & 7,71 & 7,67 & 53,3 & 48,8 & 63 & 68 & 4,2 & 4 & 2,6 & 2 \\
\hline \multirow{5}{*}{$\mathrm{DCF}(\mathrm{ml} / \mathrm{L})$} & 60,00 & 7,24 & 7,98 & 7,03 & 6,88 & 130,6 & 136 & 124,7 & 124 & 4,4 & & 2,9 & 3 \\
\hline & 70,00 & 6,47 & 6,34 & 7,22 & 7,13 & 63,5 & 62,6 & 81,1 & 78,5 & 4 & 4,1 & 2,8 & 2,8 \\
\hline & 80,00 & 7,65 & 7,38 & 6,89 & 6,87 & 80,1 & 67.7 & 85,5 & 81.4 & 4,2 & 4,4 & 2,9 & 2,8 \\
\hline & 90,00 & 6,24 & 6,22 & 7,97 & 7,48 & 63 & 69 & 88,4 & 84,1 & 3,8 & 3,9 & 2,9 & 2,8 \\
\hline & 100,00 & 7,43 & 7,24 & 7,27 & 7,47 & 70,7 & 20,3 & 108,4 & 120 & 3,8 & 3,8 & 2,6 & 2,8 \\
\hline
\end{tabular}

\begin{tabular}{|c|c|c|c|c|c|c|c|c|c|c|c|c|c|}
\hline \multirow{3}{*}{$\begin{array}{c}\text { Pristina } \\
\text { Longisetea }\end{array}$} & \multirow{3}{*}{$\begin{array}{r}\text { Parâmetros } \\
\text { Tempo } \\
\text { Controle }\end{array}$} & \multicolumn{4}{|c|}{$\mathrm{PH}$} & \multicolumn{4}{|c|}{ Condutividade } & \multicolumn{4}{|c|}{ Oxigênio dissolvido } \\
\hline & & \multicolumn{2}{|c|}{ Inicial } & \multicolumn{2}{|c|}{ Final } & \multicolumn{2}{|c|}{ Inicial } & \multicolumn{2}{|c|}{ Final } & \multicolumn{2}{|c|}{\begin{tabular}{l|} 
Inicial \\
\end{tabular}} & \multicolumn{2}{|c|}{ Final } \\
\hline & & 8,32 & 8,02 & 7,04 & 6,68 & 51,4 & 59,5 & 80,4 & 91,7 & 3,6 & 3,9 & 2,6 & 2 \\
\hline \multirow{5}{*}{$\mathrm{DCF}(\mathrm{m} / \mathrm{L})$} & 10,00 & 7,83 & 7,44 & 6,36 & 6,28 & 51,3 & 51,3 & 60,2 & 60,3 & 4,1 & 3,9 & 2 & 2,2 \\
\hline & 30,00 & 6,86 & 6,65 & 6,08 & 6,02 & 58,1 & 57,2 & 62,3 & 60,7 & 4 & 1 & 2,3 & 2,3 \\
\hline & 50,00 & 6,99 & 6,82 & 7,45 & 7,28 & 55,6 & 60,3 & 71,8 & 69,7 & 3,8 & 4 & 2,4 & 2,8 \\
\hline & 70,00 & 6,47 & 6,34 & 5,95 & 6,03 & 63,5 & 62.6 & 69,4 & 72,4 & 4 & 4,1 & 2,2 & 2,7 \\
\hline & 90,00 & 6,24 & 6,22 & 5,98 & 6,08 & 63 & 68 & 73,3 & 73,8 & 3,8 & 3,9 & 3,1 & 2,6 \\
\hline
\end{tabular}

\begin{tabular}{|c|c|c|c|c|c|c|c|c|c|c|c|c|c|}
\hline \multirow{3}{*}{$\begin{array}{l}\text { Chironomus } \\
\text { sancticaroli }\end{array}$} & \multirow{3}{*}{\begin{tabular}{|r|} 
Parâmetros \\
Tempo \\
Controle
\end{tabular}} & \multicolumn{4}{|c|}{$\mathrm{PH}$} & \multicolumn{4}{|c|}{ Condutividade } & \multicolumn{4}{|c|}{ Oxigênio dissolvido } \\
\hline & & \multicolumn{2}{|c|}{ Inicial } & \multicolumn{2}{|c|}{ Final } & \multicolumn{2}{|c|}{ Inicial } & \multicolumn{2}{|c|}{ Final } & \multicolumn{2}{|c|}{ Inicial } & \multicolumn{2}{|c|}{ Final } \\
\hline & & 7,17 & 7.53 & 7,71 & 7,67 & 53,3 & 48.8 & 63 & 68 & 4,2 & 4 & - & - \\
\hline \multirow{5}{*}{$\mathrm{DCF}(\mathrm{m} / \mathrm{L})$} & 0,25 & 7,08 & 6,8 & 7,34 & 7,38 & 47,6 & 46,6 & 59 & 64 & 4,5 & 4,1 & - & - \\
\hline & 0.50 & 6,51 & 6,37 & 7,25 & 7,32 & 45,7 & 47 & 67 & 64 & 4,3 & $\overline{4,1}$ & - & - \\
\hline & 1,00 & 6,07 & 6,08 & 7,28 & 7,32 & 48,6 & 46,3 & 61 & 65 & 4,3 & 4,1 & - & - \\
\hline & 2,00 & 5,98 & 6,03 & 7,27 & $\overline{7,3}$ & 46,1 & 47.4 & 59 & 68 & 4,1 & 4,1 & - & - \\
\hline & 4.00 & 6,03 & 6,07 & 7,23 & $\overline{7,3}$ & 46,2 & 475 & 68 & 67 & 3,8 & 4 & - & - \\
\hline
\end{tabular}

b) Parâmetros teste DCF - Teste toxicidade crônica

\begin{tabular}{|c|c|c|c|c|c|c|c|c|c|c|c|c|c|}
\hline \multirow{3}{*}{$\begin{array}{l}\text { Chironomus } \\
\text { sancticaroli }\end{array}$} & \multirow{2}{*}{\begin{tabular}{r|} 
Parâmetros \\
Tempo \\
\end{tabular}} & \multicolumn{4}{|c|}{$\mathrm{PH}$} & \multicolumn{4}{|c|}{ Condutividade } & \multicolumn{4}{|c|}{ Oxigênio dissolvido } \\
\hline & & \multicolumn{2}{|c|}{ Inicisl } & \multicolumn{2}{|c|}{ Final } & \multicolumn{2}{|c|}{ Inicial } & \multicolumn{2}{|c|}{ Final } & \multicolumn{2}{|c|}{ Inicial } & \multicolumn{2}{|c|}{ Final } \\
\hline & Controle & 7,55 & 7,78 & 7,64 & 7,01 & 50,9 & 46,4 & 64 & 68,7 & 4,7 & 4,5 & 4,3 & 4,2 \\
\hline \multirow{5}{*}{$\mathrm{DCF}(\mathrm{m} / \mathrm{L})$} & 1,00 & 6,36 & 6,37 & 6,81 & 6,83 & 46,3 & 46.5 & 58,4 & 59 & 4,3 & 4,4 & 4,1 & 4,3 \\
\hline & 0,50 & 6,49 & 6,47 & 6,85 & 6,89 & 46,5 & 46,7 & 57,9 & 57,8 & 4,6 & 4,4 & 4 & 3,8 \\
\hline & 0.25 & 6,59 & 6,55 & 6,78 & 6,83 & 46,2 & 46,3 & 55 & 55,2 & 4,6 & 4,2 & 4,1 & 3,7 \\
\hline & 0,13 & 6,87 & 6,74 & 6,85 & 6,87 & 48,1 & 46,5 & 59,5 & 59,5 & 4,7 & 4,5 & 4,3 & 4,4 \\
\hline & 0,10 & 7,48 & 7,11 & 6,88 & 6,85 & 45,6 & 48 & 60,3 & 60,5 & 4,2 & 4,5 & 4,5 & 4,6 \\
\hline
\end{tabular}

$(-)=$ Indisponibilidade do aparelho

(alto) $=$ Número acima do limite de mediçäo do aparelho 